\title{
Indigenous knowledge, morphological variation and genetic diversity of Kava (Piper methysticum Forst.) \\ in Merauke, Papua, Indonesia
}

\section{Dissertation}

\author{
For the award of the degree \\ Doctor rerum naturalium (Dr.rer.nat.) \\ Division of Mathematics and Natural Sciences \\ Of the Georg-August-Universitat Goettingen \\ within the Doctoral Program \\ Centre for Nature Conservation \\ Departement of Biology Conservation \\ Faculty of Biology \\ Of the Georg-August-University School of Science (GAUSS)
}

Submitted by:

Konstantina Maria Brigita Kameubun

(Born in Merauke, Papua, Indonesia)

Göttingen

2013 


\section{Thesis Committee}

Prof. Dr. Michael Muehlenberg Prof. h. c.

Centre for Nature Conservation

Prof. Dr. Reiner Finkeldey

Forest Genetics and Forest Tree Breeding, Buesgen Institute

\section{Members of the Examination Board}

Reviewer: Prof. Dr. Michael Muehlenberg Prof. h. c.

Centre for Nature Conservation

Second Reviewer: Prof. Dr. Reiner Finkeldey

Forest Genetics and Forest Tree Breeding, Buesgen Institute

\section{Futher members of the Examination Board:}

Prof. Dr. Eckhard Heymann

(Biodiversity)

Prof. Dr. Erwin Bergmeier

(Albrecht-von-Haller-Institut fuer Pflanzenwissenschaften, Biodiversity)

Prof. Dr. Rainer Willmann

Blumenbach-Institut fuer Zoologie und Anthoropologie, Biodiversity)

Prof. Dr. Marthin Ziehe

Abt. Forstgenetik und Forstpflanzenzuechtung (PEI)

Date of the oral examination: $17^{\text {th }}$ December 2013 


\section{Acknowledgments}

First of all, I would like to express my deepest gratitude to Prof. Dr. Michael Muehlenberg, for accepting me as his $\mathrm{PhD}$ candidate. Thank you very much for your confidence, helpful support, and excellent advice.

I would like to thanks Prof. Dr. Reiner Finkeldey, for consenting to be co-referee and accepting me as his student and working in his laboratorium. Thank you very much for your confidence, helpful support, and guidance throughout my research for genetic.

I would like to thanks Prof. Dr.Marthin Ziehe, Prof. Dr. Eckhard Heymann, Prof. Dr. Erwin Bergmeier, Prof. Dr. Rainer Willmann for accepting to be member of the examination board.

I am very indebted to Drs. Samuel J. Renyaan, M.Sc for introducing me to study in Goettingen, support me to inprove my knowledge and excellent advice to study and life.

I am grateful to Prof. Dr. Berth Kambuaya, Ex-President of Cenderawasih University also for Drs. Onesimus Warwer, M.Si, ex-dean of Teacher Training and Education Faculty for recommend, help, support and advise to my study. Many thanks to Dr. Nomensen S. Mambraku, Dean of Teacher Training and Education Faculty for help and support to my study.

I am grateful to Dr. rer nat Margaretha Pangau-Adam for helpful, support and advise during my study.

I am very grateful to Alexandra Dolynska for her excellent guidance in laboratory work. I am grateful to Dr. Kathleen Prinz for her guidance, advice and support throughout my research as well as during the laboratory work and writing process: Dr. Barbara Vornam, Dr. Elizabeth Gillet, who gave me enormous helps during my analysis and writing process. Many thanks to Prof. Marthin Ziehe, Dr. rer. nat. Eckhard Gottschalk for various contributions during seminars and colloquiums. Thank you for Dr. Joerg Von Wegerer for correction my English language of my dissertation and translating my summary in German.

I would also like to acknowledge Dipl.-Inf. Elisabeth Opielka, Gerold Dinkel for his help to solve computer problem. My thanks also go to Monika, Andrea 
Lambertz, Edith Strübbe secretary of Nature for Conservation, Regina Berkeley secretary of forest genetics, who always helps me with the administration matters during my study.

Thank you to Dr. Lisye Zebua for helpful analysis and sharing disccussion of morphology data.

I would like to acknowledge former students: Dr. Marius Ekue for his help from beginning to the end of my study, knowledge sharing and discussion and analyzed data ethnobotany and genetic. Dr. Essy Harnelly, $\dagger$ Dr. Sarah Seifert, Dr. Yazar Minn, Dr. Randy Villarin, FitriYola Amandita, for knowledge sharing and discussions. Thank you to all of Papuan student in Goettingen: Marlina Flassy, Dr. Hendrita Ohee, Dr. Hendrina Keiluhu and all of Indonesian student in Goettingen from 2008 to 2013 especialy for Mr.Agus Munawar, Maimun Rizal Al-Ghifary who always help me to solve my private computer problem.

Many thanks to Tante Femi Idroes who has very much help and support me to study in Goettingen. Tante Afie (Njoen Fie Koe-Werner), Tante Poppy Sopacua and Mr.Wirawan, Tante Mia and family, Tante Tini Klein and family, Tante Atit and family, Tante Nurlina, Tante Ningsih and family, Tante Tialam Hutapea,Mrs Agit Wa Ode Kambalagi - Joop family, RosyeTibuludji and Sebastian Sedel, Mr. Asigor Sitanggang, Mr. Doel and Reni Saroji, Mr. Jamauli Naibaho and Tante Jetty Hillebrecht, Mr. John Manalif and Tante Ida Siregar, Mr. Dalias and family who was prayer, help and support me.

Many thanks to all of Marind People in Marind Swamp villages are Bamol 1, Bamol 2, Iromoro, Yamuka, Kimaam, Woner, Mambum. Marind Land villages are wogikel/ Wanam, Bibikem, Yawimu, Yomop, Wasur, Yanggandur, Sota, Muting, Kumaaf, Kafgamke, Kindiki. Marind Beach villages are Wambi, Dufmira, Iwol, Makaling, Okaba, Alaku, Alatep, Sanggase, Domande, Wendu, Bahor, Urumb, Butiand Merauke in Merauke who was gave me permit to research in their area, information and sample of Wati plant.

Many thanks to Yohana Suryaningsih and all family, Brother Harry Wursok, Paul Sarkol and family, Gab Layan and family, Yohana Masela, Irma Lesomar, Hirsa Modouw, Lis Letsoin, Mr. Anton Ngili and family, Kes Karubun and family, Yaconias Maitindom and family, Mr. Paskalis Rettob and family, Joerg Richter 
and Mom (Frau Richter), Ms Verena Agustini, Dr. Agapitus Dumatubun who help and give support to me.. Thanks very much to Hengki Liuw, Viktoria Lobya, Merry Bosawer, Yudith Wanggai, Pastor Alloysius Setitit, Pastor Trismadi, Pastor Niko who help, support and prayer me.

My deepest gratitude to my $\uparrow$ Dad, Lucas Yosep Kameubun who has very support me to study, My Mom, Emerentiana Wursok for his support and prayer throughout my study. I would like to thank all of my brothers Alberthus, Bernardus, Yohanis, Emauel and sisters Maria, Adriana, Theovilla, †Viviana, Deonisia and my young sister Oliva, brothers in law, sisters in law, causins, nephews, nieces and my collegas in Biology education department of Teacher Training and Education Faculty, and also to all of my collegas in Biology department of Mathematic and Science Faculty, and to all of my colleges in Cenderawasih University, Jayapura, Papua, Indonesia.

I would like to acknowledge the Directorate General of Higher Education (DGHE) of Indonesia, Education Ministry of Indonesia for granting to me a scholarship (2008-2011)and Papua Province government.

For all of those whose names are inadvertently left out, please accept my sincere gratitude.

God blessing all of You.

Sincerely,

Goettingen, 12 November 2013

Konstantina M.B Kameubun 


\section{TABLE OF CONTENTS}

THESIS COMMITTEE

ACKNOWLEDGMENTS

ii

TABLE OF CONTENTS

iii

LIST OF FIGURES

vi

LIST OF TABLES

ix

LIST OF APPENDIX

xiv

xvii

CHAPTER 1. INTRODUCTION

1-1. The tribal groups of Marind

1-1-1. The geography and the territorial division Of the Marind

1-1-2. Faith and religion of the Marind tribe

1-1-3. The system of organization and leadership of the tribal group of the Marind.

1-2. The relation between the Marind tribes and Wati plant 6

1-3. Introductionto Wati plant

1-3-1. Taxonomy of thePiper

1-3-2. The origin and distribution of Kava

(Piper methysticum)

1-3-3. Ecology and habitat

1-3-4. Reproduction

1-3-5. Chemical effect

1-3-6. Economic value

1-4. Research Background

1-4-1. Research questions

1-4-2. The aim

1-4-3. Benefits of the research 17

1-5. Study sites

1-5-1. Location

1-5-2. Climate

1-5-3. Vegetation

1-5-4. Altitude

1-5-5. Demography

1-5-6. Livelihoods

\section{CHAPTER 2. MATERIALS AND METHODS}

2-1. Research location 23

2-2. General methods $\quad 24$

2-2-1. Method in ethnobotany study 24

2-2-2. Method in botany study / Taxonomy 25

2-2-3. Method in genetic study 26 
3-1. INDIGENOUS KNOWLEDGE OF THREE GROUPS OF MARIND TRIBE FROM MERAUKE ON THE CLASSIFICATION OF THE WATI PLANT (Piper methysticumForst.) AND THEIR UTILIZATION

3-1-1. Perceptions of the Wati plant

(Piper methysticumForst.)among the Marind tribe

3-1-2. Identification and clasification of Wati plant

3-1-3. A guide to determination of Wati according to traditional knowledge

3-1-4. Utilization of the Wati plant among the three Marind tribes

3-1-4-1. Processationof theWati plant for producing a beverage and medicine.

3-1-4-2. Use of the Wati plant in ritual ceremonies

3-1-5. Cultivation (planting, maintenance, fertilization and harvesting) of the Wati plant according to traditional knowledge

3-1-5-1. Seedbed

3-1-5-2. Planting

3-1-5-3. Fertilization

3-1-5-4. Maintenance

3-1-5-5. Harvest

3-1-6. The efforts of Preserving Wati and the culture of Wati plant in Marind tribe

3-1-7. The sales value of Wati plants

3-2. DIVERSITY STUDY OF THE WATI PLANT

(Piper methysticumForst.) FROM MERAUKE BASED

ON MORPHOLOGICAL CHARACTERISTICS

3-2-1. Morphological diversity of Wati plant.

3-2-1-1. Habitus

3-2-1-2. Root

3-2-1-3. Stem

61

3-2-1-4. Leaves

64

3-2-1-5. Inflorence

68

76

3-2-2. Description of Wati plant in botanical terms

77

3-2-3. Determination keys

83

3-2-4. Variety analysis of Wati plant morphological

88 characteristics

\section{3-3. GENETIC DIVERSITY USING}


3-4. BIOGEOGRAPHY

3-4-1. Distribution of Wati plant in Marind tribe area 107

3-4-2. Distribution of Wati plant in Papua 108

3-4-3. Distribution of Wati plant in Indonesia 109

3-4-4. Distribution of Wati plant in the world 110

\section{CHAPTER 4. DISCCUSSION}

4-1. The particular importance of Kava

(Piper methysticumForst.)intraditional ceremonies

4-2. The spreading of the classification, cultivation

and use in all cultivars

- Cultivation

- The role of weeds and harmful insects in theKava plant cultivation

- The importance of soil characteristics

- Optimum time for harvesting

- The use of Kava in other ethnis groups

- Medical use

- Use for dowry and in ceremonies

- Preservation of Kava plantations

- Marketing of Kava plants in other regions

4-3. Grouping of morphological similarities

4-4. Genetics and different morphologies in taxonomy

4-5. Genetic diversity of Kava plant in Merauke 130

1. Genetic diversity of Kava plant in Merauke130 and other polyploid plant species

2. Genetic diversity in different populations of Kava plants in Merauke

3. Clonal diversity

4. Genetic diversity as a tool for determining the status of the taxonomy of Pipermethysticum variance in Merauke

4-6. The distribution of Kava throughout the world 


\section{LIST OF FIGURES}

Figure 1-1. The map of New Guinea $\quad 1$

Figure 1-2. The distribution of the tribal groups in the regency 2 of Merauke before the splitting of the region into the three new regencies Mapi, Asmat and Boven Digul.

Figure 1-3. The map shows the sub-groups of Marind tribe area. 3

Figure 1-4. $\quad$ Cluster of sub-groups in Marind tribe, Papua. 150 Source: Wasur National Park, Merauke, 2011. (Appendix 1)

Figure 1-5. Distribution of Piper methysticum and

Piper wichimannii based on morphology, character, chemistry, and zymotypes. Source: Lebot et al. (1997).

Figure 1-6. The chemical structure of six kavalactones from Piper methysticum

Figure 1-7. Kava product on Fiji islands

Figure 1-8. The product "Thompson" produced from Kava

(Piper methysticum)

Figure 1-9. $\quad$ The product "Kava Root" (Piper methysticum) 14

Figure 1-10. Map of the regency of Merauke before and after 18 the splitting into four regencies.

Figure 1-11. The average, minimum and maximum air temperature 2007 to 2009 in the regency of Merauke.

Figure 1-12. Rainfall 2007 to 2009 in the regency of Merauke.

Figure 2-1. The map: Merauke regency after it has spreaded to 4 regencies.

Figure 3-1. Wati wrapped in banana leaves or Bus bark

Figure 3-2. Length measurement of stem internodes of the Wati plant according to three groups of Marind tribes. Category: (1) short, (2) long, (3) extra long. 
Figure 3-3. Number of local names of Wati plant which are known by the groups of Marind tribe.

Figure 3-4. Chewing and filtration of roots and stems of the Wati plant by Marind people

Figure 3-5. Chewing product from roots and stems of the Wati plant

Figure 3-6. The chewed essence from the stems

Figure 3-7. Experience by Yanuarius Gebze from Wasur village

(Marind Land/Marind Darat/degh). He used the stem of the Wati plant to cure the dammages caused by motorcycle exhaust gases

Figure 3-8. The cup for the Wati beverage

(Marind language: Manggon) is made from a coconut shell.

Figure 3-9. Wati gardens can be seen from the distance.

This garden is surrounded by decorational plants

Figure 3-10. Wati garden seen from close up

Figure 3-11. Planting position of Wati; (A). oblique (B). vertical according to Marind Swamp (Marind Rawa) people

Figure 3-12. Planting position of Wati; (A). vertical, (B). oblique, (C) transversal according to Marind Beach (Marind Pantai) and Marind Land (Marind Darat) people

Figure 3-13. Covering with dry Alang-alang (Impereta cylindrica) leaves is the plantation method of Marind Land (Marind Darat / Marind degh) and Marind Beach (Marind Pantai / Marind dufh) people

Figure 3-14. The soil or mud where they plant Wati is protected with dry grass, as done by Marind Swamp (Marind Rawa / Marind bob) people

Figure 3-15. "Para-para" is a sheltered lot of Wati plants of people of Marind Swamp (Marind Rawa)

Figure 3-16. "Para-para" is a sheltered lot of Wati plants by people of Marind Beach (Marind Pantai) and Marind Land (Marind Darat) 
Figure 3-17. "Rumah anakan" is a sheltered lot of recent Wati plants made of Alang-alang grass (Imperata cylindrica) by people of Marind Swamp (Marind Rawa)

Figure 3-18. Harvesting of Wati plant

Figure 3-19. Wrapping up a Wati plant to be brought from the garden to the house

Figure 3-20. Wati plant wrapped up and ready to be brought home

Figure 3-21. Planting Wati in their house yards in a bed by people in the central area of Merauke

Figure 3-22. Planting Wati in their house yards, using plastic bags by people from the central Merauke area

Figure 3-23. A small cluster of Wati plant

Figure 3-24. A big cluster of Wati plant

Figure 3-25. Bunches of cut stem and roots of Wati plants

Figure 3-26. Wati roots from the shrub habitus

Figure 3-27. Cross-section of Wati roots from the shrub habitus, $(40 \times 2,5)$

Figure 3-28. Categorization of stem color: black, brown, and red in short stem internodes (A) and long internodes (B)

Figure 3-29. Categorization of color of green stem for long internodes: (A) short; (B) long; (C) very long

Figure 3-30. Stem categorization. (A) densely spotted; (B) any or only few spots

Figure 3-31. Cross-section of a Wati plant of the shrub habitus, $(40 \times 4)$

Figure 3-32. Cross-section of a Wati stem of the shrub habitus with a green stem yielded by freeze method. Yellow cell oil can be seen

Figure 3-33. Stipula from the shrub habitus, Piper methysticum cultivar Palima

Figure 3-34. Stipula from the small tree habitus, Piper wichimannii 
Figure 3-35. Diversity of the leaf color in the Wati plant in Merauke

(A). green (B). dark green (C). goldish-yellow green.

Figure 3-36. Cross-section of a Wati plant leaf of the shrub habitus (red stem and long internode (40 x 2.5) using the paraffin method

Figure 3-37. Trichoma in a cross-section of a Wati leaf of the shrub habitus with a green stem by using the freeze method

Figure 3-38. Trichoma in a slice from the leaf veins of a Wati plant of the shrub habitus $(20 \times 2,5)$ using the paraffin method

Figure 3-39. Trichoma in a cross-section of a Piper gibilimbum leaf of the shrub habitus with a green stem by using the freeze method

Figure 3-40. Stomata in a paradermal incision of the upper surface of a Wati plant leaf $(40 \times 2.5)$ using the paraffin method

Figure 3-41. Inflorescence on a shrub habitus, brownish red stem, 76 long internode, Piper methysticum cultivar Palima

Figure 3-42. Inflorescence on a small tree habitus, green stem, very long internode, Piper wichimannii

Figure 3-43. cultivar Wati Kuning

$\begin{array}{lll}\text { Figure 3-44. } & \text { cultivar Safurawe } & 78\end{array}$

$\begin{array}{lll}\text { Figure 3-45. cultivar Munana } & 79\end{array}$

$\begin{array}{llr}\text { Figure 3-46. cultivar Palima } & 80\end{array}$

$\begin{array}{lll}\text { Figure 3-47. cultivar Babid } & 81\end{array}$

$\begin{array}{llr}\text { Figure 3-48. Piper wichimannii } & 82\end{array}$

Figure 3-49. Dendogram of morphological similarity of the Wati plant 89 (Piper wichimannii and Piper methysticum and its cultivars). Cluster analysis with Statistica 8.0

Figure 3-50. Dendogram of morphological similarity of the Wati plant 90 (Piper wichimannii and Piper methysticum) and their cultivars of the result of the cluster analysis using NTSYSpc 2.02i. Explanations: PWIC $=$ Piper wichimannii, $\mathrm{PSF}=$ =Piper methysticum $\mathrm{cv}$ Safurawe, 
PPlm= Piper methysticum

cv Palima, PBbd= Piper methysticum cv Babid,

$\mathrm{PWku}=$ Piper methysticum cv Wati Kuning,

PMnn= Piper methysticum cv Munana.

Figure 3-51. Plot of the score of the main components of the Wati plant 92

(Piper wichimannii and Piper methysticum cultivar of

Safurawe, Munana, Palima, Wati Kuning, and Babid).

Figure 3-52. The fragment frequency of 3 nSSRs loci in

Piper methysticum, Piper wichimnnii and Piper betle.

Figure 3-53. The total number of fragments based on species and populations on $3 \mathrm{nSSRs}$ locus.

Figure 3-54. The number of fragments for each species per locus and population.

Figure 3-55. The fragment frequency within species per locus and population at $3 \mathrm{nSSRs}$ loci.

Figure 3-56. Distribution of the different haplotypes within the different species.

Figure 3-57. Distribution of haplotypes within species and populations.

Figure 3-58. Number of clonal structures based the combination of nSSRs and cpSSRs from Piper methysticum,

$P$. wichimannii and P. betle species in Marind Beach, Marind Land and Marind Swamp.

Figure 3-59. Distribution of Wati plant in Papua/ Irian Jaya based on herbarium specimen data $: \mathbf{q}=$ the location of Wati plant.

Figure 3-60. Distribution of Wati plant in Indonesia based on herbarium specimen data. $\square=$ location of Wati plant founded.

Figure 3-61. Ditribution of Wati plant (Piper methysticum and Piper wichimannii) in the world.

Figure 3-62. Distribution of Wati plant in Malayo-Oceania region.

Sumber Kameubun, 2003.

Figure 4-1. Cultivation technique in Vanuatu (Diagram 4.1; picture by

L. Lindstrom from book written by Lebot, et al 1997). 


\section{LIST OF TABLE}

Tabel 1-1. The chemical compound using ethanol reagent, hecsana and chloroform from stem of Wati plant by tecnic GCMS (Gas Chromotography Mass Spectrometry).

Table 1-2. The chemical compound using ethanol reagent, hecsana and chloroform from leaf of Wati plant by tecnic GCMS (Gas Chromotography Mass Spectrometry). appendix 2.

Table 1-3. Chemical composition of substances per 100 grams ingredients of dry Wati.

Table 1-4. Altitude of some towns by district, data 2009

Table 1-5. Name of district, capital district and name of villages/wards of Merauke regency

Table 2-1. The total number of Piper sample in 3 populations Marind tribes in Merauke.

Table 2-2. The list of SSR primer used in the research

Table 2-3. Transferabilty of SSR primer to Piper methysticum, P. wichimannii, and P. betle.

Table 2-4. Allele sizes of nuclear and chloroplast microsatellite markers

Table 3-1. Traditional knowledge of 3 groups of the Marind tribe in Merauke, Papua

Table 3-2. Identification of parts of Wati plant by Marind Swamp (Marind Rawa / Marind bob). Appendix 5

Table 3-3. Identification of parts of Wati plant by Marind Beach. 160 Appendix 5

Table 3-4. Identification of parts of Wati plant by Marind Land. Appendix 5

Table 3-5. The local name of Wati according to Marind Land

(Marind Darat / Marind degh), Marind Beach

(Marind Pantai / Marind duft), Marind Swamp

(Marind Rawa / Marind bob). Appendix 5 
Table 3-6. The number of local names and plantation of Wati which are known by the respective group of Marind people.

Table 3-7. The parts of Wati used and processed for beverage and medicine.

Table 3-8. Characteristics of Piper wichimannii and Piper methysticum species and cultivars of Piper methysticum.

Table 3-9. Classification of local names of the Wati plant based 85 on Botanical scientific names and distibution of these cultivars in Marind Land (Marind Darat / Marind degh), Marind Swamp (Marind Rawa / Marind bob), and Marind Beach (Marind Pantai / Marind dufh) areas.

Table 3-10. Morphological characteristics of a matrix variable (qualitative) and non-matrix variable (quantitative) of the Wati plant in the Marind tribe area.

Table 3-11. Morphology character scoring of Wati plant (Appendix 7)

Table 3-12. Main component analysis of the Wati plant

(Piper wichimannii and Piper methysticum) from Merauke based on matrix variables (qualitative features) and non-matrix variables (quantitative features).

Table 3-13. Characteristics of nuclear microsatellite markers and one chloroplast marker of Piper methysticum cultivars, P. wichimannii and P. betle sampled in Marind tribe area.

Table 3-14. Characteristics of nuclear microsatellite markers and one chloroplast marker of different Piper species sampled in Marind tribe area.

Table 3-15. The generated alleles of 3 nuclear microsatellites (nSSRs) and chloroplast microsatellite markers (cpSSRs). (Appendix 8)

Table 3-16. Distribution of the clonal structures in Piper methysticum, Piper wichimannii, and Piper betle within the 3 analysed populations.

Table 3-17. Ranking of clonal structures in Piper methysticum, $P$. wichimannii and $P$. betle based on nSSRs and cpSSRs (PN B5, PN D10, PN G11 and ccmp2) in the populations of Marind Beach, Marind Land and Marind Swamp. 
Table 3-18. Composition of the clonal structures in Piper methysticum, 168 Piper wichimannii, and Piper betle based on the combination of fragment sizes of nSSR- and cpSSR- markers.

Table 3-19. Herbarium specimen of Piper methysticum collection, the 2009's and 2010 data. (Appendix 9)

Table 3-20. Herbarium specimen of Piper wichimannii collection, 2009's and 2010 data

Table 3-21. Distribution of Piper methysticum and Piper wichimannii in Marind tribe area.

Tabel 4-11. Cultivar names of Piper methysticum Forst. 


\section{LIST OF APPENDIX}

Appendix 1. Figure 1-4. Cluster of sub-groups in Marind tribe, Papua.

Source: Wasur National Park, Merauke, 2011.

Appendix 2. Tabel 1-1. The chemical compound using ethanol reagent, hecsana and chloroform from stem of Wati plant by tecnic GCMS (Gas Chromotography Mass Spectrometry).

Table 1-2. The chemical compound using ethanol reagent, 152 hecsana and chloroform from leaf of Wati plant by tecnic GCMS (Gas Chromotography Mass Spectrometry).

Appendix 3. Tabel 1-4. Altitude of some towns by district, data 2009.

153

Table 1-5. Names of District, Capital District and Name of 153 Villages/Wards of Merauke Regency.

Appendix 4. Questionnaire

Appendix 5. Table 3-2. Identification of parts of Wati plant by Marind Swamp (Marind Rawa / Marind bob).

Table 3-3. Identification of parts of Wati plant by Marind Beach

160

Table 3-4. Identification of parts of Wati plant by Marind Land

Table 3-5. The local name of Wati according to

Marind Land (Marind Darat / Marind degh), Marind Beach (Marind Pantai /Marind duft), Marind Swamp (Marind Rawa / Marind bob).

Appendix 6. Table 3-11. Morphology character scoring of Wati plant

Appendix 7. Table 3-15. The generated alleles of 3 nuclear microsatellites (nSSRs) and chloroplast microsatellite markers (cpSSRs).

Table 3-18. Composition of the clonal structures in Piper methysticum, Piper wichimannii, and Piper betle based on the combination of fragment sizes of nSSR- and cpSSR- markers.

Appendix 8. Herbarium specimen data 169

Table 3-19. Herbarium specimen of Piper methysticum collection, the 2009's and 2010 data 
Table 3-20. Herbarium specimen of Piper wichimannii collection, 2009's and 2010 data

Appendix 9. Table 4-1. The value products of Kava (Piper methysticum) 


\section{Chapter 1. INTRODUCTION}

\subsection{The tribal groups of the Marind}

\subsubsection{The geography and the territorial division of the Marind}

The Marind are one ethnic group from Melanesia race living on the island of New Guinea. In administrative terms they live in the regency of Merauke regency, province of Papua, Indonesia (Figure 1-1).

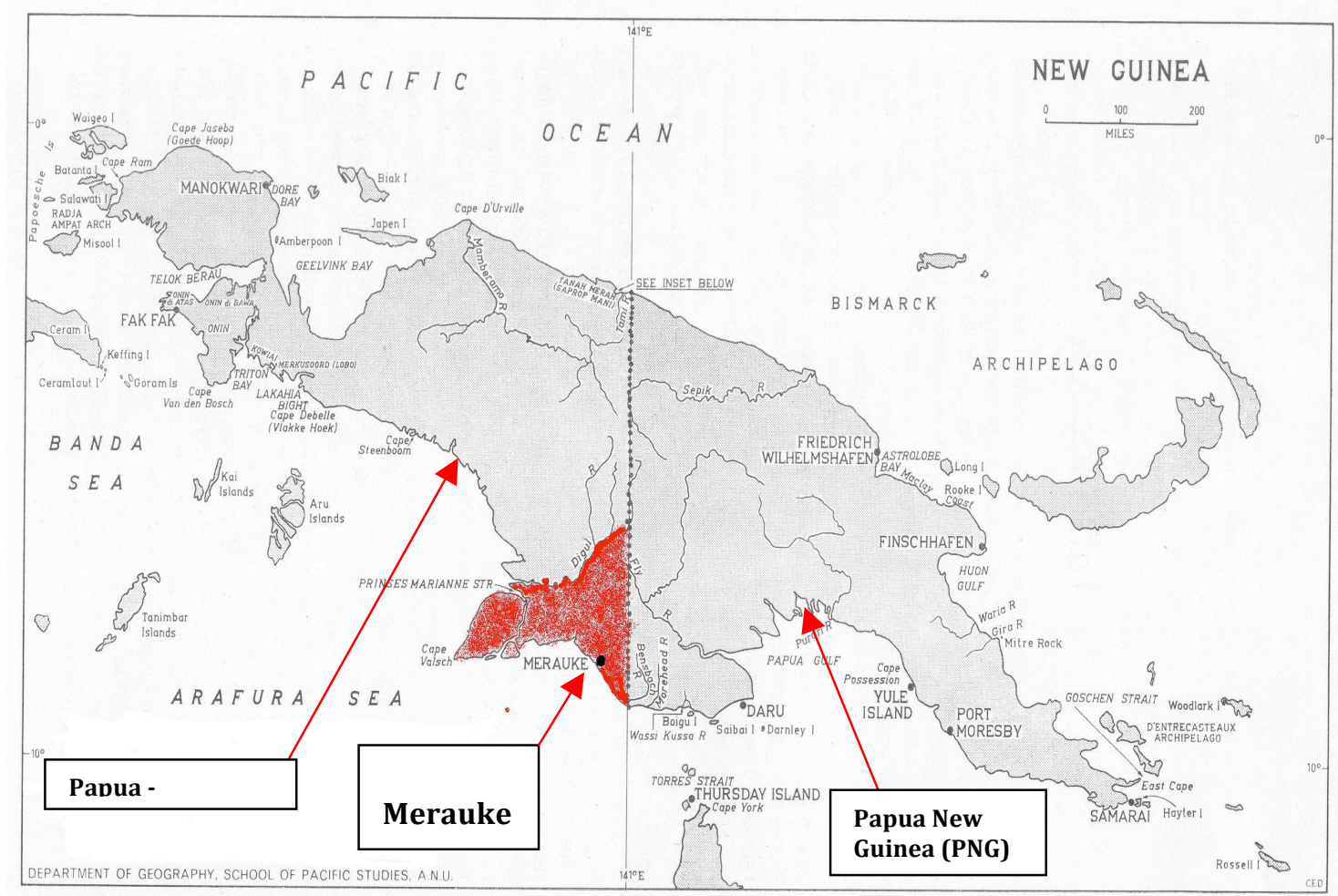

Figure 1-1. The map of New Guinea. Source: Google

The Marind are one of approximately 250 ethnic groups in Papua (CI, 1999) residing in the southern coastal area of Papua. These ethnic groups are distributed all over the coastal area from the mouth of the Digul River, Yos Sudarso Island, from the remote areas to the headwaters of River Maro, Kumbe, Bian, Bulaka and to the Fly River and to the boarder of Papua New Guinea (PNG) (Figure 1-2). 
The name Marind is derived from the word "Malind". In the Malind language Anim means person or human being. So the term became Marind Anim after a change of intonation. The Marind people name themselves Marind Anim meaning Marind persons or Marind human beings while straight haired people or strangers are named Pu-Anim. In the daily conversation among them, they often call themselves with different terms according to the range of their groups. People living in the headwaters of Maro River call themselves Jee (Yee) - Anim or Jee (Yee) person, along the coast from the mouth of Maro river to the one of Digul River name themselves Makleuw-Anim or Makleuw person, and in the east of Merauke city name themselves Kanum-Anim or Kanum person.

The distribution of the group directly influences the differences the dialects of the language. Nevertheless, they do not face a serious difficulty in communicating because differences can be found only on the dialectal level (Warip, 2000).

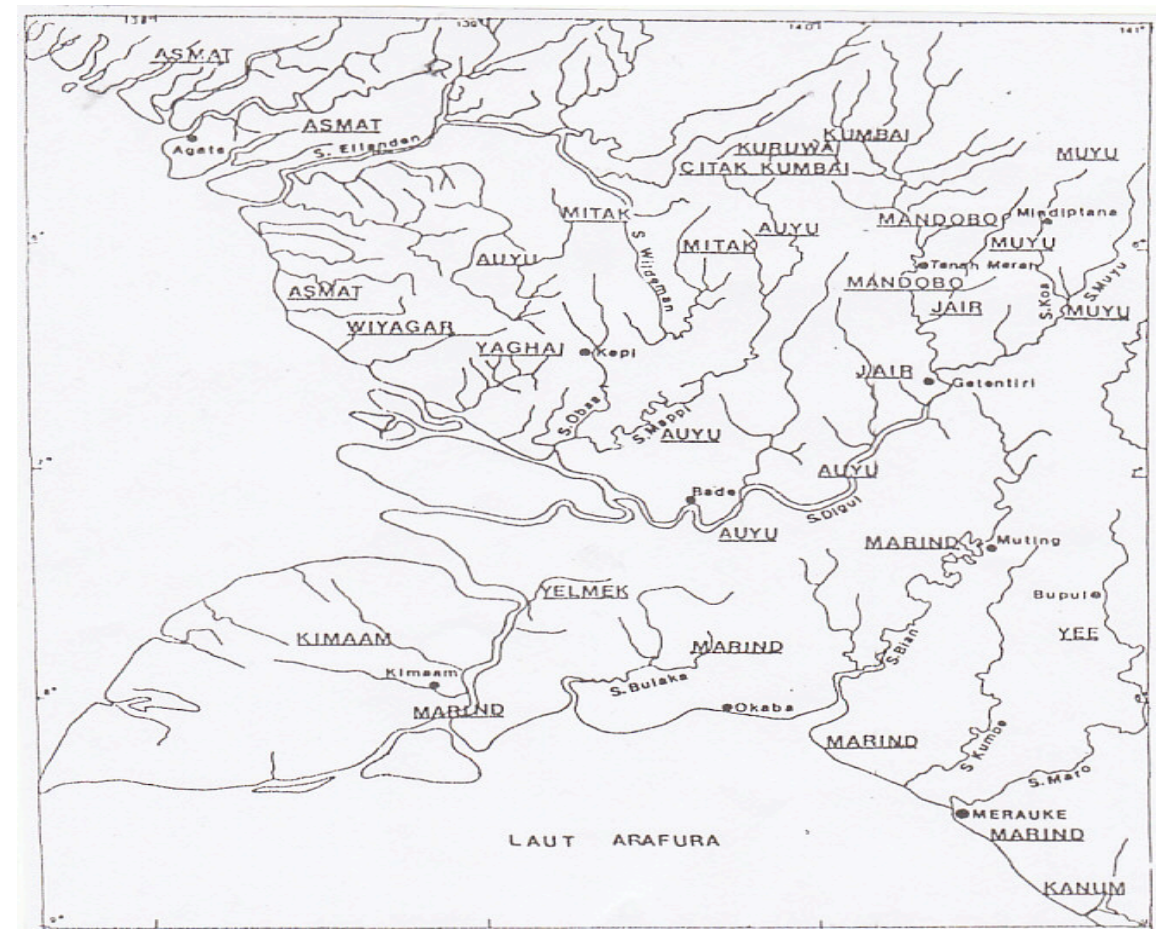

Figure 1-2. The distribution of the tribal groups in the regency of Merauke before the splitting of the region into the three new regencies Mapi, Asmat and Boven Digul. Source: Overweel, 1990. 
The so-called Marind Anim are the largest tribe among the Marind people. The Marind tribe is divided into several subtribes such as the Malind Muli Anim, Malind Kolepom Banim and Malind Sendawi. These three groups of the Marind tribe are divided further into sub-subtribes. These sub-groups of the Marind are shown and listed in Figure 1-3 and Figure 1-4 (in Appendix 1).

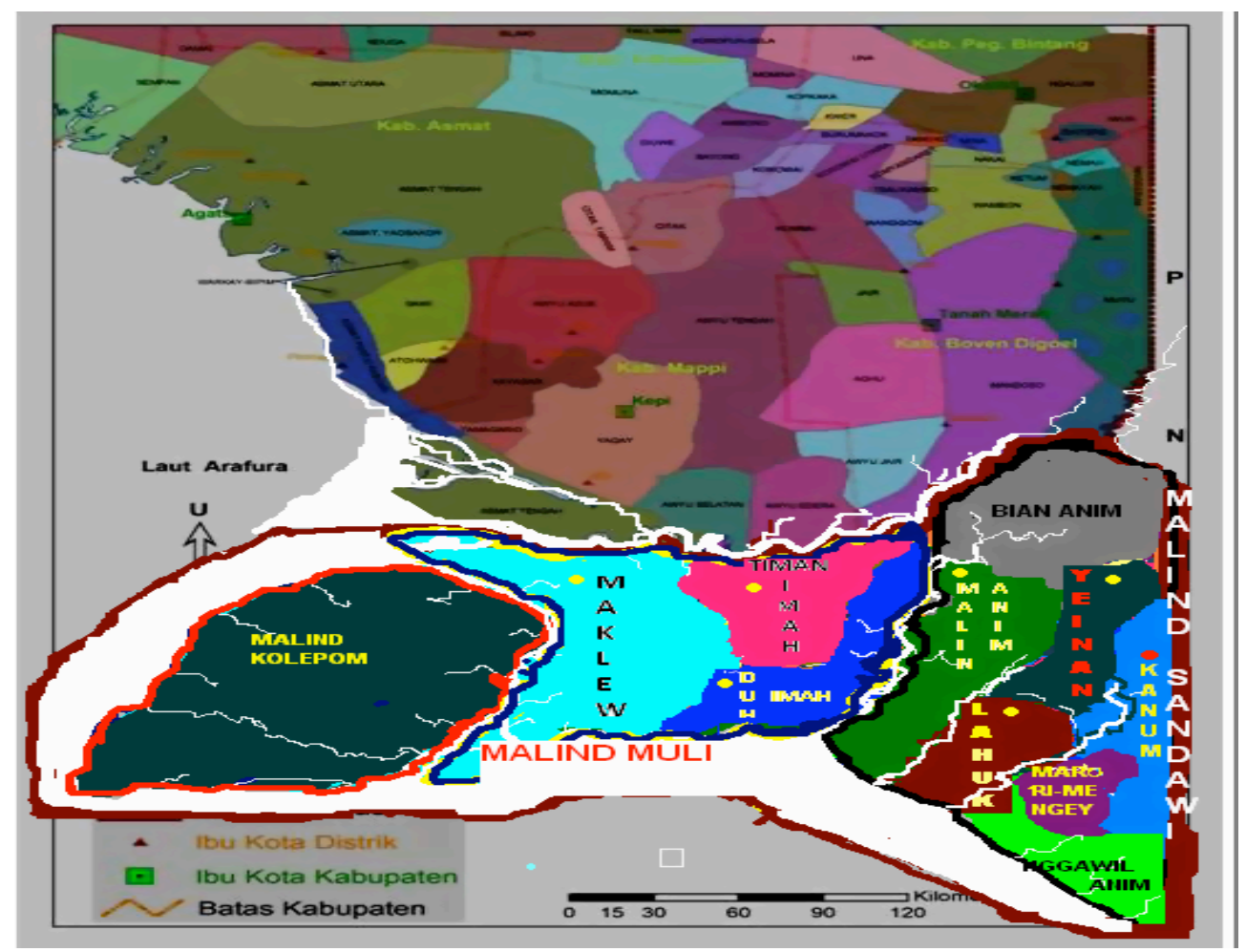

Figure 1-3. The map shows the sub-groups of Marind tribe area.

Boellars (1986) divides the Marind territory into two parts: The coastal area Marind Beach (Marind Pantai / Marind duft) and the shore area Marind Land (Marind Darat / Marind degh). This division is exclusively based on the different means of livelihood and natural resources supporting the daily life. For example, the people in Marind Beach (Marind Pantai / Marind duft) are more orientated towards the sea catching fish and shrimps as well as processing coconuts. On the contrary, people in Marind degh rely on sago and hunt kangaroos, deer and pigs (Kameubun, 2003) presents the territories of the Marind people according to their 
own notion. This division is based on the location of the area condition. The region of Marind society near the coast is called Marind Beach (Marind Pantai / Marind dufh or Malind Muli Anim). The region in the far backland of the coast is called Marind Land (Marind Darat / Marind degh or Malind Sendawi), and the boggy part of the region is called Marind Swamp (Marind Rawa / Marind bob or Marind Kolepom Banim).

\section{1-1-2. Faith and religion of the Marind tribe}

According to Overweel (1990), the ethnic group of the Marinds has four kinds of faith. Marind people in the headwaters of the Bian River have a special initiation faith called "Ezam-uzum". There are three kinds of faith on the beach such as "Maya", "Rapa", and "Imoh". "Mayo" is the most influential of them. Most of the Marind people living there profess it. "Rapa" is common in the Kondo area. "Imoh" is professed by people living not only in the village of Sanggase and Alatep but also in all remote villages using the Sanggase dialect. This faith has more adherents than "Rapa". These four kinds of faith are the aboriginal civilization that has come down on them from their own ancestors (Van Baal, 1966).

In the years after 1905 missionaries from the Hati Kudus congregation of the Dutch diocese for New Guinea in Langgur, Kai archipelago, came for the first time to Merauke (Rawung, 2005). In consequence the people of Marind tribe changed their belief and became catholic. In 1930, the protestant religion entered the Merauke area so that a number of people from the Marind tribe became protestants.

The assignment of Irian Jaya (now called Papua) to the Indonesian Republic marks the beginning of a great tide of new arrivals from other Indonesian islands. The first people who arrived mostly occupied governmental positions. After 1969, there was a larger immigration from South Sulawesi and South East Sulawesi, Buton Bugis and Makassar. In 1977 Irian Jaya (Papua) was appointed to be the greatest receiver area of the governmental program 
"transmigration". Transmigration is a government program that aims at increasing the spread of the population and of workers, the opening and expansion of new production areas and agriculture in the framework of area construction. Most of the transmigrants are from Java. The program is intended to insure the increase of the living standard of the transmigrated and the local people (Swasono and Masri 1986).

The effect of this program resulted in large settlement in the area consisting of people from Java and then from NTT (Nusa Tenggara Timur) (Overweel, 1990). The existence of transmigrants causes an increasing number in population and ethnic groups. So the population in the twenty areas of the group of Marind Land (Marind Darat / Marind degh), Marind Beach (Marind Pantai / Marind duft) and Marind Swamp (Marind Rawa / Marind bob) in the regency of Merauke has heterogeneous characteristics. One phenomenon is the intermarriage between the Marind society and people from other ethnic groups having a different religion such as Islam. Now some Marind people profess Islam.

\section{1-1-3. The system of organization and leadership of the tribal group of the Marind.}

The organization of leadership among the Marind is based on the social system and clan structure. The clan system is the most important social unit in the community structure of the Marind people. The system highly influences the relationship among all societies of the Marind-Anim. Every clan is divided into sub-clans. The term used by the Marind people to mention clan, sub-clan and a part of a sub-clan is "boan" (clan system). Every clan or "boan" in a village has a clan head or "boan leader". At present, there is an organizational structural alteration underway. Every clan is guided by a head of the ethnic group. A head of the ethnic group is appointed to lead a clan or "boan" in the village. The system and the structure of the social community of the village are based on the village system with a leadership under a village head, always in accordance with the respective settlement or residence. 
Now, the Indonesian government formed the Tradition Institute, in Bahasa Indonesia "Lembaga Adat". The Tradition Institute has a head who is called "Ketua adat" or "Kepala Adat". The Tradition Institute is part of the community social structure. It was formed by the government to support the government officials in the villages to handle community problems related to the tradition of the Marind tribe. Another objective is to motivate the Marind people to participate in the village developing program (Renwarin, 1996).

\section{1-2. The relation between the Marind tribes and Wati plant}

One tradition in the social interaction among the individuals between different groups of the Marind tribe community consists in the use of a plant which has the local name "Wati". A wati plant is a Piper species which is used by the Marind tribal people in the Merauke regency in their ritual traditions. An interesting issue about this plant is that it becomes part of the dowry for Marind tribe women. This plant is usually processed as a beverage. If drunk, this beverage will cause muscle relaxation, vision blurring and sleep prolongation. This beverage has to be available in every customary ceremony of the ethnic group of the Marind. Without this plant the ceremony can't be carried out. The drink is prepared from the root and the stem of the Wati plant. It is drunk together during the ceremony. The society of the ethnic group of the Marind also uses it as medicine.

\section{1-3. Introduction to Wati}

The name Wati is the general term used in all Marind societies. However, the Wati plant has more specific local names for its prevailing variations. The variations of the Wati plant in the ethnic group of the Marind are varietas but because the plant is cultivatied they will be called cultivars. A cultivar is a taxonomic class derived from the species (Kameubun, 2003). The scientific name of this plant is Piper methysticum Forst. 
The variety of the Wati plant in Merauke is based on morphological and anatomical features. It comprises four cultivars, namely Babid, Palima, Safurawe, and Marub (Kameubun, 2003). In Fiji there are 12 cultivars, Tonga has 9 cultivars, Vanuatu 10 cultivars and in Samoa there are 4 cultivars (Davis and J.F Brown, 1999).

Piper methysticum was described for the first time by George Foster in 1786. The first publication was in Index Kewensis, Flora Plantarum Esculentum, page number 76 (Jackson, 1895). Synonyms for Piper methysticum Forst are Macropiper methysticum (G.Forster) Hooker \& Arnott (1840) and Macropiper latifolium Miquel (1847) (Onwueme, 2000).

The local names are Wati among the Marind tribe (Heyne, 1987), Kava (Pacific islands), Ava (Samoa), Yangona (Yagona, Fiji) (Burkil, 1935); in Indonesia: Waghi, Wati, Bari (Papua); in Papua New Guinea (PNG): Koniak, Keu, Oyo (Onwueme, 2000).

A survey on the ecogeography of the isosyme variations of Piper methysticum, Piper wichimannni and Piper gibbilimbum shows that Kava probably constitutes a domesticatied form on a very narrow genetic base. It seems to be a human creation of a crop with little genetic variation. Apparenty it was created 2500 - 3000 years ago. The cultivars of Kava are sterile and are reproduced vegetatively by cutting stems. The three Piper species are decaploid with $2 \mathrm{n}=10 \mathrm{x}=130$ chromosomes. The sterility is possibly caused by the high ploidy level and the accumulation of inhibiting sexual mutations for cultivars (Lebot and Joel L, 1996; Lebot et al., 1997; Applequest and Lebot, 2006).

\section{1-3-1. Taxonomy of Piper}

Kingdom : Plantae

Divisio : Magnoliophyta

Class : : Magnoliopsida

Ordo : Piperales

Family : Piperaceae

Genus $\quad$ : Macropiper, Manekia, Peperomia, Piper, Trianacopiper, Zippelia

In the plant kingdom, Piper methysticum Forst belongs to the family of the Piperaceae. This "Pepper" family consists of about 10-12 genera. The most well- 
known genera are Peperomia and Piper (Lawrence, 1957). The distribution of the Piperaceae family peaks worldwide in tropical and subtropical regions where they often colonize forest clearings. Macropiper is confined to the South Pacific, Zippelia to Southeast Asia. Life forms of Piperaceae are trees, shrubs, lianas, herbs and with spicate inflorescences (Heywood et al., 2007). Generally, all plants from the genus Piper have an aromatic smell. The basic chromosome numbers are for Piper X=13, Peperomia X=11, Macropiper X=13, Zippelia X=19 (Kubitzki et al., 1993). There are some known economic uses of Piperaceae species: Piper nigrum is the source of commercial peppercorns; P. betle leaves are used to wrap betel nuts (Areca catechu); species of Piper and Macropiper are used in local medicine or as infusions; some species of Peperomia are grown as ornamental plants (Heywood et al., 2007).

According to Jaramillo (2006), Piper is an old genus. Backer and Bakhuizen (1963) stated that this genus is a large group and the most important one in the Piperaceae family. Jaramillo et al. (2008) said that Piper is the most important genus economically and ecologically. The genus Piper comprises plants of herbal habitus, bush and small wood. Commonly, this plant grows in wet tropical forest all over the world.

According to Backer and Bakhuizen (1963), almost 3000 species of Piper are found in tropic and subtropic areas. More than 108 species are from the Indian subcontinent. Several species among them are found in Indonesia, for example on Java 77 species are known. Paijmans (1976) said that in New Guinea two species are found. Jaramillo et al. (2008) stated that the genus Piper has ca. 2000 species.

The single areas in Papua where Piper was collected are Jayapura, Merauke, Mamberamo, Wamena, and Raja Ampat, resulting in records of about 18 species. Nine out of the 18 species are introduced and not native. All the 18 species of the Piper are used by native people of Papua as medicine, foodstuff, dowry, drink, spice and decoration plant. One species is known as bird food (Kameubun and Muehlenberg, 2009). 


\section{1-3-2. The origin and distribution of Kava (Piper methysticum)}

The origin of Kava (Piper methysticum) hasn't been identified yet unambiguously. Lebot et al. (1997) suggested that the centre of origin of Kava cultivar (Piper methysticum) is in Vanuatu, a South Pacific island state. Onwueme (2000) said that Piper methysticum is expected to come from Vanuatu. This may be true because there is a higher diversity of this plant than on other islands.

Lebot et al. (1997) describe the distribution flow of Wati plant cultivars of Piper methysticum and of Piper wichimannii based on morphologial characteristics, chemistry and zymotypes (Figure 1-5).

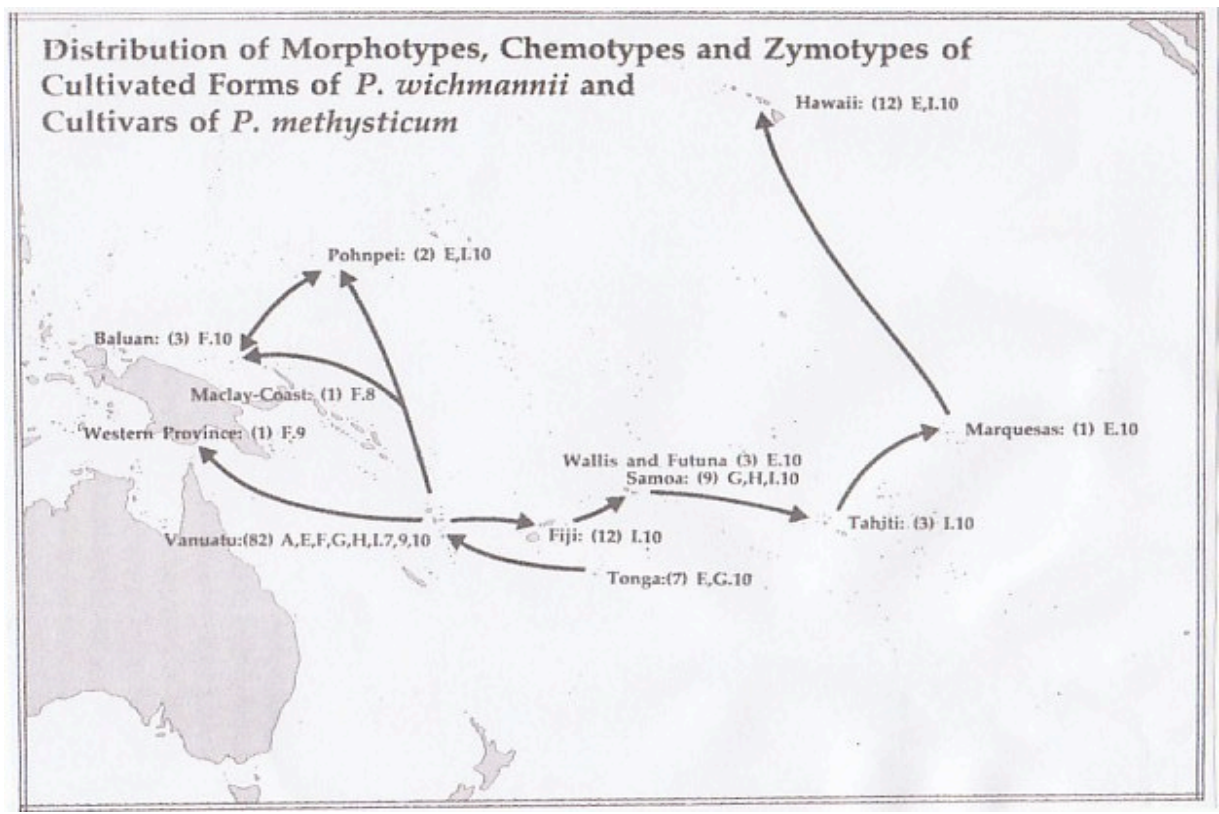

Figure 1- 5. Distribution of Piper methysticum and Piper wichimannii based on morphology, character, chemistry, and zymotypes. Source: Lebot et al. (1997).

\section{1-3-3. Ecology and habitat}

Wati or Kava is a plant which needs hedges for growing. This plant can grow well in the tropics with temperature between $20-35{ }^{\circ} \mathrm{C}$ and a rainfall of more than $2000 \mathrm{~mm} /$ year in a constantly highly humid climate. The soil should contain organic matter with a $\mathrm{pH}$ of $5.5-6.5$. For planting Wati or Kava a good 
drainaged soil is required. This plant is resistant to fast blowing wind (Onwueme, 2000).

\section{1-3-4. Reproduction}

The propagation of Wati is effected by cutting stems (Lebot et al. (1997), Hidayati and Fauzia (2002), Kameubun (2003). However, Piper methysticum has flowers and cannot reproduce itself alone because it is dioecious (Lebot et al. (1997) and sterile (Lebot and Levesque, 1996).

\section{1-3-5. Chemical effect}

It is known that each part (root, stem and leaves) of the Wati plant contains useful chemicals:

Generally, Wati or Kava contains in the root, stem and leaves kavain and dihydrokavain (marindinin) as narcotics, and methysticin and dihydromethysticin as sedatives. The sedative effect caused by dihydromethysticin is slower compared to methysticin but its effect lasts for a longer time. Another compound found in Wati is yangonin (Agusta, et. Al., 1997). The cultivar Alia from Hawaii contains kavalacton from $8.9 \%$ to $20.8 \%$ at the root base. The KL ratio (in $\%$ ethanol extract) totals around 0.55 to $0.80 \%$. The six detected mayor kavalactones are methysticin, dihydromethysticin, kavain, dihydrokavain, demethoxyyangonin and yangonin (Lebot et al., 1999).

According to (Baum et al., 1998), the Kava root extract contains dihydroalphapyrones, D,L-kavain, dihydromethysticin, $\alpha$-yangonin pyrones and desmethoxyyangonin, alkaloids (1-I-methoxynoryangonin, 1-Imethoxymethysticin, tetrahydroyangonin, 5-hydroxy-dihydrokavain). These compunds are deemed to be the active compounds in Kava drinks.

According to Yolmen (1997), the analysis of the cortical stem effected by ethanol and chloroform revealed a content of 1.06\% alcohol. Agusta and Yuliasri (2007) reported the content of a stem extract, and Agusta et al., (1997) of Wati leaves from the village Soa (Marind Land) in the Merauke regency using GCMS 
(gas chromotography mass spectrometry) with the diluents hexane, chloroform and methanol. More details are given in table 1-1 and table 1-2 in appendix 2.

From the root to the stem the kavalacton concentration is decreasing in Wati plant cultivars from Hawaii, PNG, Samoa and Pohnpei. The lowest concentration is found in the leaves (Lebot et al., 1999).

Lectenberg et al. (1999) described the chemical structure of the six major kavalactones in P. methysticum from South Pacific islands: Kavain (K), dihydrokavain (DHK), methysticin (M), dihydromethysticin (DHM), yangonin (Y), demethoxyyangonin (DMY) (Figure 1-6) :

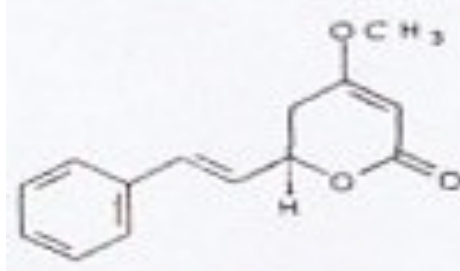

1 (4) -Kavain $(K)$

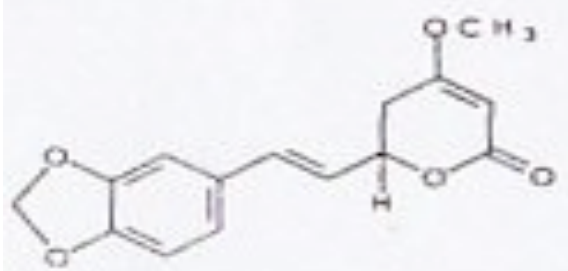

3 (+)-Methysticin (M)

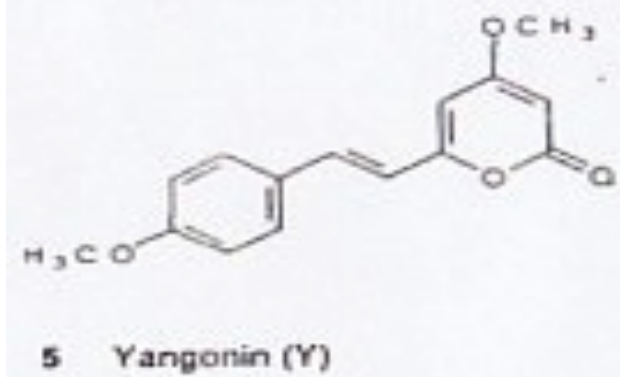

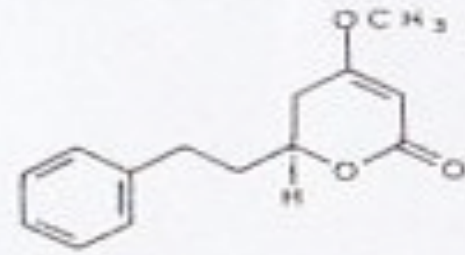

2 (+)-Dihydrokavain (DHK)
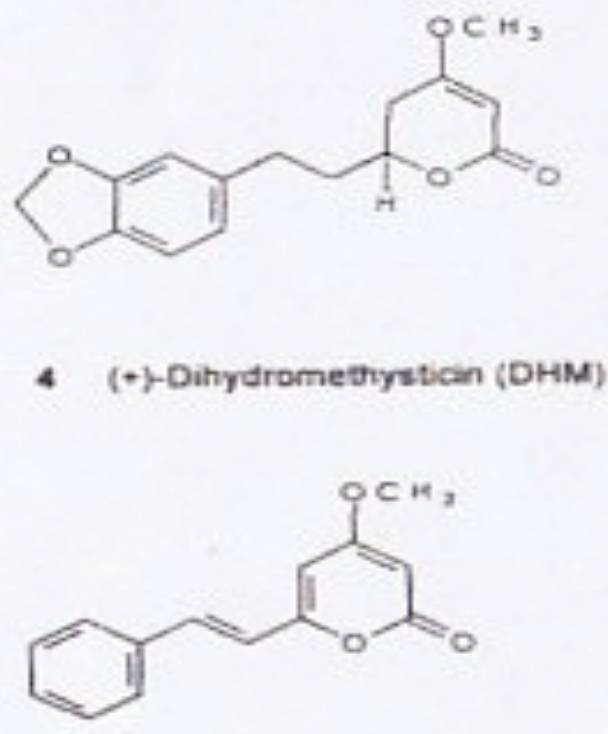

6 Demethoxyrangonin (DMY)

Figure 1-6. The chemical structure of six kavalactones from Piper methysticum 
The pharmacological effect of P. methysticum (as kava-kava or Wati) is similar to diazepam (valium) (Onwueme (2000)). Over-consumption can result in paralysis and skin lesions. According to Baum et al. (1998)), dihydrokavain, kavain and yangonin have no influence on sleep. Kava given at high doses causes relaxation, improves social interaction and activity, resulting eventually in a feeling of sleepiness (Baum et al., (1998)).

The feeling of sleepiness dominates after digestion. There is a local anaesthetic effect on the tongue and the musculus risorius. It sis discussed whether this change creates a lack of appetite and in the long run a body weight decrease.

Yangonin, methysticin, dihydromethysticin, kavain, dihydrokavain and demethoxyyangonin are regarded as effective to cause drowsiness, as an antibiotic, anaesthetic and muscle relaxant. The compounds kavain and dihydrokavain (marindinin) act as a narcotic, methysticin and dihydromethysticin as a sedative. Dihydrokavain, dihydromethysticin and kavain have a sedative and a muscle relaxant effect (Onwueme, 2000).

Alcaloids contained therein can be used for mitigating pain, reducing body temperature, reducing high blood pressure and fighting tumors, as an antiseptic and a therapy for gonorrhoea (Agusta, 2000). The chemical content of species from the genus Peperomia and Piper is listed in table 1-3:

Table 1-3. Chemical composition of substances per 100 grams ingredients of dry Wati.

\begin{tabular}{|l|l|c|}
\hline No & \multicolumn{1}{|c|}{ nutrient substance } & $\begin{array}{c}\text { amount of substance in units } \\
\text { [gram] }\end{array}$ \\
\hline 1 & Water & 12 \\
\hline 2 & protein & 3.6 \\
\hline 3 & starch & 43 \\
\hline 4 & sugar & 3.2 \\
\hline 5 & fiber & 20 \\
\hline 6 & ash & 3.2 \\
\hline 7 & kavalactone & $3-20$ \\
\hline
\end{tabular}

Source : Onwueme, (2000) 


\subsubsection{Economic Value}

In Fiji, Wati plant or Kava has been used for tea and coffee. The product name is Fiji Yaqona (Kava). The product is processed from roots. It contains a soft powder for preparing tea or coffee. The price per 50 grams was $\$ 2.85$ in 2009 (Figure 1-7).

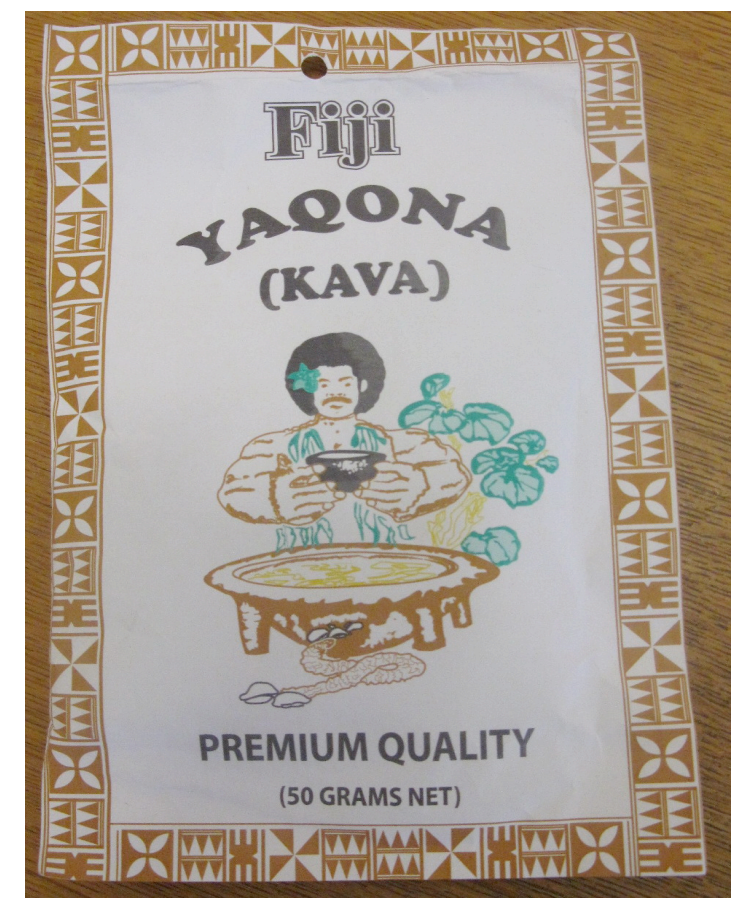

Figure 1-7. Kava product on Fiji islands (Photo by KMB Kameubun).

Besides Yaqona from Fiji, Kava has also been in medical and dietary supplement products. The brand name is "Thompson". It serves for sedation, for decreasing anxiety and for muscle relaxation. The price per bottle was 513.000,00 Indonesian rupiahs in 2011 (ca. 50 Euro, Figure 1-8).

Beside medical purposes, a dietary supplement product is "Kava Root". It can help to reduce nerve tension, stress, anxiety menopause-related disorders, It also supports physical and mental relaxation and is useful in people with sleep disorders (insomnia). The price of the product was $\$ 34.95$ in 2011 (ca $27.70 €$; Figure 1-9). 


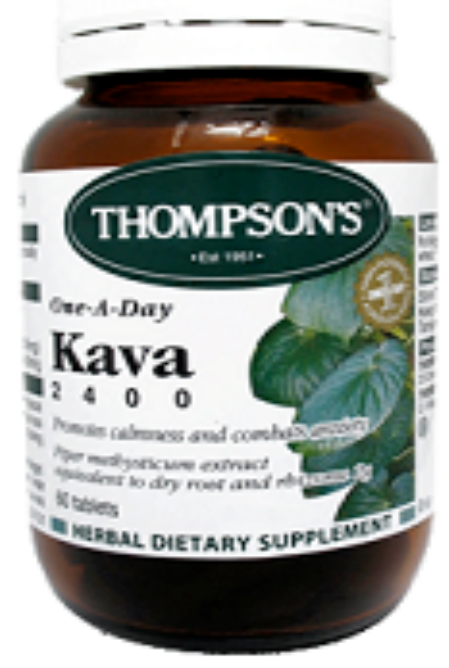

Figure 1-8. The product "Thompson" produced from Kava (Piper methysticum) (Photo from http://www.rumahfarmasi.com/thompsons-thompson-kava-2400mg-tablets-p886.html)

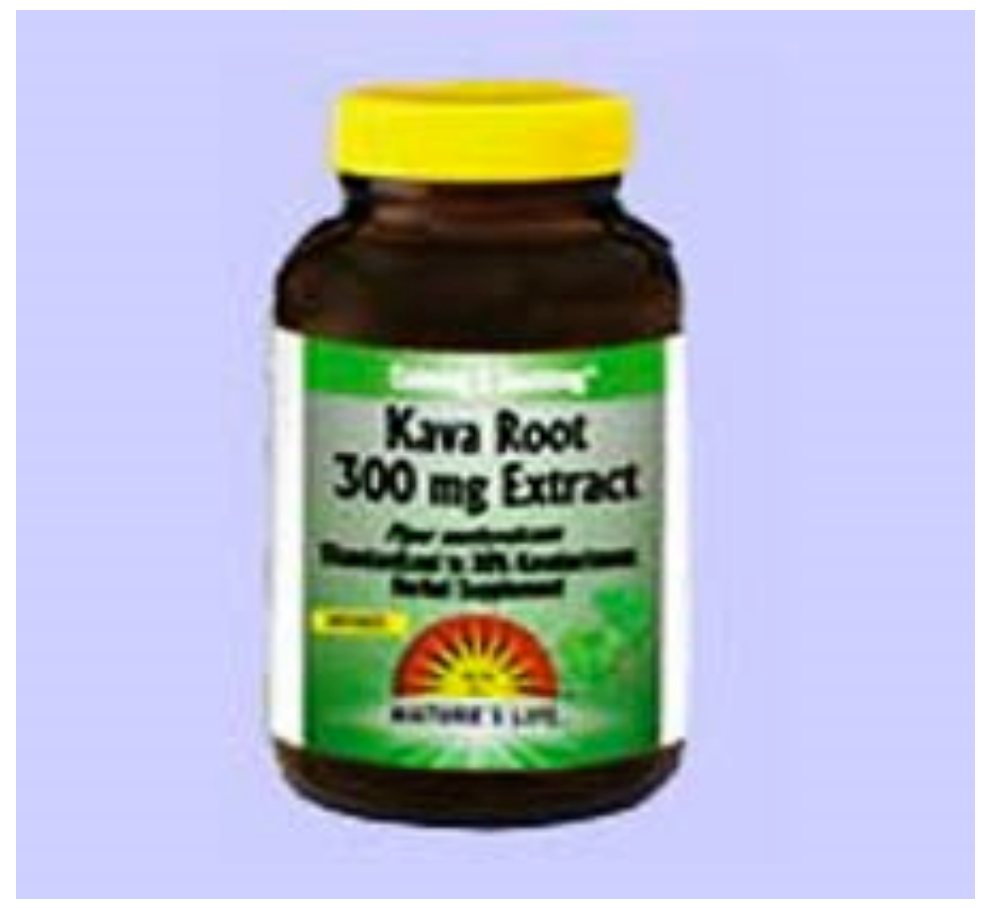

Figure 1-9. The product "Kava Root" (Piper methysticum) (Photo from http://www.global-supplements.com/Kava-kava) 


\section{1-4. Research: Background}

Papua has \pm 250 tribes or ethnic groups. It harbours 246 families, 1.500 genera, and $20.000-25.000$ species of vascular plants. The vascular plants more than half of all species is endemic to Papua (CI, 1999). Muller (2005), in Papua, there are 644 species not found in Australia. There is a high indigenous knowledge of medical plants in Papua.

Wati is used in Marind tribe. Wati plant is used in social interactions between individuals as well as between groups of Marind tribe, but the ethnobotany was not yet comprehensif studied of 3 groups of Marind tribes. Thus that important to do ethnobotany study. Ethnobotany study done to got indegenous knowledge about identification dan classification, utilization, cultivation, and conservation of Wati plant in 3 groups of Marind people.

The morphological description of 4 cultivars of Piper methysticum in Merauke by Kameubun (2003) is not a strong guideline for the taxonomic status. Morphological characters can be influenced by environment. The classification based on morphology is not an ideal result (Rifai 1976). Nevertheless the morphological classification is the fastest way in the analysis of the diversity of plants. The anatomic approach can not give a different character for cultifar level but it can give a different character at the species level. Therefore, to clarify the taxonomic status of the varieties requires other approaches beside morphology and anatomy. In this case, Wati plant needs genetic investigation from all morphology variation of Wati plants.

The geographical distribution of Wati (Piper methysticum) reported by Lebot, et al., (1997) and Kameubun (2003). A monitoring of Kava to be done from year by year, it is necessary to monitor the existence of the species to knowing distribution area from Kava in the world. 


\subsubsection{Research questions}

1. What is the indigenous knowledge of 3 groups of Marind community about classification, utilization and cultivation of Wati plant?

2. Is there a difference of indigenous knowledge between the 3 groups of Marind community?

3. Are there conservation efforts of Wati plant in the 3 groups of Marind?

4. Is there posibility to obtain the number of cultivars of Piper methysticum species (4 cultivars) in Merauke as a report by Kameubun (2003) if research area to be done in 3 groups of Marind tribe?

5. How is the genetic diversity of Wati cultivars in Merauke area?

6. Do Marind populations use different genetic variants of Wati?

7. Which relationships exist between the morphological and genetic variants of Wati?

8. Is the distribution monitoring from 2003 to 2010 of Kava based of the collection of herbarium specimen increased compared to other island or is it the same as in Kameubun (2003)?

\subsubsection{The aim}

The aim of this research is therefore:

1. To know the indigenous knowledge of three groups of Marind tribe about classification, utilization, and cultivation of Wati plant (Piper methysticum Forst.)

2. To review indigenous knowledge three group of Marind tribe did classification, utilization, and cultivation Wati plant (Piper methysticum Forst.) with scientific rule based on taxonomy and moleculer used morphology and genetic approach.

3. To analyze the genetic diversity of cultivars of Piper methysticum using microsatellite marker (SSRs) in order to determine the taxon status of cultivars of Piper methysticum .

4. To inventory and monitor the distribution of Wati plant in Marind tribe area and in the world based on herbarium specimens. 


\subsubsection{Benefit of the research}

By applying a molecular approach in this research comprehensive data about the taxonomic status was obtained. This research became the basis for the ensuing research about the utilization of the respective chemical compunds. The results may be useful for medical application and dietary supplement studies of the Wati plant.

Through the understanding of the biogeographic distribution of Piper methysticum the original habitat can be identified and the migration (respectively the transport for trade) of Wati can be estimated.

\subsection{Study sites}

\subsubsection{Location}

The regency of Merauke changes administratively from year to year. In 2002 before divided of the regency the area of Merauke spread $137^{\circ}$ to $141^{\circ}$ Eastern longitude and $5^{\circ}$ to $9^{\circ}$ Southern latitude covering an area of $119.749 \mathrm{~km} 2$ or 28.87 $\%$ of the Papua province $\left(416.000 \mathrm{~km}^{2}\right)$. The regency of Merauke is bordered by the regencies of Jayawijaya in the North, Timika in the West and shares a sea border with Arafura in the South (BPS, 1997; 1999, CI, 1999 in Kameubun, 2003) (Figure 1-10). In 2004 the regency of Merauke was split into four regencies: Mapi, Boven Digul, Asmat, and Merauke.

Merauke regency up to now (2013) borders in the East with Papua New Guinea (PNG), in the South and the West it borders with the Arafura Sea (Figure 1-10). Now the regency of Merauke covers $45.071 \mathrm{~km}^{2}$. It is located between $130^{\circ}$ and $141^{\circ}$ Eastern longitude as well as $5^{\circ}$ to $9^{\circ}$ Southern latitude (BPS, 2007).

Before the splitting of the Merauke regency the Marind community was spread over five out of 23 districts of Merauke. The five districts were Kimaam, Okaba, Kurik, Merauke and Muting (Kameubun, 2003). After the splitting the regency of Merauke regency is subdivided into 20 districts. People of the Marind tribe are spread over these 20 districts. The Marind Beach (Marind Pantai / Marind dufh) community lives in six districts (Tubang, Okaba, Malind, 
Semangga, Merauke, Naukenjerai district), the Marind Land (Marind Darat / Marind degh) in 13 districts (Iwayab, Tubang, Ngguti, Kaptel, Kurik, Tanah Miring, Merauke, Sota, Jagebob, Animha, Muting, Elikobel, Ulilin) and the Marind Swamp (Marind Rawa / Marind bob) in four districts (Waan, Tabonji, Kimaam and some areas of Iwayab) (Figure 1-10).

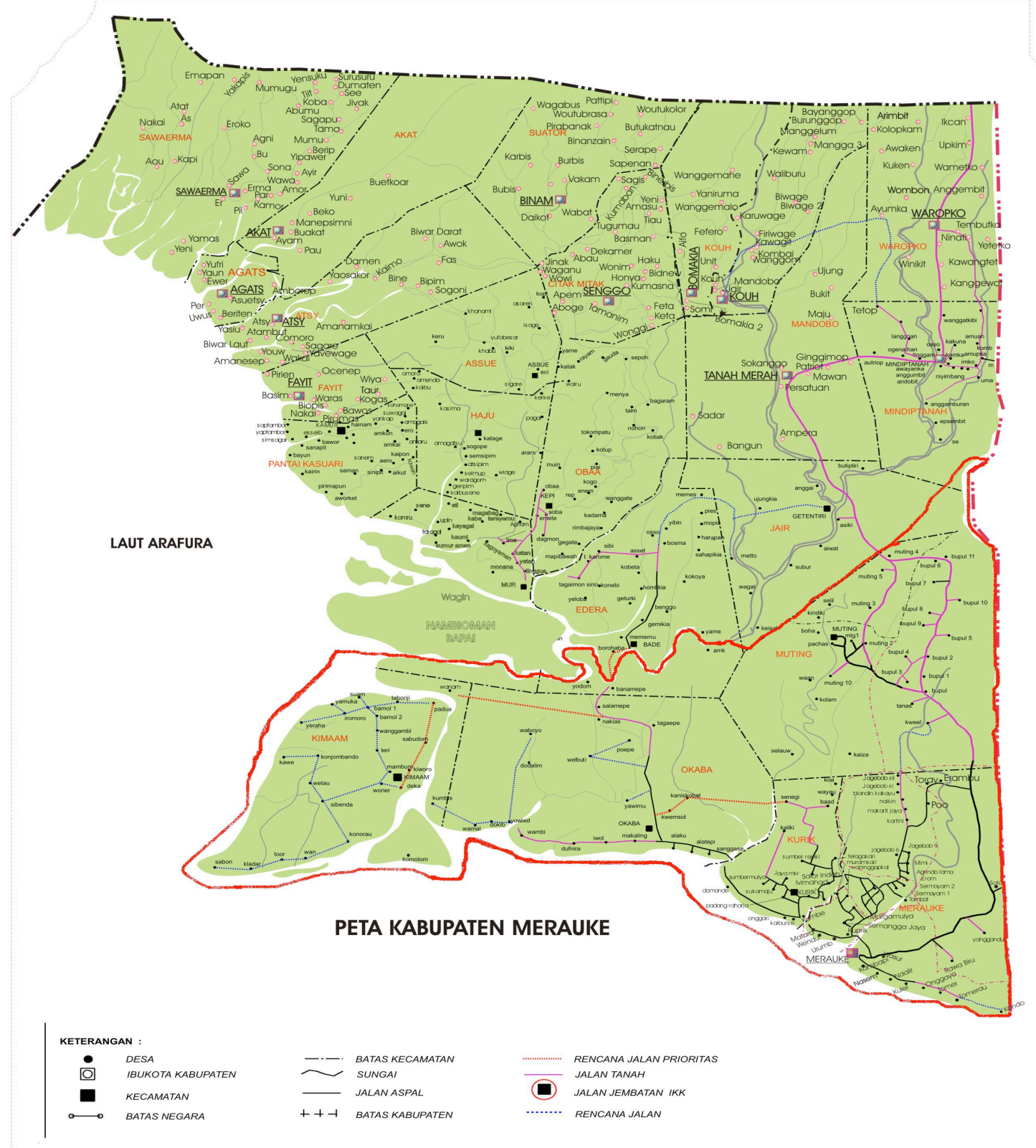

Figure 1-10. Map of the regency of Merauke before and after the splitting into four regencies. Source : BAPEDA regency of Merauke, 2009. Note: The red line delimits the regency of Merauke regency after the splitting. 


\section{1-5-2. Climate}

The average air temperature in 2007 to 2009 was around $27.1^{\circ} \mathrm{C}$. The maximum air temperature was $33.8^{\circ} \mathrm{C}$ and the minimum $19.6^{\circ} \mathrm{C}$ (Figure $1-11$ ). The rainfall statistics for every month (years 2007 to 2009) from Merauke station show that the highest rainfalls were from January to April and the lowest rainfalls from May to December (Figure 1-12).

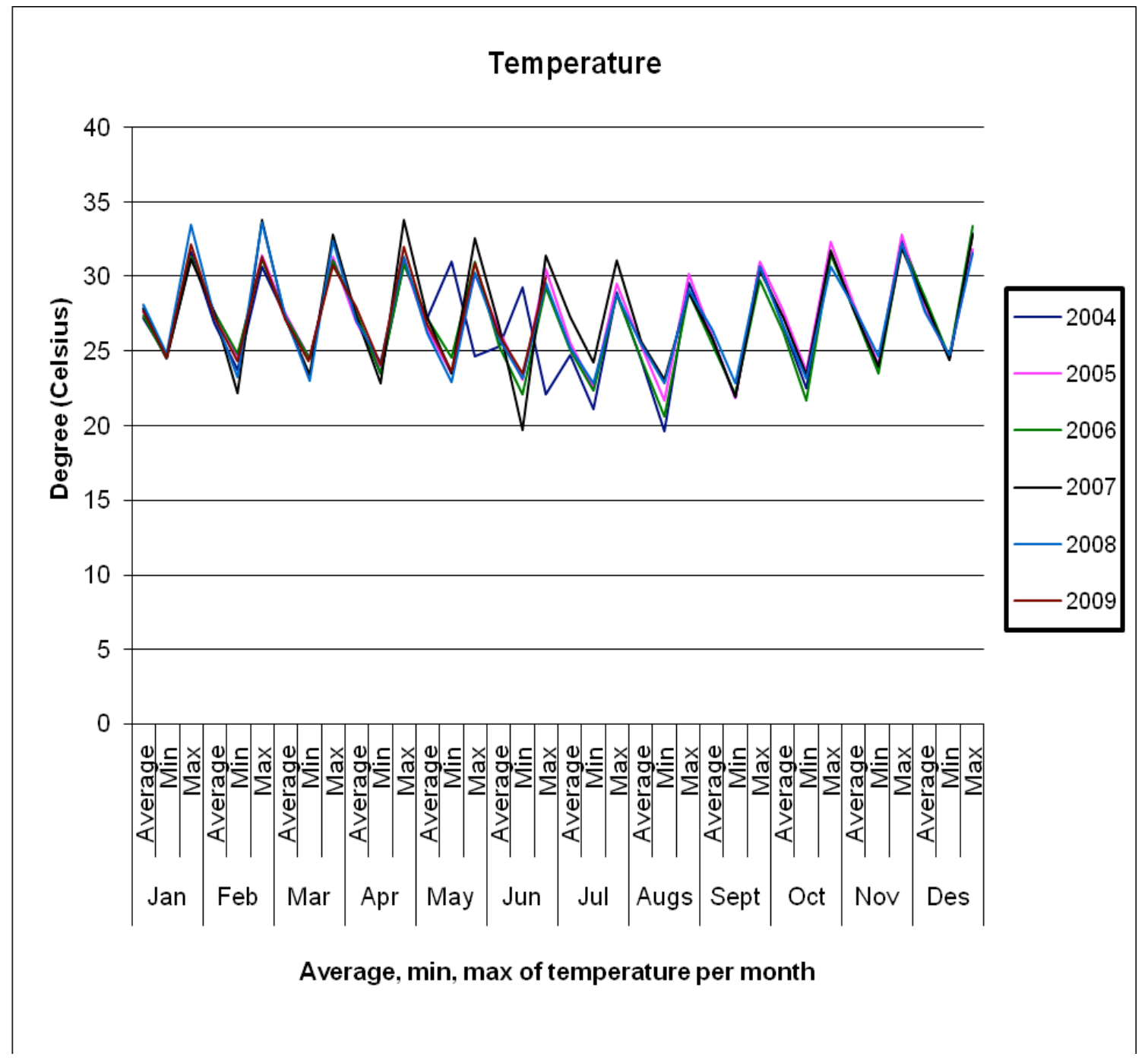

Figure 1-11. The average, minimum and maximum air temperature 2007 to 2009 in the regency of Merauke. Source: Government Division of Meteorology and Geophysics Merauke regency. 


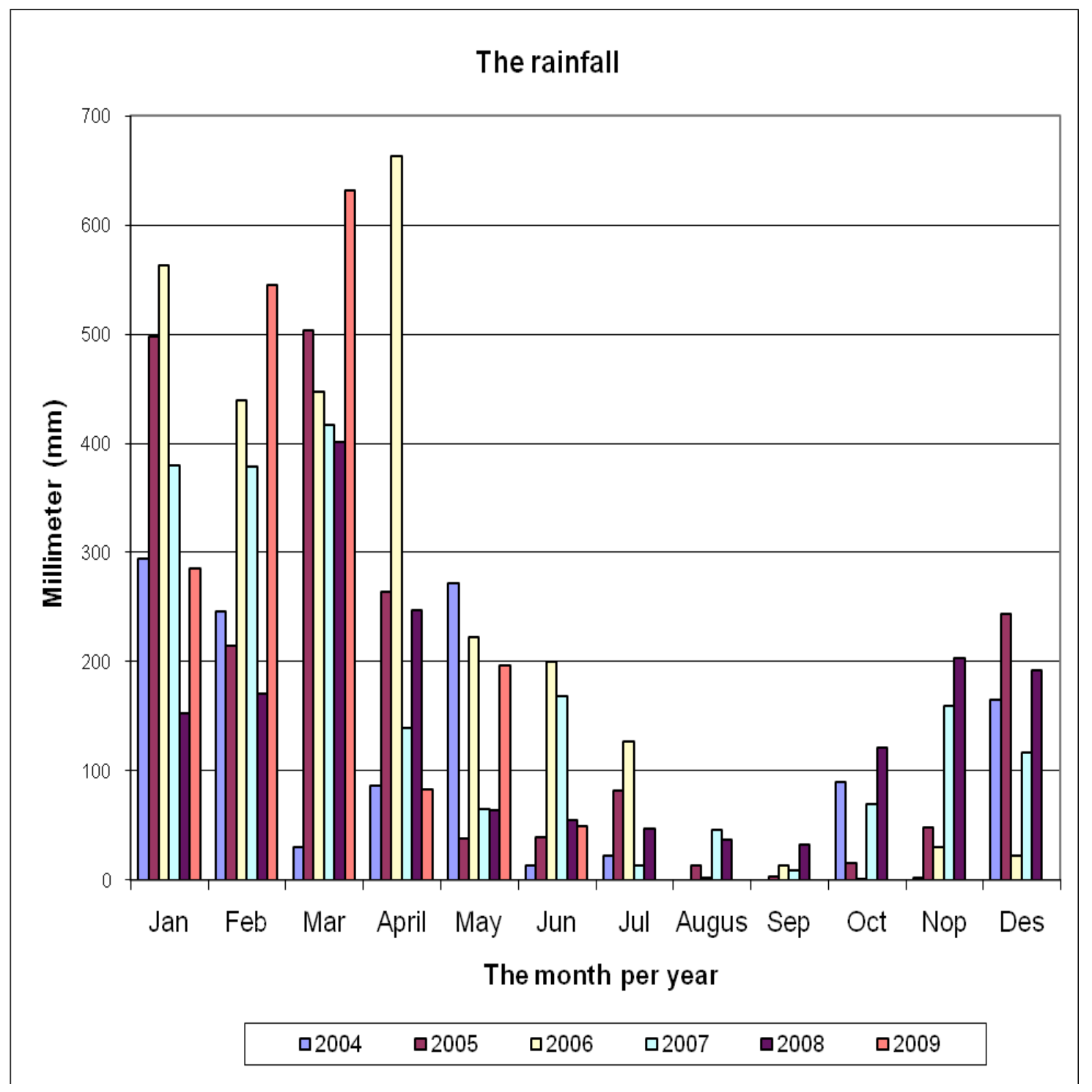

Figure 1-12. Rainfall 2007 to 2009 in the regency of Merauke. Source: Government Division of Meteorology and Geophysics Merauke regency.

\section{1-5-3. Vegetation}

The Merauke area has a high diversity of lowland habitats, such as Melaleuca and Eucalyptus forests, savannah, swampy areas, mangrove forests, lowland forests and a wide tidal area (Petocz, 1987). There is one national park in the regency of Merauke, the Wasur National Park. About $70 \%$ of its area is savannah, the rest are swampy forests, beach forests, bamboo forests, and there is a wide area of Sago swampy forests. Plant species dominating in the swampy 
forests of the Wasur National Park are Avicennia sp. (in Bahasa Indonesia: apiapi), Bruguiera sp. (in Bahasa Indonesia: tancang), Terminalia sp. (in Bahasa Indonesia: ketapang), and Melaleuca sp. (in Bahasa Indonesia: kayu putih) (Dephut, 2010).

\section{1-5-4. Altitude}

The regency of Merauke is situated between 0 and 60 meters a.s.1. (table 14 in appendix 3 ).

\section{1-5-5. Demography}

The total population of Merauke regency was 194.862 in 2009. There are no reliable data available about the Marind tribe. However, all people from Papuan tribes accounted to 74.137 and the non-natives to 120.725 people (table 15 in appendix 3).

\subsubsection{Livelihood}

The main livelihood of the Marind people depends on the natural resources of the respective environment. Furthermore, there is a strong influence of the climatic conditions. During the the rainy season swamps, rivers and Sagu gardens, are flooded. Therefore the daily activities of the rural society are mostly limited to their village and their life centers on saving food. In the dry season they would collect natural resources, for example fish, snails, shrimps, crabs, and the hunt of mammals (Dinas Sosial, 1972).

According to Overweel (1990), different environment cause differences in the livelihood. In the beach area the variety of food sources is higher than in the land area (Marind Land/ Marind Darat). In the beach area there is more fresh water and sea water fish available. Coconut palms grow there and yield a lot of fruits. In the land area there are many fresh water fish and forest animals to be 
hunted, such as deer, cassowary, kangoroo and Pig. In the Marind Swamp (Marind Rawa / Marind bob) area there is abundant fresh water fish and animals such as deer, kangaroo and boar are hunted, like in the land area (Marind Land).

A large portion of the Marind Land area is used for settlements for the people from the transmigration programme. Transmigration carries along the acculturation to food with introduced plants, from rice (Oryza sativa) to sago (Metroxylon sagu). As animals they keep cows, deer (Cervus timorensis), kangaroos (Thylogale brunii) and pigs (Sus vittatus) which build the main protein source (Kameubun, 2003). This custom can now also be found in communities of Marind Beach (Marind Pantai / Marind dufh) people. Recently, they started growing rice in paddies close to where they live. The harvested rice is consumed in particular by local children or teenagers who tend to prefer rice everyday over sago which is the traditional primary staple of the Marind tribe. 


\section{Chapter 2. MATERIALS AND METHODS}

\section{2-1. Research location}

The field research was done in 32 villages from three groups of Marind tribes (Figure $2-1$ ):

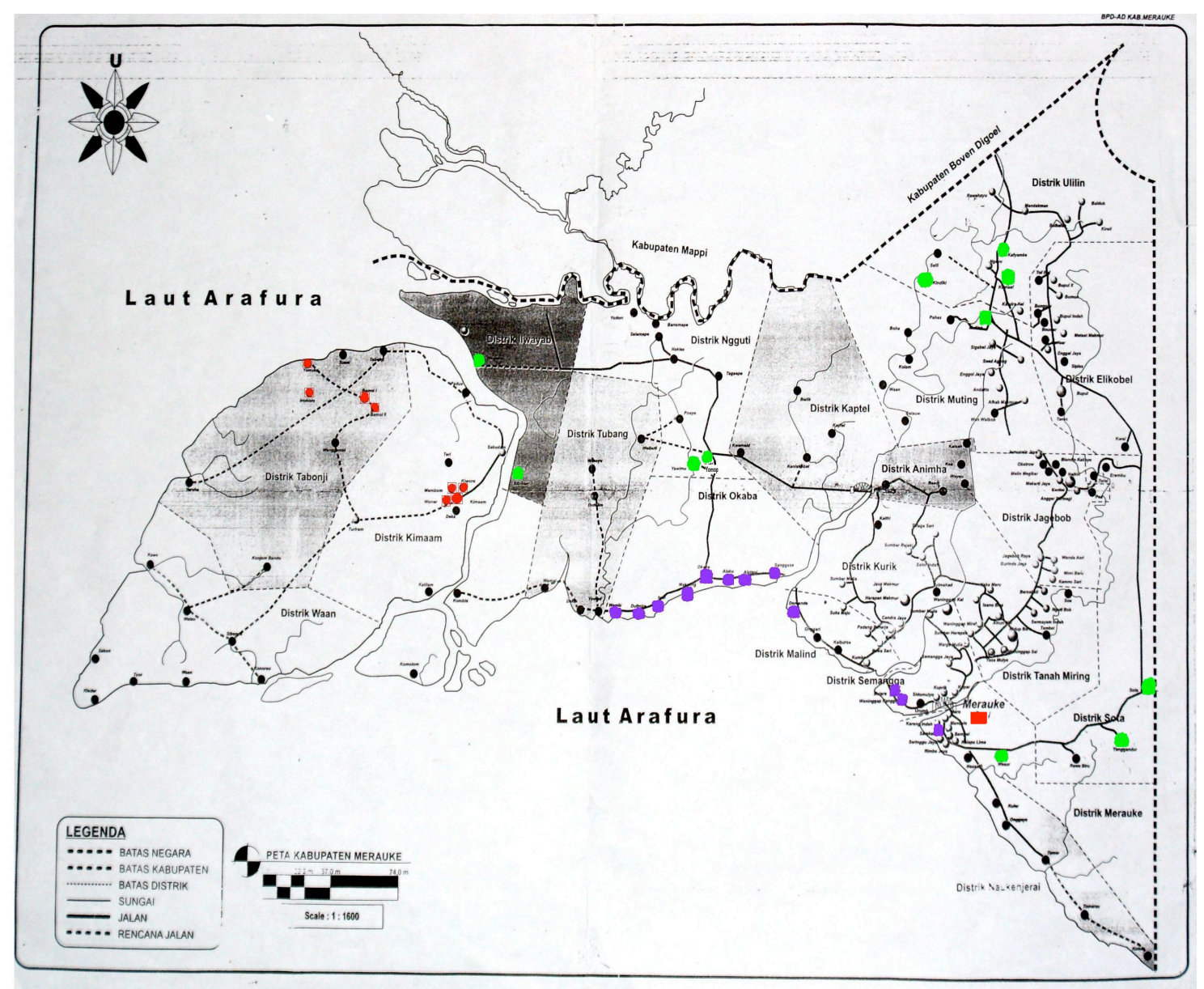

Figure 2-1. The map: Merauke regency after it has spreaded to 4 regencies. Source: BAPEDA Merauke regency, 2009.

Explanation of merauke: $\square$ Merauke city, Capital of Merauke Regency

$O$ : Villages in Marind Swamp (Marind Rawa / Marind bob) area.

$\mathrm{O}$ : Villages in Marind Beach (Marind Pantai / Marind dufh) area.

: Villages in Marind Land (Marind Darat / Marind degh) area.

----- = boundary of Merauke regency area 
Village names based on every group of Marind tribes are:

a). Marind Swamp (Marind Rawa / Marind bob) villages are Bamol 1, Bamol 2, Iromoro, Yamuka, Kimaam, Woner, Mambum (8 villages).

b). Marind Land (Marind Darat / Marind degh) villages are wogikel/ Wanam, Bibikem, Yawimu, Yomop, Wasur, Yanggandur, Sota, Muting, Kumaaf, Kafgamke, Kindiki (11 villages).

c). Marind Beach (Marind Pantai / Marind dufh) villages are Wambi, Dufmira, Iwol, Makaling Okaba, Alaku, Alatep, Sanggase, Domande, Wendu, Bahor, Urumb, Buti (13 villages)

\section{2-2. General Methods}

This research used 2 primary approaches: the emic and the ethic approach (Walujo, 1998: Walujo, 2004). Data collected included the primary and secondary data. The primary data were collected by interviews. The secondary data were obtained through literature studies from reports, notes such as map, demography data, geomorphology, climatology data from BAPEDA (Government Division of Regional Secretary departement), BPS (Government Division of Statistical Centre), National land board department and BMG (Government Division of Meteorology and Geophysics), of Merauke, Papua province.

\section{2-2-1. Method in ethnobotany study}

To collect data in the field, survey method and participative observation were used to get qualitative data (Cotton, 1996). Survey method was used to unravel the knowledge of society about Wati (Piper methysticum Forst) and the participative observation method was to involve society as guides and informant.

To describe the certain social indication, purposive sampling was used (Walujo, 2004). The interview was done with the society of the three Marind tribes that stay in villages where Wati plants were found.Semi-structured interviews were done with more than 100 people consisted of the pillars of the 
community such as head of districts, head of villages, and head of custom, and people who have knowledge about culture of the Wati plant. The question list (Simple Question) can be found in appendix 4.

\section{Analysis of ethnobotany data}

Ethnobotany data was described based on a circuit of cause and effect to find a learning from indigenous knowledge.

Frequency distribution was used to compare answers within each ethnic group. The fidelity level (FL) (Ekue, 2009) was calculated using the following formula: $\mathrm{FL}=\mathrm{Ip} / \mathrm{Iu} \times 100 \%$, where Ip is the number of informants answering positively on each question. Iu is the total number of positive answers for each category of the questionnaire. The index of FL was used to measure the consensus degree between informants and the relative importance of each category of knowledge within each ethnic group.

\section{2-2-2. Method in botany study / Taxonomy}

The survey and observation methods were used to collect data in the field. Those methods were used to inventory the gardens and the variety of Wati plant per village. The observation method was used to see the morphological identity of Wati plant in the gardens in each village.

The stems, leaves and flower of Wati plant were taken for making dry herbarium specimens for further identification in Bogoriense Herbarium, Bogor Indonesia and for the identification using literatures, such as: Kava the Pacific elixir (Lebot, Mark Merlin, dan Lamont Lindstrom).

The variables of morphological observation on Wati plant population in the three groups of Marind tribes are including habitus, stem colour, lenght of internode stem, leaf and flower. Plant anatomy data (Kameubun, 2003) was used for the comparison with morphological data of the variation of Wati plant. 
Supplementary data in the field referred to identification and ecological aspects comprise of altitude above sea level, habitus, environmental temperatures, distance between the gardens and the house, and distance between the gardens and the villages.

Data on distribution of Piper methysticum plant in the world was done based on the data of herbarium specimen collection in some herbariums. The data were gathered from Herbarium National Leiden in Netherland, Herbarium National Australia Canbera (CANB) in Australia, Herbarium Kew in England via email. The data from Herbarium Bogoriense were gathered directly by the researcher. Herbarium Manokwari-Papua did not have specimen collection of Wati plant. Herbarium Fiji could not give their data of herbarium collection.

\section{Analysis of taxonomy and distribution data}

Morphological data was made in such a matrix form. The matrix data was processed using software program, statistical version 8.0, and NTSYSpc program version 2.021 to analyze the similarity.

Similarity analysis uses Nei and Li methods to classify the variable homogeny group. Similarity matrix was analyzed by using SIMQUAL technique (Similarity for Qualitative data). Coefficient of similarity was obtained using especially Dice method including SAHN clustering by UPGMA (Unweighted Pair Group Method with Arithmatic) for presenting a dendogram.

Similarity analysis processes consist of: (1) morphological datum matrix by using scoring way of every identity with $0,1,2$. (2) Standardization of data (3) Matrix input data (4) similarity dendrogram.

\section{2-2-3. Method in genetic studies}

For the analysis of the genetic diversity of the Wati plant, nuclear microsatelite markers (nSSRs) and cloroplast microsatelite markers (cpSSRs) were used. 


\section{Plant material}

Plant material was collected from three different populations of Wati plants in the garden of Marind tribe, in Merauke, situated in the similar climatic condition (homogen climate). The population samples were denoted according to their geographical location (Fig.1-11) as: Marind Land (Marind Darat/Marind degh), Marind Beach (Marind Pantai/Marind dufh) and Marind Swamp (Marind Rawa/Marind bob). Within each location, adult plants were randomly sampled. In total, leaves were collected from 172 individuals and dried in the field using silica gel. Each population was represented by 30 individual plants per cultivar and sample were collected for those plants. Table 2-1 describes the geographic location and the sample size of each population .

Table 2-1. The total number of Piper sample in 3 populations Marind tribes in Merauke.

\begin{tabular}{llcc}
\hline Population & Species & $\begin{array}{c}\text { Missing data** } \\
\text { from 172 sample }\end{array}$ & $\begin{array}{c}\text { Number of sample } \\
\text { analysis to clone }\end{array}$ \\
\hline Marind Beach & Piper methysticum & 5 & 35 \\
Marind Beach & Piper wichimannii * & 0 & 0 \\
Marind Beach & Piper betle & 1 & 9 \\
Marind Swamp & Piper methysticum & 7 & 33 \\
Marind Swamp & Piper wichimannii * & 0 & 0 \\
Marind Swamp & Piper betle & 1 & 9 \\
Marind Land & Piper methysticum & 4 & 29 \\
Marind Land & Piper wichimannii * & 4 & 26 \\
Marind Land & Piper betle & 1 & 9 \\
\hline \multicolumn{2}{c}{ Total of sample } & 23 & 150 \\
\hline \multicolumn{2}{c}{ * cultivar Marub (Kameubun, 2003), ** unidentified haplo- and phenotypes }
\end{tabular}

\section{DNA isolation}

Total DNA was extracted from a small slice (approximately $1 \mathrm{~cm}^{2}$ ) of dried leaf tissue following the Dneasy ${ }^{\mathrm{TM}}$ Plant Kit protocol of the manufacturer (Qiagen, Hilden, Germany). The quality and quantity of the DNA was analyzed 
by $1.5 \%$ agarose gel electrophoresis with $1 \mathrm{x}$ Tris-acetate (TAE) as running buffer. DNA was stained with ethidium bromide and visualized by UV illumination.

\section{PCR amplification}

For the analysis of nuclear DNA nine microsatellite- (or SSR- simple sequence repeat) markers originally developed for Piper nigrum (Menezes et al., 2009) were used and for the analysis of the cp (chloroplast) DNA ten universal microsatellite-markers (ccmp1 to ccmp10) described by Weising and Gardner (1999) were investigated. PCR amplification was performed in a $14 \mu$ l volume containing of $2 \mu \mathrm{l}$ DNA, and $12 \mu \mathrm{l}$ of HotStar Tag Master Mix PCR (1.5 $\mu 1$, PCR concentration buffer, $1 \mu \mathrm{MgC} 12,1 \mu \mathrm{dNTP}, 1 \mu \mathrm{l}$ primer forward, $1 \mu \mathrm{l}$ primer reserve, $6.8 \mu \mathrm{l}$ RNAse free water, $0.2 \mu \mathrm{l}$ Tag polymerase). All amplifications were performed in a Peltier Thermal Cycler (PTC-0200 version 4.0, MJ Research). The PCR protocol consisted of an initial denaturation step of $95^{\circ} \mathrm{C}$ for $15 \mathrm{~min}$, followed by 34 cycles of $1 \mathrm{~min}$ at $94^{\circ} \mathrm{C}$, a $1 \mathrm{~min}$ annealing step at $53^{\circ} \mathrm{C}$ (primer pairs $\mathrm{PN} \mathrm{B} 5, \mathrm{PN} \mathrm{D} 10$, and $\mathrm{PN} \mathrm{G11)}$, at $50^{\circ} \mathrm{C}$ (primer pair ccmp2), $72^{\circ} \mathrm{C}$ for $1 \mathrm{~min}$ (extension), and a final extension step of $72^{\circ} \mathrm{C}$ for $20 \mathrm{~min}$. Primer pairs were preliminarily tested by running PCR products on $1.5 \%$ agarose gels in $1 \mathrm{x}$ TAE buffer at 94 volt for $30 \mathrm{~min}$. Microsatellite alleles were analyzed on an automatic sequencer ABI Genetic Analyzer 3100. The PCR reactions were carried out with one primer (the forward primer) labeled with fluorescent dyes (Metabion) green for PN B5 and PN D10, and blue for P G11 and ccmp2. Fragments were separated on the ABI Genetic Analyser in a multiplex analysis. GeneScan 500 ROX (fluorescent dye ROX) was used as internal standart (Applied Biosystems). The fragment size of the microsatellite alleles were analysed by using the software packages GeneScan version 3.7 and Genotyper version 3.7 from Applied Biosystems. 
Table 2-2. The list of SSR primer used in the research

\begin{tabular}{|c|c|c|c|c|c|}
\hline Primers & $\begin{array}{l}\text { Gen Bank accession } \\
\text { number }\end{array}$ & Primers sequences $\left(5^{\prime}-3^{\prime}\right)$ & Motive & $\begin{array}{l}\text { Range size of length } \\
\text { fragment (bp) }\end{array}$ & Amplification \\
\hline \multirow[t]{2}{*}{ PN D10 } & FJ 374758 & F 5' GTGTTACCTTTGGGGCATTCA 3' & (GT)13 & $216-296$ & + \\
\hline & & R 5' TGTGTCAGGGCATCAAACC 3' & & & \\
\hline \multirow[t]{2}{*}{ PN G11 } & FJ 172210 & F 5' TTACTAGTGTCCACCCCCACT 3' & $(\mathrm{AC}) 5$ & $210-238$ & + \\
\hline & & R 5' TCGATGGAAAGTCACCCTCT 3' & & & \\
\hline \multirow[t]{2}{*}{ PN H4 } & FJ 172211 & F 5' CTTTTCCCACAATTCAGTCTCG 3' & $(\mathrm{AC}) 9$ & $258-264$ & - \\
\hline & & R 5' ACCCATGCGTGTATCTTCTCAG 3' & & & \\
\hline \multirow[t]{2}{*}{ PN E3 } & FJ 172208 & F 5' TTTGTGTCстCтссСтCTCC 3' & $(\mathrm{CA}) 13$ & $260-298$ & - \\
\hline & & R 5' AAGACTAAATAGGCAAGGCAAA 3' & & & \\
\hline \multirow[t]{2}{*}{ PN B5 } & FJ 172206 & F 5' GTTTTGAATGGGTCGGTGAT 3' & (TG)14 & $258-268$ & + \\
\hline & & R 5' ATTGTTCTGATTTCTTCGTTATTG 3' & & & \\
\hline \multirow[t]{2}{*}{ PN F1 } & FJ 172209 & F 5' ACTTCAGTGCTATTTTTATCTTCC 3' & (TG)11 & $110-152$ & - \\
\hline & & R 5' CCAACGCCСАСТCTCAT 3' & & & \\
\hline \multirow[t]{2}{*}{ PN A5 } & FJ 172205 & F 5' CTTCCAGACCAATAATCAACTT 3' & $(\mathrm{AC}) 19$ & 164-194 & - \\
\hline & & R 5' ATCCCAAAATACACAACAATTC 3' & & & \\
\hline \multirow[t]{2}{*}{ PN H8a } & FJ 172212 & F 5' TGTGTCTTTTATATTTTTGATG 3' & (TG)16 & $266-288$ & - \\
\hline & & R 5' TATTAGTAGTTCTCCCTTTTGA 3' & & & \\
\hline \multirow[t]{2}{*}{ PN B9 } & FJ 172207 & F 5' AGTATTGGTTGTTTCTCTC 3' & (AT)6(AC)9GC(AC)11 & 258-304 & - \\
\hline & & R 5' ATGTAAAATCGATAGTCCTCA 3' & & & \\
\hline \multirow[t]{2}{*}{ ccmp2 } & & 'F5' GAT CCC GGA CGT AAT CCT G 3' & (A)11 & 8609 & + \\
\hline & & R5' ATC GTA CCG AGG GTT CGA AT 3' & & & \\
\hline \multirow[t]{2}{*}{ ccmp3 } & & F5' CAG ACC AAA AGC TGA CAT AG 3' & (T)11 & 10075 & - \\
\hline & & R5' GTT TCA TTC GGC TCC TTT AT 3' & & & \\
\hline \multirow[t]{2}{*}{ ccmp5 } & & F5' TGT TCC AAT ATC TTC TTG TCA TTT 3' & $(\mathrm{C}) 7(\mathrm{~T}) 10$ & 16950 & - \\
\hline & & R5' AGG TTC CAT CGG AAC AAT TAT 3' & $(\mathrm{T}) 5 \mathrm{C}(\mathrm{A}) 11$ & 16977 & \\
\hline \multirow[t]{2}{*}{ ccmp9 } & & F5' GGATTTGTACATATAGGACA 3' & $(\mathrm{T}) 11$ & 74060 & - \\
\hline & & R5' CTCAACTCTAAGAAATACTTG 3' & & & \\
\hline
\end{tabular}

Note: + : amplification product, - : no amplification product.

\section{Analysis of the genetic data}

\section{Transferability of nuclear and chloroplast microsatellites}

In order to find nuclear microsatellite markers which could amplify the DNA of the three species, Piper methysticum, P. wichimannii and $P$. betle nine primer pairs originally developed for Piper nigrum (Menezes et al. 2009) were used and listed in Table 2-2 (see above). In the case of the chloroplast microsatellite markers four (ccmp 2, ccmp 3, ccmp 5 and ccmp 9, also listed in Table 2-2) of ten universal microsatellite primer pairs described by Weising and Gardner (1999) were tested. Out of the tested primer pairs three nuclear microsatellites (PN B5, PN D10 and PN G10) and one chloroplast microsatellite (ccmp 2) were successfully transfered to Piper methysticum, P. wichimannii and P. betle (Table 2-3). The size of the putative alleles (in basepairs, bp) was determined with the software packages GeneScan 3.7 and Genotyper 3.7 (Applied Biosystems Inc.). 
Since all three analysed Piper species are decaploid (Lebot and Levesque, 1996) a complex pattern of fragments were produced by nuclear microsatellites. For all analysed loci all doubtlessly identified fragments were scored and their allele sizes (in $\mathrm{bp}$ ) are listed in Table 2-4. In contrast to the nuclear microsatellites the uniparental inherited chloroplast DNA showed a simple pattern of one band (haplotype) of the amplified microsatellite marker.

Table 2-3. Transferabilty of SSR primer to Piper methysticum, P. wichimannii, and P. betle.

\begin{tabular}{cllc}
\hline No & \multicolumn{1}{c}{ Primers } & $\begin{array}{r}\text { Gen Bank Accession } \\
\text { number }\end{array}$ & $\begin{array}{c}\text { Amplification } \\
\text { ability }\end{array}$ \\
\hline 1 & PN D10 & FJ 374758 & + \\
2 & PN G11 & FJ 172210 & + \\
3 & PN H4 & FJ 172211 & - \\
4 & PN E3 & FJ 172208 & - \\
5 & PN B5 & FJ 172206 & + \\
6 & PN F1 & FJ 172209 & - \\
7 & PN A5 & FJ 172205 & - \\
8 & PN H8a & FJ 172212 & - \\
9 & PN B9 & FJ 172207 & - \\
10 & ccmp2 & & - \\
11 & ccmp3 & & - \\
12 & ccmp5 & & - \\
13 & ccmp9 & &
\end{tabular}

Note: + : amplification product, - : no amplification product.

Table 2-4. Allele sizes of nuclear and chloroplast microsatellite markers

Alleles of all analysed loci $(k)$

Individu:
ccmp2 B5
D10
G11
clone

\begin{tabular}{rlllll} 
Individu: & 240 & 257 & $207,208,210$ & 203,204 & 1 \\
1 & 240 & 257 & $203,204,207,208$ & 203,204 & 2 \\
3 & 240 & 257 & $203,204,207,208$ & 203,204 & 2 \\
$n$ & & & & & \\
\cline { 1 - 3 } & & & &
\end{tabular}




\section{Chapter 3. RESULTS}

\section{3-1. INDIGENOUS KNOWLEDGE OF THREE GROUPS OF MARIND TRIBE FROM MERAUKE ON THE CLASSIFICATION OF THE WATI PLANT (Piper methysticum Forst.) AND THEIR UTILIZATION}

Traditional knowledge of varieties of Piper methysticum Forst. by the Marind tribe could not be assigned individually. It should be referred to the overall group of the Marind tribe, as it is related to the custum for providing information. In general, there is a different motivation for utilization, identification and classification, cultivation and handling practice of the Wati plant among three groups of the Marind tribe (table 3-1). The intention to sell the Wati plant, to use it for ritual ceremonies, to prepare it for the paying of a dowry is reflected in each of the 3 groups of the Marind tribe in the percentage of their land used for their cultivation (Marind Land 87.51\%, Fillial Level $(\mathrm{FL})=31.8$, Marind Beach 76.92\%, FL = 33.33, Marind Swamp 100\%, FL = 24). Casual plantations of the Wati plant were found only at Marind Land $12.5 \%, \mathrm{FL}=4.54$. The casual cultivation of Wati plant in Marind Land was due to people from other ethnic groups but living in the village of Marind Land tribe. The knowledge how to use the Wati plant for a beverage is somewhat high (100\%) in 3 groups of the Marind tribe than using it as a medicine (Marind Land 87.5\%, Marind Beach and Marind Swamp 100\%). People from all groups of the Marind tribe said that the forest is the most fertile place to cultivate the Wati plant $(100 \%$ and $\mathrm{FL}=100)$. The number of varieties (cultivars) of the Wati plant planted in the Marind tribe area in Marind Land are 5 cultivars of Piper methysticum and Piper wichimannii. This is more than in Marind Beach and Marind Swamp (5 cultivars of Piper methysticum). 
Table 3-1. Traditional knowledge of 3 groups of the Marind tribe in Merauke, Papua

\begin{tabular}{|c|c|c|c|c|c|c|c|c|c|c|c|c|c|}
\hline \multirow{2}{*}{\multicolumn{2}{|c|}{ Category/Criteria }} & \multirow{2}{*}{ Variation } & \multicolumn{9}{|c|}{ Indigenous knowledge of Marind tribe } & \multicolumn{2}{|c|}{$K=32 \quad n=173$} \\
\hline & & & 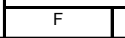 & $\%$ & $\mathrm{FL}$ & & $\%$ & $\mathrm{FL}$ & & $\%$ & FL & & $\%$ \\
\hline \multirow{4}{*}{\multicolumn{2}{|c|}{ Motivation }} & Sale & 7 & 87.51 & 31.81 & 10 & 76.92 & 33.33 & 8 & 100 & 33.33 & 25 & 78.12 \\
\hline & & \begin{tabular}{|l|} 
Prepar to pay of dowry \\
\end{tabular} & 7 & 87.51 & 31.81 & 10 & 76.92 & 33.33 & 8 & 100 & 33.33 & 25 & 78.12 \\
\hline & & \begin{tabular}{|l|} 
Without purpose \\
\end{tabular} & 1 & 12.5 & 4.54 & 0 & 0.00 & 0.00 & 0 & 0.00 & 0.00 & 1 & 3.12 \\
\hline & & $\sum F$ & 22 & & & 30 & & & 24 & & & & \\
\hline \multirow[t]{4}{*}{ Uses } & Beverage & Fresh of root & 8 & 100 & 34.78 & 13 & 100 & 32.5 & 8 & 100 & 33.33 & 29 & 90.62 \\
\hline & & \begin{tabular}{|l|} 
Fresh of stem \\
\end{tabular} & 7 & 87.5 & 30.43 & 13 & 100 & 32.5 & 8 & 100 & 33.33 & 28 & 87.5 \\
\hline & & Fresh of leaf & 0 & 0.00 & 0.00 & 1 & 7.69 & 2.5 & 0 & 0.00 & 0.00 & 1 & 3.12 \\
\hline & & $\Sigma \mathrm{F}$ & 23 & & & 40 & & & 24 & & & & \\
\hline \multirow{5}{*}{\multicolumn{2}{|c|}{\begin{tabular}{|l|} 
Variation of cultivar \\
\end{tabular}}} & The number of local name of Wati plant variations which is cultivated & 13 | & & 46.42 & 20 & & 42.55 & 11 & & 64.7 & 44 & \\
\hline & & The number of local name of Wati plant variations which is not cultivated & 9 & & 32.14 & 21 & & 44.68 & 0 & & 0.00 & 30 & \\
\hline & & The number of variations / Wati cultivar were planted & 6 & & 21.42 & 5 & & 10.63 & 5 & & 29.41 & 16 & \\
\hline & & The number of variations / cultivars were not planted & 0 & & 0.00 & 1 & & 2.12 & 1 & & 5.88 & 2 & \\
\hline & & $\Sigma \mathrm{F}$ & 28 & & & 47 & & & 17 & & & & \\
\hline \multirow{3}{*}{ Cultivation } & How to plant & In a hole & 8 & 100 & $50 \mid$ & 13 & 100 & 50 & o & $0.00 \mid$ & 0.00 & 21 & 65.62 \\
\hline & & In a cone / mound & 0 & 0.00 & 0.00 & 0 & 0.00 & 0.00 & 8 & 100 & 50 & 8 & 25 \\
\hline & & $\Sigma \mathrm{F}$ & 16 & & & 26 & & & 16 & & $7>>$ & +1 & \\
\hline \multicolumn{2}{|c|}{ Management practices } & Mulch (plant protectors with "Para-para") & 8 & 100 & 20 & 13 & 100 & 20 & 8 & 100 & 20 & 29 & 90.62 \\
\hline \multirow{5}{*}{\multicolumn{2}{|c|}{ to improve production }} & Cover crops & 8 & 100 & 20 & 13 & 100 & 20 & 8 & 100 & 20 & 29 & 90.62 \\
\hline & & \begin{tabular}{|l|} 
Protectionism soil with grass \\
\end{tabular} & 8 & 100 & 20 & 13 & 100 & 20 & 8 & 100 & 20 & 29 & 90.62 \\
\hline & & \begin{tabular}{|l|l} 
Fertilization \\
\end{tabular} & 8 & 100 & 20 & 13 & 100 & 20 & 8 & 100 & 20 & 29 & 90.62 \\
\hline & & Fence & 8 & 100 & 20 & 13 & 100 & 20 & 8 & 100 & 200 & 29 & 90.62 \\
\hline & & $\Sigma F$ & 40 & & & 65 & & + & 40 & & & 7 & \\
\hline \multirow{7}{*}{\multicolumn{2}{|c|}{$\begin{array}{l}\text { Character cultivar of } \\
\text { Wati plant }\end{array}$}} & Habitus / plant height & 7 & 87.51 & 21.87 & 13 & 100 & 20 & 8 & 100 & 16.66 & 28 & 87.5 \\
\hline & & Stem colour & 7 & 87.51 & 21.87 & 13 & 100 & 20 & 8 & 100 & 16.66 & 28 & 87.5 \\
\hline & & The length of the internode stem & 7 & 87.51 & 21.87 & 13 & 100 & 20 & 8 & 100 & 16.66 & 28 & 87.5 \\
\hline & & The size of circum stem & 4 & 50 & 12.5 & 0 & 0.00 & 0.00 & 8 & 100 & 16.66 & 12 & 37.5 \\
\hline & & The presence of spots on the stem (Lentic cell) & 7 & 87.51 & 21.87 & 13 & 100 & 20 & 8 & 100 & 16.66 & 28 & 87.5 \\
\hline & & \begin{tabular}{|l|} 
Leaf color \\
\end{tabular} & 0 & 0.00 & 0.00 & 13 & 100 & 20 & 8 & 100 & 16.66 & 21 & 65.62 \\
\hline & & $\Sigma \mathrm{F}$ & 32 & & & 65 & & & 48 & & & & \\
\hline
\end{tabular}




\section{3-1-1. Perceptions of the Wati plant (Piper methysticum Forst.) among the Marind tribe}

Plants and animals are used as symbols in ritual ceremonies among the Marind tribes. Plants are of uttermost importance in the culture of the Marind tribe, particularly several species like Wati plant, sago (Metroxylon sagu), banana (Musa x paradisiaca), taro (Colocasia esculenta), croton (in Marind language: anggin) (Codiaeum variegatum), areca nut (Areca catechu) and sugar cane (Saccharum officinarum). Pigs are the most important animals used in their culture. Those plants and animals are called custom plants and animals. Among the plants, Wati plant is outstanding. Wati should be present in every custom ceremony. Without Wati the custom ceremony cannot be carried out properly. The people from the 3 groups of the Marind tribe call Wati (Piper Methysticum Forst) a sacred thing. The Wati plant is a totem of the Ndiken, Samkakai, and Kaize family people. The totem distribution in Marind tribe is:

1.) Family Mahuze with Sago

2.) Family Gebze with Coconut and Marind's Banana

3.) Family Samkakai with Kangaroo (Saham in Marind language)

4.) Family Ndiken Kava and Ndik (bird)

5.) Family Basik-Basik with Boar and Taro

6.) Family Balagaize with Crocodile, Water, Snapper, Yellow-spotted Monitor Lizard (Varanus sp.) and Areca Palm

7.) Family Kaize with Cassowary and Fire.

This customary role was brought down to them from their ancestors. The Ndiken, Samkakai and Kaize families have a right to share information and to plant the Wati plant. Other rules relate to a form of taboo when someone goes to a Wati field. This taboo applies to both women and men, for example when women are menstruating, to women for 40 days after the delivery of a baby as well as to their husband, and to couples after sexual intercourse. They are believed to be "dirty". People who are allowed to go to the field have to be "clean". This belief is similar to the Muslim custom which bans women from praying during menstruation. 
In every ritual ceremony of Marind Beach and Marind Land Wati plants wrapped in banana leaves or Bus bark (Eucalyptus) are used (Figure 3-1) but in other customs the plants are not wrapped but lay open. The Wati plant has to be covered out of respect for a Wati totem to which the Ndiken people belong.

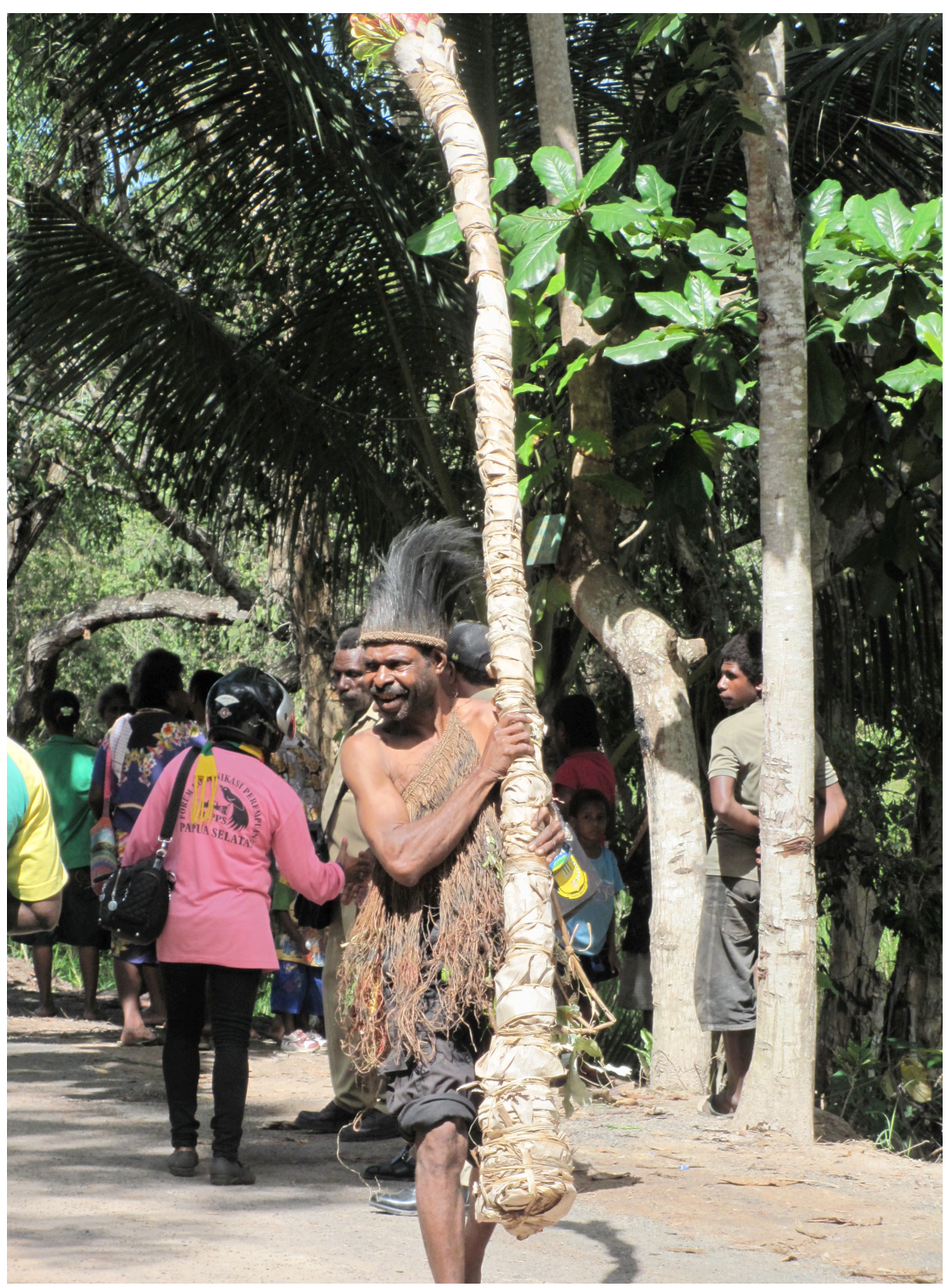

Figure 3-1. Wati wrapped in banana leaves or Bus bark (Photo by KMB Kameubun) 


\section{3-1-2. Identification and classification of Wati plants}

The knowledge of the 3 groups of the Marind tribes to recognize and to differentiate Wati plants is based on morphology and the strength of the reaction on a drink thereof.

(1). The characteristic morphology comprises habitus, height of the plant, stem color, long or short stem internodes, stem circle, spots on the stem and color of the leaves. The estimate of the length of stem internodes is based on the length of the finger and palm of an adult man. It is differentiated between "extra long size" (if the length of stem internodes is as long as a palm $( \pm 20 \mathrm{~cm})$ ), "long size" (if the length of stem internodes is as long as a middle finger $( \pm 7 \mathrm{~cm}))$ and "short size" (if the length of stem internode is as long as one phalanx of a finger (ca. $1-2 \mathrm{~cm}$ )) (Figure 3-2). The criterion "stem colour" differs among the three groups of the Marind tribes according to the person who gives the information. Accordingly, the stem colour can be black, brown, red and green. However, black, brown and red are actually metaphors for the real color that in scientific terms would be regarded as brownish red. The classification of the Wati plant based on the length of stem internodes and stem colour is shown in Figure 3-27, 3-28 and 3-29 in the Morphology section.

(2). The strength of the reaction on a drink.

The reaction on a drink is categorized from faster (1) to slow (5). Strength (1) is attributed to Wati plants with a red stem and short internodes, strength (2) to a red stem and long internodes, strength (3) to a green stem and short internodes, respectively a green to yellowish stem, strength (4) to a green stem and long internodes, and strength (5) to a green stem with the habitis of a small tree. 


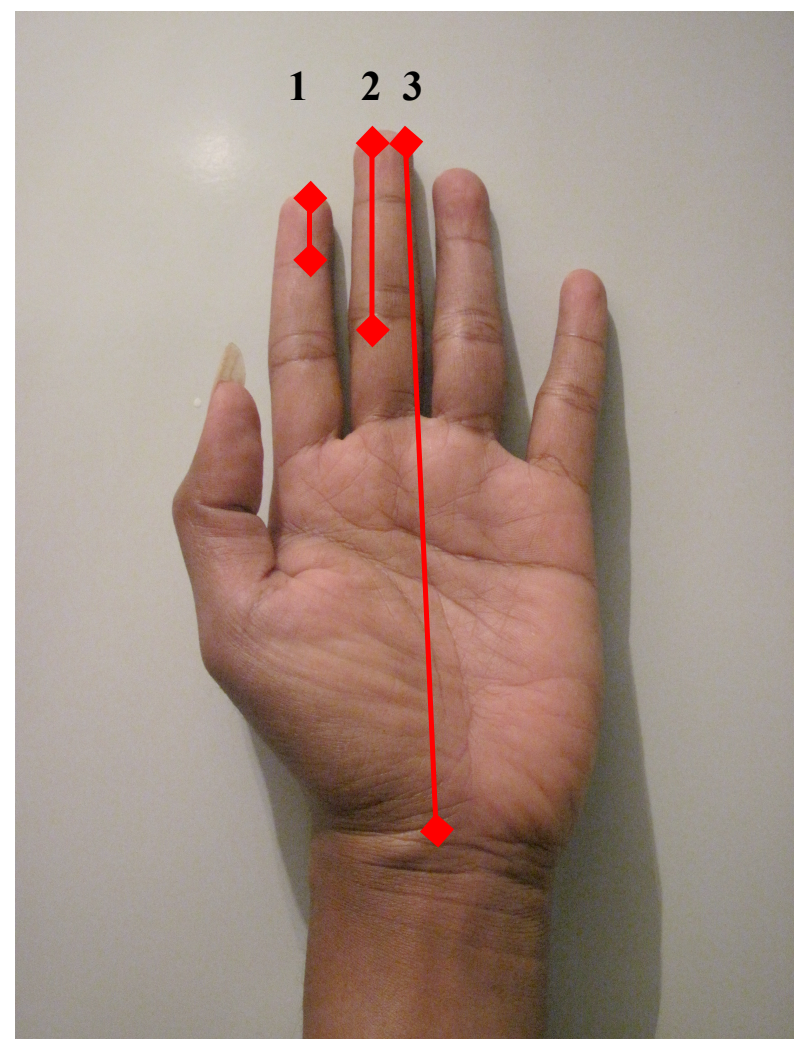

Figure 3-2. Length measurement of stem internodes of the Wati plant according to three groups of Marind tribes. Category: (1) short, (2) long, (3) extra long.

Besides local names for every variety of the Wati plant the Marind people also give different names to the different parts of the plant. These are listed in appendix 5 (Table 3-2, 3-3, and 3-4).

People of all three Marind tribes use the common name Wati, for Piper methysticum and Piper wichimannii and give specified names (vernacular names) to every variety of the Wati plant. In total, there are 70 local names of the Wati plant in 32 villages (table 3-5 appendix 5). A variety of the Wati plant can have 2 or more different local names among the people from the three Marind tribes. The difference between the names is due to the linguistic variety or the respective dialect.

From the 70 local names, people of Marind Land know 41 names. Among these 41 names 21 names are in use for cultivated Wati. People from Marind 
Beach know 21 names. Among them 11 names refer to cultivated Wati. In Marind Swamp 13 names are known which all refer to cultivated (table 3-6) (figure 3-3 ).

Table 3-6. The number of local names and plantation of Wati which are known by the respective group of Marind people.

\begin{tabular}{|c|c|c|c|c|c|c|c|}
\hline \multirow[b]{2}{*}{ category } & \multirow[b]{2}{*}{$\begin{array}{c}\text { Marind } \\
\text { Beach/ } \\
\text { Pantai }\end{array}$} & \multirow[b]{2}{*}{$\begin{array}{c}\text { Marind } \\
\text { Land/ } \\
\text { Darat }\end{array}$} & \multirow[b]{2}{*}{$\begin{array}{c}\text { Marind } \\
\text { Swamp/ } \\
\text { Rawa }\end{array}$} & \multicolumn{4}{|c|}{ identified name by Marind group } \\
\hline & & & & $\begin{array}{c}\text { Darat } \\
+ \\
\text { Pantai }\end{array}$ & $\begin{array}{c}\text { Darat } \\
+ \\
\text { Rawa }\end{array}$ & $\begin{array}{c}\text { Pantai } \\
+ \\
\text { Rawa }\end{array}$ & $\begin{array}{c}\text { Darat } \\
+ \\
\text { Pantai } \\
+ \\
\text { Rawa }\end{array}$ \\
\hline identified & 21 & 41 & 13 & 4 & - & - & - \\
\hline cultivated & 11 & 20 & 13 & & & & \\
\hline $\begin{array}{c}\text { identified } \\
\text { but not } \\
\text { cultivated }\end{array}$ & 10 & 21 & 0 & & & & \\
\hline
\end{tabular}

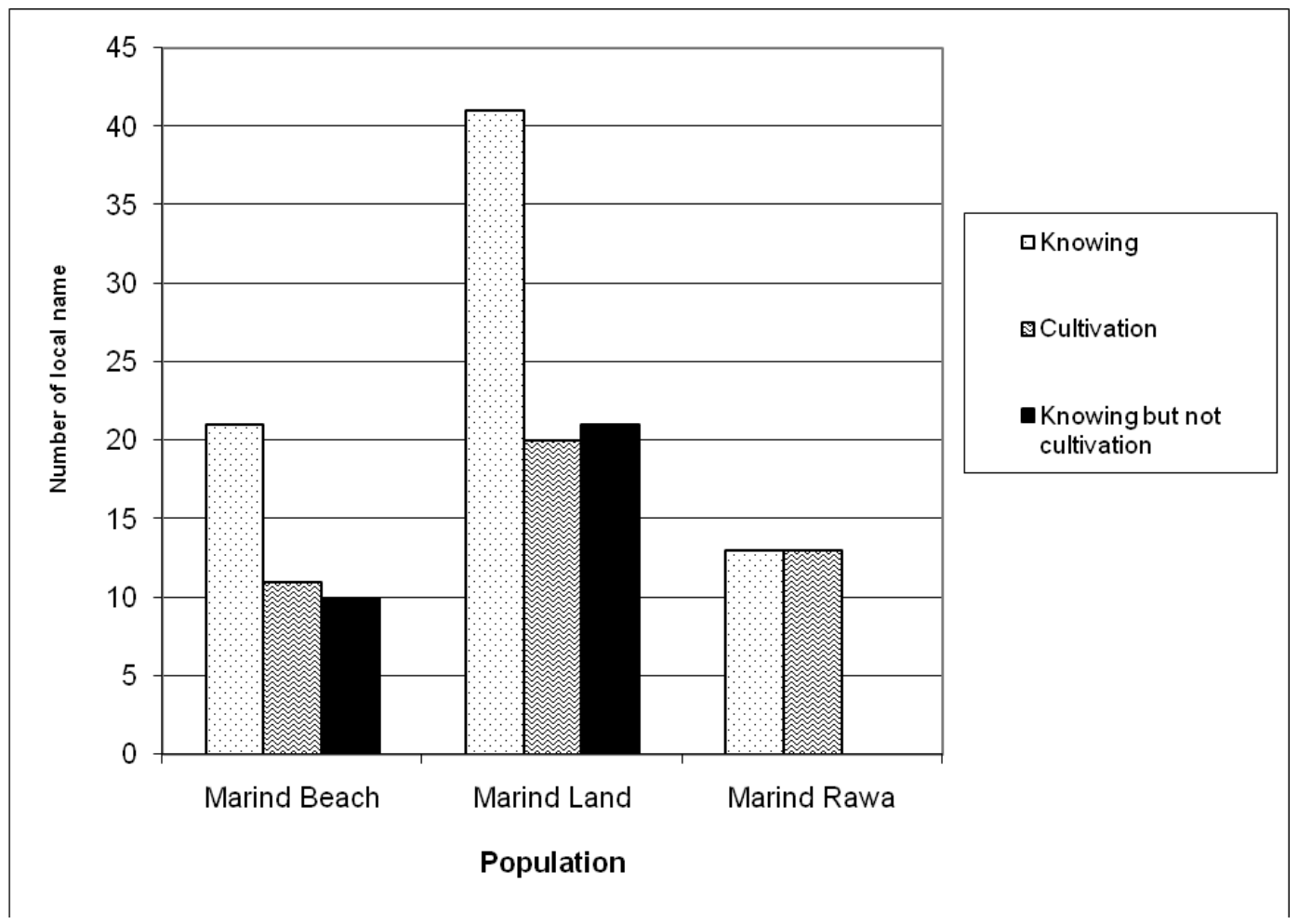

Figure 3-3. Number of local names of Wati plant which are known by the groups of Marind tribe. 


\section{3-1-3. A guide to determination of Wati according to traditional knowledge}

Local people differentiate the varieties of Wati by the following morphological characteristics, here compiled as an identification key:

1a. Tree habitus, height is more than $3 \mathrm{~m}$ with green stem...................... Marub

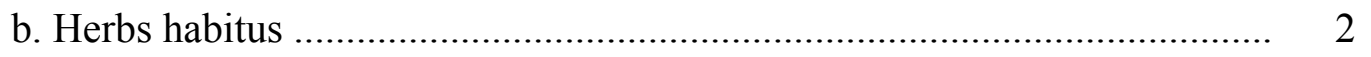

2a. Brown stem, short stem internode is $2-6 \mathrm{~cm}$, height of the plant is less than $1 \mathrm{~m}$..................................................... Sipul

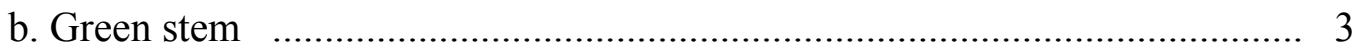

c. Black stem, long internode .............................................. Donggar, Purima dan Thomur

d. Yellow stem, short internode ...................................................... Babin

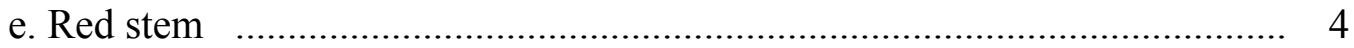

3a. Lenght of stem internode is $4-14 \mathrm{~cm}$, height reaches $2 \mathrm{~m} \ldots \ldots \ldots \ldots \ldots \ldots \ldots \ldots . . .5$

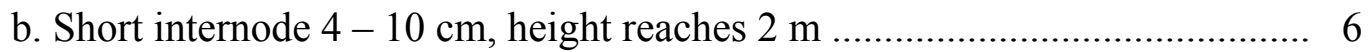

4a. Lenght of stem internode is $2-11 \mathrm{~cm}$, height reached $2 \mathrm{~m}$ more Palima dan Parima

b. Short internode is $1-4 \mathrm{~cm}$, height less then $1 \mathrm{~m}$............... Babid dan Babind 5a. Spotted stem Kuas nggap, Prahteh dan Otakon b. spotlesss stem .....................................eve qiwasom, Sipur, Kambiru, Besal, Yone, Wati, Urawe, Safurawe, Sakaro, dan Amnanggip bolawe 6a. Spotted stem Munana, Benetre b. spotlesss stem Tuband, Meve patul, Sah ulawe, Ulawe, dan Sah walawe 


\section{3-1-4. Utilization of the Wati plant among the three Marind tribes}

The Wati plant is used among the three goups of Marind tribes in religious ceremonies, social life and custom. The Wati plant can be processed for beverage. The beverage is called "heritage drink" and drunk in every custom ceremony. Another utilization of the Wati plant is in medicine (in chapter 3 part 3-1-4-1).

\section{3-1-4-1. Processation of the Wati plant for producing a beverage and medicine.}

Processation to beverage is the same among the people in the three groups of the Marind tribe but the application in medicine depends on each people's experiences (Table 3-7). 
Table 3-7 The parts of Wati used and processed for beverage and medicine.

\begin{tabular}{|c|c|c|c|}
\hline $\begin{array}{l}\text { Parts of } \\
\text { the plant }\end{array}$ & Use & Processing & $\begin{array}{c}\text { Knowledge about } \\
\text { it among Marind } \\
\text { tribe groups }\end{array}$ \\
\hline Root & $\begin{array}{l}\text { - main ingredient of the } \\
\text { beverage }\end{array}$ & $\begin{array}{l}\text { Root and stem are cleaned up from soil upwards and chewed until } \\
\text { much liquid is produced in the mouth. It is spitted on a spot created } \\
\text { before (Figure 3-4). This process is carried out until the specific taste is } \\
\text { generated. The chewing and salivation product is spitted out and } \\
\text { filtered by using natural tools such as coconut fibers and put in the spot } \\
\text { (figure 3-5). After that the Wati beverage can be drunk. }\end{array}$ & $\begin{array}{l}\text { - Marind Beach, } \\
\text { Land, Swamp }\end{array}$ \\
\hline Stem & $\begin{array}{l}\text { - main ingredient of the } \\
\text { beverage } \\
\text { - Medicine for cough } \\
\text { - Medicine for wound healing, } \\
\text { the wound being due to slaps } \\
\text { with a stick } \\
\text { - Medicine for dammages due } \\
\text { to motorcycle exhaust gases }\end{array}$ & $\begin{array}{l}\text { - medicine for cough: the stem is chewed up and the essence from } \\
\text { the stem is sucked by the patient. } \\
\text { - medicine for wound healing: the stem is chewed up until being } \\
\text { smooth (Figure 3- 6) and then placed on the wound (Figure 3-7). }\end{array}$ & $\begin{array}{l}\text { - Marind Beach, } \\
\text { Land, Swamp }\end{array}$ \\
\hline Leaf & $\begin{array}{l}\text { - Medicine for treating insect } \\
\text { stings, Kelabang. } \\
\text { - Medicine for wound healing, } \\
\text { the wound being due to stings } \\
\text { of Bambit, Duri, or Pari fish } \\
\text { species. }\end{array}$ & $\begin{array}{l}\text { Tobacco and ginger are given into the leaf. Then the Wati leaf is rolled. } \\
\text { The roll is cooked with coconut milk until boiling. Still warm it is } \\
\text { placed on the wound. }\end{array}$ & - Marind Beach \\
\hline
\end{tabular}




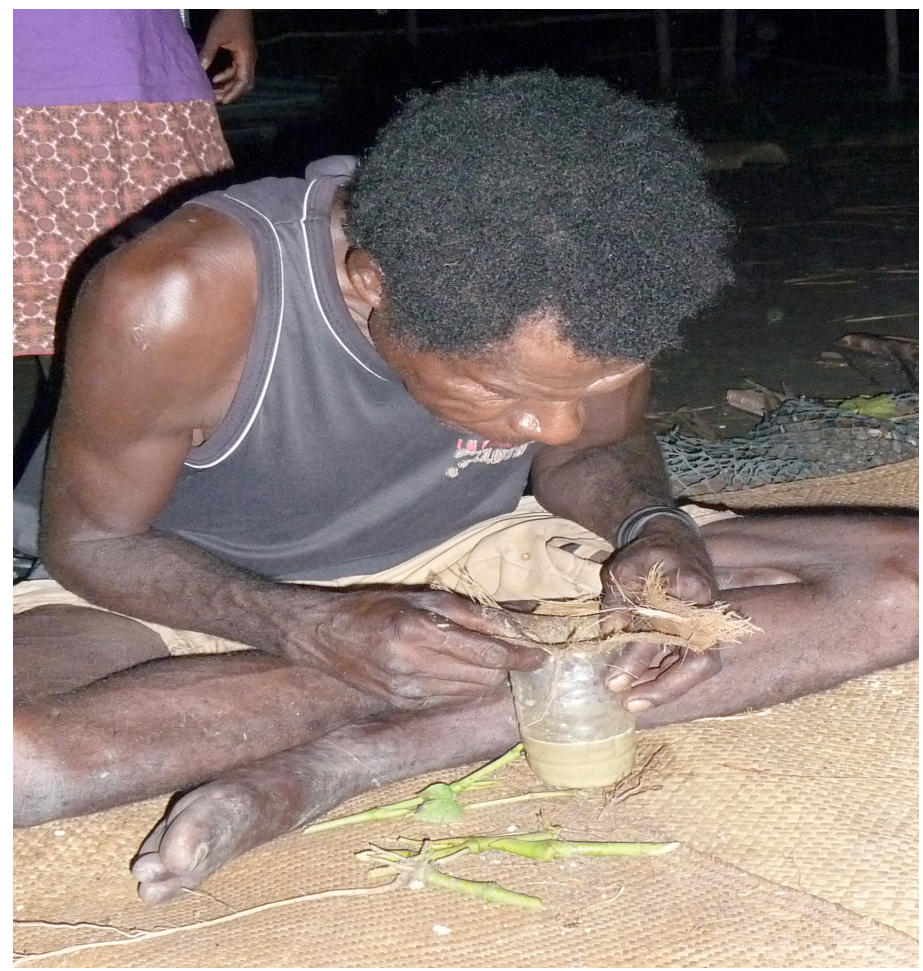

Figure 3-4. Chewing and filtration of roots and stems of the Wati plant by Marind people (Photo by KMB Kameubun).

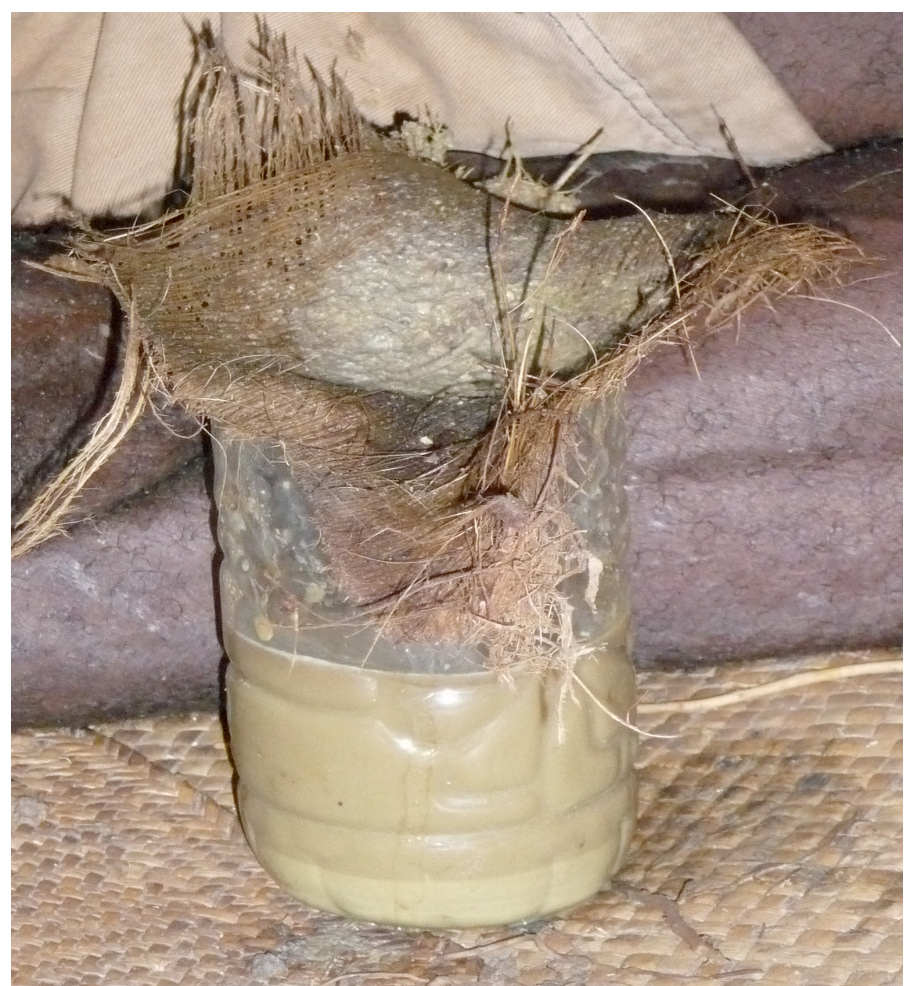

Figure 3-5. Chewing product from roots and stems of the Wati plant (Photo by KMB Kameubun). 


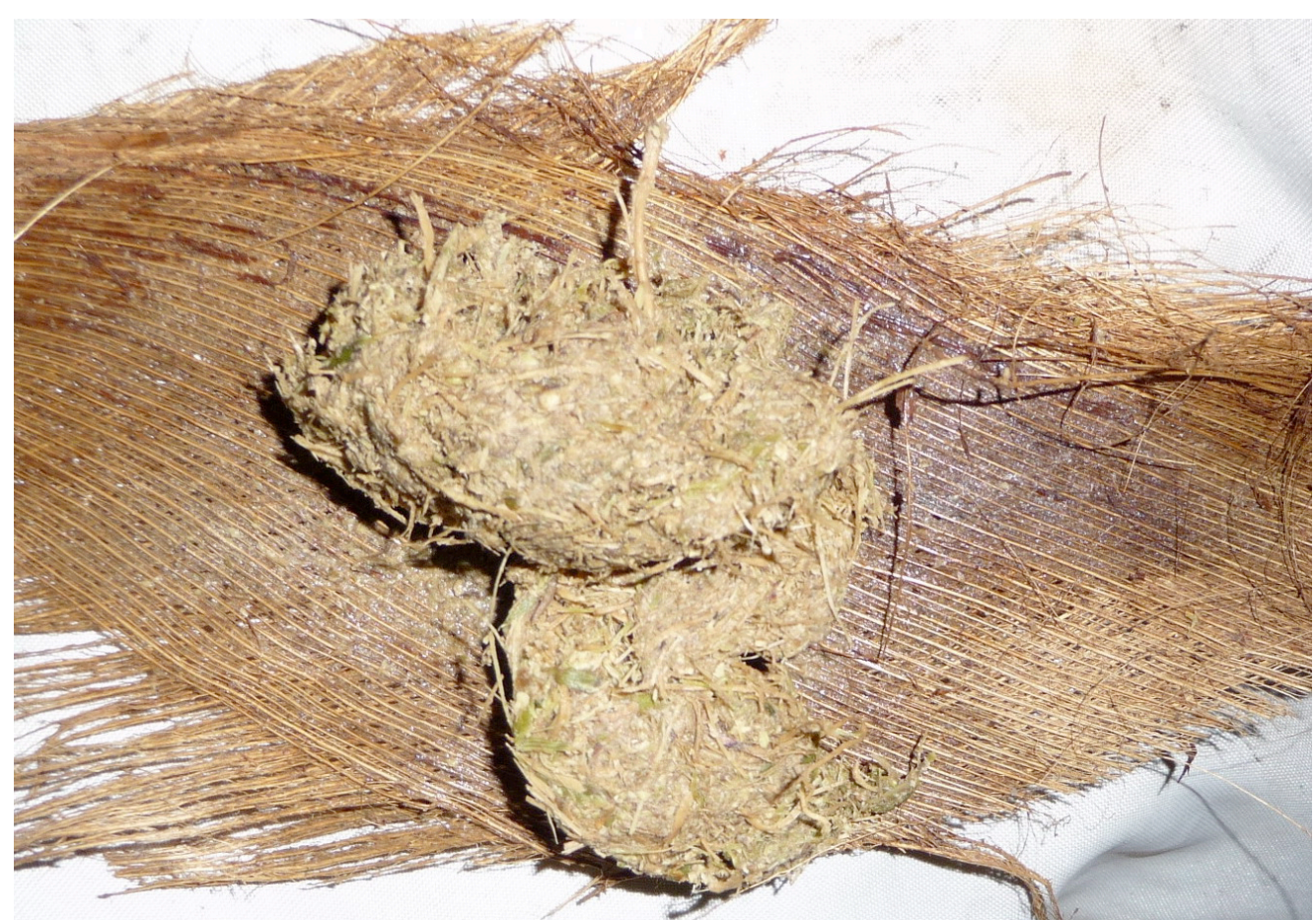

Figure 3-6. The chewed essence from the stems (Photo by KMB Kameubun).

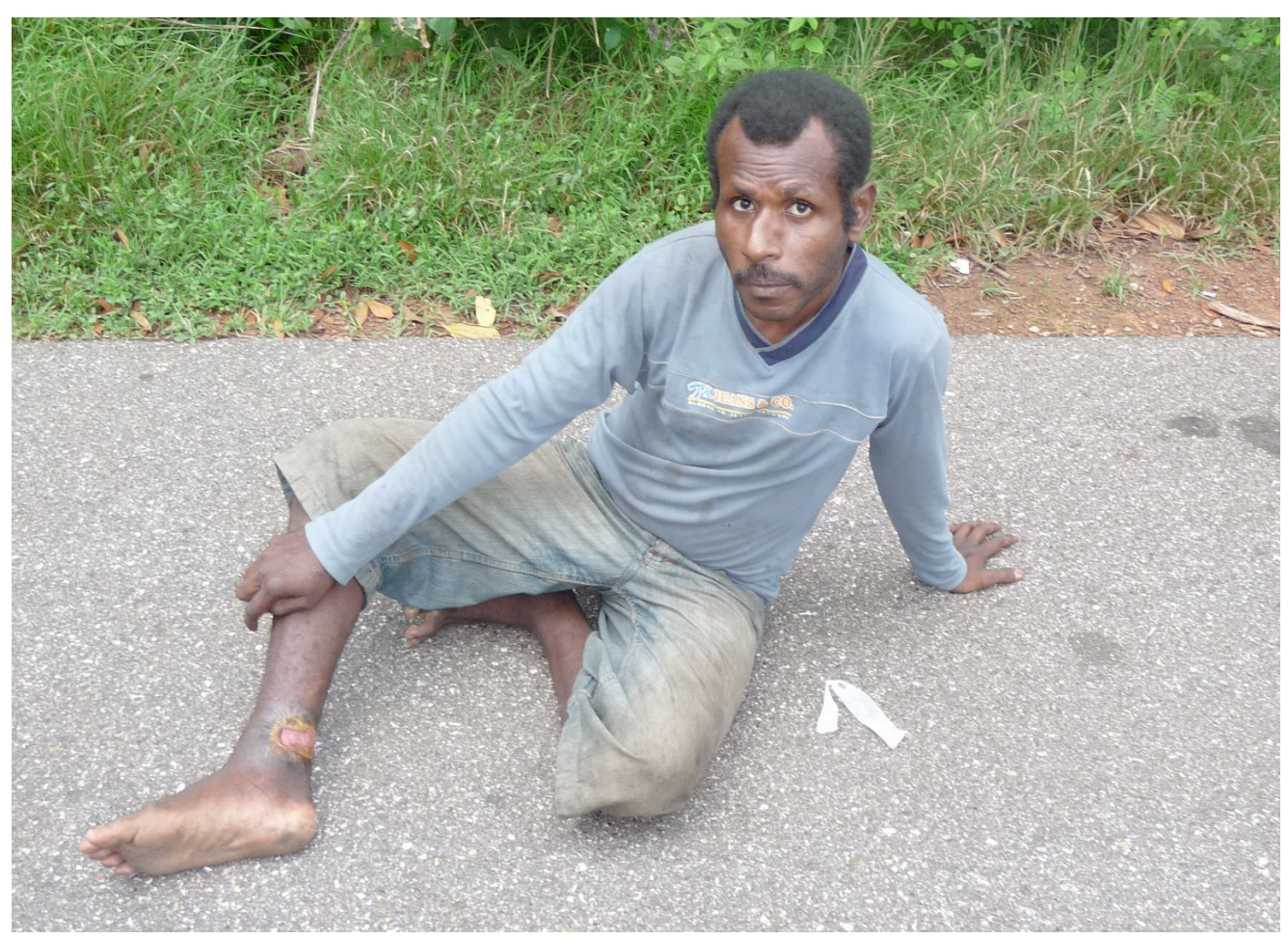

Figure 3-7. Experience by Yanuarius Gebze from Wasur village (Marind Land/Marind Darat/degh). He used the stem of the Wati plant to cure the dammages caused by motorcycle exhaust gases (Photo by KMB Kameubun). 
All cultivars of the Wati plant can be processed for beverage. From shrubs and plants stems and roots can be used. From Wati plants with the habitus of a small tree only the roots are used for beverage. This chewing of the root or the stem can be carried out by everyone, not only by women but also by men, by the young or the old (above the age of ca. 20 years), with the exception of pregnant women. A person unable to drink the Wati beverage during a ritual ceremony just sticks a finger into the Wati beverage in a cup. This is considered equivalent to drinking the Wati beverage. The effect of the Wati beverage consists in muscle relaxation. In consequence, these people are unfit for other activities besides sleeping. This effect has been called Wati intoxication. To overcome this intoxication sweet food like sugar cane, banana, sweet coconut fibers are eaten. Coconut water serves for the neutralization of food and drink.

The traditional cup for the Wati beverage cup as used traditionally by the Marind people in custom ceremonies of ancestor worshipping is a coconut shell. It is called "manggon". The diameter of the cup is ca. 5-6 cm (Figure 3-8).

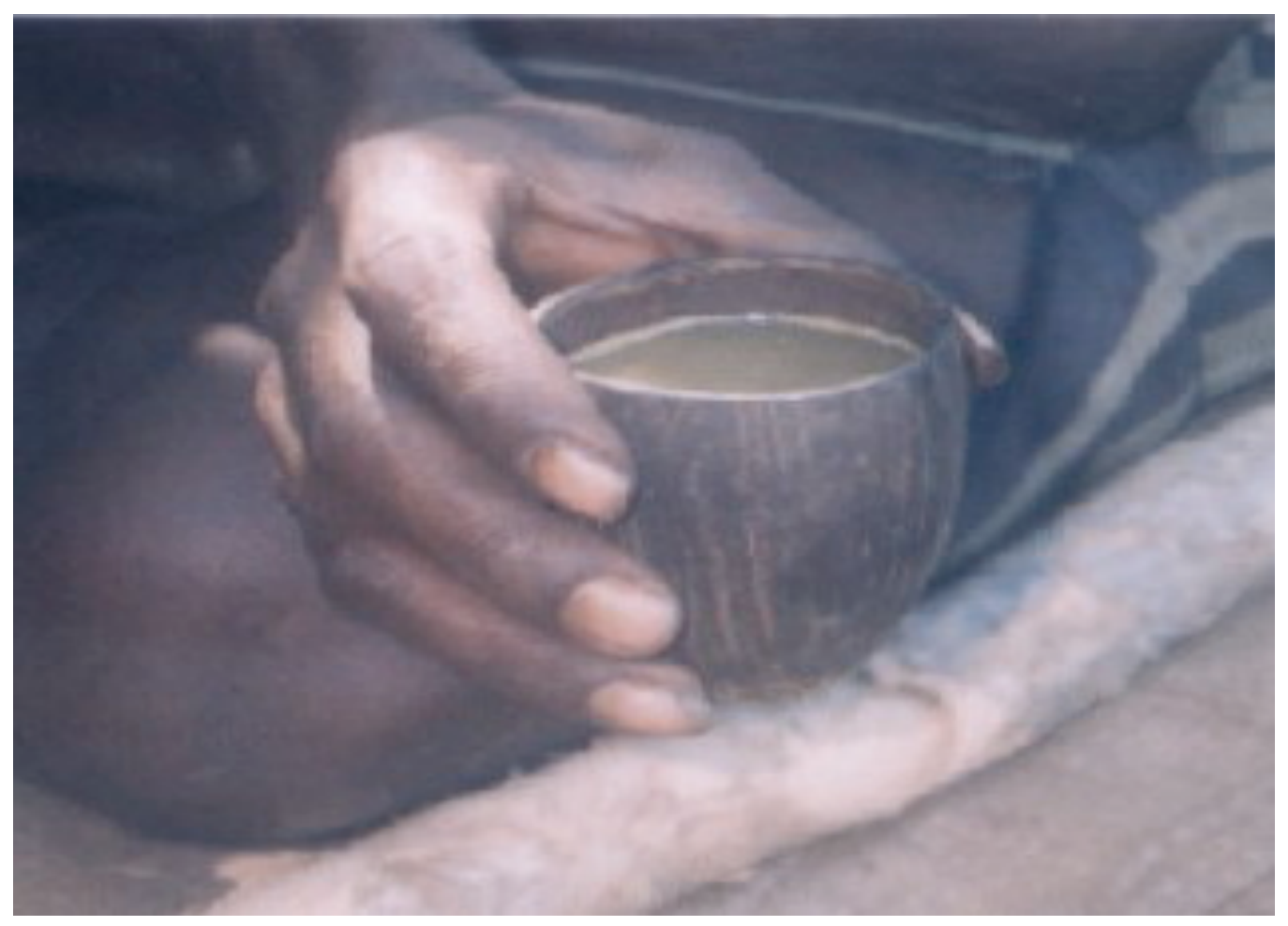

Figure 3-8. The cup for the Wati beverage (Marind language: Manggon) is made from a coconut shell. 


\section{3-1-4-2. Use of the Wati plant in ritual ceremonies}

The Wati plant is used in every ritual ceremony such as: (1). dowry (Marind language: Dahud/ dahun/ nai kere/ pemer), (2). wedding ceremony, (3). death ceremony, (4). Conclusion of peace after fights between the people, (5). Pig party (in Marind language: Basik anggai, sawo, mboyo). This refers to a celebration in which a pig is sacrified in the honour of a person that contributed. Girls wear earrings, boys wear traditional dresses. (6) as a reward, (7). religious festivity, such as baptism, communion in the catholic belief, grant of the Krisma/ Sidi sacrament (Christian), Chrismas, Easter, (8). electing or inaugurating the traditional chief, (9). A person's appointment as a traditional child, (10), welcoming of the young people having left the village for a long time.

Not all of these 10 ritual ceremonies are custom in all groups of the Marind tribe. People from Marind Beach (Marind Pantai/Marind dufh) perform 7 out of 10 of these rituals, which are : (1), (2), (3), (4), (5), (6) and (7). People from Marind Land (Marind Darat/Marind degh) perform 9 out of 10 rituals, which are: (1), (2), (3), (4), (5), (6), (7), (8) dan (9). People from Marind Swamp (Marind Rawa/Marind bob) perform 8 out of 10 ritual, which are: (1), (2), (3), (4), (5), (6), (7), and (10). Several rituals are performed identically but there are different procedures in each people of the 3 groups of Marind tribes. The traditional rituals are explained in Appendix 10 in CD.

\section{3-1-5. Cultivation (planting, maintenance, fertilization and harvesting) of the Wati plant according to traditional knowledge}

People from all three group of the Marind tribe cultivate Wati plants in their gardens. Planting is the same among Marind Land (Marind Darat / Marind degh) and Marind Beach (Marind Pantai / Marind duft) people, but among Marind Swamp (Marind Rawa / Marind bob) people it is different. These differences lie in the planting method, but not in the care, cultivation and harvest. 
The distance between house and garden varies between $5 \mathrm{~m}$ and $1 \mathrm{~km}$ from the house. Gardens use to be in the back of the house or on the lot. The rationale for having gardens in the forest far from the village is that not many people know about it. There are problems of other people stealing this plant because the owners do not very often take care of their garden. The Marind people have the belief that this plant should be planted hidden from the sight of other people. This plant should not be seen by many people, as its growth will be affected resulting in less fertility and in a slow dying off.

Decorational plants in Wati fields comprise varieties of Croton (Codiaeum Variegatum) (Marind Language: Aggin). They are planted around the Wati field. Croton is unique because their variety in leaf shape and colour. This causes people to recognize the gardens from the distance in every Marind village (Figure 3-9). This bestows a specific characteristic to a Wati plant garden. Other species planted around and inside the Wati field are custom plants (usually referred as ornamental plant in Kava plantation) in the same plantation in a form of multiple cropping whose functions are to give shade, creating cool micro-climate and protecting the Kava from strong wind. Kava have to be protected against those elements as it is fragile against them. Strong wind and bright sunlight could cause the plant to wither. Once it withers, it is unlikely to flourish again, for that reason it will perish. These plants are always present in ceremonies. 


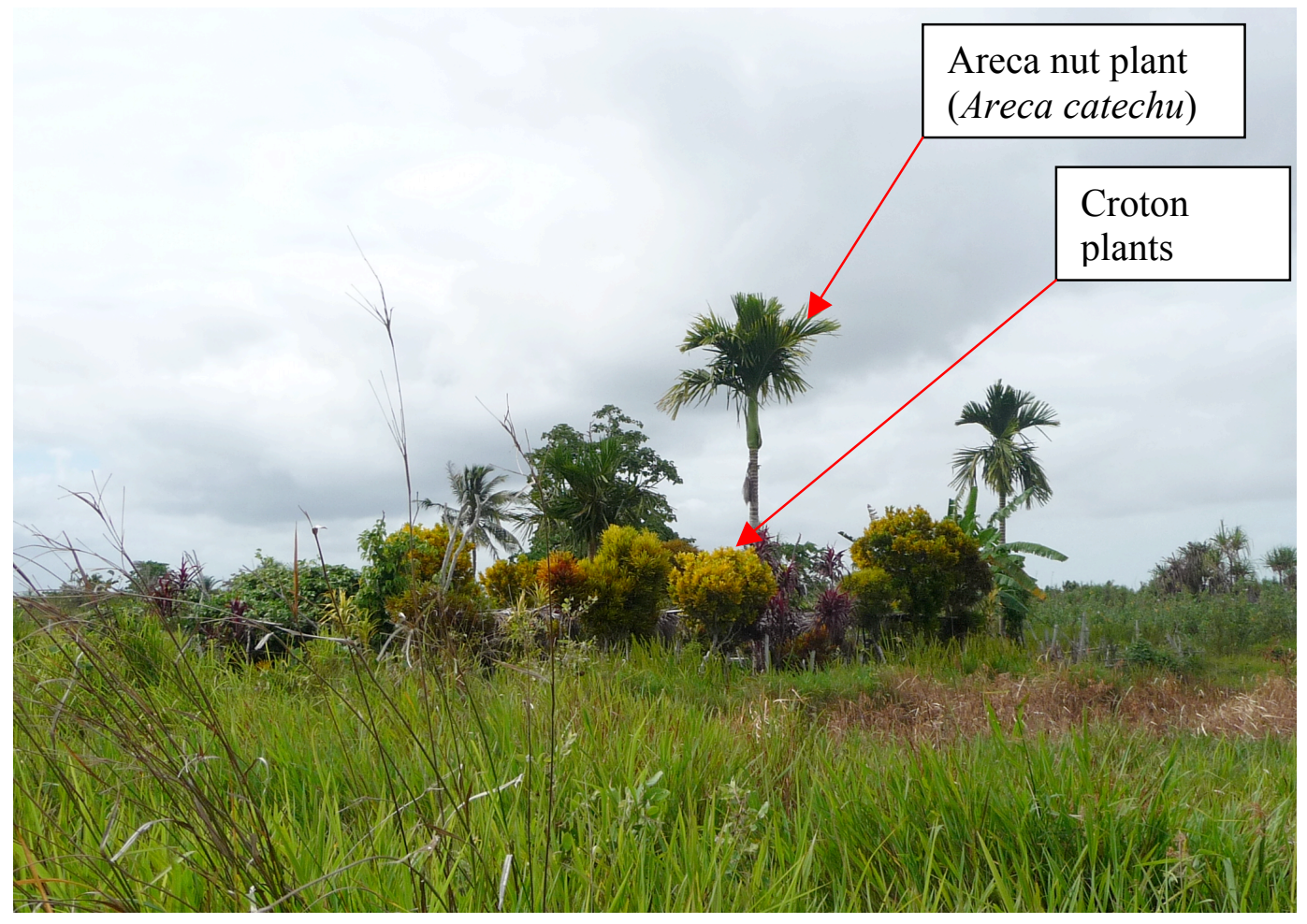

Figure 3-9. Wati gardens can be seen from the distance. This garden is surrounded by decorational plants (Photo by KMB Kameubun).

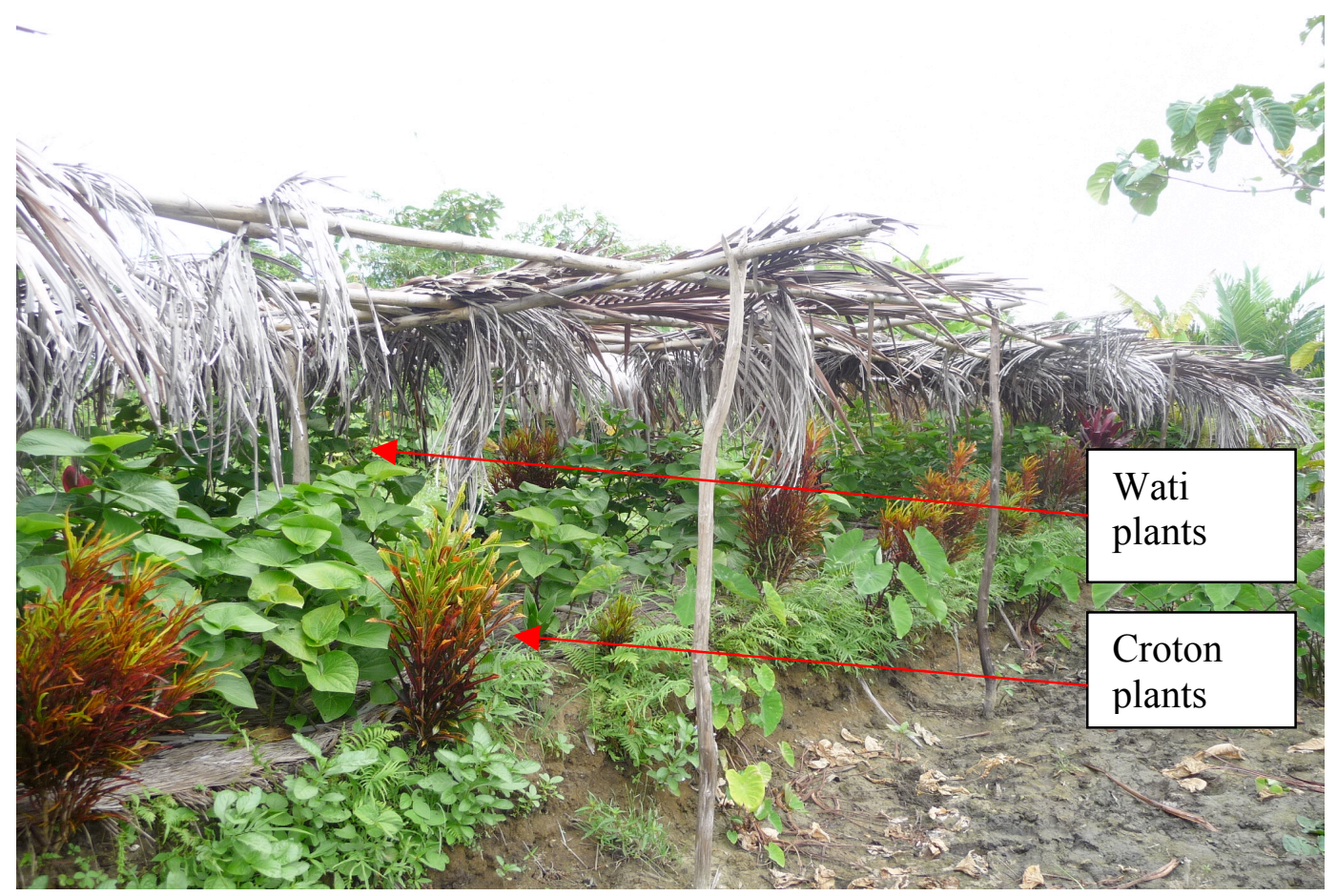

Figure 3-10. Wati garden seen from close up (Photo by KMB Kameubun) 
The reproduction of Wati plant is achieved by cutting the stem. It has 1 or 2 nodes per internode. Long stem internodes have one internode per stem, short stem internodes usually have 2 nodes per internode. Long stem internodes need only 1 node because if it is planted deep in the ground there is still space for a node to grow up to a bud. This bud will eventually grow and evolve until the plant has reached a height of $2 \mathrm{~m}$. In contrast, short stem internodes usually have two stem internodes. When they are planted in the soil one of the buds nodes is covered by the soil and thus has no space for growing up to a bud. So another stem internode is needed for growing up to a bud from the node and for developing until the plant has reached a height of $2 \mathrm{~m}$.

There are two ways of planting, a direct and an indirect way. The direct way consists in stem assimilation. Herein it is planted directly in the ground (Wambada in Marind language). The indirect way refers to growing in a seedbed. Thereafter it is replanted into a prepared field.

\section{3-1-5-1. Seedbed}

Seedbeds comprise small fields, ca. $40 \times 50 \mathrm{~cm}$. The aim is to stimulate a quick growth of roots and bud. Stem assimilation is carried out in parallel. The stem is positioned horizontally and bud nodes are facing upward. Thus the bud is able to grow out from the node. Thereafter it is covered by soil, ca. $0.5-1 \mathrm{~cm}$. When the bud grows up the assimilation stem is replanted into a large field. Bud and root usually need to grow about one week. Seedbeds require locations without direct sun radiation. Usually, seedbeds are entirely protected by a roof made from sago leaves or the bark of Eucalyptus tree.

\section{3-1-5-2. Planting}

The seed of Wati plants from the seedbed is transfered to a lot (in Marind language: Wambada) for planting. It may range from $2 \times 2 \mathrm{~m}$ to $3 \times 5 \mathrm{~m}$. This measurement is not unvariably but depends on the number of seeds to be planted. 
Wati planting Wati is the same among Marind Land (Marind Darat / Marind degh) and Marind Beach (Marind Pantai / Marind dufh) people. But it is realized in a different way by Marind Swamp (Marind Rawa / Marind bob) people.

People from Marind Swamp (Marind Rawa / Marind bob) plant the Wati stem having buds in the soil and pile up mud in a cone-like manner (Figure 3-11). The idea is to create a soil stack. The cone-like shape serves to hinder that the Wati plant is coverd by stagnant water. Thus it can develop many roots and is easy to harvest. The planting method of Marind Beach (Marind Pantai/Marind dufh) and Marind Land (Marind Darat/Marind degh) people consists in planting them into a hole with a diameter of ca. $15 \mathrm{~cm}$ and a depth of ca. $10 \mathrm{~cm}$ depth in a field (in Marind language: Wambada). The hole serves to absorb water when being watered.

In each hole or cone usually 2 to 4 assimilation stems are set depending on the length of the internodes. The stem position can be vertical, oblique or transversal (Figure 3-12). The distance between holes or cones in the field is about $50 \mathrm{~cm}$. The leaves need space wide enough to get optimal sunlight to perform photosynthesis. Thus the spacing of $50 \mathrm{~cm}$ is ideal for Wati or Kava.

The number of cut stems and their spacing is the same among the 3 groups in Marind tribes. 

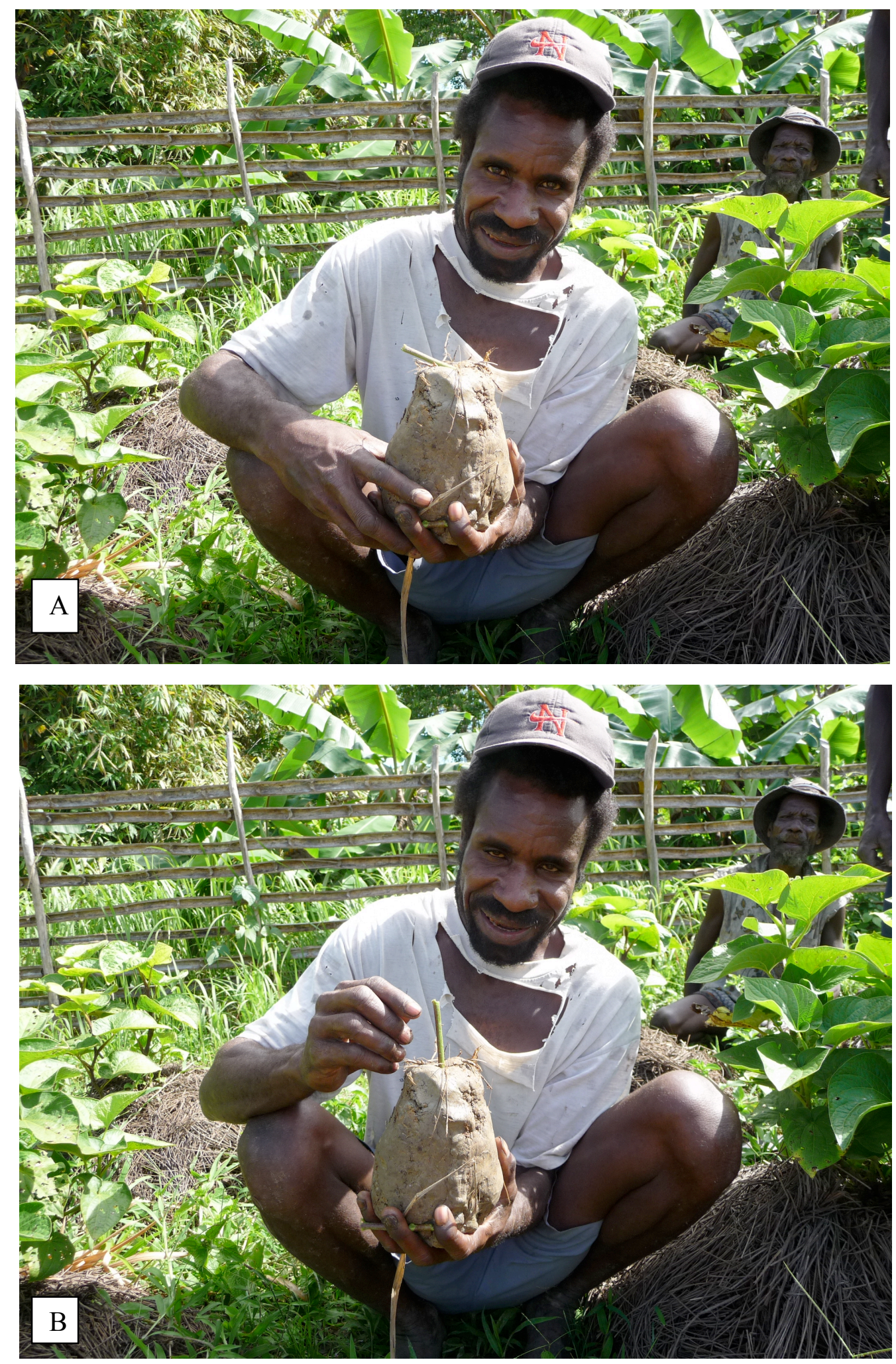

Figure 3-11. Planting position of Wati; (A). oblique (B). vertical according to Marind Swamp (Marind Rawa) people (Photo by KMB Kameubun) 


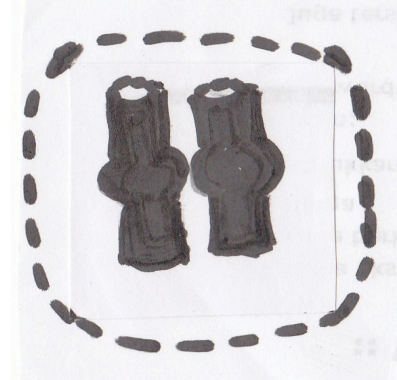

(A)

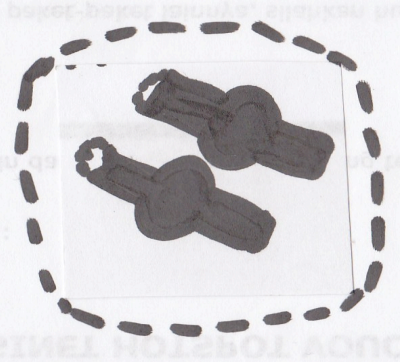

(B)

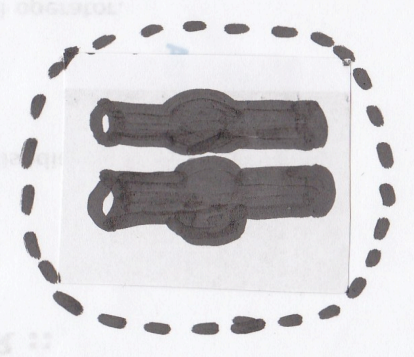

(C)

Figure 3-12. Planting position of Wati; (A). vertical, (B). oblique, (C) transversal according to Marind Beach (Marind Pantai) and Marind Land (Marind Darat) people (Sketch by KMB Kameubun).

After cutting stems are placed in the holes or cones. They are covered with dry leaves of Alang-alang (Imperata cylindrica) grass and other grasses. Leaves of Alang-alang (Imperata cylindrica) grass are arranged in parallel to the longside of the field among Marind Beach (Marind Pantai) and Marind Land (Marind Darat) people (Figure 3-13). Marind Swamp (Marind Rawa / Marind bob) people do it in a different way (Figure 3-14). They are covered with dry leaves of Alang-alang or grasses as a protection against radiation or (in Marind language: gogo) in order to keep the humidity, to decrease the sun heat and to reduce the evaporation that could dry out the soil. 


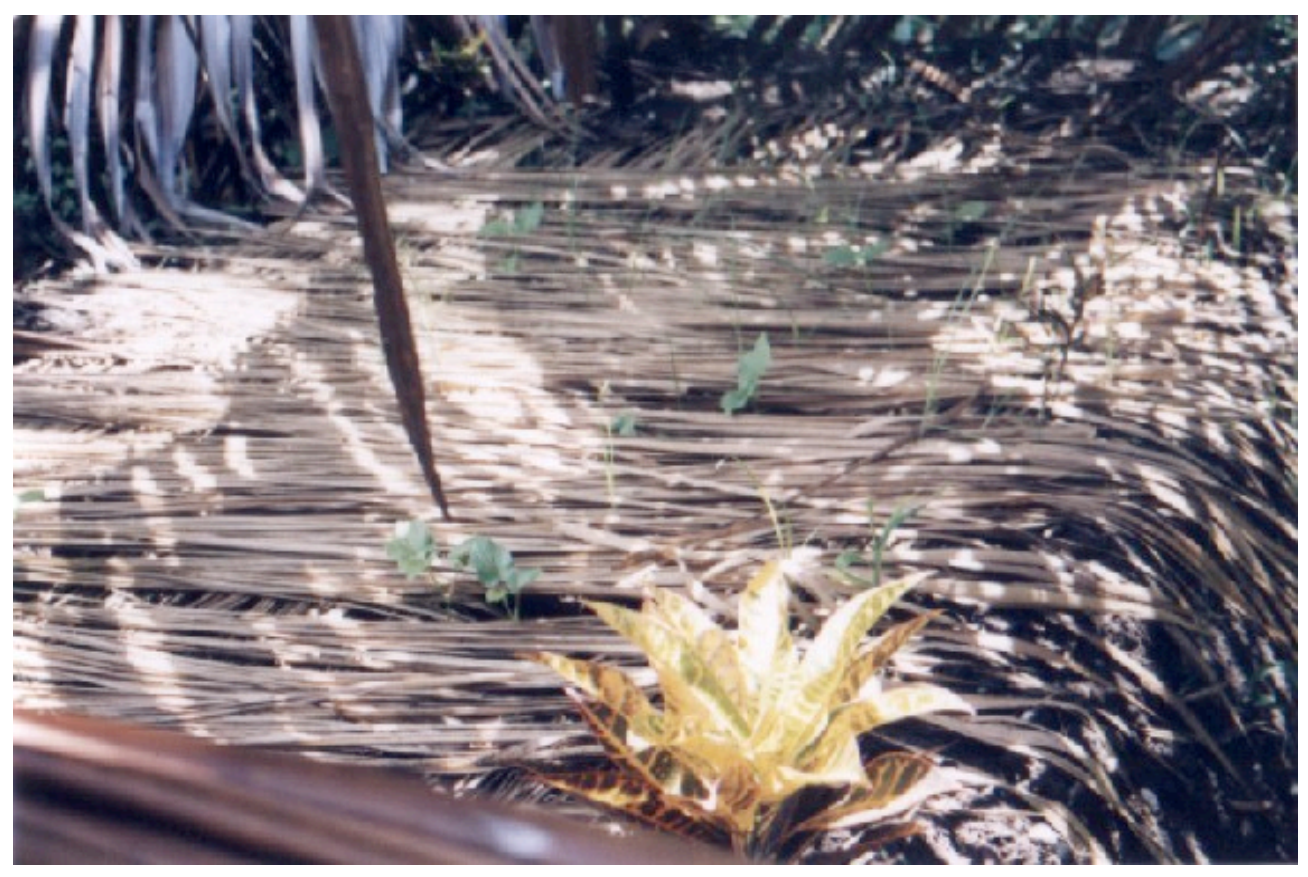

Figure 3-13. Covering with dry Alang-alang (Impereta cylindrica) leaves is the plantation method of Marind Land (Marind Darat / Marind degh) and Marind Beach (Marind Pantai / Marind dufh) people (photo by KMB Kameubun).

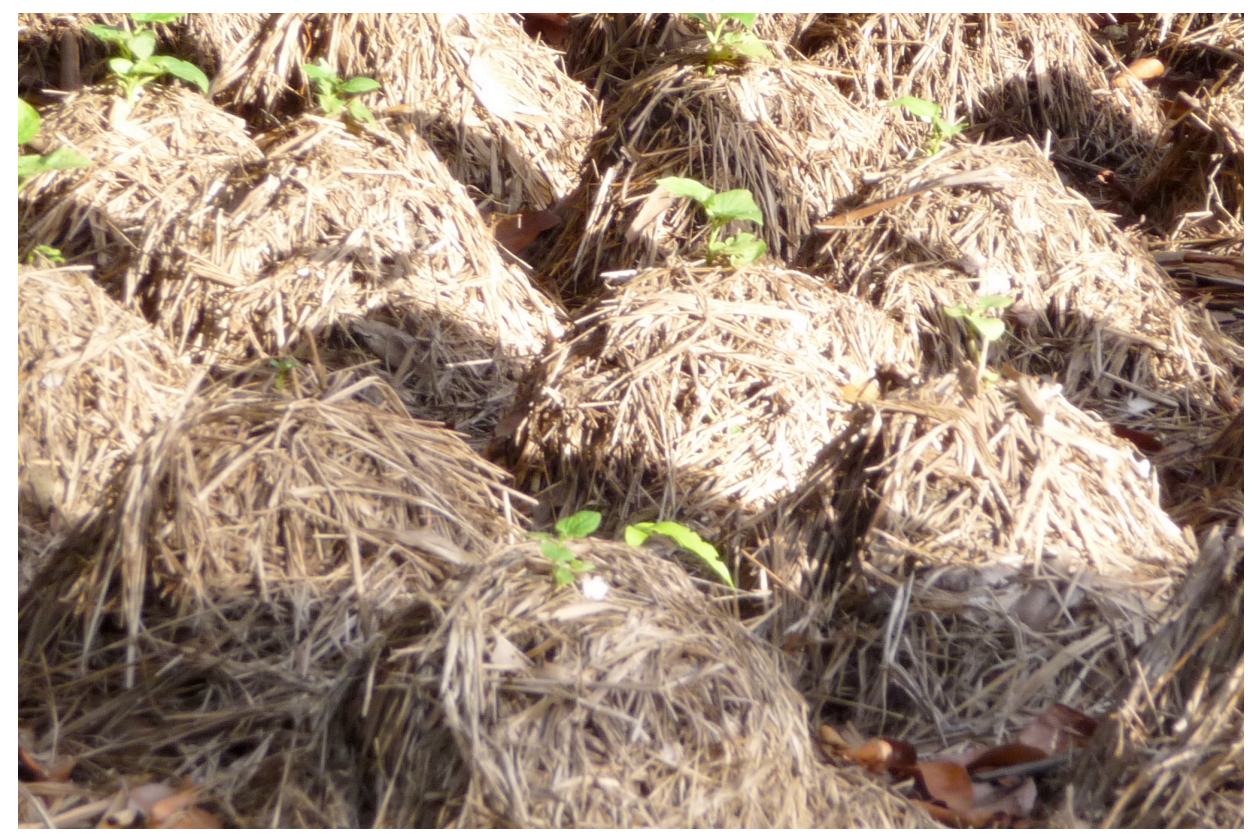

Figure 3-14. The soil or mud where they plant Wati is protected with dry grass, as done by Marind Swamp (Marind Rawa / Marind bob) people. (photo by KMB Kameubun) 
In dependence whether the dry or the rainy season is to come, the lot with Wati plants is protected (Gogo in Marind language) by so-called "Para-para" and "Rumah anakan" as a roof. Marind people use the leaves of coconut (Cocos nucifera) or sago leaves (Metroxylon sagu) from the order Arecaceae (palmpaleman) for "Para-para" and "Rumah Anakan" which function to protect plants from the heat of direct sunlight and holding or reducing the amount of rainwater falling on crops which might damage Kava's growth. Coconut leaves and sago leaves are selected as protection for Kava because the leaf blade can absorb heat, hold water (leaves could not absorb a lot of water) and can last about 3-6 months. The height of a Para-para ranges from 1.5 to $2.5 \mathrm{~m}$ from the ground (Figure 3-15 and 3-16). In Rumah anakan Alang-alang grass (Imperata cylindrica) is used (Figure 3-17).

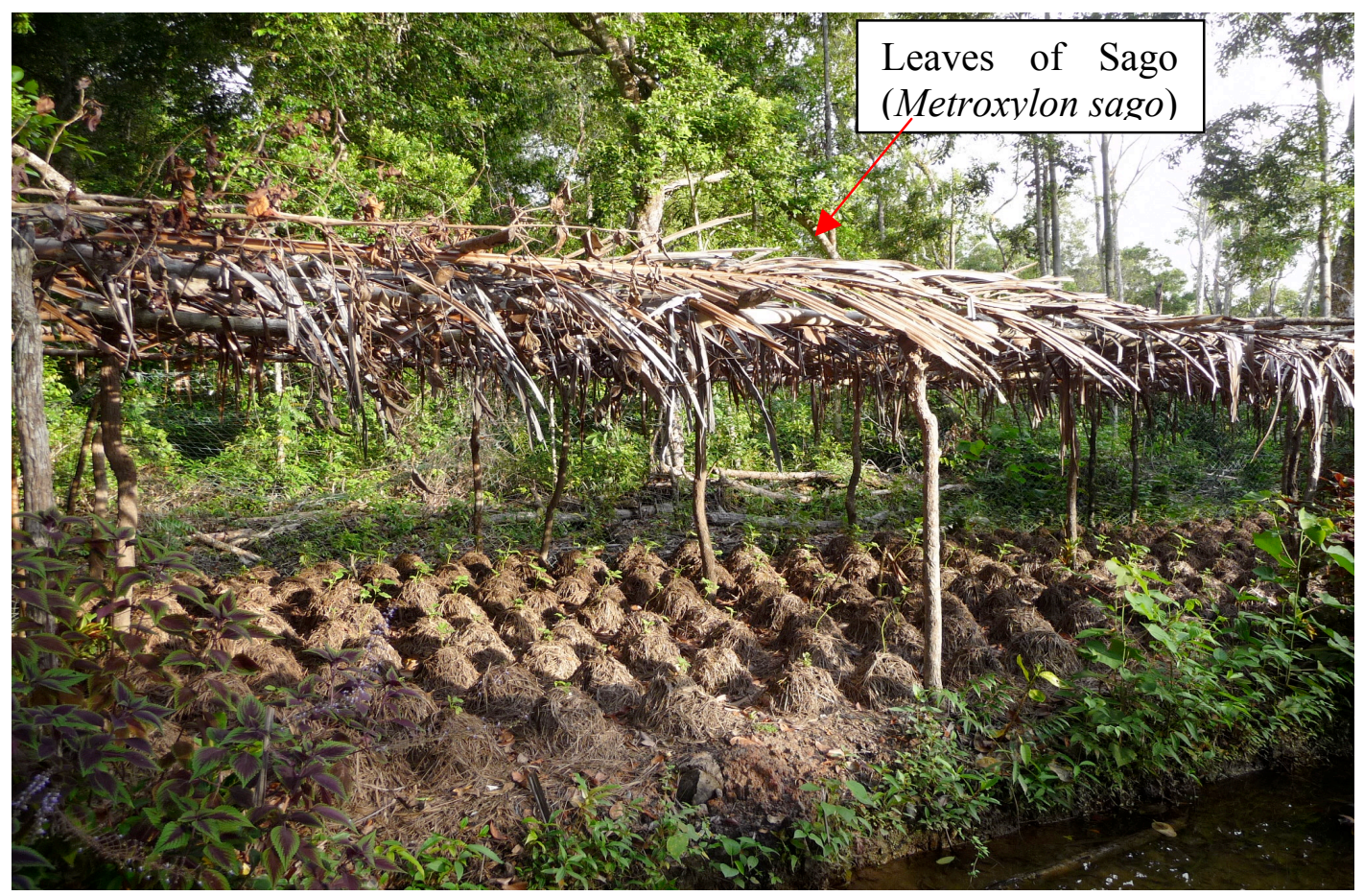

Figure 3-15. "Para-para" is a sheltered lot of Wati plants of people of Marind Swamp (Marind Rawa) (photo: KMB Kameubun). 


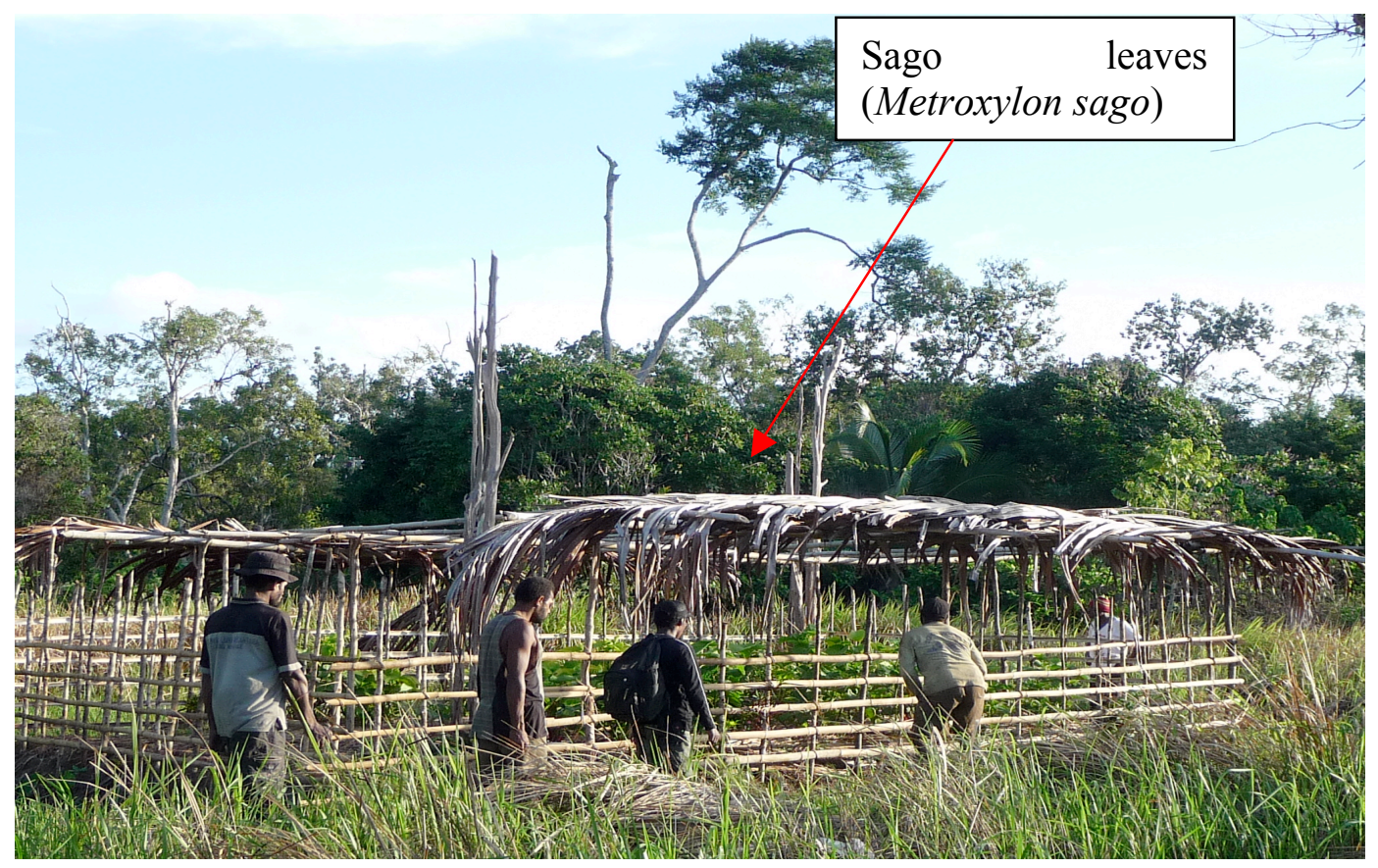

Figure 3-16. "Para-para" is a sheltered lot of Wati plants by people of Marind Beach (Marind Pantai) and Marind Land (Marind Darat) (photo by KMB Kameubun).

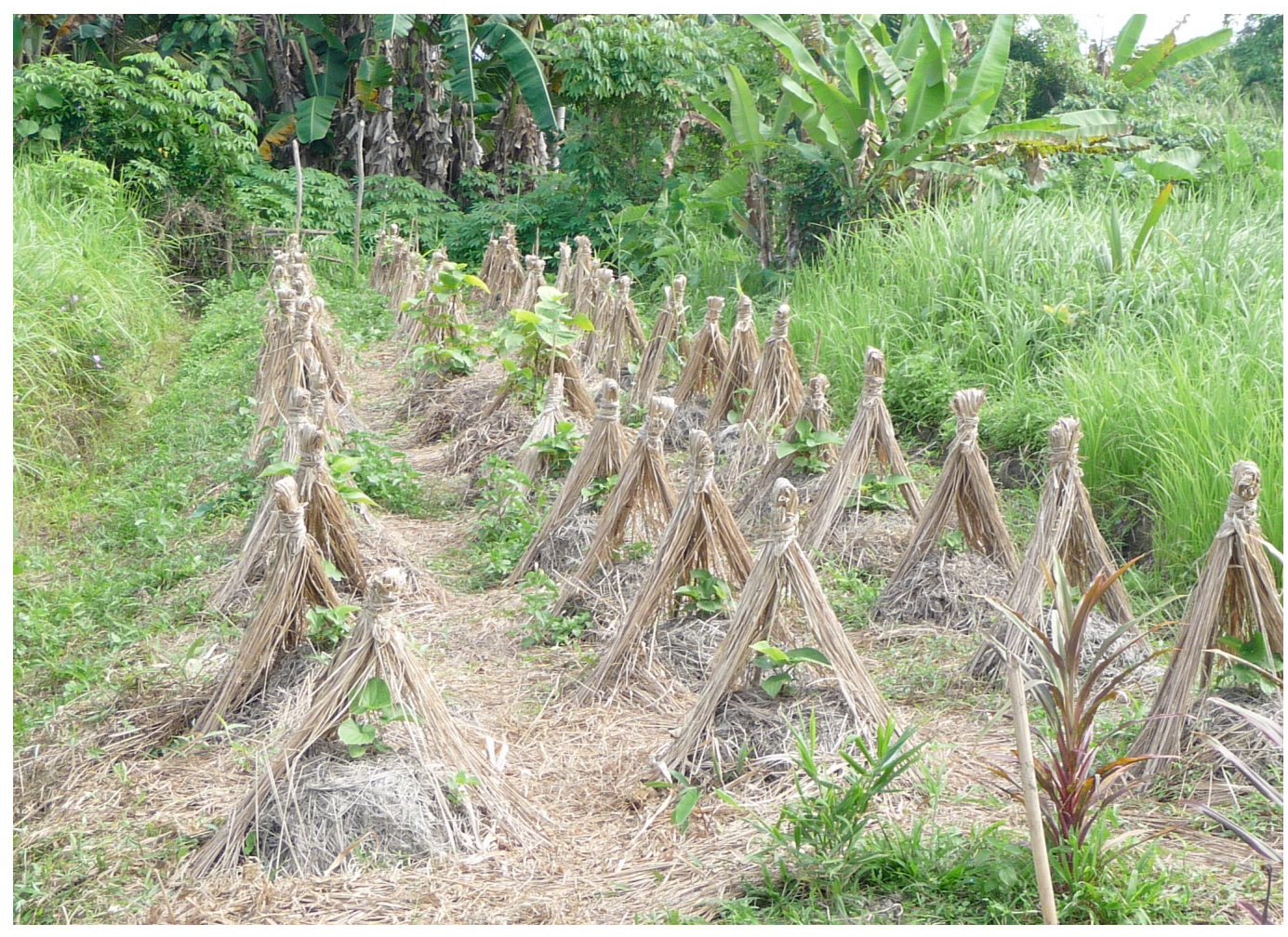

Figure 3-17. "Rumah anakan" is a sheltered lot of recent Wati plants made of Alang-alang grass (Imperata cylindrica) by people of Marind Swamp (Marind Rawa) (photo by KMB Kameubun). 


\section{3-1-5-3. Fertilization}

Wati plants require nutrition. The fertilizer used by Marind people is manure. The manure is received from rotten dry leaves of Alang-alang grass (Imperata cylindrica). The leaves are decomposed and then sprinkled on the "Wambada". Afterwards it is covered by a little amount of soil to keep it in place and covered by dry leaves of Alang-alang grass (Imperata cylindrica). This is carried out continually until Wati is ready for harvesting.

\section{3-1-5-4. Maintenance}

All three groups of the Marind tribes said that caring for the Wati plant is like caring for a baby. Caring for a baby is believed to be difficult. When not done carefully it may die. The same may happen with Wati. A lot of Wati plants (Wambada in Marind language) should be cleaned from grass and other plants that could disturb the growth and development of Wati plants, with the only exception of decorational plants as a custom.

Besides cleaning Wati plants need watering during the dry season. Watering depends on soil conditions. Good soil as medium is not too wet and not too dry. If the soil is too wet it affects the root and the main stem in the ground. They are bound to rot and eventually die off.

\section{3-1-5-5. Harvest}

Wati stems of the right age serve for seed or drink. Marind people usually take Wati of an age between 1 and 2 years from their garden. Usually, people recognize the, when the Wati plant has three main stems. When it grows more than 2 years, the stem can become hard. So it gets difficult to be chewed.

The harvest can be done by pulling out the plant and its roots (Figure 318). After the Wati plant is cleaned from soil, it is covered with a banana (Musa $\mathrm{x}$ paradisiaca) leaf, the bark of a Eucalyptus tree, or palm leaves (Arecaceae). So that it can't be damaged or fall to the ground on the way home (Figure 3-19). 
After it is wrapped up and tied it is brought home and used when needed (Figure $3-20)$.

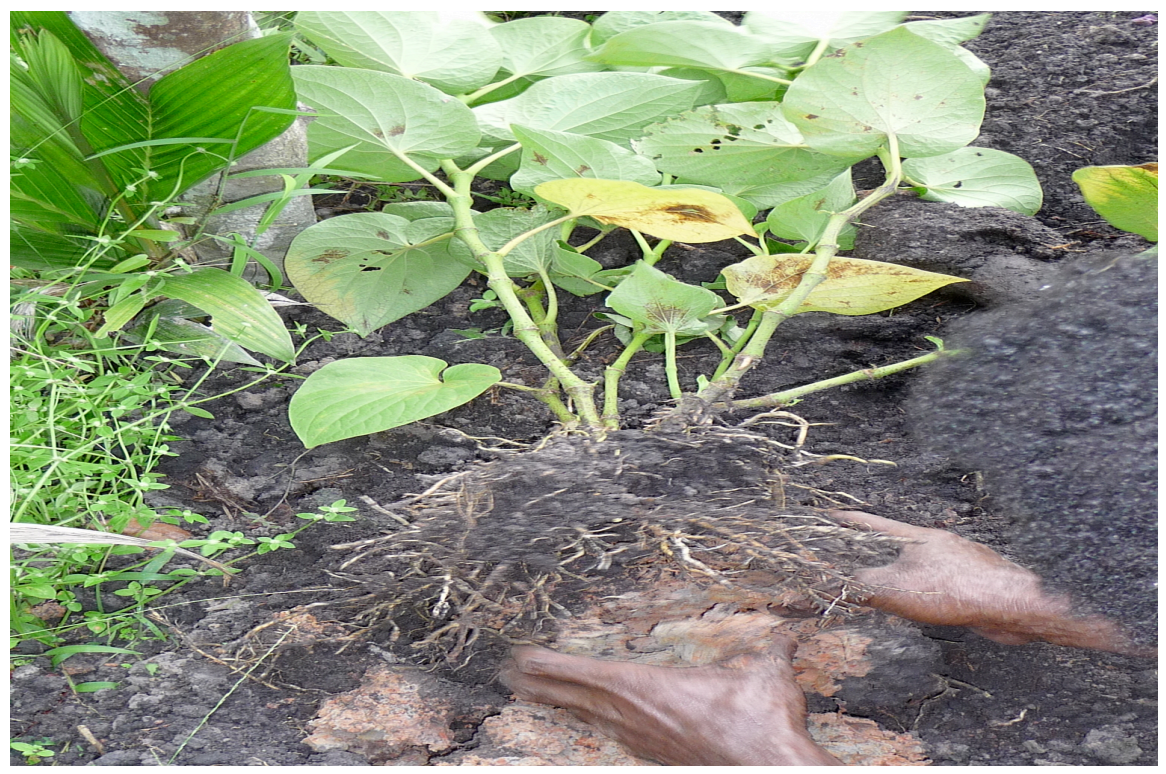

Figure 3-18. Harvesting of Wati plant (Photo by KMB Kameubun)

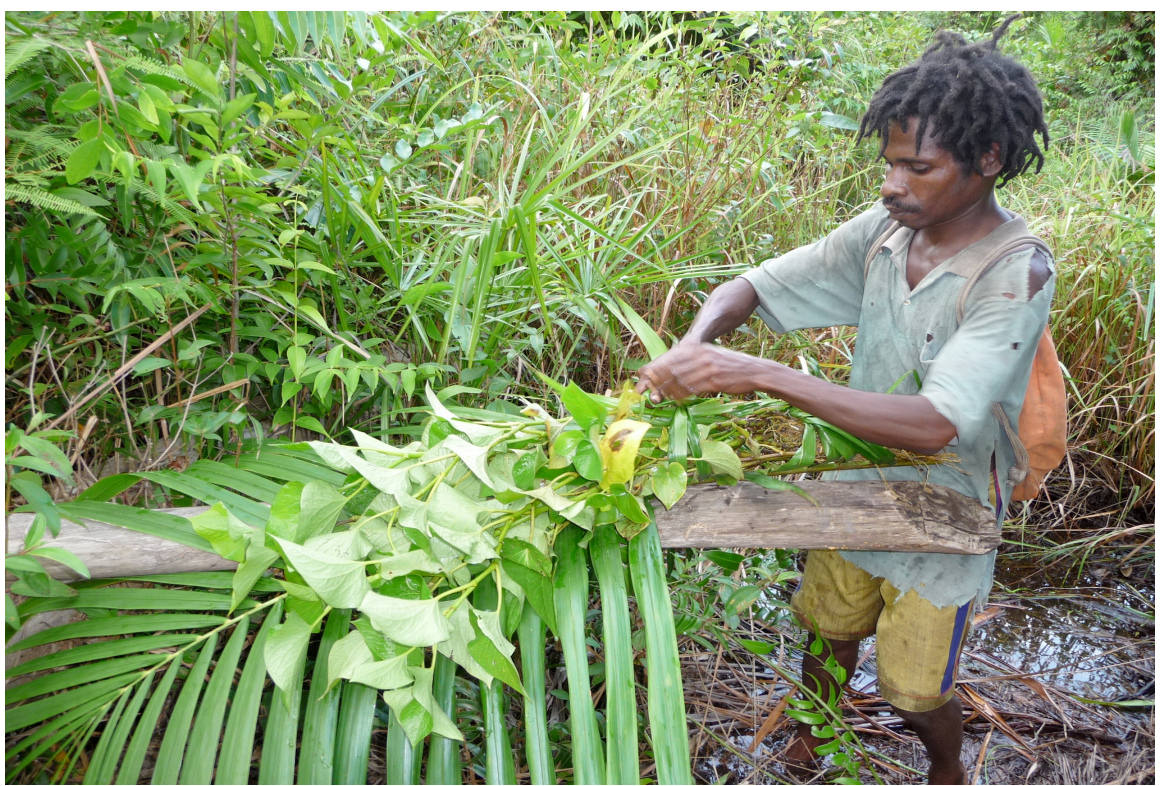

Figure 3-19. Wrapping up a Wati plant to be brought from the garden to the house (photo by KMB Kameubun) 


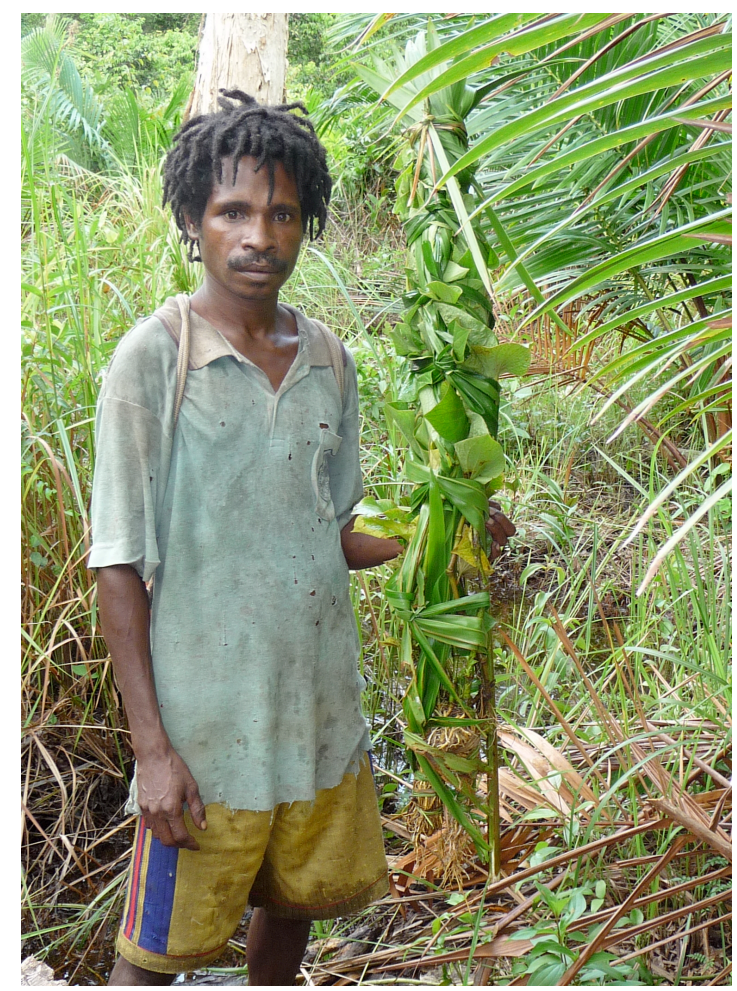

Figure 3-20. Wati plant wrapped up and ready to be brought home (photo by KMB Kameubun)

\section{3-1-6. The efforts in preserving Wati and the culture of Wati in Marind tribes}

In Merauke, it is common in villages with non-native citizens from other regions of Indonesia, such as Java, NTT, Sumatra, due to the governmental transmigration program. These Wati gardens can be found in villages with Marind tribe population. Each village may have 2 to 5 Wati gardens, the plot size being about $2 \times 8 \mathrm{~m}$ with ca. 64 individual Wati plants thereon. Wati plants use to grow well in gardens close to the forest.

In villages with non-native citizens Marind tribe people also plant Wati, but not so many, only 1 or 6 individual plants per plot. The size of the plot may be $1 \times 3 \mathrm{~m}$.

In central Merauke live heterogeneous people from various ethnic groups from Indonesia. They almost never have a Wati garden. But there are several people from Marind and non-Marind tribes living in Merauke that plant Wati in 
their house yards, in beds (Figure 3-21) and also in plastic bags (Figure 3-22), around 10 to 28 indivudual plants each.

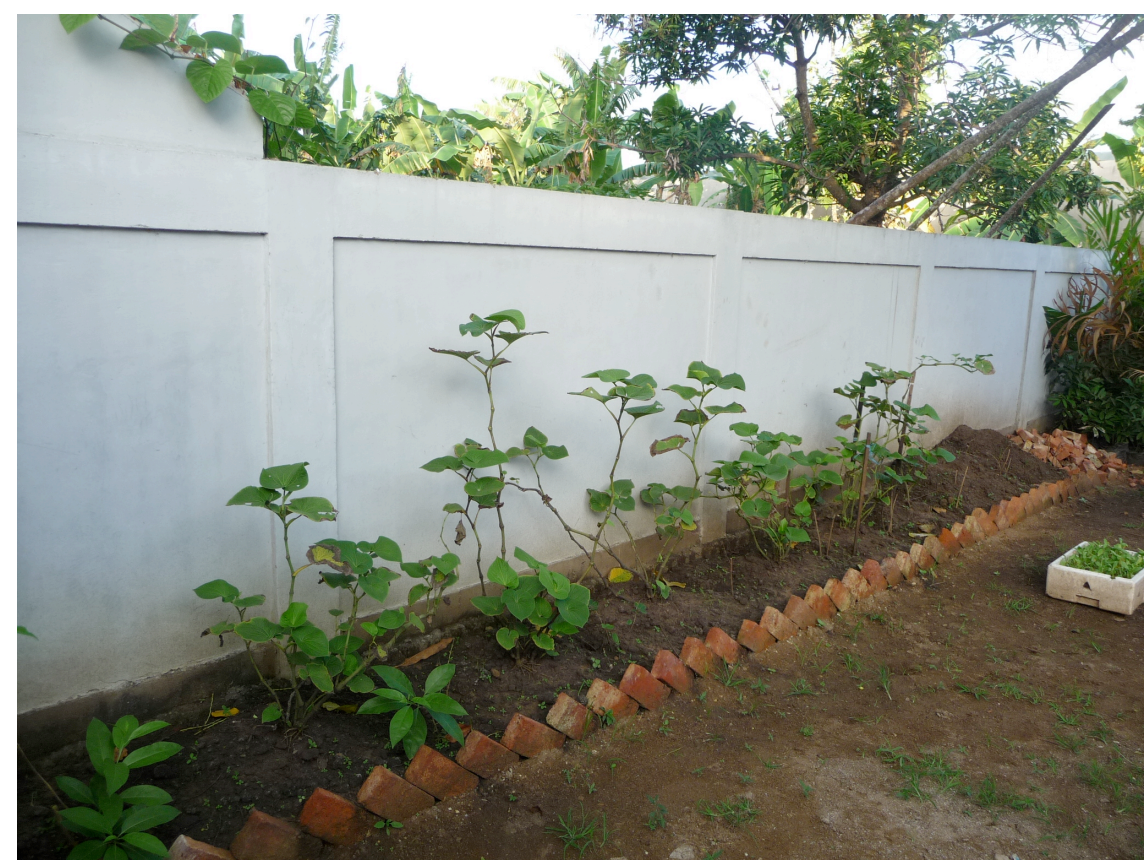

Figure 3-21. Planting Wati in their house yards in a bed by people in the central area of Merauke (photo by KMB Kameubun)

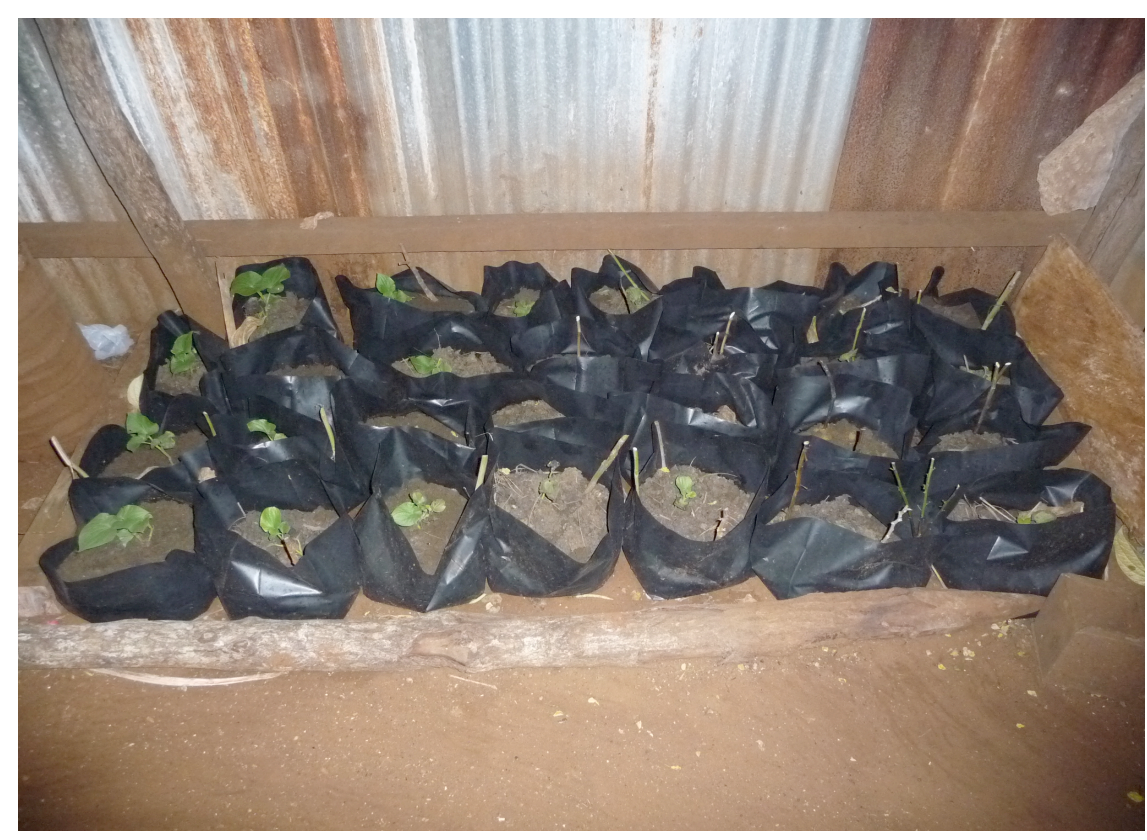

Figure 3-22. Planting Wati in their house yards, using plastic bags by people from the central Merauke area (photo by KMB Kameubun) 
In several villages, native people from Marind tribes didn't plant Wati because they are lacking seed or they don't have intention to have a Wati garden. The villages in the Waan district area of Marind Swamp (Marind Rawa/Marind bob) can't plant it because the soil condition is unfavourable for Wati growth. The reason is that the soil in these villages is contaminated by sea water. This results in a high salt content of the soil so that the survival of Wati plants becomes critical.

\section{3-1-7. The sales value of Wati plants}

Trading Wati is still limited in the area of Marind people. The price of Wati in Marind areas depends on the distance of the village or the town, from where the cultivar is taken and the size of the Wati cluster. Clusters are bought in remote villages. for example in Bamol and Yamuka. The minimum price is about 100.000 rupiah per small cluster (Figure 3-23) and 500.000 rupiah per big cluster (Figure 3-24). This price may rise depending on who sells the plant.

For example, in traditional markets in Wanam Marind people sell small bunches of Wati (Figure 3-25) for 20.000 rupiah per bunch, but the price is to increase in villages near town. The lowest price is 300.000 rupiah for a small cluster (Figure 3-23) and can reach a million rupiah for a big cluster (Figure 3-24). 


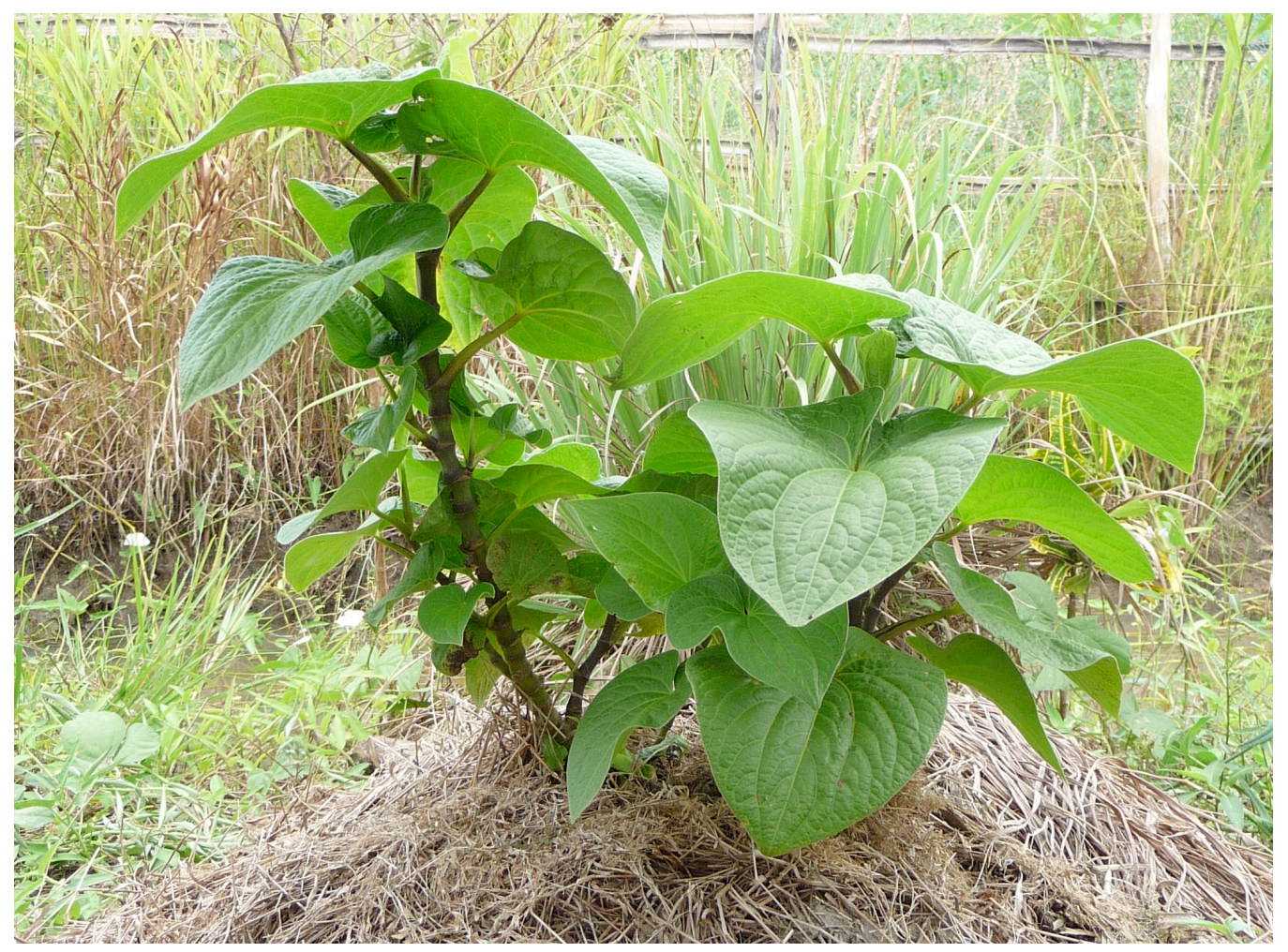

Figure 3-23. A small cluster of Wati plant (photo by KMB Kameubun)

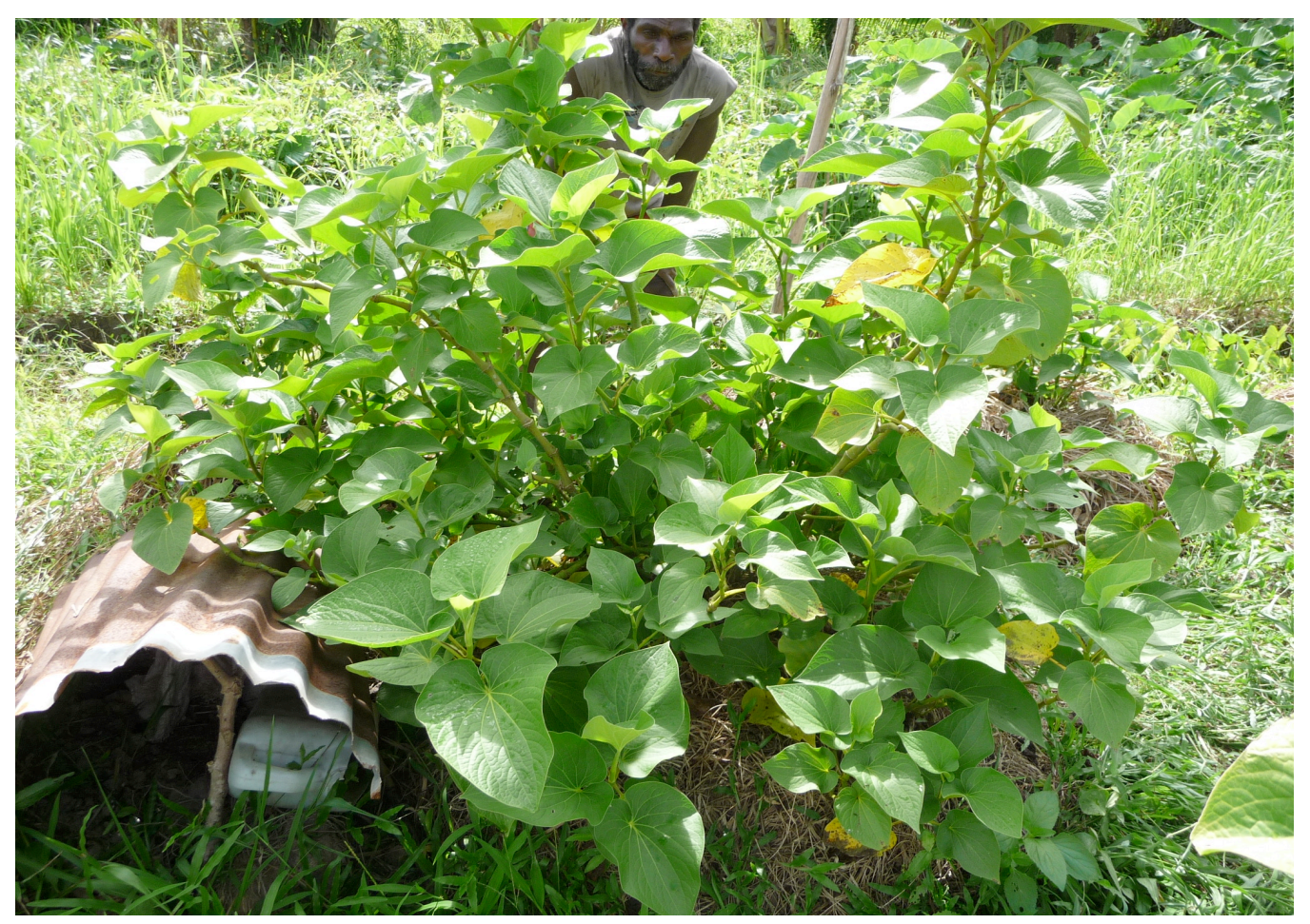

Figure 3-24. A big cluster of Wati plant (photo by KMB Kameubun) 


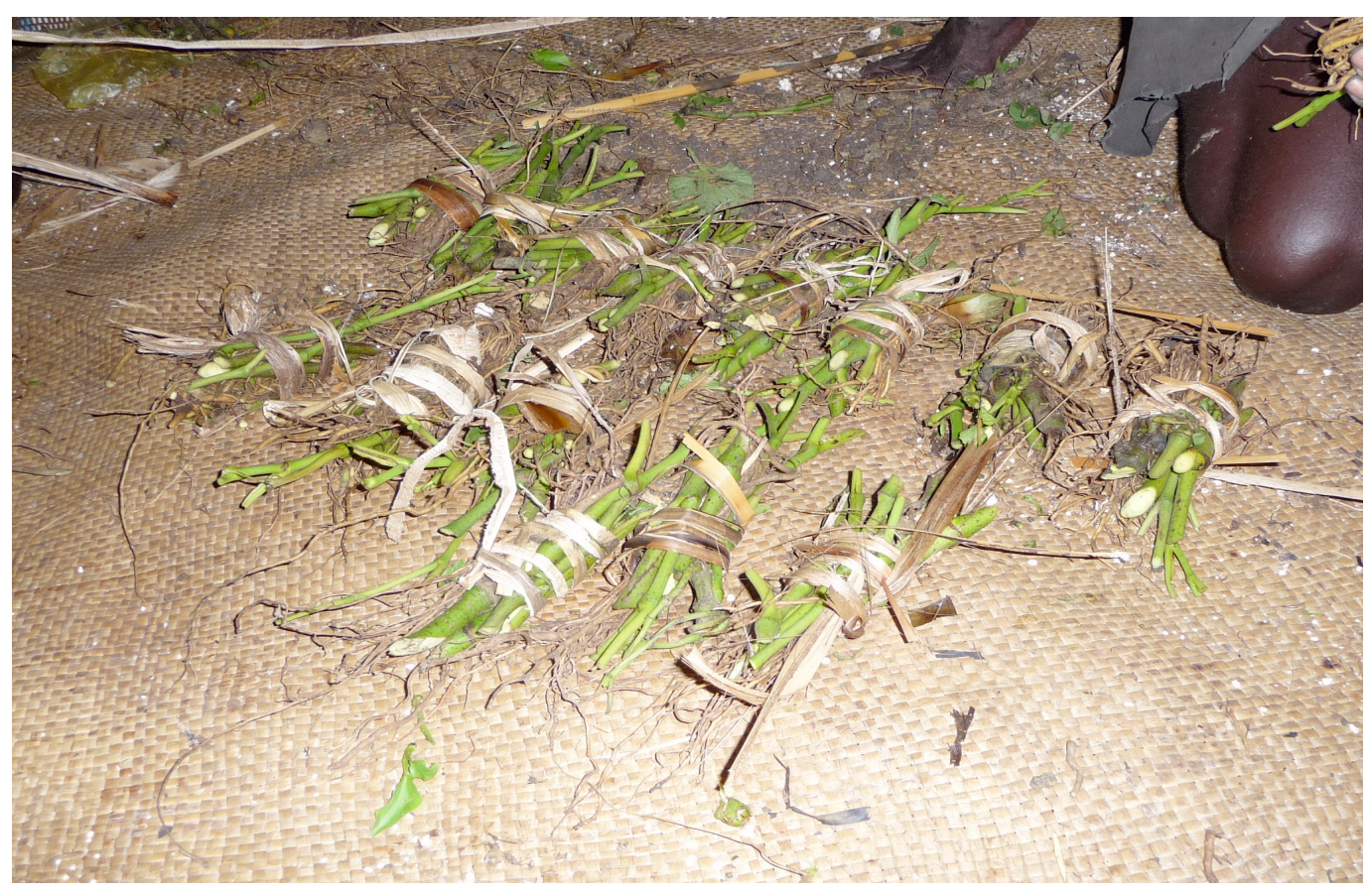

Figure 3-25. Bunches of cut stem and roots of Wati plants (photo by KMB Kameubun) 


\section{3-2. DIVERSITY STUDY OF THE WATI PLANT (Piper methysticum Forst.) FROM MERAUKE BASED ON MORPHOLOGICAL CHARACTERISTICS}

\section{3-2-1. Morphological diversity of the Wati plant}

Based on morphological characteristics of the Wati plant in Merauke area, two species are identified: Piper wichimannii and Piper methysticum. Piper methysticum has 5 varieties. In other biological terms a cultivated plant is called a cultivar. Piper methysticum has the following cultivars: Safurawe, Munana, Palima, Kuning, and Babid.The cultivar names of Piper methysticum correspond to the local names. The cultivar Marub in Kameubun (2003) is the species Piper wichimannii.

\section{3-2-1-1. Habitus}

The Wati plant appears in two habitus forms, as a small tree and as a shrub. The shrub habitus reaches a height of 1 to $2 \mathrm{~m}$ in several cultivars of $P$. methysticum species. The height of small tree habitus is up to $4 \mathrm{~m}$ for $\mathrm{P}$. wichimannii. According to popular knowledge it may reach up to $5 \mathrm{~m}$.

\section{3-2-1-2. Root}

The root of $P$. methysticum and P. wichimannii are tap roots. The size of a tap root ranges from $0.01 \mathrm{~cm}$ to $0.8 \mathrm{~cm}$ in diameter. It is of brownish color. This tap root has a lot of mais roots and fibers roots grow out from the node stem (Figure 3-26).

The structure, cell form and tissue anatomy of the cross-section of the root from Piper wichimannii and Piper methysticum in the Merauke area are identical (Kameubun, 2003). The cross-section of the root comprises an epidermis cell layer at the outside. The function of this epidermis layer is to protect the enclosed tissue. The ensuing cortex layer is not evenly structured. The next layer is the endodermis. The endodermis surrounds the vascular tissue layer. There are phloem and xylem parts in the vascular tissue. The phloem and xylem parts are 
radially composed around the deepest layer that is called pith. Cambium parts can be found after the cortex layer. The cambium layer looks like a spotted line surrounding the phloem and xylem parts that build circle in a sectional view.

Lateral roots sprout from a cylindrical layer consisting of several primordium cells. The primordium stretches out across the cortex and eventually reaches the surface. Lateral roots are root parts of the main roots. Each of them can be branched again (Figure 3-27).

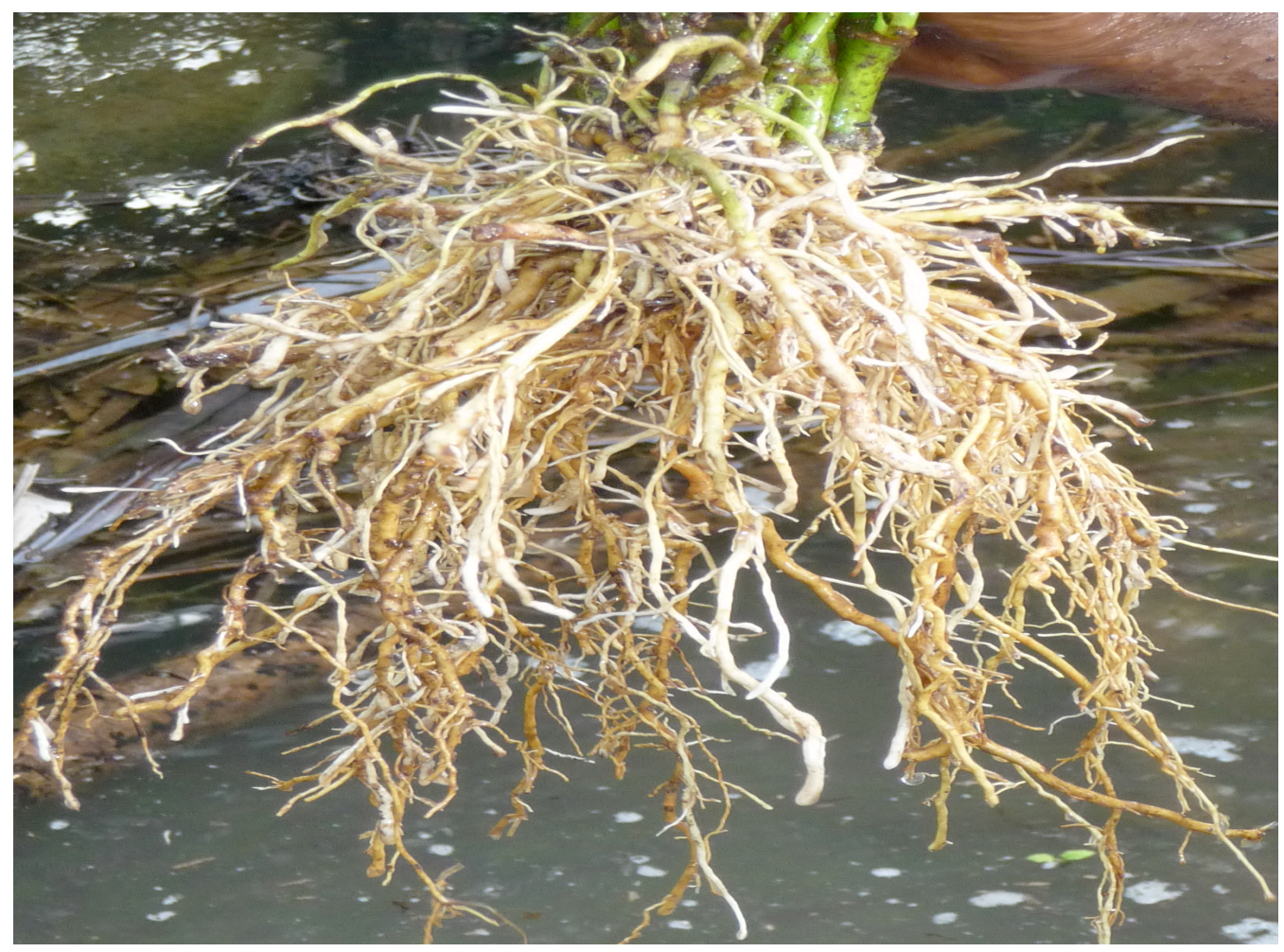

Figure 3-26. Wati roots from the shrub habitus (Photo by KMB Kameubun). 

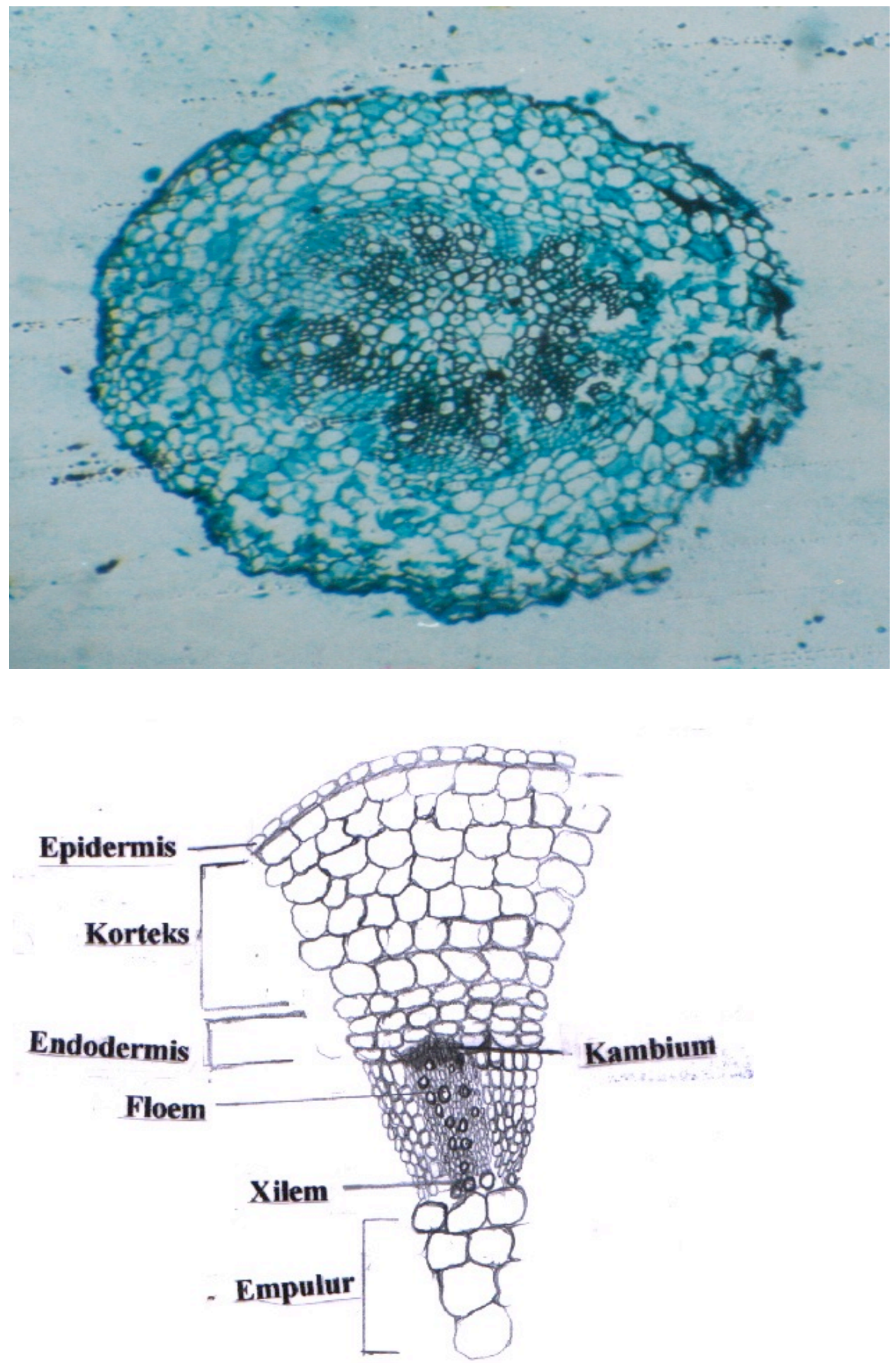

Figure 3-27. Cross-section of Wati roots from the shrub habitus, $(40 \times 2$, 5) (Photo and drawing by KMB Kameubun, 2003). 


\section{3-2-1-3. Stem}

The stem of Wati plant has an oval shape, is wooden and has cambium on the bark of the stem, internodes and nodes. Here the leaves and the flowers are attached to the stem node. Branching occurs shortly before the age of one year. The stem color is different among the cultivars, it may change between green, greenish red and brownish red (Figures 3-28 and 3-29). Some varieties have small green spots on the stem while others do not (Figure 3-30). These spots are lenticels.
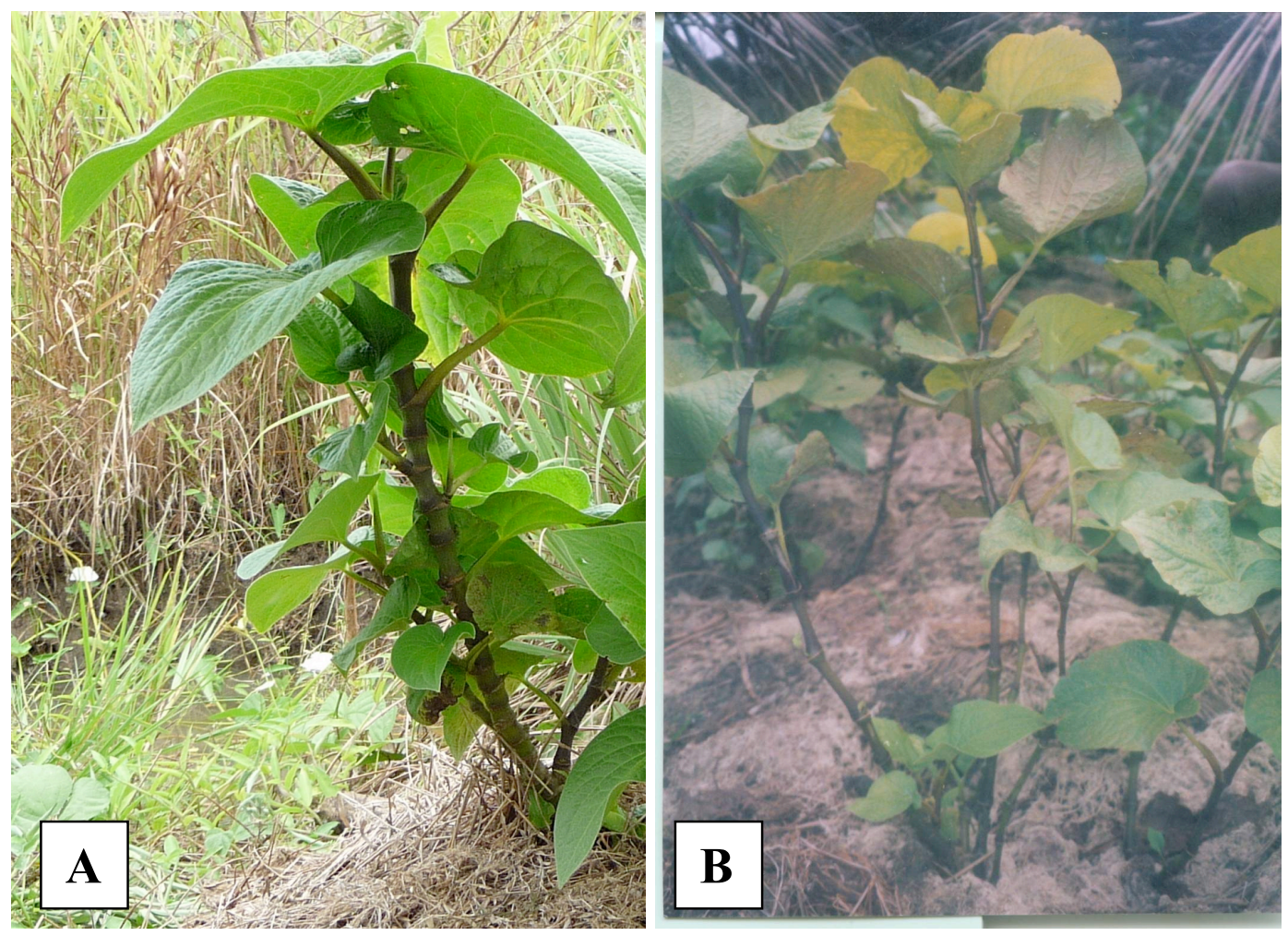

Figure 3-28. Categorization of stem color: black, brown, and red in short stem internodes (A) and long internodes (B) (Photo by KMB Kameubun). 

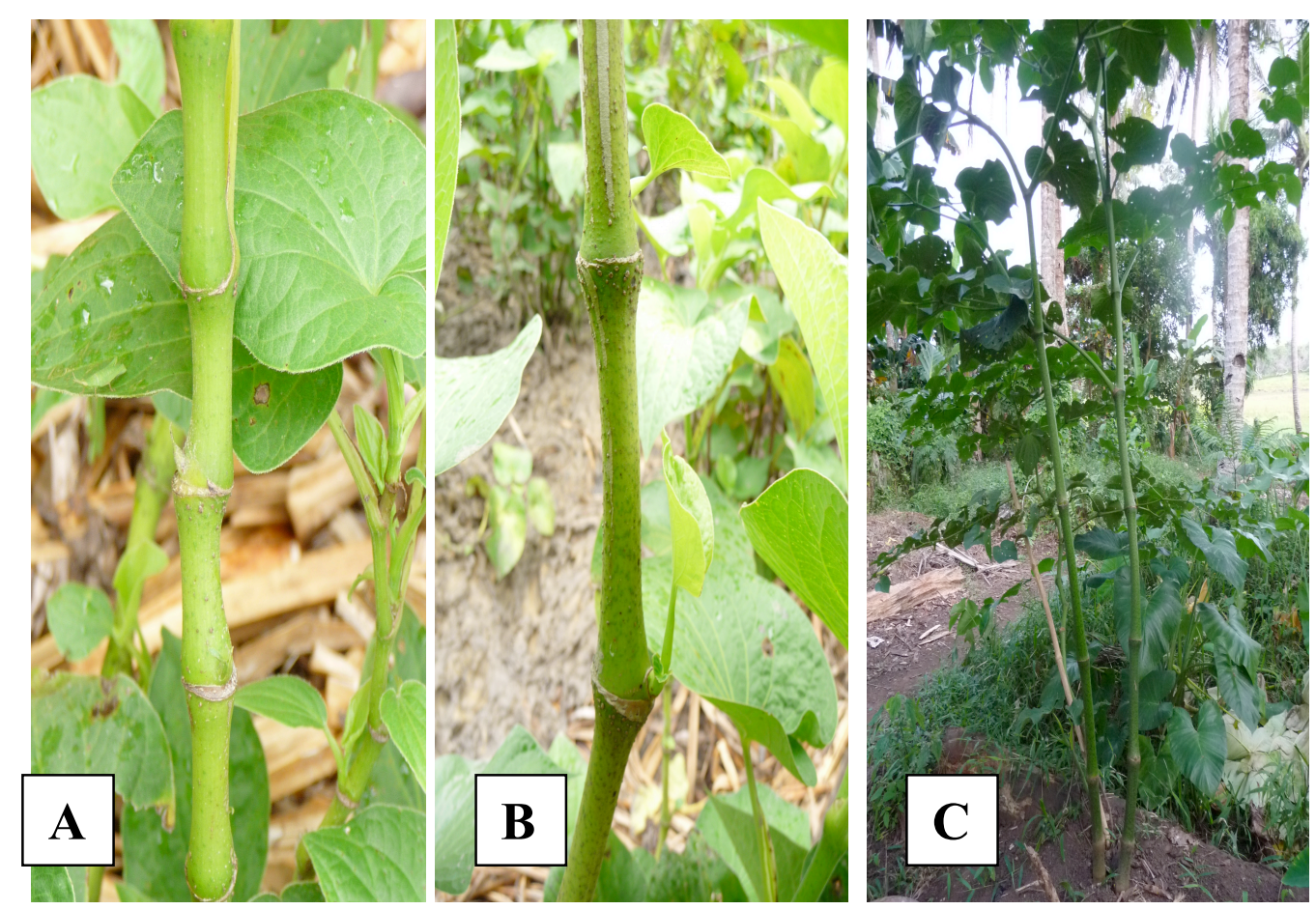

Figure 3-29. Categorization of color of green stem for long internodes: (A) short; (B) long; (C) very long (Photo by KMB Kameubun).
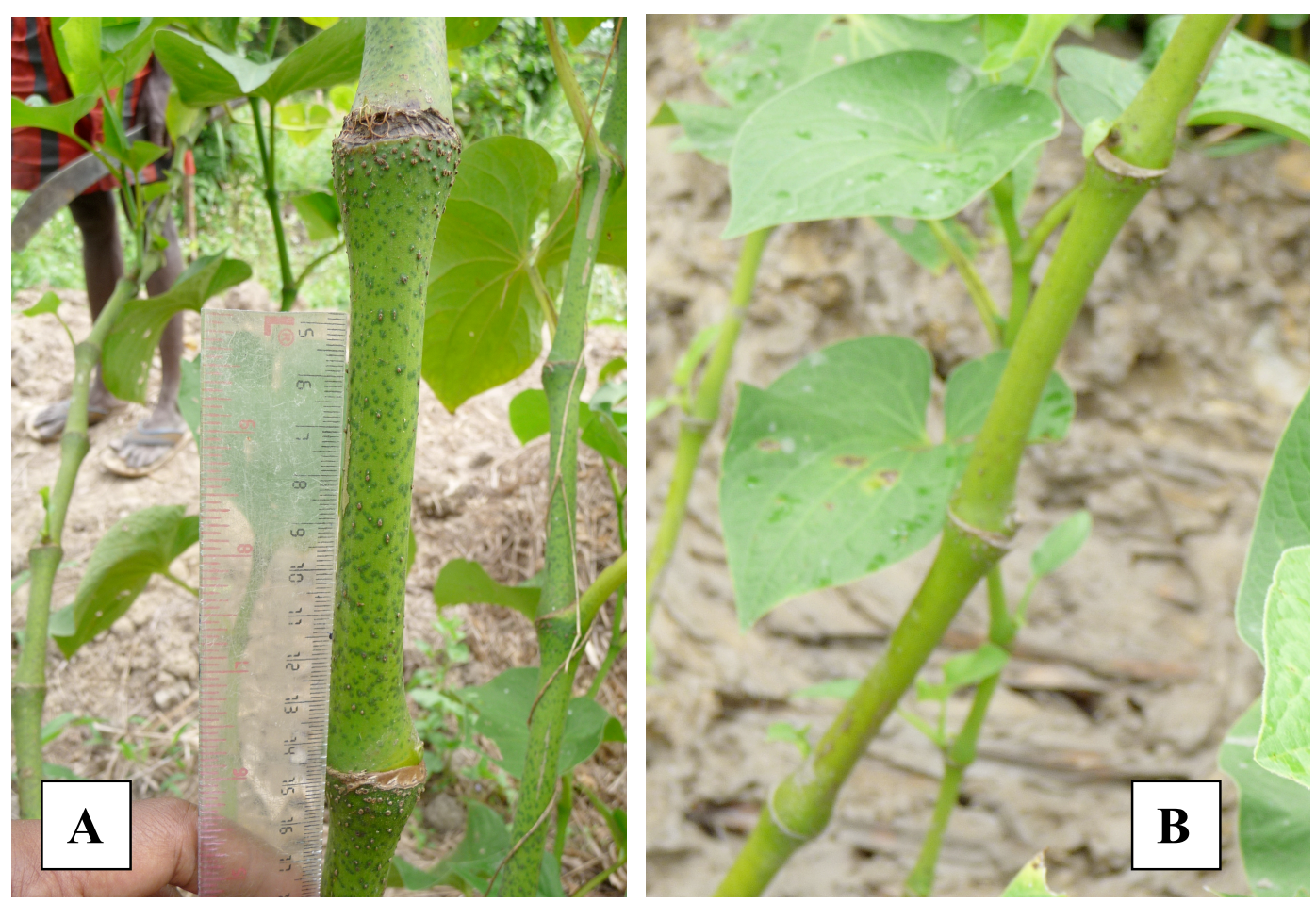

Figure 3-30. Stem categorization. (A) densely spotted; (B) any or only few spots (Photo by KMB Kameubun). 
The structure, cell form and tissue anatomy of stem cross-sections from Piper wichimannii and Piper methysticum in the Merauke area identical (Kameubun, 2003) (Figure 3-31). It is arranged in a single layer epidermis. The hypodermis is a single layer in the epidermis. The cortex layer is in the hypodermis which consists of several layers.

Cambium borders the vascular tissue. The vascular tissue runs circular around the main stem, the pith. The xylem is inside and the phloem is on the outside of this circular section of the vascular tissue. In the stem there is cell oil. The cell oil displays a yellow color. It is present in all cell layers. Cell oil can be clearly visualized in a preparation by freeze method, as shown in Figure 3-32. 

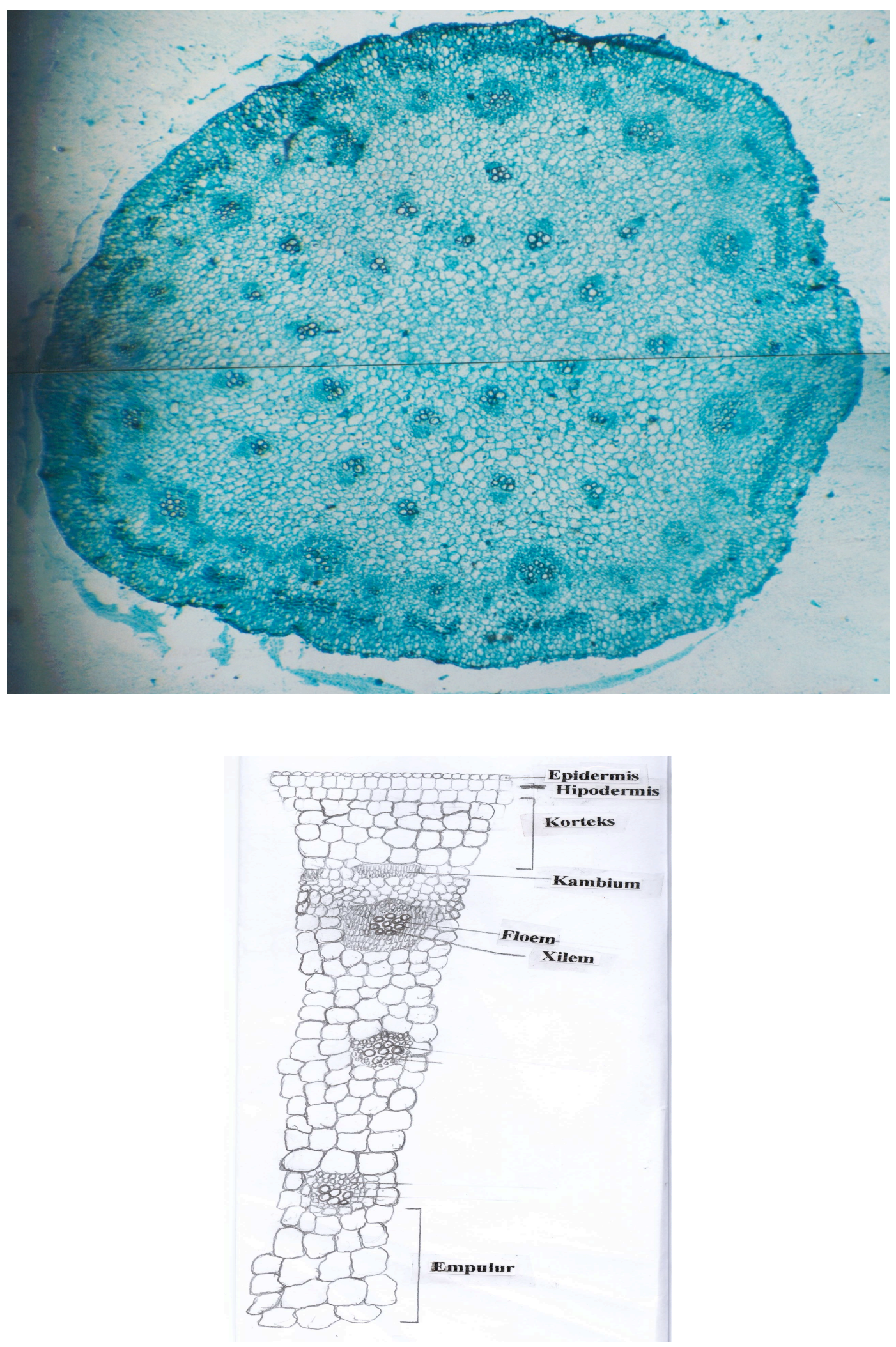

Figure 3-31. Cross-section of a Wati plant of the shrub habitus, (40 x 4) (Photo and drawing by KMB Kameubun, 2003). 


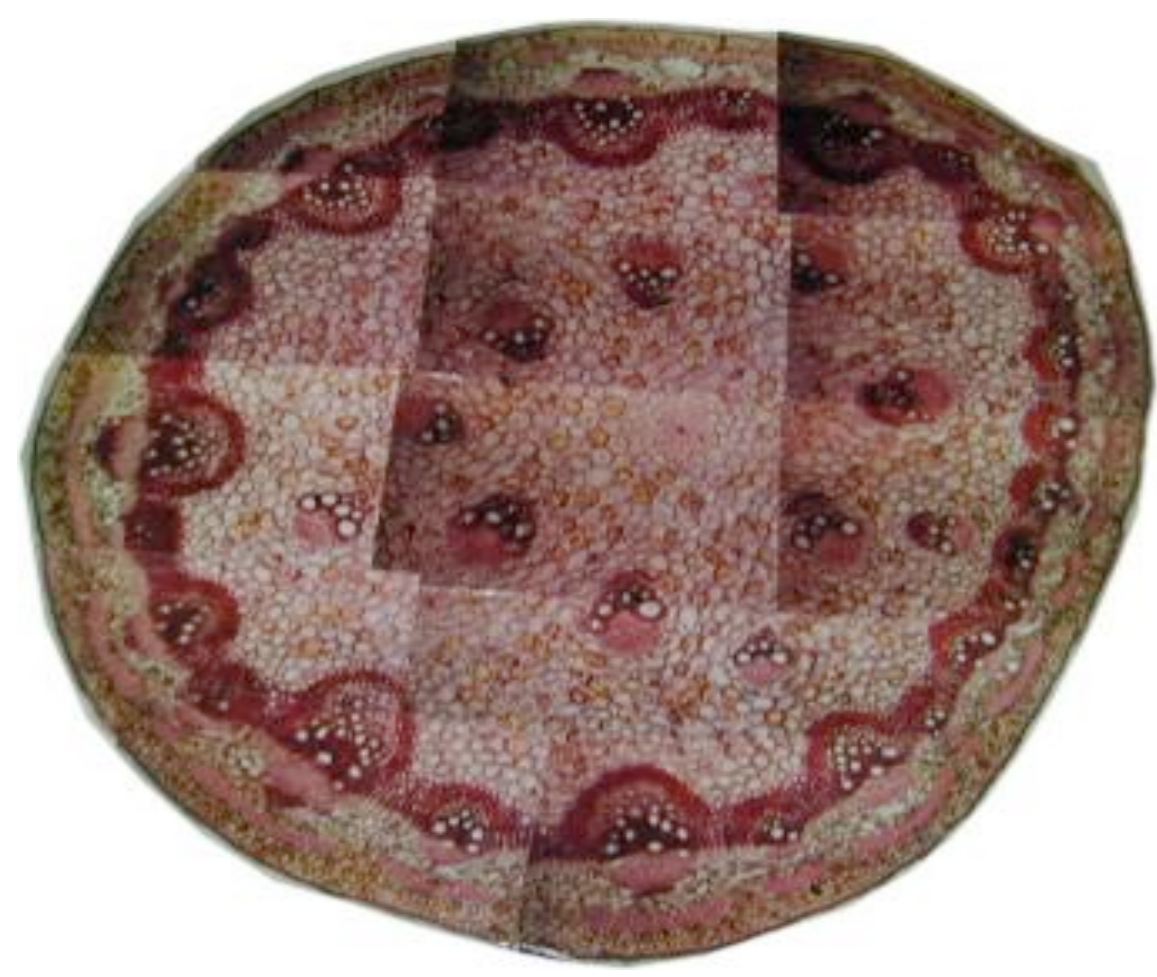

Figure 3-32. Cross-section of a Wati stem of the shrub habitus with a green stem yielded by freeze method. Yellow cell oil can be seen (photo by Sumarni, Treub LIPI lab, Bogor).

\section{3-2-1-4. Leaves}

In a leaf sheet leaves are sprayed. There is only one leaf per stem node. They are alternatingly arranged, are heart-shaped and have a length of $14.5-19$ $\mathrm{cm}$ and a width of $11-16 \mathrm{~cm}$. Such leaves are categorized as broad leaves. In a sheath leaf, the leaves surrounded the stem node. They reach $3 \mathrm{~cm}$ in length, the width is $1-2,5 \mathrm{~cm}$. The leaf stalk with a length of $1-2 \mathrm{~cm}$ is located proximal to the sheath leaf. There are yellowish-red stipula with black spots (Figure 3-33) and greenish-red stipula without spots (Figure 3-34). The stipula are found on the stem node, beside the site of the leaf. The leaf color is green, dark green and goldishyellow green (Figure 3-35). There are slippery, soft, dimpled leaves. The leaves have main veins which are curve-shaped. The tip of the leaf is tapered. A ringshaped mark is left when the leaf falls off. 


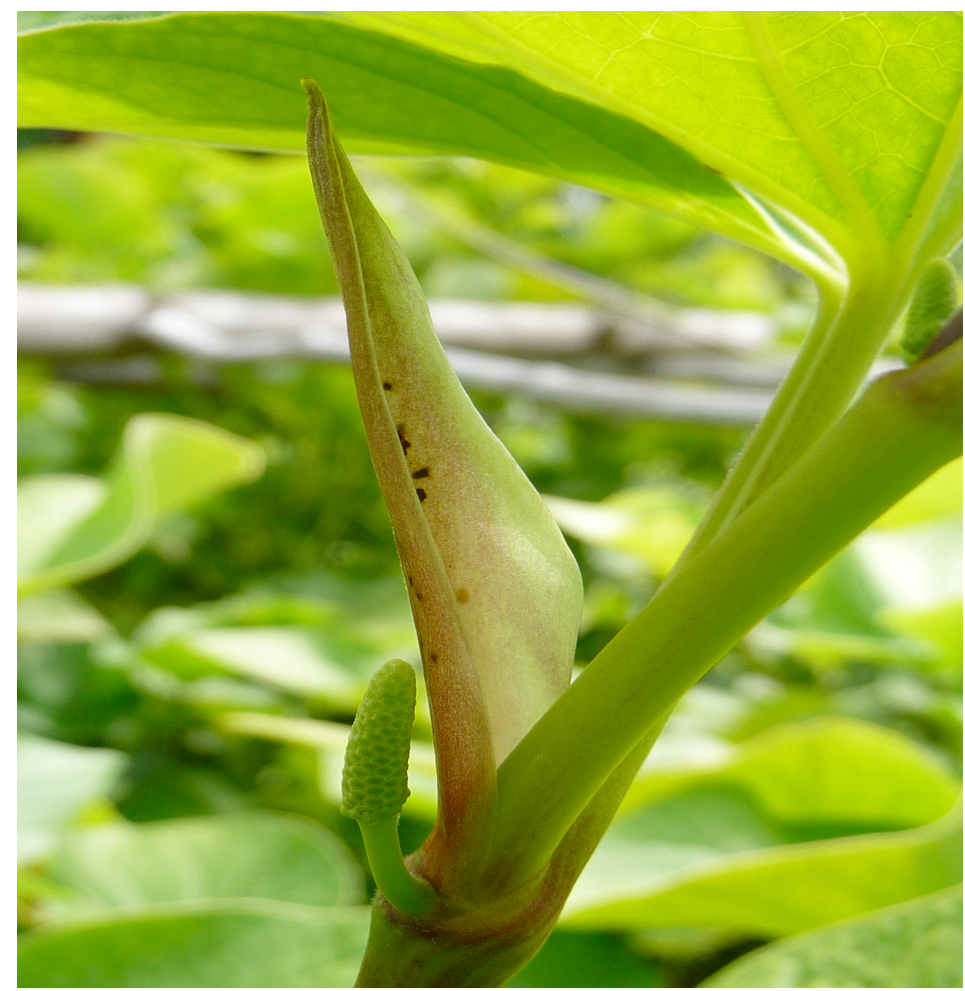

Figure 3-33. Stipula from the shrub habitus, Piper methysticum cultivar Palima (Photo by KMB Kameubun).

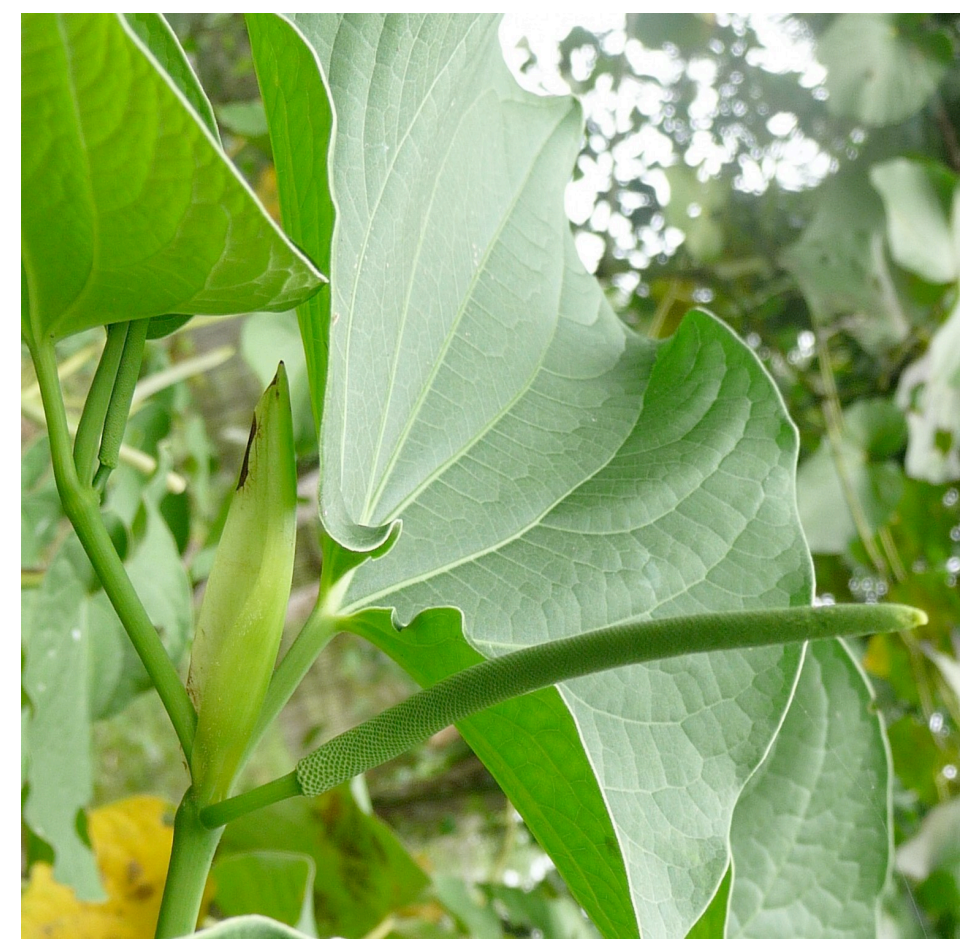

Figure 3-34. Stipula from the small tree habitus, Piper wichimannii (Photo by KMB Kameubun). 

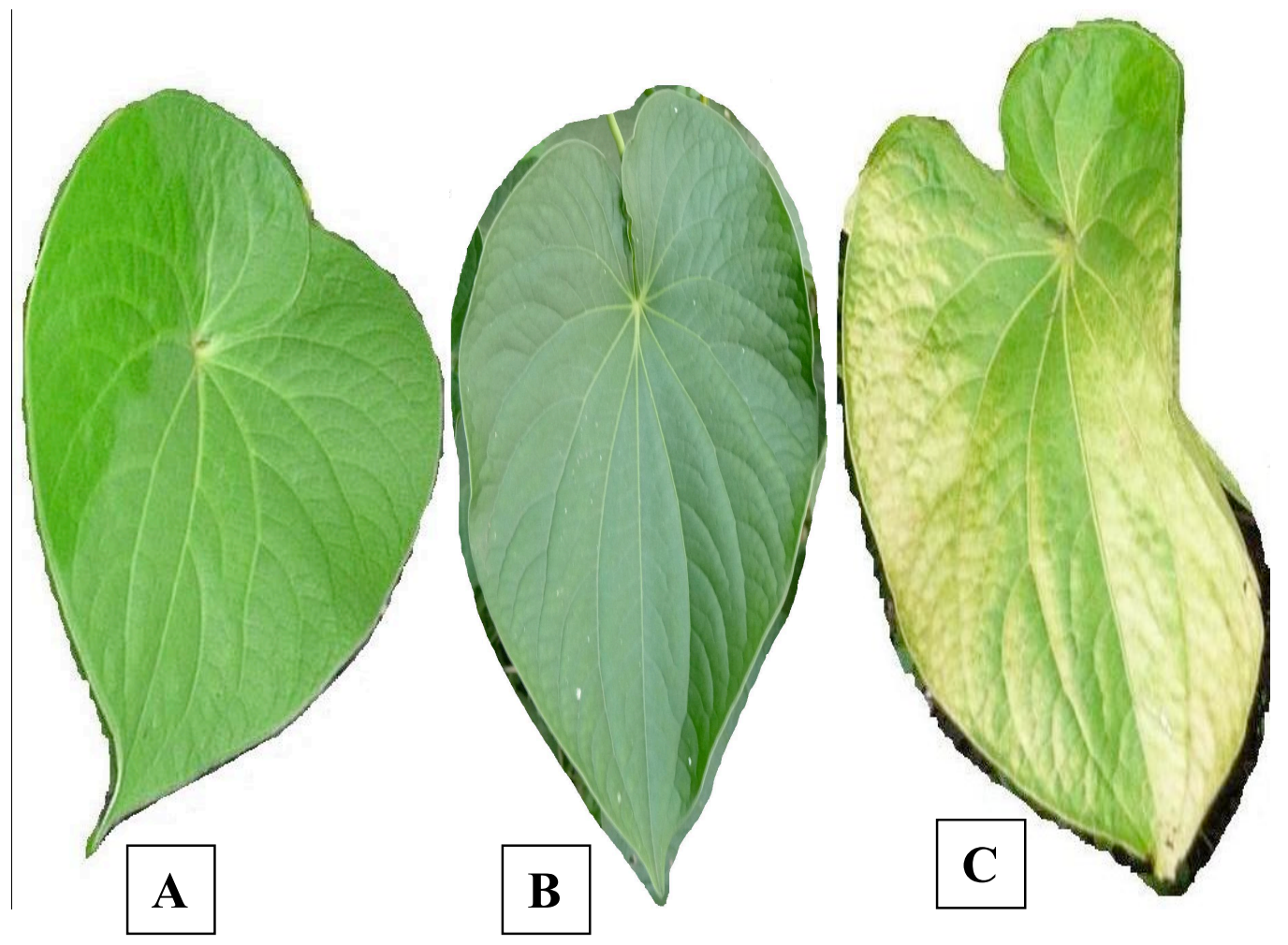

Figure 3-35. Diversity of the leaf color in the Wati plant in Merauke (A). green (B). dark green (C). goldish-yellow green.

The structure, cell form, and tissue anatomy of leaf cross-sections from Piper wichimannii and Piper methysticum in the Merauke area are identical (Kameubun, 2003) (Figure 3-36). The leaf cross-section show a system of three tissue types: Top and bottom epidermis, mesophilic and vascular tissue. The epidermis consists of 2 layers, top and bottom epidermis. Cell forms are square and rectangle. The next layer is the mesophil. The mesophilic layer consists of 2 parenchyma are palisade parenchyma and coral parenchyma (or spoon parenchyma). In the palisade parenchyma and coral parenchyma (or spoon parenchyma) chlorophyll-containing chloroplasts are found.

There is cell oil in the leaves. The cell oil can be visualized in crosssections. It is of yellow colour and can be found in all cell layers. The cell oil can not be seen clearly in paraffin-staining preparations. The cell oil can be 
recognized clearly in sections of the shrub habitus with a green stem prepared by the frozen method (Figure 3-37)

There are trichoma in the epidermis (Figure 3-38). These are epidermis protrusions. The trichoma structure can be categorized on the bais of its morphological characteristics as hair trichoma. Trichoma size differs among the habitus of the Wati plant. The trichoma of the small tree habitus reached up to 17, $16 \mu \mathrm{m}$, in the scrub habitus they reached up to $14.04-21.16 \mu \mathrm{m}$, and up to 21.32 $\mu \mathrm{m}$. As comparison, the shape of trichoma from a Piper species (Piper gibilimbum ) is shown that differ in their morphological characteristics and are almost similar to Piper methysticum (Figure 3 - 39). 

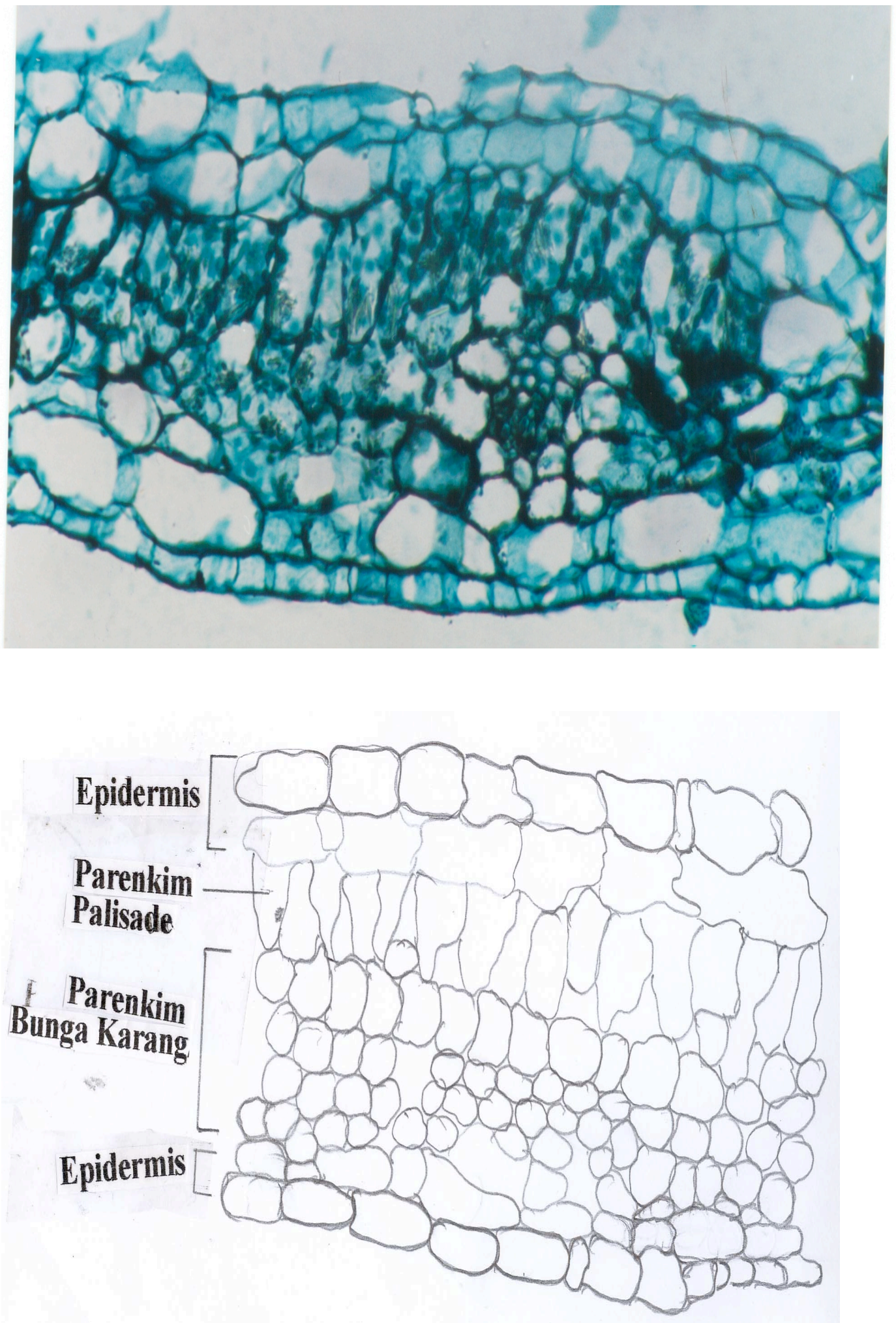

Figure 3-36. Cross-section of a Wati plant leaf of the shrub habitus (red stem and long internode $(40 \times 2.5)$ using the paraffin method (Photo and drawing by KMB Kameubun, 2003). 


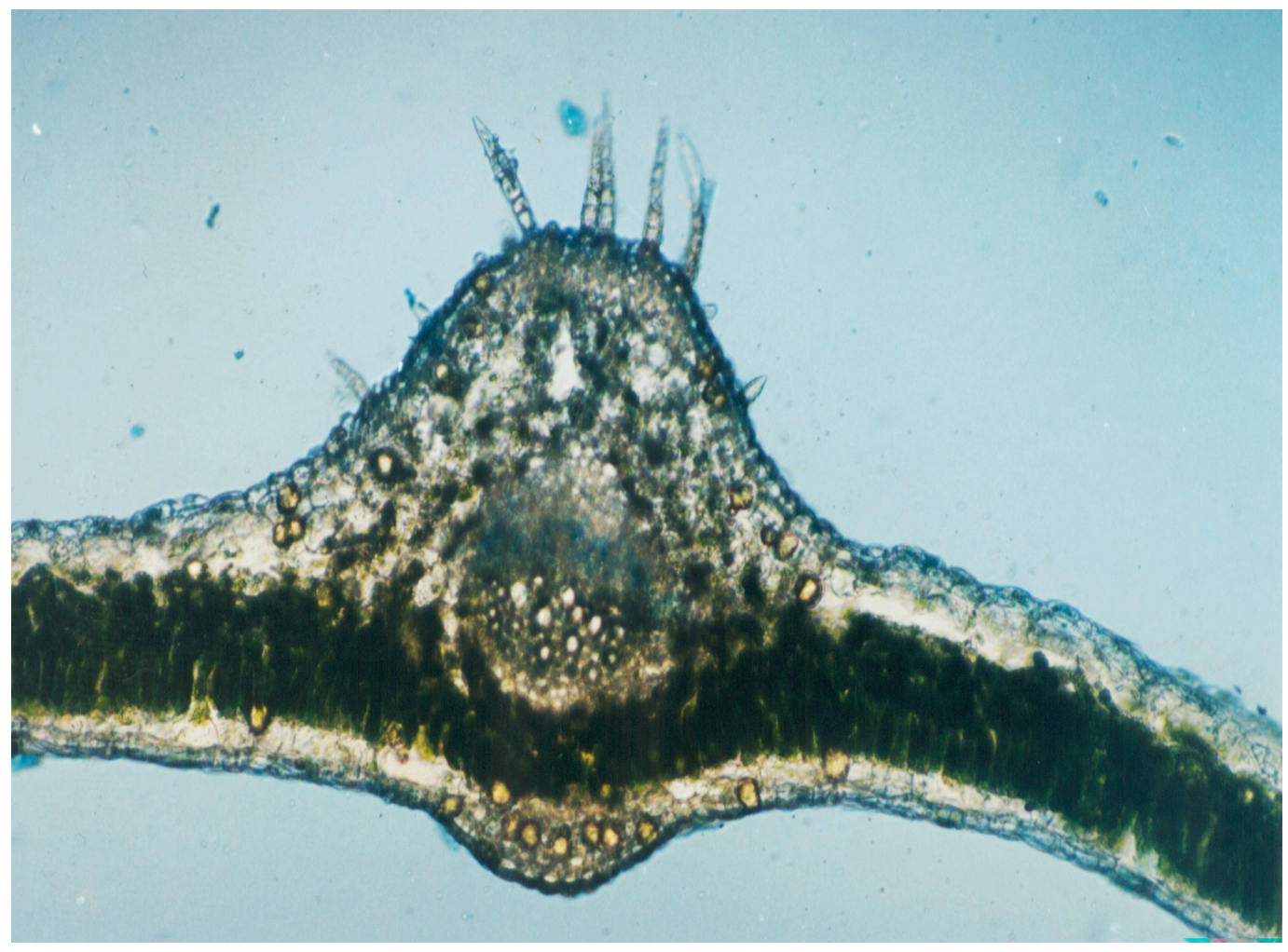

Figure 3-37. Trichoma in a cross-section of a Wati leaf of the shrub habitus with a green stem by using the freeze method (Photo by Sumarni, Laboratorium of Treub LIPI- Bogor).

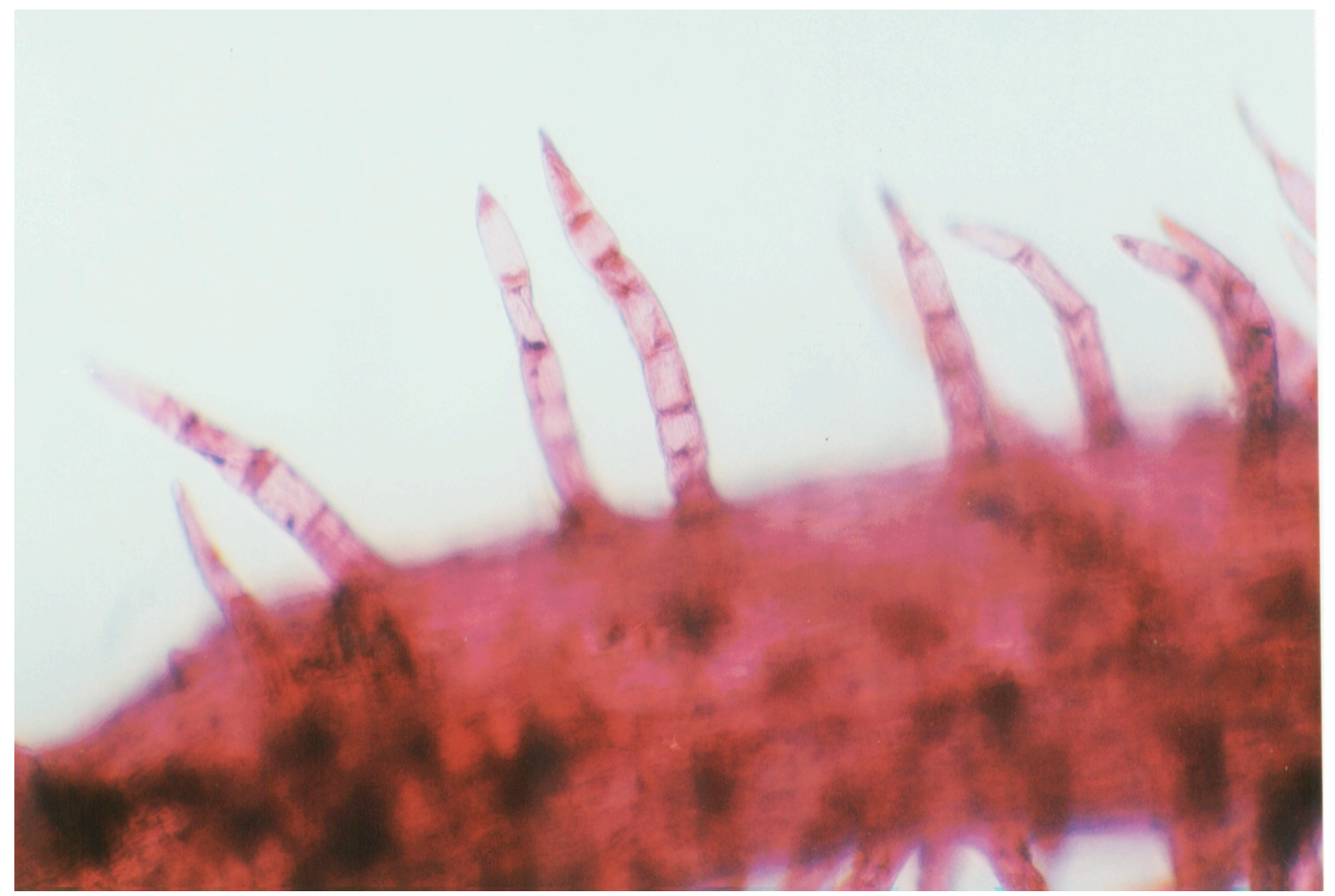

Figure 3-38. Trichoma in a slice from the leaf veins of a Wati plant of the shrub habitus $(20 x 2,5)$ using the paraffin method (Photo by KMB Kameubun, 2003) 


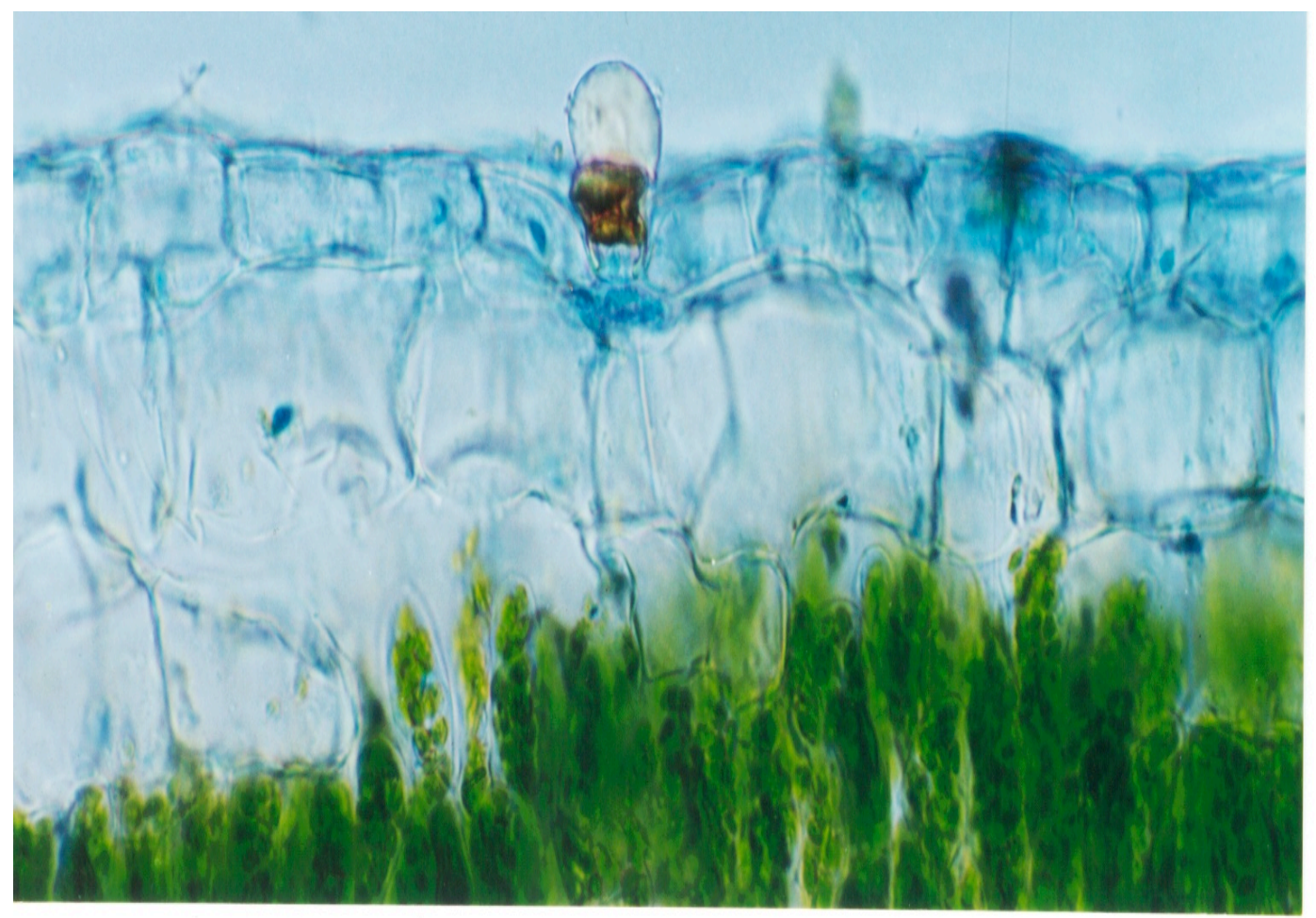

Figure 3-39. Trichoma in a cross-section of a Piper gibilimbum leaf of the shrub habitus with a green stem by using the freeze method (Photo by Sumarni, Laboratorium of Treub LIPI- Bogor).

Stomata with a paradermal incision of the upper surface of a Wati plant leaf are wide-spread. The cover cell of the stomata shows a kidney form, it is positioned higher than the epidermis (Figure 3 - 40). These stomata can be assigned to the anomositic type. In the anomositic type a number of neighbor cells surround the cover cell. Their categorization is ambiguous and cannot be differentiated from epidermis cells or stomata without neighbor cells (Sumardi and Agus P, 1993; Suradinata, 1998). 

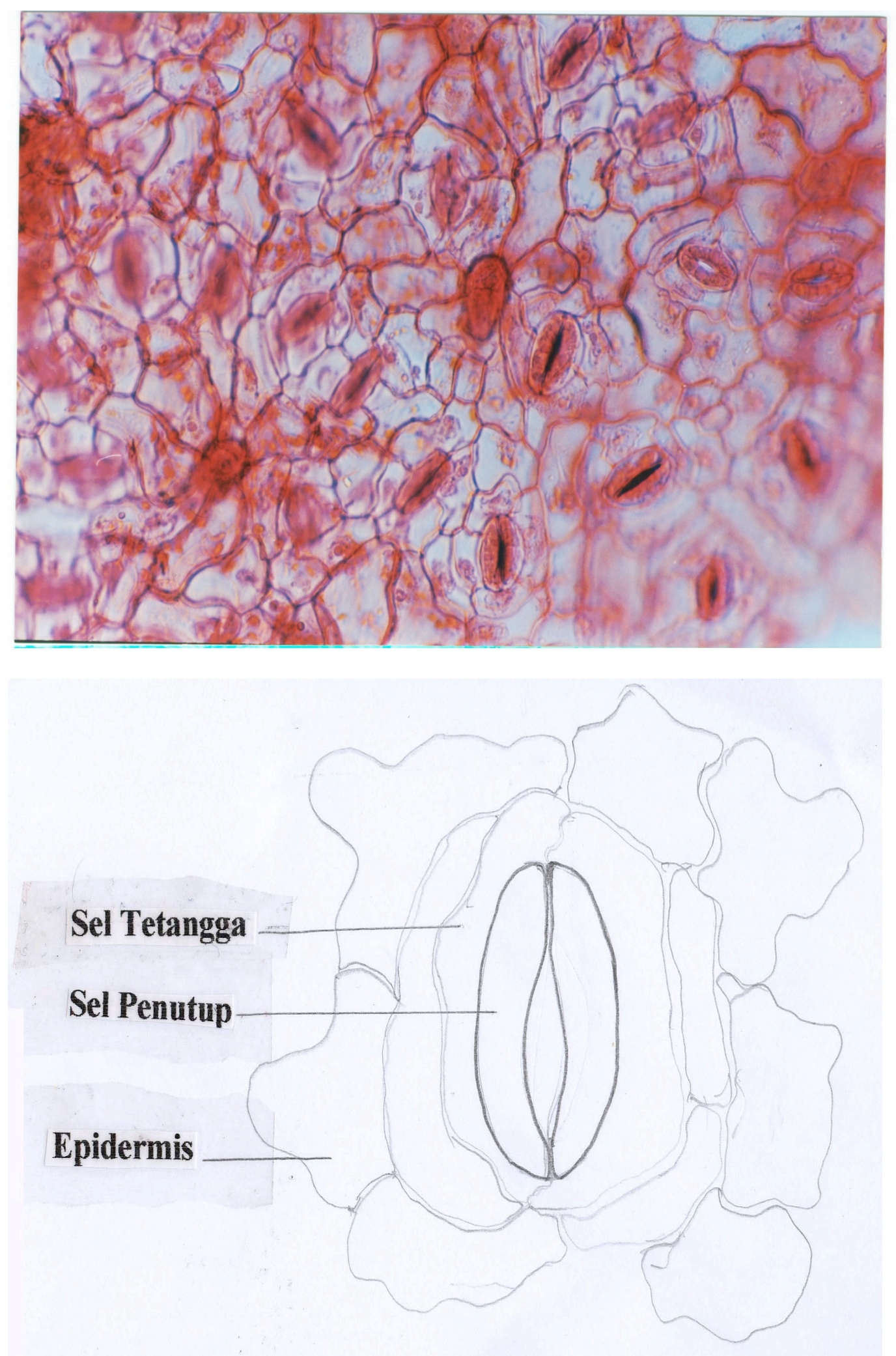

Figure 3-40. Stomata in a paradermal incision of the upper surface of a Wati plant leaf $(40 \times 2.5)$ using the paraffin method (Photo and drawing by KMB Kameubun, 2003). 


\section{3-2-1-5. Inflorence}

Flowers of the Wati plant can be usually found when the Wati plant is more than 1.5 years old. A flower of a Wati plant will sprout out from node of the stem, opposite to a leaf (Figure 3-41 and 3-42).

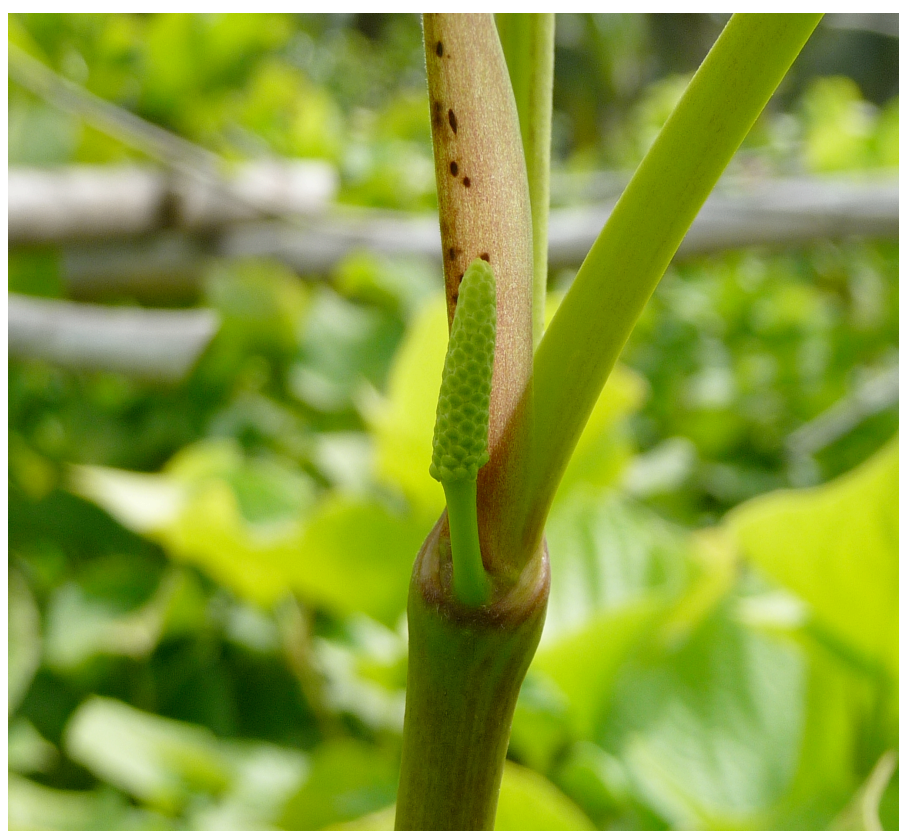

Figure 3-41. Inflorescence on a shrub habitus, brownish red stem, long internode, Piper methysticum cultivar Palima (Photo by KMB Kameubun)

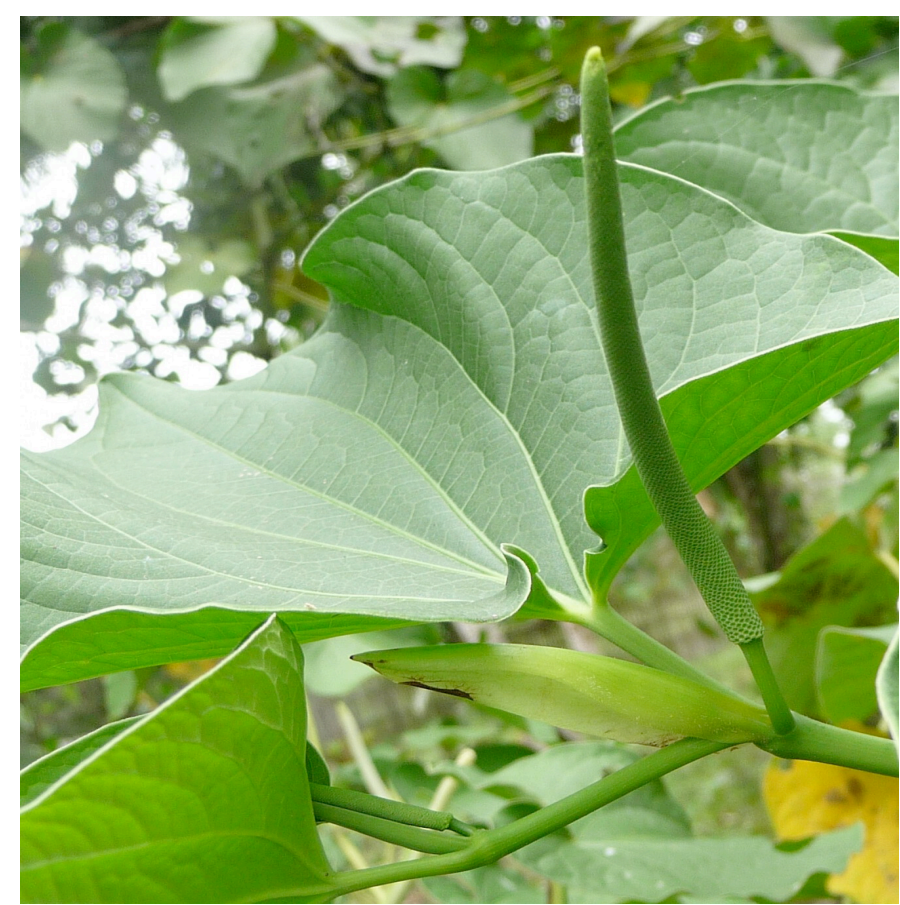

Figure 3-42. Inflorescence on a small tree habitus, green stem, very long internode, Piper wichimannii (Photo by KMB Kameubun) 


\section{3-2-2. Description of the Wati plant in botanical terms}

\section{3-2-2-1. Description of the cultivars of Piper methysticum Forst. species}

1. cultivar: Wati Kuning (Figure 3-43).

Shrub habitus and grows up to $2 \mathrm{~m}$. It has a tap root. Stem: oval form, nodes, internodes $4-14 \mathrm{~cm}$, green color, and it has cambium. It has a single leaf, the leaf is spreading, a short stalk $(1-2,5 \mathrm{~cm})$, green color, has a sheath, the sheath length reaches $3.5 \mathrm{~cm}$ and the width is $1-3 \mathrm{~cm}$. The leaf colour is goldish-yellow to green, the leaf is slippery, thickish, soft, fairly rigid, heart-shaped, the length of the leaves is $8.5-16 \mathrm{~cm}$ and the width of the leaves $7.5-11,5 \mathrm{~cm}$. They have a dimpled base, the leaves have curve-shaped main veins up to the tip of the leaf, and falling leaves leave a ring-shaped mark on the stem.

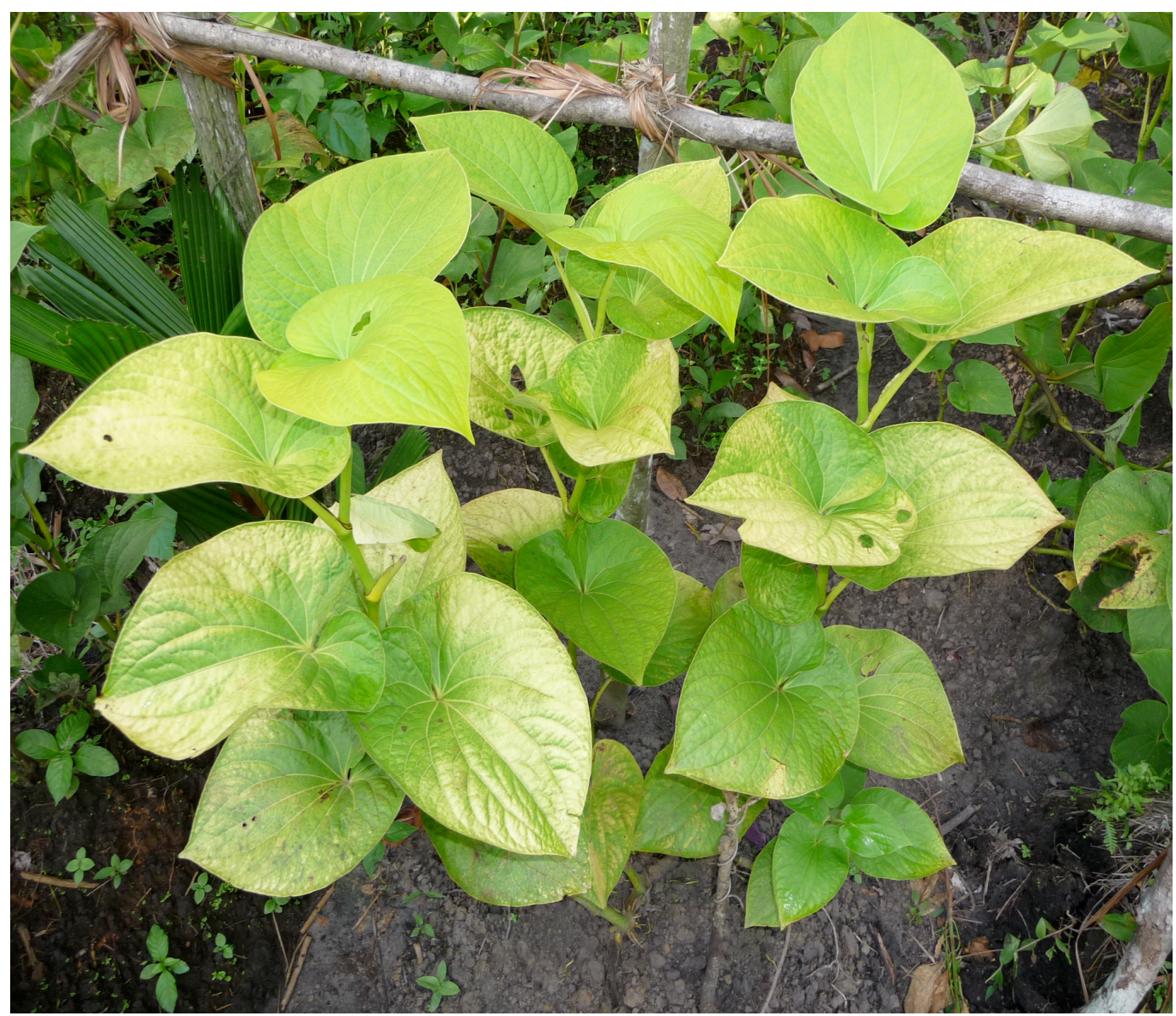

Figure 3-43. cultivar Wati Kuning (Photo by KMB Kameubun) 


\section{2. cultivar: Safurawe (Figure 3-44).}

Shrub habitus and grows up to $2 \mathrm{~m}$. It has a tap root. Stem: oval form, node, internodes, length of internodes $4-14 \mathrm{~cm}$, green color, and it has cambium. The branching appears on stem internodes covered by a leaf sheath. There is a single leaf, the leaf is spreading, the stalk is short $(1-2.5 \mathrm{~cm})$, the color is green. It has a sheath, the length of which reaches up to $3.5 \mathrm{~cm}$, the width is $1-3 \mathrm{~cm}$. The leaves are green, slippery, thickish, soft, heart-shaped. The length of the leaves is $8.5-16 \mathrm{~cm}$, the width is $7.5-11,5 \mathrm{~cm}$. The base is dimpled, the leaves have curve-shaped main veins up to the tip of the leaf, Falling leaves leave a ringshaped mark on the stem. Sometimes a new bud appears from stem node after the leaves fall off.

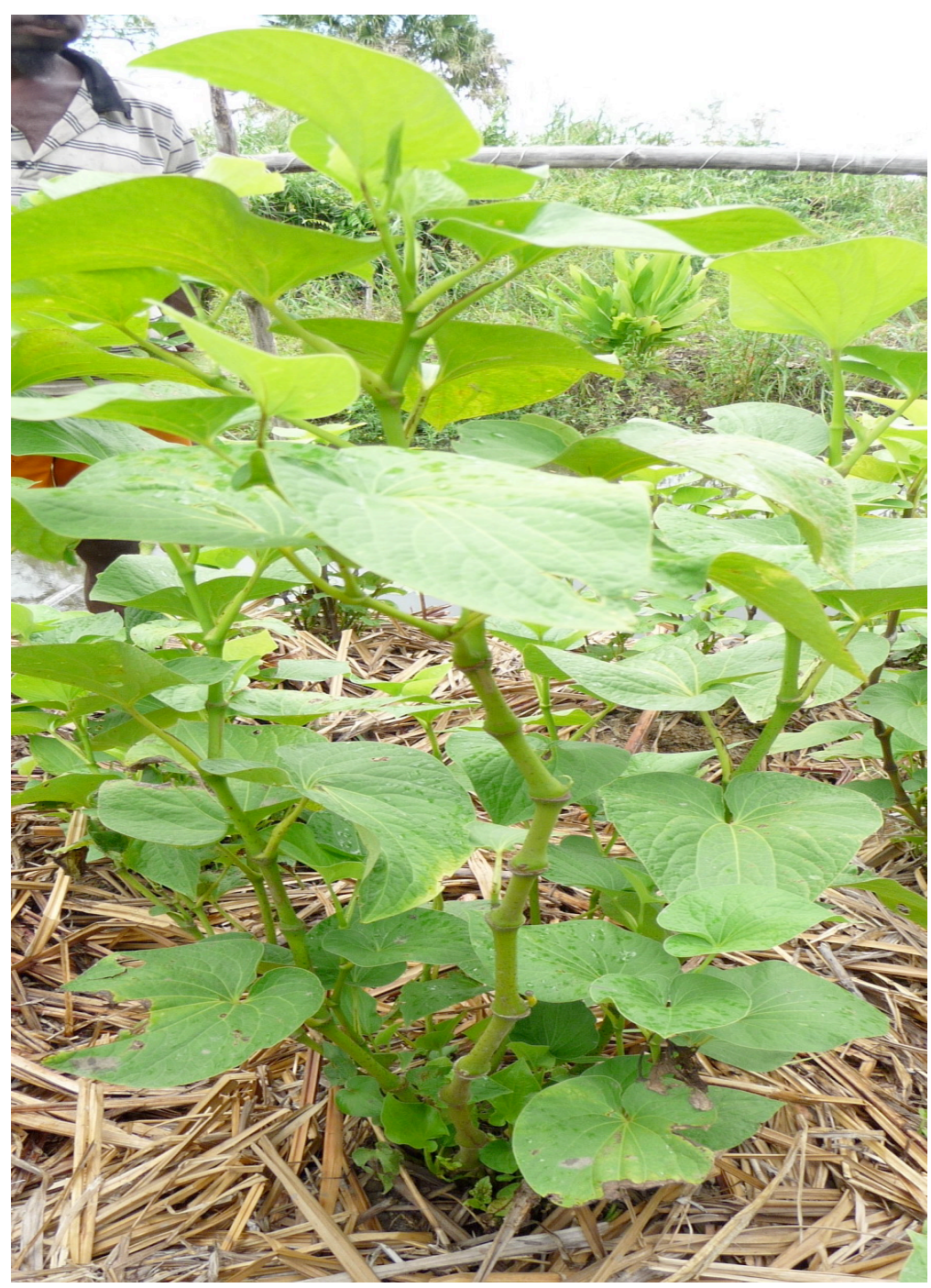

Figure 3-44. cultivar Safurawe (Photo by KMB Kameubun) 


\section{3. cultivar: Munana (Figure 3-45).}

Shrub habitus and grows up to $2 \mathrm{~m}$. It has a tap root. Stem: Oval, node, internodes, length of internodes $>12-14 \mathrm{~cm}$, green color, it has cambium. The branching appears on the stem internodes covered by sheath leaves. There is a single leaf, the leaf is spreading, the stalk of leaves is $1-2.5 \mathrm{~cm}$ long, the color is green, it has a sheath the length of which reaches $3.5 \mathrm{~cm}$, the width is $1-3 \mathrm{~cm}$. The leaf colour is green, the leaves are slippery, thickish, soft, heart-shaped. The leaf length is $>16-25 \mathrm{~cm}$, the width is $13-20 \mathrm{~cm}$. The base is dimpled, the leaves have curve-shaped main veins up to the tip of the leaf. The falling leaves leave a ring-shaped mark on the stem. Sometimes a new bud appears from stem node after the leaves fall off.

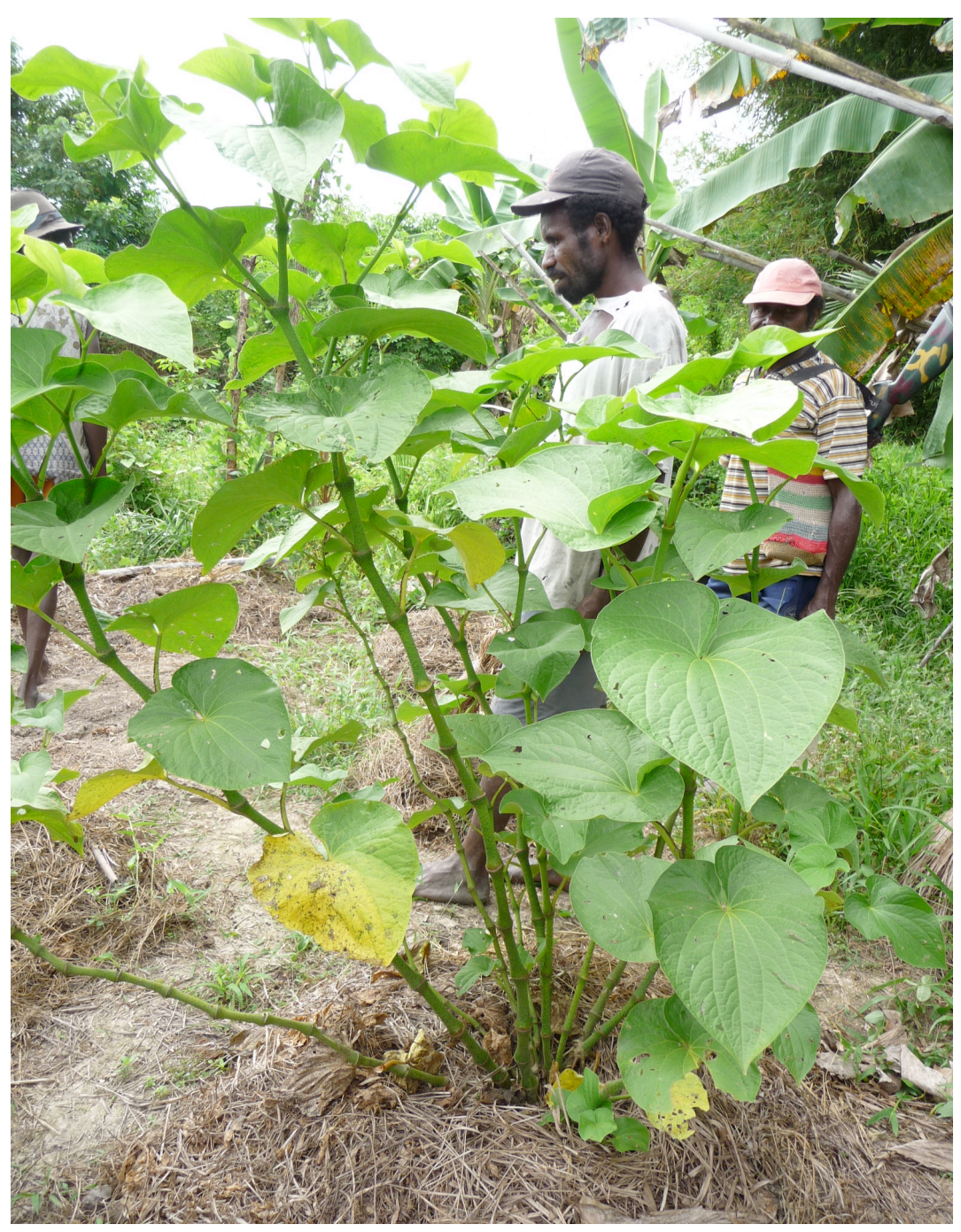

Figure 3-45. cultivar Munana (Photo by KMB Kameubun) 


\section{4. cultivar Palima (Figure 3-46).}

Shrub habitus and grows up to $2 \mathrm{~m}$. It has a tap root. Stem: Oval, node, internodes, length of internodes $2-11 \mathrm{~cm}$, brownish - red color, it has cambium. The branching appears on stem internodes covered by sheath leaves. Stipula grow up from the base of a branch internode, the colour of stipula is light yellow, there are brownish-red spots on the stipula (Figure 3-33). There is a single leaf, the leaf is spreading, the leaf stalk is $1-1.5 \mathrm{~cm}$ long, the color is reddish - green, it has a sheath the length of which reaches up to $3 \mathrm{~cm}$, the width is $1-2.5 \mathrm{~cm}$. The leaves are of green color, slippery, soft, heart-shaped. The leaf length is $14.5-19 \mathrm{~cm}$ and the width is $11-16 \mathrm{~cm}$. The base is dimpled, the leaves have curve-shaped main veins up to the tip of the leaf. The falling leaves leave a ring-shaped mark on the stem. Sometimes a new bud appears from stem node after the leaves fall off. The length of the inflorescence reaches up to $2 \mathrm{~cm}$ (Figure 3-41).

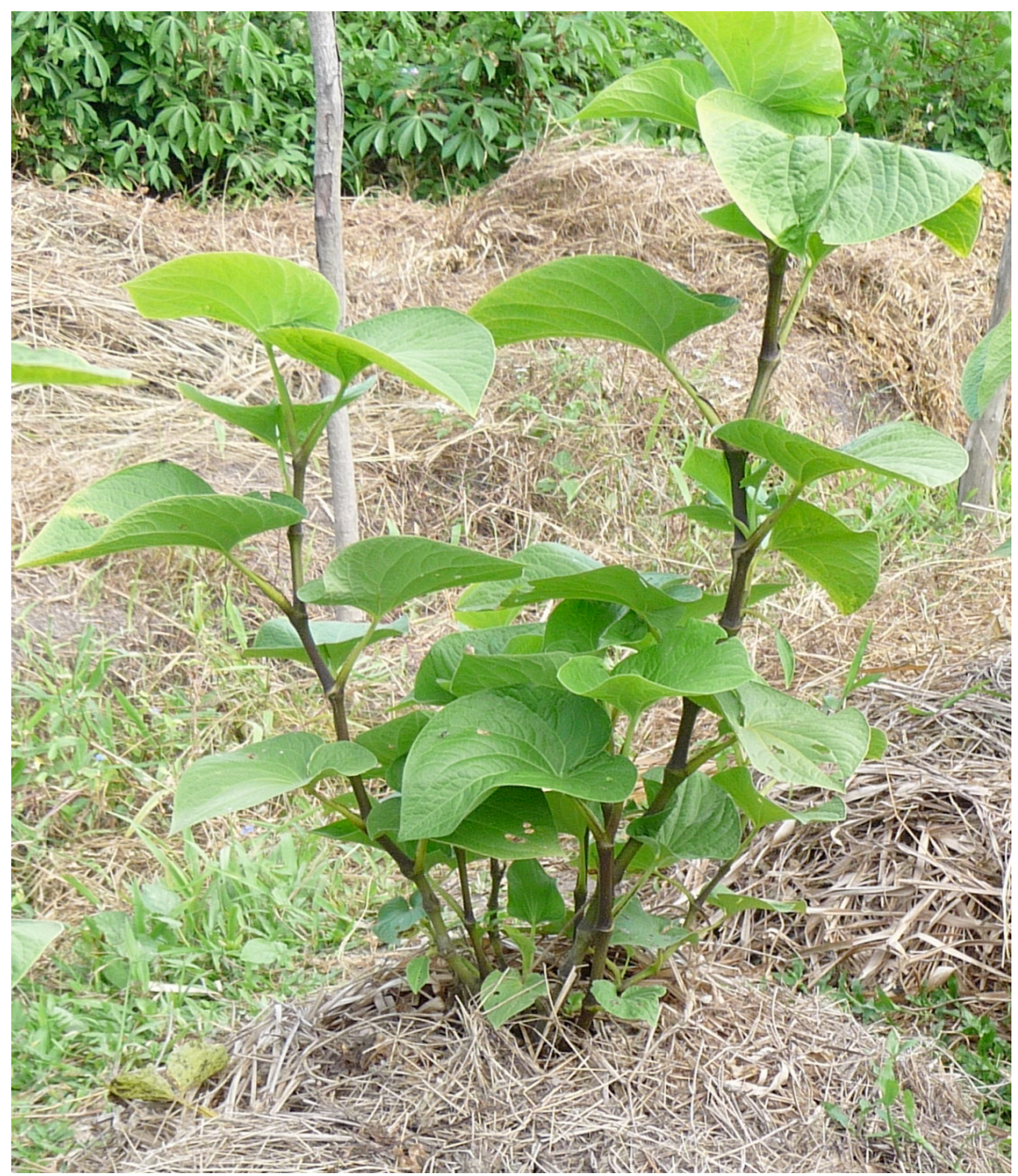

Figure 3-46. cultivar Palima (Photo by KMB Kameubun) 


\section{5. cultivar Babid (Figure 3-47).}

Shrub habitus and grows up to $1 \mathrm{~m}$. It has a tap root. Stem: Oval, node, internodes, length of internodes $2-8 \mathrm{~cm}$, brownish - red color, it has cambium. The branching appears on stem internodes covered by sheath leaves. There is a single leaf, the leaf is spreading, the leaf stalk is $1-2 \mathrm{~cm}$, the color is reddish green, The sheath length is $3 \mathrm{~cm}$, the width is $1-3 \mathrm{~cm}$. The color of the leaves is green, they are slippery, soft, heart-shaped. The leaf length is $13-16 \mathrm{~cm}$, the width is $10-13 \mathrm{~cm}$. The base is dimpled, the leaves have curve-shaped main veins up to the tip of the leaf. The falling leaves leave a ring-shaped mark on the stem. Sometimes a new bud appears from stem after the leaves fall off.

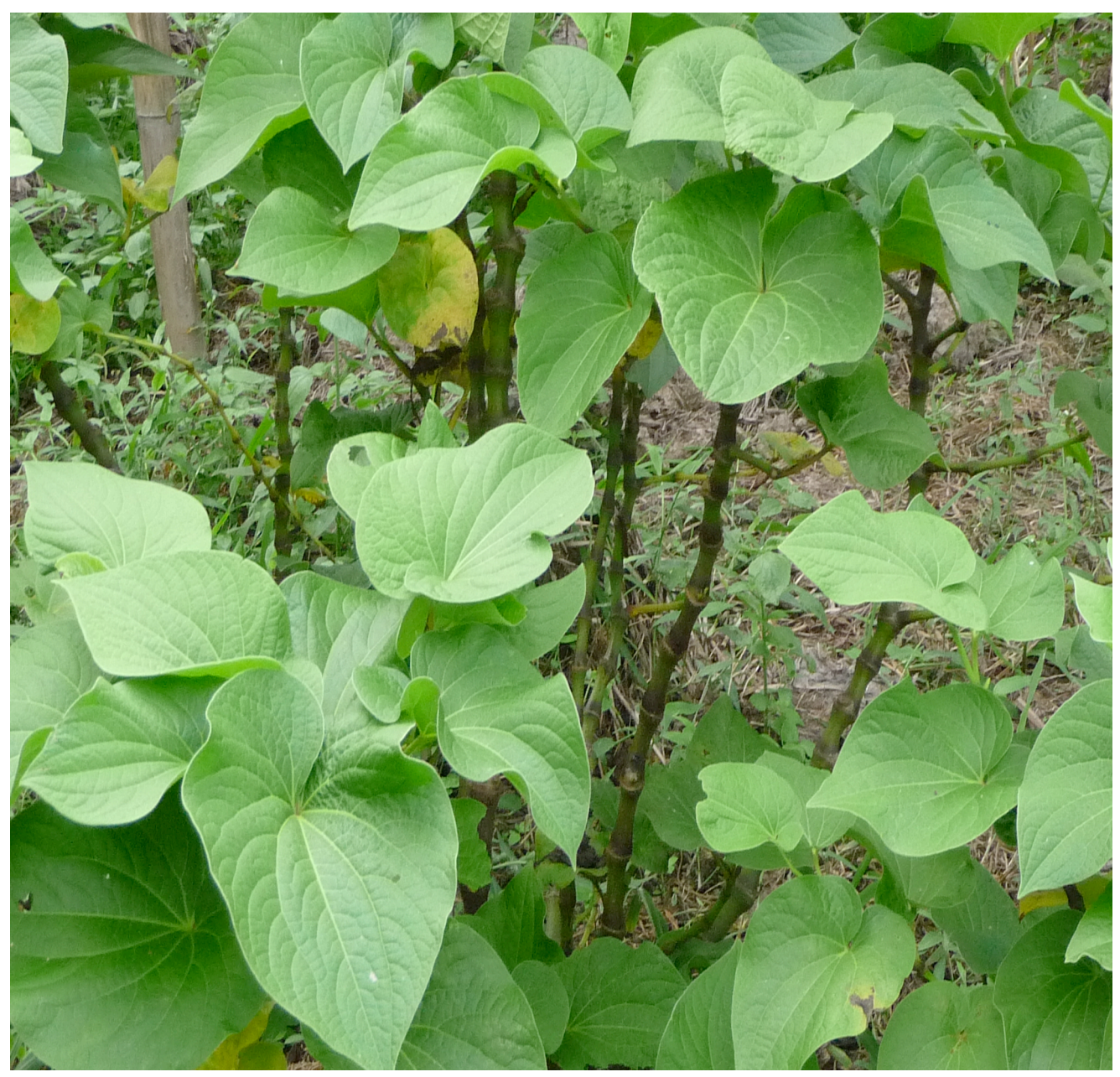

Figure 3-47. cultivar Babid (Photo by KMB Kameubun) 
3-2-2-2. Description of Piper wichimannii C.DC. (Figure 3-48).

Small tree habitus, and grows up to $4-5 \mathrm{~m}$. It has a tap root. Stem: Oval, node, internodes, length of internodes $15 \mathrm{~cm}$, green color, it has cambium. The branching appears on the base of stem internodes covered by a sheath leaf. At the point of branching there are stipula appearing from the base of stem internodes. The color of the stipula is light yellow (Figure 3-33). There is a single leaf, the leaf is spreading, the leaf stalk is $1.5-3 \mathrm{~cm}$ long, the color is green, it has a sheath the length of which reaches $4 \mathrm{~cm}$, the width is $1-4 \mathrm{~cm}$. The leaves are of green colour, slippery, soft, heart-shaped. The leaf length is $10-16 \mathrm{~cm}$, the width is $8-$ $12 \mathrm{~cm}$. The base is dimpled, the leaves have curve-shaped main veins up to the tip of the leaf. The falling leaves leave a ring-shaped mark on the stem. The length of the inflorescence reaches more than $8 \mathrm{~cm}$ (Figure 3-42).

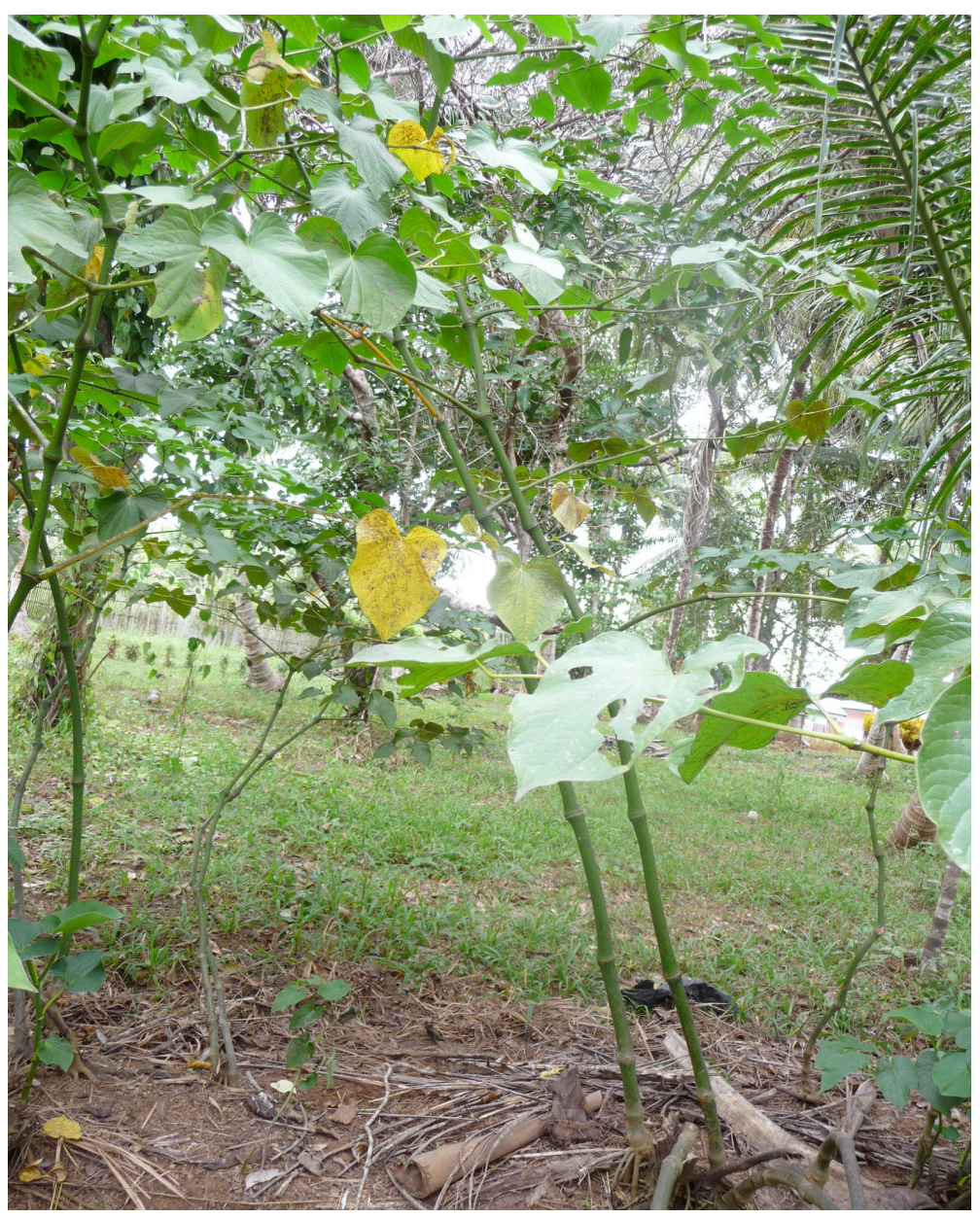

Figure 3-48. Piper wichimannii (Photo by KMB Kameubun) 


\section{3-2-3. Determination key}

1a. Green stem …......................................................................... 2

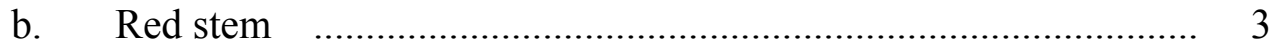

2a. Small tree habitus, height reaches $5 \mathrm{~m}$, many lenticels on the stem Piper wichimannii

b Shrub habitus, height reaches $2 \mathrm{~m}$.............................................. 4

3a. Herb habitus, height reaches $1 \mathrm{~m}$, rather stiff leaf, rather thick leaf Piper methysticum cultivar Babid

b. Shrub habitus, height reaches $2 \mathrm{~m}$, lenght of stem internode $2-11 \mathrm{~cm}$, lenght of inflorescences $>2 \mathrm{~m}$ Piper methysticum cultivar Palima

4a. lenght of stem internode $>12-14 \mathrm{~cm}$, few lenticels on the stem Piper methysticum cultivar Munana

b. lenght of stem internode $>4-14 \mathrm{~cm}$, 5

5a. no lenticels on the stem, green leaf, rather thick, rather soft, Piper methysticum cultivar Safurawe

b. no lenticels in the stem, leaf colour is goldish-yellow green rather thick, rather stiff Piper methysticum cultivar Wati Kuning

Differences between Piper wichimannii and Piper methysticum with the cultivars of Piper methysticum are listed in table 3-8 and about 70 local names used by People of Marind Land (Marind Darat / Marind degh), Marind Swamp (Marind Rawa / Marind bob) and Marind Beach (Marind Pantai / Marind dufh). They are classified into 5 cultivars of Piper methysticum Forst and Piper wichimannii C.DC. These are (table 3-9): 


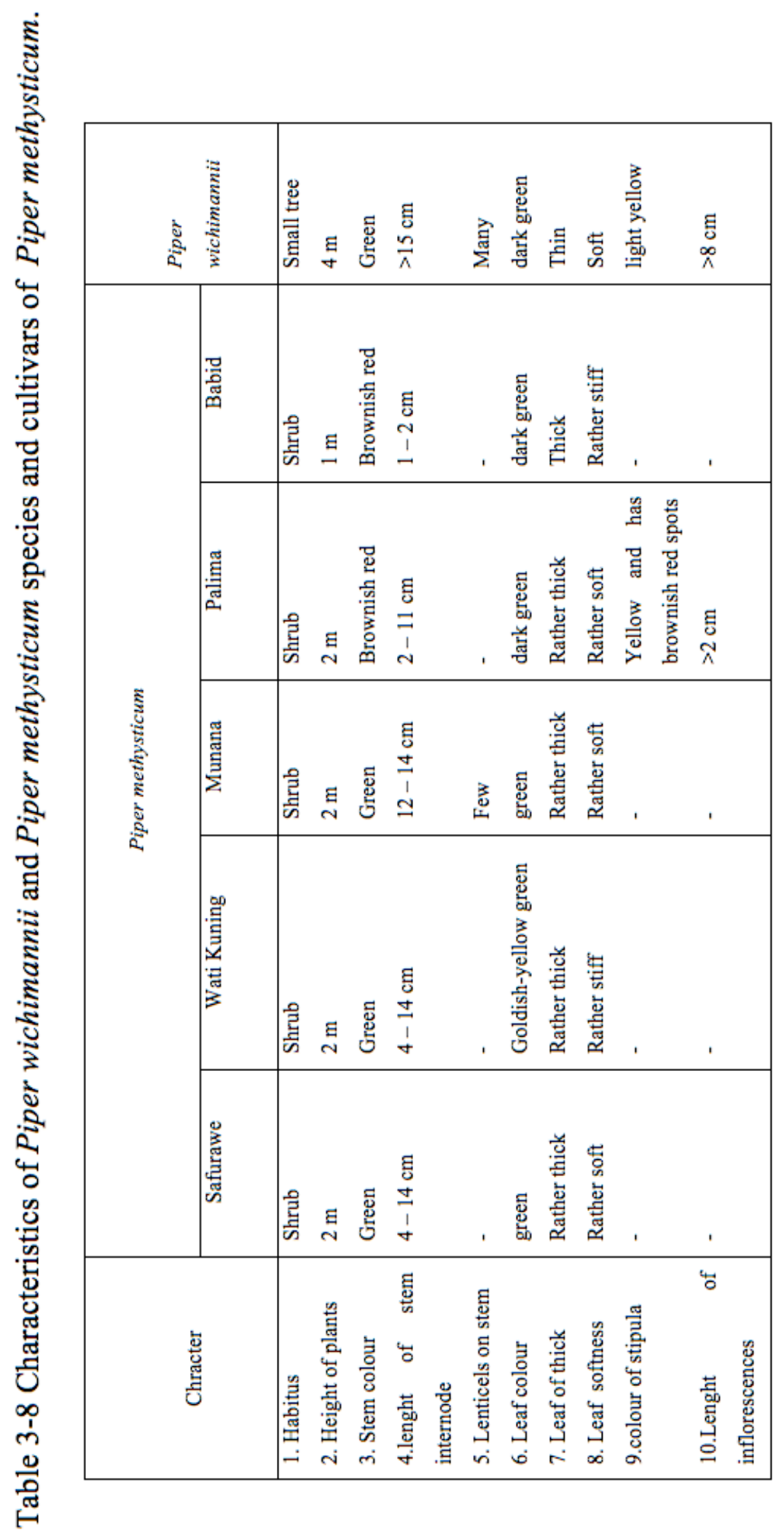


Table 3-9. Classification of local names of the Wati plant based on Botanical scientific names and distibution of these cultivars in Marind Land (Marind Darat / Marind degh), Marind Swamp (Marind Rawa / Marind bob), and Marind Beach (Marind Pantai / Marind dufh) areas.

\begin{tabular}{|c|c|c|c|c|c|c|}
\hline \multirow[b]{2}{*}{ Species } & \multirow[b]{2}{*}{ Local name } & \multirow[b]{2}{*}{$\begin{array}{l}\text { Culti- } \\
\text { vation }\end{array}$} & \multirow[b]{2}{*}{ Village name } & \multicolumn{3}{|c|}{ Marind } \\
\hline & & & & $\begin{array}{l}\text { Land/ } \\
\text { Darat }\end{array}$ & $\begin{array}{l}\text { Beach/ } \\
\text { Pantai }\end{array}$ & $\begin{array}{c}\text { Swamp/ } \\
\text { Rawa }\end{array}$ \\
\hline \multirow[t]{2}{*}{$\begin{array}{l}\text { 1. Piper } \\
\text { methysticum } \\
\text { Cultivar Wati } \\
\text { Kuning }\end{array}$} & Wati kuning & Yes & $\begin{array}{l}\text { Bamol 1, Bamol } \\
2\end{array}$ & & & $\sqrt{ }$ \\
\hline & Sipul & Yes & $\begin{array}{l}\text { Bibikem, } \\
\text { Dufmirah }\end{array}$ & $\sqrt{ }$ & $\sqrt{ }$ & \\
\hline \multirow[t]{19}{*}{$\begin{array}{l}\text { 2. Piper } \\
\text { methysticum } \\
\text { Cultivar } \\
\text { Safurawe }\end{array}$} & $\begin{array}{l}\text { Amnanggip } \\
\text { bolawe }\end{array}$ & Yes & Domande & & $\sqrt{ }$ & \\
\hline & Badbed & No & $\begin{array}{l}\text { Sanggase,Alaku, } \\
\text { Alatep }\end{array}$ & & $\sqrt{ }$ & \\
\hline & $\begin{array}{l}\text { Bademid/wati } \\
\text { kuning }\end{array}$ & Yes & Yawimu & $\sqrt{ }$ & & \\
\hline & Besal & No & Yanggandur & $\sqrt{ }$ & & \\
\hline & Biddabedhi & Yes & Wambi & & $\sqrt{ }$ & \\
\hline & Dokide & No & Bibikem & $\sqrt{ }$ & & \\
\hline & Homsakih & No & Dufmirah & & $\sqrt{ }$ & \\
\hline & Housah & No & Dufmirah & & $\sqrt{ }$ & \\
\hline & $\begin{array}{l}\text { Injimu } \\
\text { kwadara }\end{array}$ & Yes & $\begin{array}{l}\text { Kimaam,Kiworo, } \\
\text { Woner,Mambun }\end{array}$ & & & $\sqrt{ }$ \\
\hline & Kambiru & No & Kaliki & $\sqrt{ }$ & & \\
\hline & Kodara & Yes & $\begin{array}{l}\text { Bamol 1\&2, } \\
\text { Yomuka }\end{array}$ & & & $\sqrt{ }$ \\
\hline & Kuadara & Yes & Iromoro & & & $\sqrt{ }$ \\
\hline & Kuasanggap & No & Baad & $\sqrt{ }$ & & \\
\hline & Mbasom & No & Bibikem & $\sqrt{ }$ & & \\
\hline & Meve patul & No & Koa & $\sqrt{ }$ & & \\
\hline & $\begin{array}{l}\text { Meve } \\
\text { qiwasom }\end{array}$ & No & Koa & $\sqrt{ }$ & & \\
\hline & Namuara & Yes & $\begin{array}{l}\text { Kimaam,Kiworo, } \\
\text { Woner,Mambun }\end{array}$ & & & $\sqrt{ }$ \\
\hline & Namur & No & Wambi & & $\sqrt{ }$ & \\
\hline & Namuru & Yes & $\begin{array}{l}\text { Bamol } \\
1 \& 2, \text { Iromoro }\end{array}$ & & & $\sqrt{ }$ \\
\hline
\end{tabular}




\begin{tabular}{|c|c|c|c|c|c|c|}
\hline \multirow[b]{2}{*}{ Species } & \multirow[b]{2}{*}{ Local name } & \multirow[b]{2}{*}{$\begin{array}{l}\text { Culti- } \\
\text { vation }\end{array}$} & \multirow[b]{2}{*}{ Village name } & \multicolumn{3}{|c|}{ Marind } \\
\hline & & & & $\begin{array}{l}\text { Land/ } \\
\text { Darat }\end{array}$ & $\begin{array}{l}\text { Beach/ } \\
\text { Pantai }\end{array}$ & $\begin{array}{l}\text { Swamp/ } \\
\text { Rawa }\end{array}$ \\
\hline & Ndikpu & No & Bibikem & $\sqrt{ }$ & & \\
\hline & $\begin{array}{l}\text { Nten mber- } \\
\text { mber }\end{array}$ & Yes & Sota & $\sqrt{ }$ & & \\
\hline & Otakon & Yes & Baad & $\sqrt{ }$ & & \\
\hline & Prahteh & No & Yanggandur & $\sqrt{ }$ & & \\
\hline & Safurawe & Yes & Kaliki & $\sqrt{ }$ & & \\
\hline & Sah Ulawe & No & Kaiburse,Onggari & & $\sqrt{ }$ & \\
\hline & Sah walawe & Yes & Makaling,Domande & & $\sqrt{ }$ & \\
\hline & Sakalo & Yes & Kindiki & $\sqrt{ }$ & & \\
\hline & Sakaro & Yes & Saror & $\sqrt{ }$ & & \\
\hline & Salwak & Yes & Yawimu & $\sqrt{ }$ & & \\
\hline & Sipur & No & Kaliki & $\sqrt{ }$ & & \\
\hline & $\begin{array}{l}\text { Tampar mber- } \\
\text { mber }\end{array}$ & Yes & Sota & $\sqrt{ }$ & & \\
\hline & Tuband & No & Kaliki,Kindiki & $\sqrt{ }$ & & \\
\hline & Ulawe & Yes & Kaiburse,Onggari & & $\sqrt{ }$ & \\
\hline & Urawe & Yes & Koa & $\sqrt{ }$ & & \\
\hline & Walawe & Yes & Makaling,Dufmirah & & $\sqrt{ }$ & \\
\hline & Walwe & Yes & $\begin{array}{l}\text { Yomop,Sanggase, } \\
\text { Alaku, Alatep }\end{array}$ & $\sqrt{ }$ & $\sqrt{ }$ & \\
\hline & Wati & Yes & $\begin{array}{l}\text { Saror,Urumb,Matara, } \\
\text { Kuper,Imbuti }\end{array}$ & $\sqrt{ }$ & $\sqrt{ }$ & \\
\hline & Welmiemie & No & Bibikem & $\sqrt{ }$ & & \\
\hline & Yone & No & Kaliki & $\sqrt{ }$ & & \\
\hline $\begin{array}{l}\text { 3. Piper } \\
\text { methysticum } \\
\text { Cultivar Babid }\end{array}$ & Babid & Yes & Domande & & $\sqrt{ }$ & \\
\hline & Babin & Yes & Wambi,Dufmirah, & & $\sqrt{ }$ & \\
\hline & Babind & No & $\begin{array}{l}\text { Makaling,Yawimu, } \\
\text { Sanggase,Alaku, } \\
\text { Alatep }\end{array}$ & $\sqrt{ }$ & $\sqrt{ }$ & \\
\hline & Bambind & Yes & Bibikem & $\sqrt{ }$ & & \\
\hline & Besel & No & Sota & $\sqrt{ }$ & & \\
\hline & Ndikawi & Yes & Yomuka & & & $\sqrt{ }$ \\
\hline & Ndikay & Yes & $\begin{array}{l}\text { Kimaam,Kiworo, } \\
\text { Woner,Mambun }\end{array}$ & & & $\sqrt{ }$ \\
\hline & Ndikayu & Yes & Bamol 1\&2,Iromoro & & & $\sqrt{ }$ \\
\hline
\end{tabular}




\begin{tabular}{|c|c|c|c|c|c|c|}
\hline \multirow[b]{2}{*}{ Species } & \multirow[b]{2}{*}{$\begin{array}{l}\text { Local } \\
\text { name }\end{array}$} & \multirow[b]{2}{*}{$\begin{array}{l}\text { Culti- } \\
\text { vation }\end{array}$} & \multirow[b]{2}{*}{ Village name } & \multicolumn{3}{|c|}{ Marind } \\
\hline & & & & $\begin{array}{l}\text { Land/ } \\
\text { Darat }\end{array}$ & $\begin{array}{l}\text { Beach/ } \\
\text { Pantai }\end{array}$ & $\begin{array}{c}\text { Swamp/ } \\
\text { Rawa }\end{array}$ \\
\hline \multirow[t]{3}{*}{$\begin{array}{l}\text { 4. Piper } \\
\text { methysticum } \\
\text { Cultivar } \\
\text { Munana }\end{array}$} & Benetre & Yes & Yanggandur & $\sqrt{ }$ & & \\
\hline & Munana & Yes & Makaling & & $\sqrt{ }$ & \\
\hline & Pacaka & Yes & $\begin{array}{l}\text { Kimaam,Kiworo, } \\
\text { Woner,Mambun }\end{array}$ & & & $\sqrt{ }$ \\
\hline \multirow[t]{11}{*}{$\begin{array}{l}\text { 5. Piper } \\
\text { methysticum } \\
\text { Cultivar Palima }\end{array}$} & Besel & No & Sota & $\sqrt{ }$ & & \\
\hline & Deago & No & Muting & $\sqrt{ }$ & & \\
\hline & Donggar & No & Kaliki & $\sqrt{ }$ & & \\
\hline & Ekawati & Yes & Yomuka & & & $\sqrt{ }$ \\
\hline & Kuraka & Yes & Bamol 1\&2,Iromoro & & & $\sqrt{ }$ \\
\hline & Kwadara & Yes & $\begin{array}{l}\text { Kimaam,Kiworo, } \\
\text { Woner,Mambun }\end{array}$ & & & $\sqrt{ }$ \\
\hline & Namol & Yes & Bibikem & $\sqrt{ }$ & & \\
\hline & Palima & Yes & $\begin{array}{l}\text { Makaling,Wambi, } \\
\text { Yawimu,Dufmirah, } \\
\text { Sanggase,Alaku, } \\
\text { Alatep,Domande } \\
\text { Imbuti,Kuper, } \\
\text { Kaiburse,Onggari } \\
\text { Wendu, Matara, } \\
\text { Urumb, Bahor, }\end{array}$ & $\sqrt{ }$ & $\sqrt{ }$ & \\
\hline & Parima & No & Kaliki & $\sqrt{ }$ & & \\
\hline & Purima & No & Yanggandur & $\sqrt{ }$ & & \\
\hline & Thomur & No & Yanggandur & $\sqrt{ }$ & & \\
\hline \multirow[t]{7}{*}{$\begin{array}{l}\text { 6. Piper } \\
\text { wichimannii } \\
\text { C.DC. }\end{array}$} & Bosamai & Yes & Muting & $\sqrt{ }$ & & \\
\hline & Kambilu & No & Makaling,Dufmirah & & $\sqrt{ }$ & \\
\hline & Malokwati & Yes & Kumaaf,Kindiki & $\sqrt{ }$ & & \\
\hline & Manom & No & $\begin{array}{l}\text { Sanggase,Alaku, } \\
\text { Alatep }\end{array}$ & & $\sqrt{ }$ & \\
\hline & Marub & Yes & Yanggandur & $\sqrt{ }$ & & \\
\hline & Mbui & No & Bibikem & $\sqrt{ }$ & & \\
\hline & Yambrate & Yes & Sota & $\sqrt{ }$ & & \\
\hline
\end{tabular}

Note: No: not planted, Yes: planted 


\section{3-2-4. Variety analysis of Wati plant morphological characteristics}

An analysis of the variety of the Wati plant in the area of Marind tribes is performed based on morphological features. The morphological characteristics comprise qualitative and quantitative features. A qualitative feature is a characteristic that can't be measured (non-matrix), in contrast to a quantitative feature (matrix). These features are called matrix variable and non-matrix variable. They were carried out on a characteristic specimen(table 3 - 10) and were conversed into a matrix that can be seen on table $3-11$ (appendix 6).

Table 3-10. Morphological characteristics of a matrix variable (qualitative) and non-matrix variable (quantitative) of the Wati plant in the Marind tribe area.

\begin{tabular}{|c|c|c|c|c|}
\hline No & Character scoring & 0 & 1 & 2 \\
\hline 1 & Habitus & Shrub & Small tree & \\
\hline 2 & Hight of plant & $\geq 1-2 \mathrm{~m}$ & $>3 \mathrm{~m}$ & \\
\hline 3 & Stem color & Green & Brownish red & \\
\hline 4 & Length of stem internode & $0-2 \mathrm{~cm}$ & $>2-14 \mathrm{~cm}$ & $>15 \mathrm{~cm}$ \\
\hline 5 & Spots on the stem & None & Few & Many \\
\hline 6 & Length of leaf stalk & $<12 \mathrm{~cm}$ & $>12-15 \mathrm{~cm}$ & \\
\hline 7 & Leaf length & $8,5-16 \mathrm{~cm}$ & $>16 \mathrm{~cm}-25 \mathrm{~cm}$ & \\
\hline 8 & Leaf width & $7,5-13 \mathrm{~cm}$ & $11-16 \mathrm{~cm}$ & \\
\hline 9 & Leaf color & Green & dark green & Yellowish-green \\
\hline 10 & Leaf thickness & Thin & Rather thick & Thick \\
\hline 11 & Leaf softness & Soft & Rather soft & Rather stiff \\
\hline 12 & Inflorescence & Short & Long & \\
\hline 13 & Length of inflorescence & $<2 \mathrm{~m}$ & $>8 \mathrm{~cm}$ & \\
\hline 14 & Color of stipula & light yellow & $\begin{array}{l}\text { Yellow spot dark } \\
\text { red }\end{array}$ & \\
\hline
\end{tabular}

A morphological feature analysis can only be carried out by using 14 morphological characteristics consisting of non-matrix variables and matrix 
variables (table $3-10$ ). Morphological characteristics number $12-14$ are features of the flower and the stipula only found in Piper wichimanni and Piper methysticum cultivar Palima in the field.

The result of the analysis of 14 morphological characteristics of both variables resulting in a dendogram is almost the same when using 3 different software programs. Those programs are statistics 8.0, and NTSYpc 2.02i.

\section{3-2-4-1. Analysis cluster using Statistica 8.0}

Based on an analysis by using Statistica 8.0 in similarity co- efficiency cut 3.0, there are 2 main groups of the Wati plant. Those are: (1). Piper wichimannii C.DC and (2). Piper methysticum Forst. The latter consists of three subgroups that are: Piper methysticum of Wati Kuning cultivar, Piper methysticum of Munana cultivar, Piper methysticum of Safurawe cultivar, Piper methysticum of Palima cultivar, Piper methysticum of Babid cultivar (Figure 3-49).

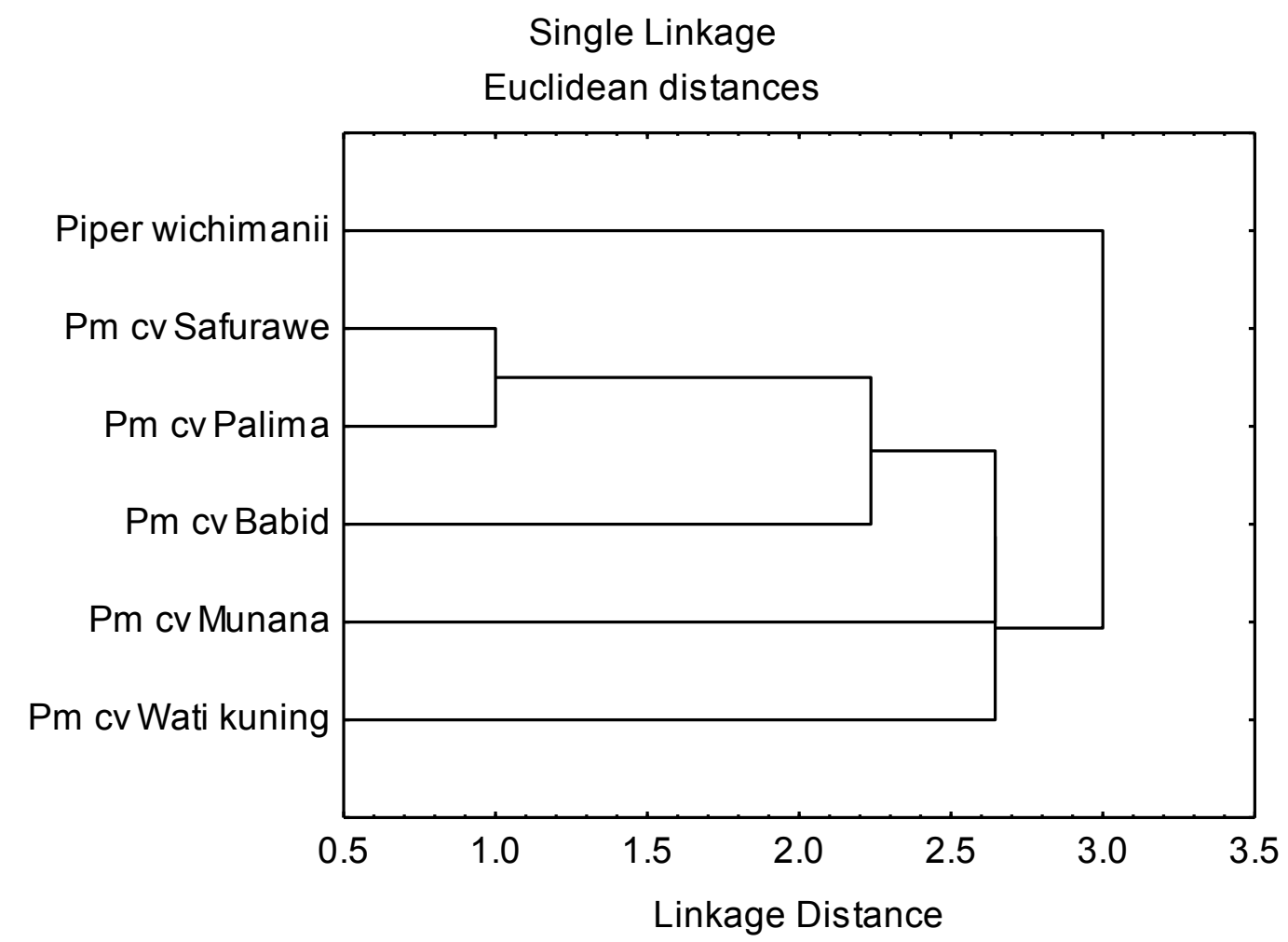

Figure 3-49. Dendogram of morphological similarity of the Wati plant (Piper wichimannii and Piper methysticum and its cultivars). Cluster analysis with Statistica 8.0 


\section{3-2-4-2. Cluster analysis using NTSYpc 2.20i}

The result of the analysis using NTSYpc 2.20i of similarity efficiency cut yielded efficiency 1.79. In the similarity efficiency cut, there are two large groups of the Wati plant: The first group is Piper wichimannii C.DC, the second group is Piper methysticum Forst. The second group consists of the first subgroup, Piper methysticum of Munana cultivar, the second sub group, Piper methysticum of Wati Kuning cultivar, and the third sub group, Piper methysticum of Safurawe cultivar, Piper methysticum of Palima cultivar, and Piper methysticum of Babid cultivar (Figure 3-50).

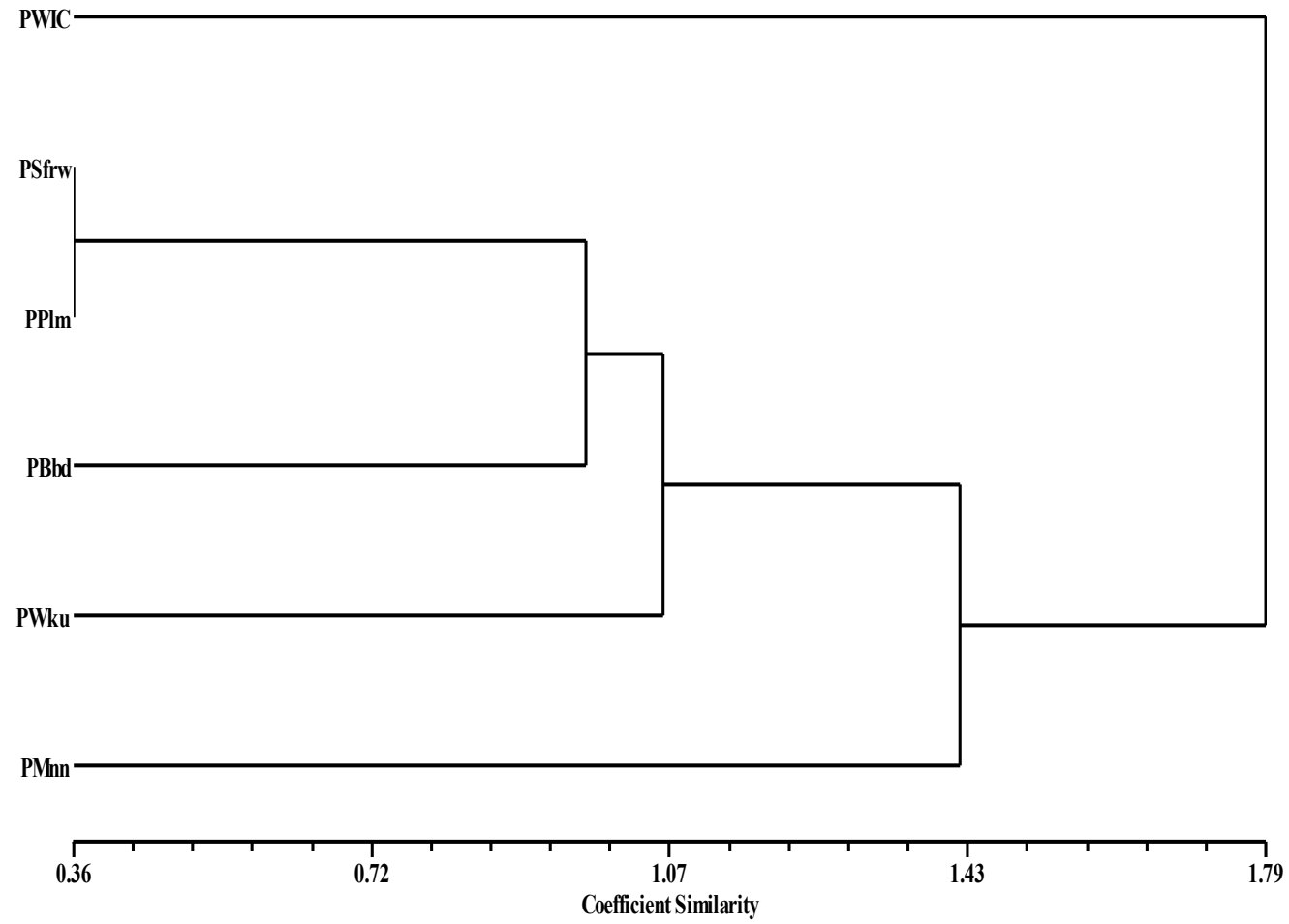

Figure 3-50. Dendogram of morphological similarity of the Wati plant (Piper wichimannii and Piper methysticum) and their cultivars of the result of the cluster analysis using NTSYSpc 2.02i. Explanations: $\mathrm{PWIC}=$ Piper wichimannii, $\mathrm{PSFw}=$ Piper methysticum cv Safurawe, PPlm= Piper methysticum cv Palima, $\mathrm{PBbd}=$ Piper methysticum cv Babid, PWku= Piper methysticum cv Wati Kuning, PMnn= Piper methysticum cv Munana. 
Based on a similarity matrix (appendix 6 ), the highest coefficient value was found in Piper methysticum between Safurawe cultivar and Palima cultivar and amounts to 0.91 . The lowest coefficient value was found between Piper wichimannii and Piper methysticum of Babid cultivar with a coefficient value of 0.1 .

\section{3-2-4-3. Main component analysis using NTSYSpc 2.20i}

The main component analysis of the Wati plant (Piper wichimannii and Piper methysticum and their cultivars) uses matrix variables (qualitative) and nonmatrix variables (quantitative) indicating an overall variety of $66.50 \%$. This value is yielded in 2 components resulting from the main component analysis (table 3 12).

Table 3-12. Main component analysis of the Wati plant (Piper wichimannii and Piper methysticum) from Merauke based on matrix variables (qualitative features) and non-matrix variables (quantitative features).

\begin{tabular}{cccc}
\hline \multirow{2}{*}{ Main component } & \multicolumn{3}{c}{ Eigen value } \\
\cline { 2 - 4 } & Total & Percentage (\%) & Cumulative (\%) \\
\hline 1 & 2.60939501 & 43.4899 & 43.4899 \\
2 & 1.38063042 & 23.0105 & 66.5004 \\
3 & 1.00278238 & 16.713 & 83.2135 \\
\hline
\end{tabular}

The Eigen value indicates a pattern formation of groups among the tested individuals. If 3 main groups are united into 3 axes $(X, Y, Z)$, the spread of the Wati plant from Merauke shows different distances (Figure 3 - 51). The distance among the nearest points indicates that the Wati groups (Piper wichimannii and Piper methysticum and their cultivars) have a high similarity, and the distance among the most distant points display the lowest similarity. 


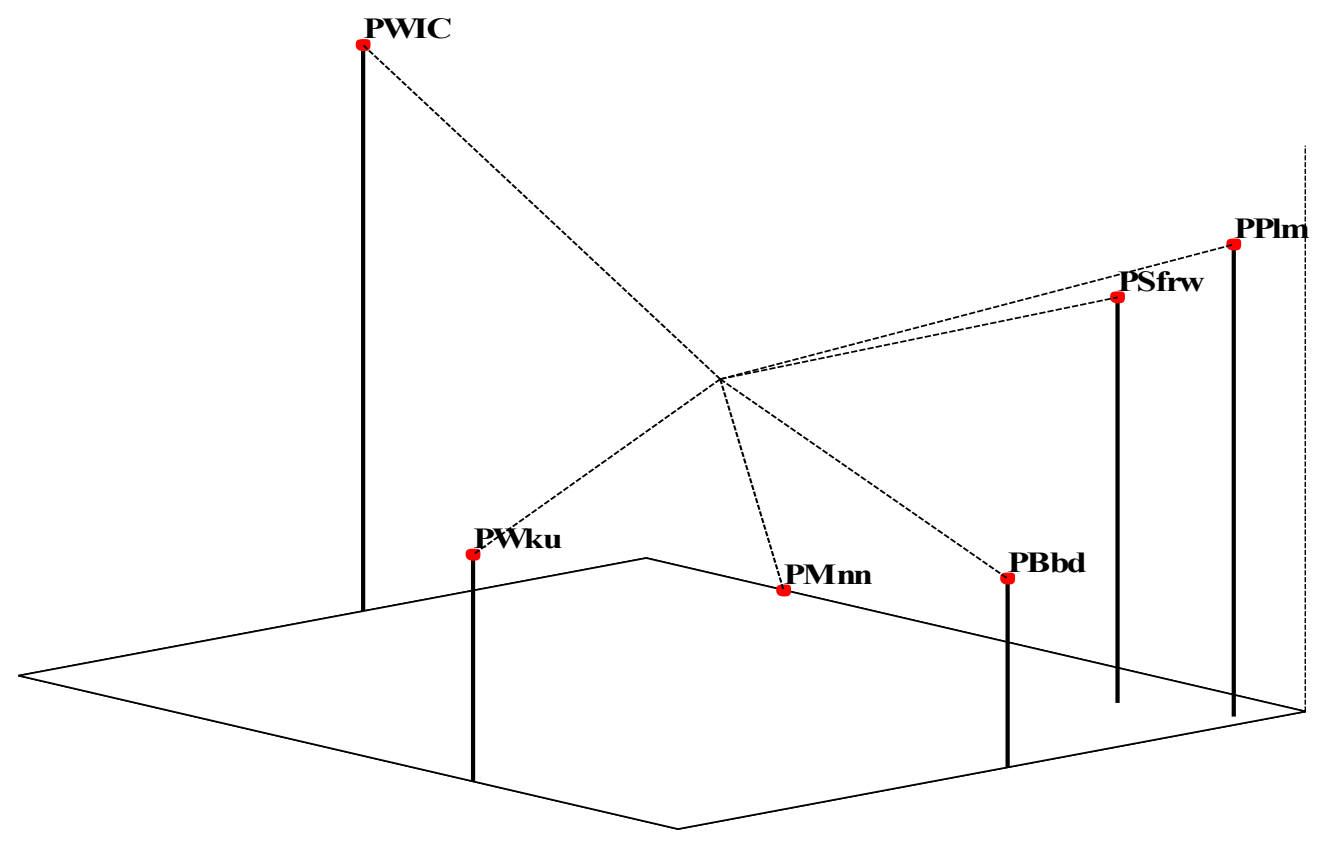

Figure 3-51. Plot of the score of the main components of the Wati plant (Piper wichimannii and Piper methysticum cultivar of Safurawe, Munana, Palima, Wati Kuning, and Babid). 


\section{3-3. GENETIC DIVERSITY USING MICROSATELLITE MARKERS}

\section{3-3-1. Genetic diversity and structure among species}

Genetic diversity of Kava or Wati plant (Piper methysticum, Piper wichimannii species) and Sirih (Piper betle) were studied using 3 nuclear microsatellite (nSSR) and 1 chloroplast microsatellite marker (cpSSR). The four microsatellites markers generated in total 23 different size fragments (in the case of nSSRs putative alleles). The size of each fragment generated by the different loci PN B5 (7 fragments), PN D10 (11 fragments), of PN G11 (9 fragments) and ccmp2 (3 haplotypes) is listed Table 3-13 andTable 3-15 (in appendix 7).

No variation was found in the putative allelic richness between the different cultivars of Piper methysticum but some fragments could be used for species identification. Number and size (in bp) of the fragments of each Piper methysticum cultivar and of the other Piper species are described in Table 3-13.

Table 3-13. Characteristics of nuclear microsatellite markers and one chloroplast marker of Piper methysticum cultivars, P. wichimannii and P. betle sampled in Marind tribe area.

\begin{tabular}{|c|c|c|c|c|c|}
\hline \multirow[t]{2}{*}{ Species \& cultivar } & \multicolumn{2}{|c|}{$\begin{array}{l}\text { Number of } \\
\text { alleles }\end{array}$} & \multirow{2}{*}{$\begin{array}{l}\text { Total } \\
\text { alleles }\end{array}$} & \multicolumn{2}{|c|}{$\begin{array}{l}\text { Fragment size range } \\
\text { (bp) }\end{array}$} \\
\hline & nSSRs & cpSSRs & & nSSRs & cpSSRs \\
\hline Piper methysticum & 9 & 1 & 10 & $203-257$ & 240 \\
\hline Cultivar Babid & 7 & 1 & 8 & $203-257$ & 240 \\
\hline Cultivar Safurawe & 8 & 1 & 9 & $203-257$ & 240 \\
\hline Cultivar Palima & 8 & 1 & 9 & $203-257$ & 240 \\
\hline Cultivar Munana & 8 & 1 & 9 & $203-257$ & 240 \\
\hline Cultivar Wati Kuning & 7 & 1 & 8 & $203-257$ & 240 \\
\hline Piper wichimannii & 11 & 1 & 12 & $201-258$ & 241 \\
\hline Piper betle & 17 & 2 & 19 & $199-262$ & $241-243$ \\
\hline
\end{tabular}

In each species different numbers of fragments were found; Piper methysticum (1 to 9 fragments) of nSSRs and (1 haplotype) of cpSSR, Piper wichimannii (2 to 7 fragments) of nSSRs and (1 haplotype) of cpSSR, Piper betle 
(5 to 7 fragments) of nSSRs and (2 haplotypes) of cpSSR (Table 3-14). One private fragment with a size of $219 \mathrm{bp}$ was found in the cultivar Palima of Piper methysticum (table 3-15 in appendix 7).

\section{3-3-2. Genetic diversity and structure within population}

The number of fragments for each locus of the analysed species and population derived from nSSRs marker and cpSSRs marker are presented in table 3-14.

Table 3-14. Characteristics of nuclear microsatellite markers and one chloroplast marker of different Piper species sampled in Marind tribe area.

\begin{tabular}{|c|c|c|c|c|c|c|c|c|c|c|c|}
\hline \multirow{3}{*}{$\begin{array}{l}\text { Repeat } \\
\text { type }\end{array}$} & \multirow{3}{*}{$\mathrm{Ta}(\mathrm{C})$} & \multirow{3}{*}{ Species } & \multirow{3}{*}{$\begin{array}{c}\text { Total alleles } \\
\text { per species } \\
\text { per locus }\end{array}$} & \multirow{3}{*}{$\begin{array}{c}\text { Total } \\
\text { alleles } \\
\text { per locus }\end{array}$} & \multirow{3}{*}{$\begin{array}{c}\text { Range } \\
\text { alleles } \\
\text { per locus }\end{array}$} & \multirow{2}{*}{\multicolumn{2}{|c|}{$\begin{array}{r}\text { Number of } \\
\text { Population }\end{array}$}} & \multirow[t]{2}{*}{ alleles } & \multicolumn{3}{|c|}{ Allele size range (bp) } \\
\hline & & & & & & & & & & Species & \\
\hline & & & & & & $\begin{array}{c}\text { Marind } \\
\text { Beach }\end{array}$ & $\begin{array}{l}\text { Marind } \\
\text { Land }\end{array}$ & $\begin{array}{l}\text { Marind } \\
\text { Swamp }\end{array}$ & $\begin{array}{c}\text { Piper } \\
\text { methysticum }\end{array}$ & $\begin{array}{l}\text { Piper } \\
\text { wichimannii }\end{array}$ & $\begin{array}{l}\text { Piper } \\
\text { betle }\end{array}$ \\
\hline \multirow[t]{3}{*}{ (TG)14 } & 53 & P. methysticum & 1 & 7 & 7 & 1 & 1 & 1 & 257 & \multirow{3}{*}{$257-258$} & \\
\hline & & P. wichimannii & 2 & & & 0 & 2 & 0 & & & \\
\hline & & P. betle & 5 & & & 3 & 4 & 2 & & & $253-262$ \\
\hline \multirow[t]{3}{*}{ (GT)13 } & 53 & P. methysticum & 9 & 11 & 11 & 7 & 6 & 8 & $202-219^{*}$ & & \\
\hline & & P. wichimannii & 7 & & & 0 & 7 & 0 & & \multirow[t]{2}{*}{$201-211$} & \\
\hline & & P. betle & 7 & & & 2 & 3 & 5 & & & 201-211 \\
\hline \multirow[t]{3}{*}{$(\mathrm{AC}) 5$} & 53 & P. methysticum & 5 & 9 & 2 & 2 & 4 & 5 & $203-211$ & \multirow{3}{*}{$203-211$} & \\
\hline & & P. wichimannii & 7 & & & 0 & 7 & 0 & & & \\
\hline & & P. betle & 7 & & & 7 & 6 & 7 & & & 199-209 \\
\hline \multirow[t]{3}{*}{ (A) 11} & 50 & P. methysticum & 1 & 3 & 3 & 1 & 1 & 1 & 240 & \multirow{3}{*}{241} & \\
\hline & & P. wichimannii & 1 & & & 0 & 1 & 0 & & & \\
\hline & & P. betle & 2 & & & 2 & 2 & 2 & & & $241-243$ \\
\hline
\end{tabular}

$\mathrm{Ta}$ (Annealing temperature), * (private allelle), $\mathrm{Na}$ (number of fragments),

\subsection{Piper betle}

1.1.1. Within the population of Piper betle for nSSRs 17 fragments were found and for cpSSRs 2 haplotypes. The most polymorphic locus was PN G11 with 7 fragments and locus PN D10 with 2 fragments was the lowest polymorphic locus and ccmp2 showed 2 different haplotypes. The size of the fragments ranged from $199-262 \mathrm{bp}$.

1.1.2. Concerning the genetic diversity among populations of the different Piper species, the highest number of polymorphic fragments were found for the locus PN G11 within the populations of Marind Beach and Marind Swamp. 
The locus PN B5 showed the lowest number of polymorphic fragments within the three different populations.

\subsection{Piper methysticum}

1.2.1. Within the population of Piper methysticum for nSSRs 11 fragments were found and for cpSSRs 1 haplotype. The most polymorphic locus was PN D10 with 8 fragments and locus PN D10 with 1 fragment was the lowest polymorphic locus and ccmp2 showed one haplotype.The size of the fragments ranged from $202-257 \mathrm{bp}$.

1.2.2. Concerning the genetic diversity among populations of the different Piper species, the highest number of polymorphic fragments were found for the locus PN D10 within the population of Marind Swamp. The locus PN B5 showed the lowest number of polymorphic fragments within the three different populations.

\subsection{Genetic diversity at nuclear and chloroplast microsatellite markers}

1. Within population diversity, The three polymorphic nuclear microsatellite markers generated a total of 20 fragments for the 3 species. The number of fragments per locus ranged from 2 for PN G11 to 11 for PN D10 (table 3-14). The highest polymorphic level was found in Piper methysticum for locus PN D10 with 9 fragments, Piper betle and Piper wichimannii showed for locus PN D10 and PN G11 7 fragments and Piper methysticum for locus PN G11 5 fragments.

The highest fragment frequency within the different Piper species was $48,73 \%$ for the fragment of 257 bp of locus PN B5 in Piper methysticum. The fragment frequencies for all nSSR loci and all species is shown in Figure 3-52, and Table 3-15 (appendix: 8). 


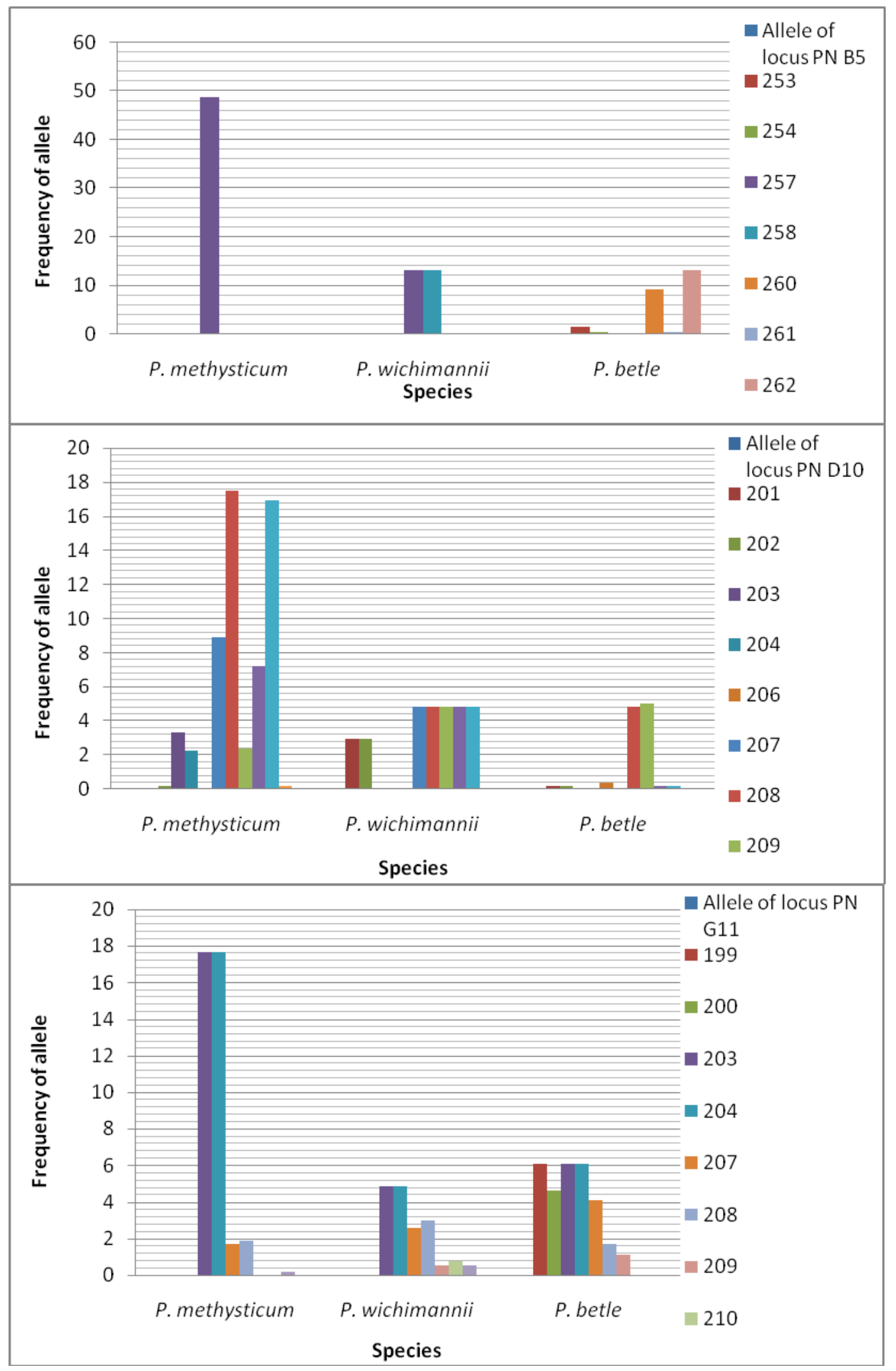

Figure 3-52. The fragment frequency of $3 \mathrm{nSSRs}$ loci in Piper methysticum, Piper wichimnnii and Piper betle. 
2. Genetic diversity among population of Piper species, The highest number of fragments per species per population were found in Piper methysticum of Marind Swamp with 9 fragments, followed by Marind Beach and Marind Land with 8 fragments. Piper wichimannii showed only in the population of Marind Land 11 fragments and Piper betle in the population of Marind Swamp 13 fragments, in the population of Marind Land 11 fragments and in the population of Marind Beach 10 fragments (Figure 3-53) were found of each species in Merauke Area.

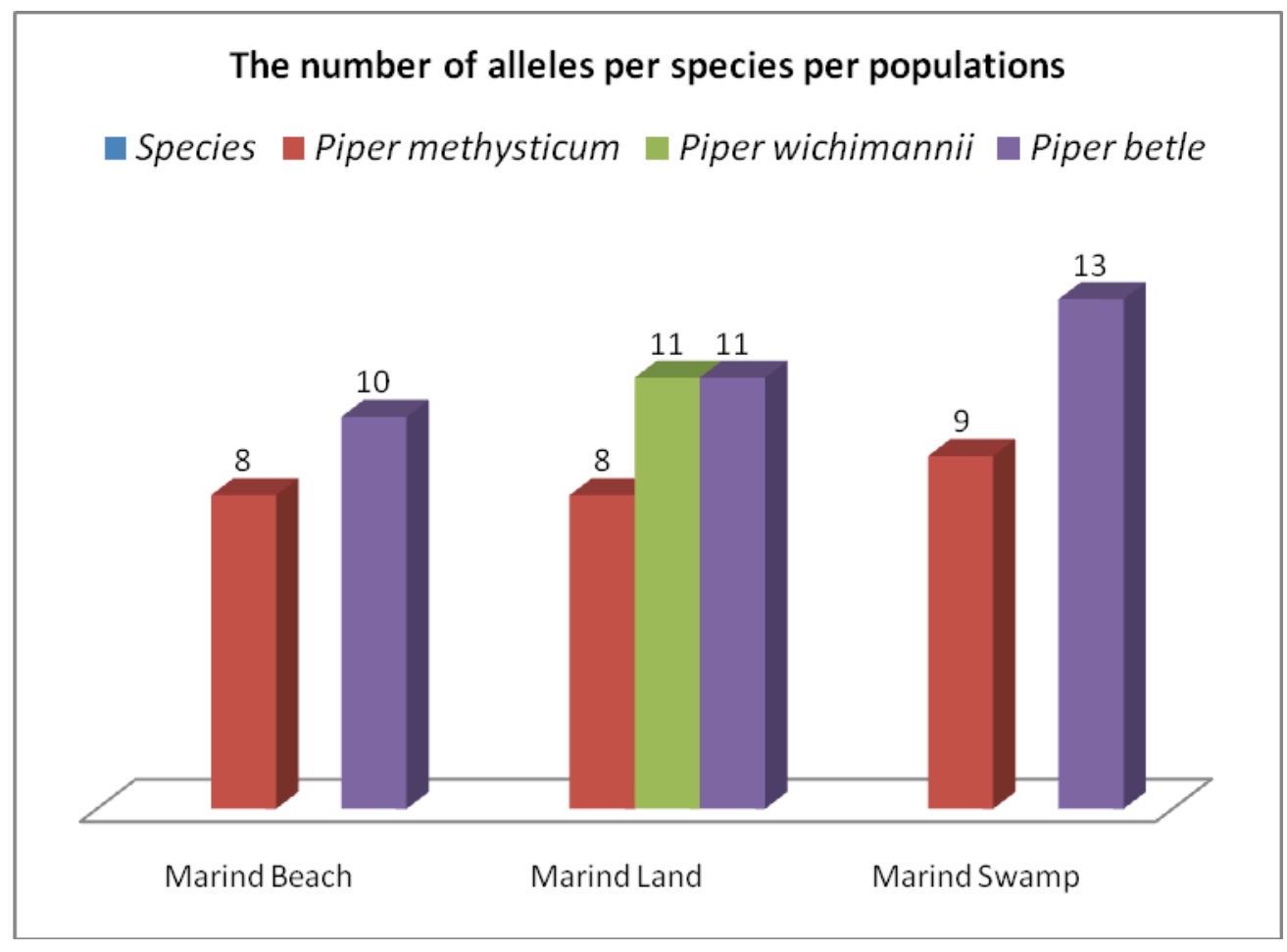

Figure 3-53. The total number of fragments based on species and populations on 3 nSSRs locus.

Only the population of Marind Beach had 1 private allele (219 bp locus PN D10) (table 3-15 in appendix 7) and Piper methysticum is monomorphic for locus PN B5.

The highest number of fragments was found for locus PN D10 in Piper methysticum; 8 in the population of Marind Swamp , 7 in the population of 
Marind Beach and 6 in the population of Marind Land. Only one fragment was found for locus PN B5 in Piper methysticum within all three populations.

The highest number of fragments (7 fragments) was found for locus PN D10 and PN G11 in Piper wichimannii. Two fragments were found for locus PN B5 in the population of Marind Land

The highest number of fragments was found for locus PN G11 in Piper betle; 7 in the populations of Marind Swamp and of Marind Beach. Two fragments were found for locus PN B5 in the populations of Marind Swamp and Marind Beach.Figure 3-54 and Table 3-15 (appendix 7) show the number of alleles for each species per locus and population.

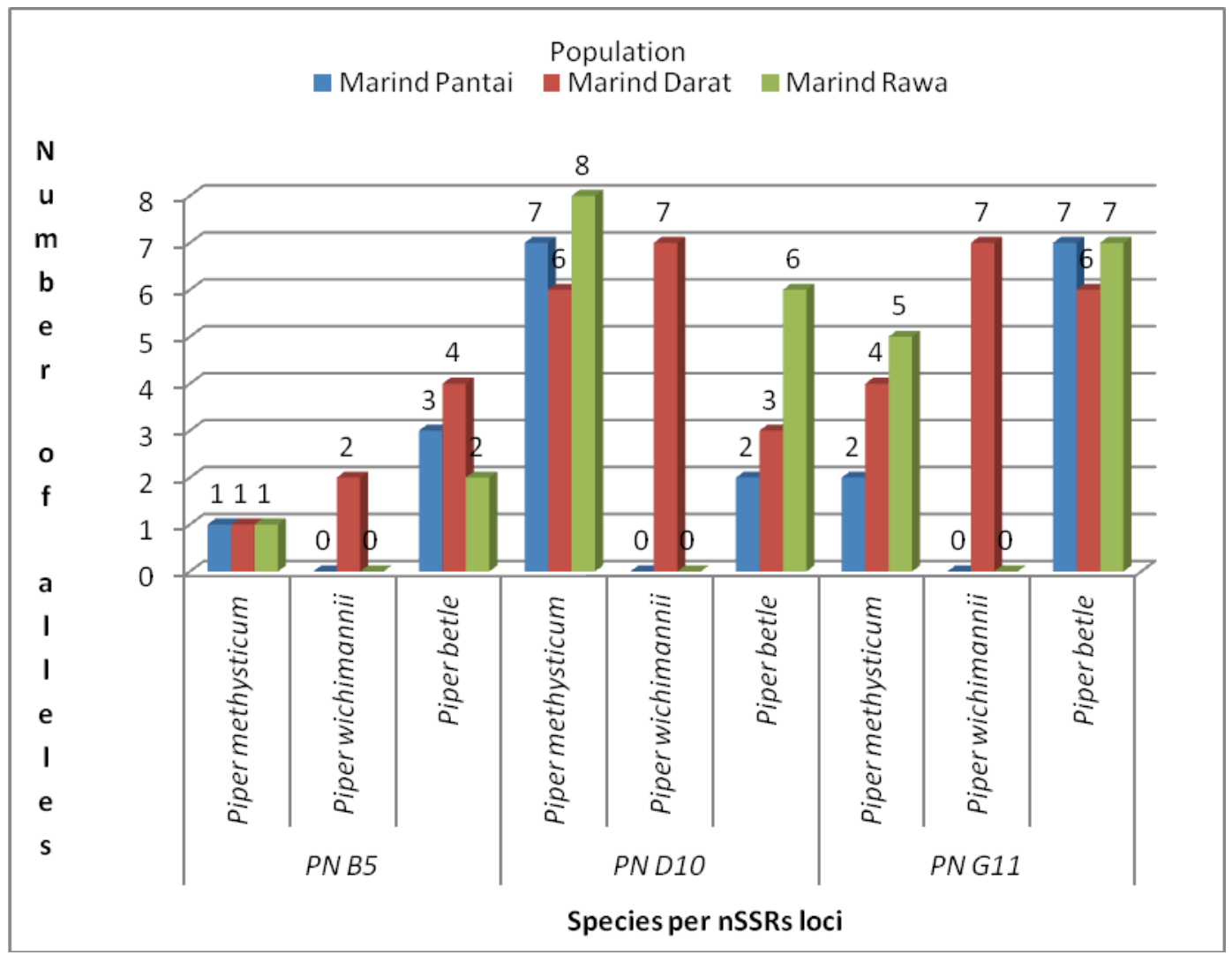

Figure 3-54. The number of fragments for each species per locus and population.

The distribution of the fragments of the different loci varies within the different species and populations (Figure 3-55). 


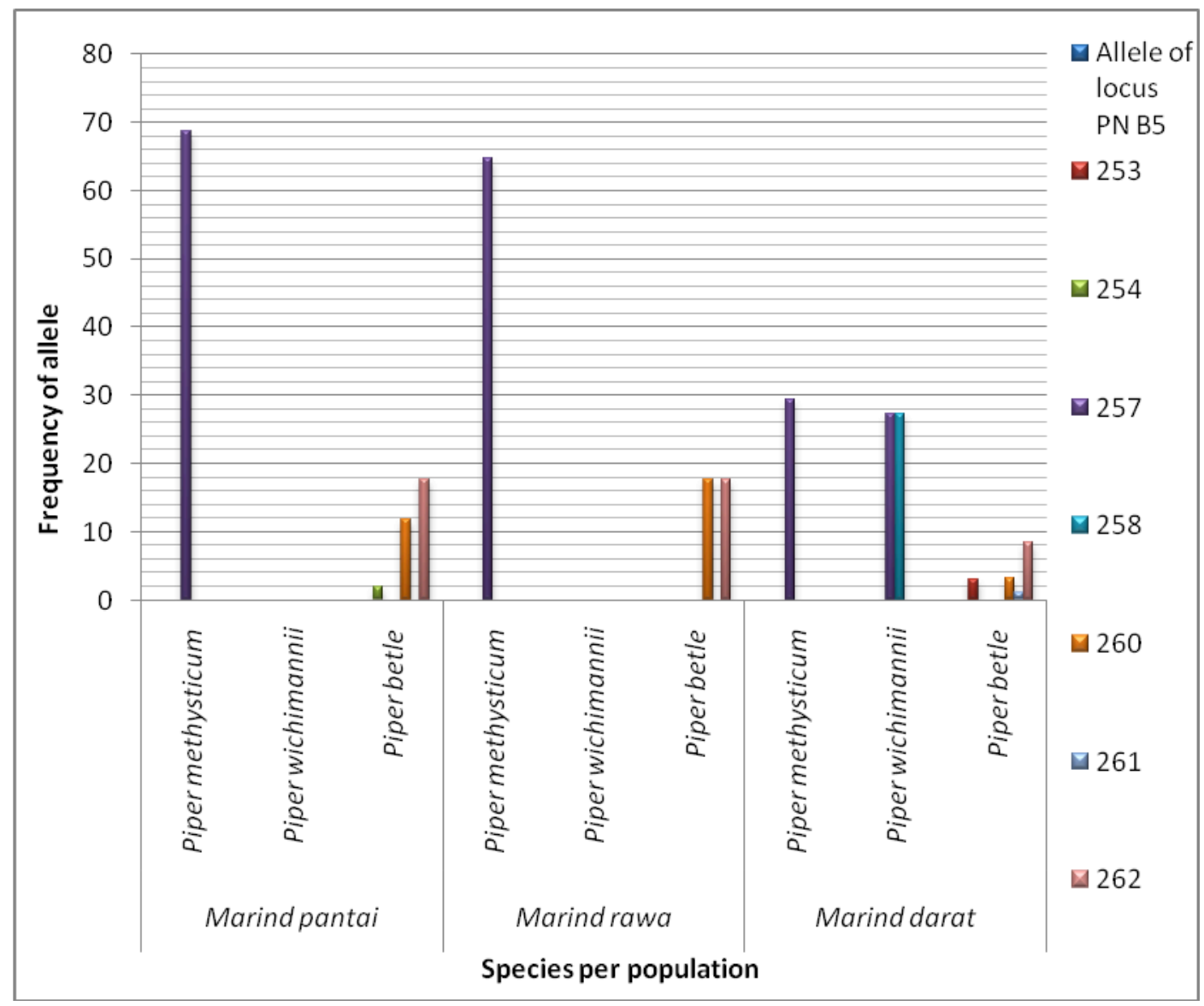

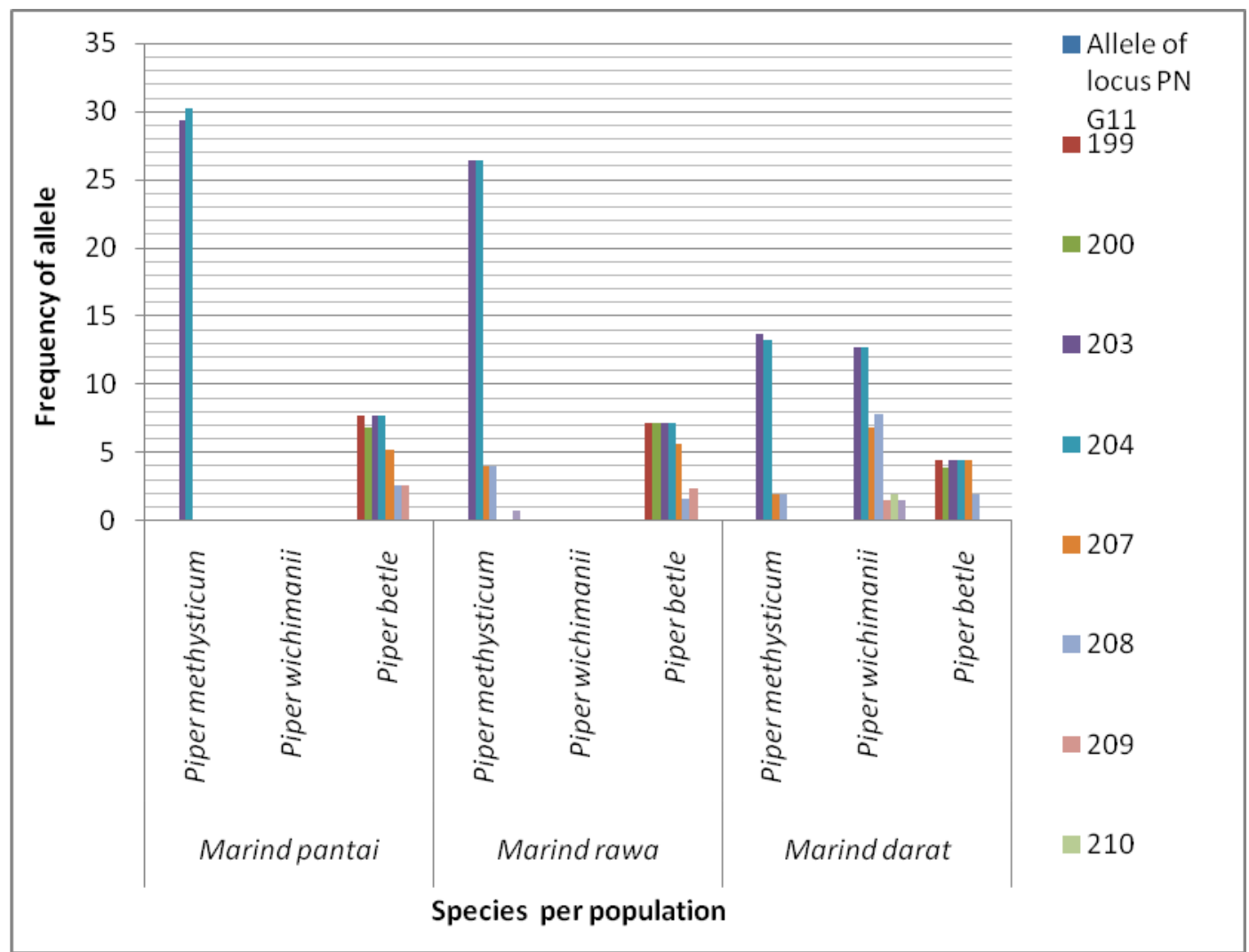




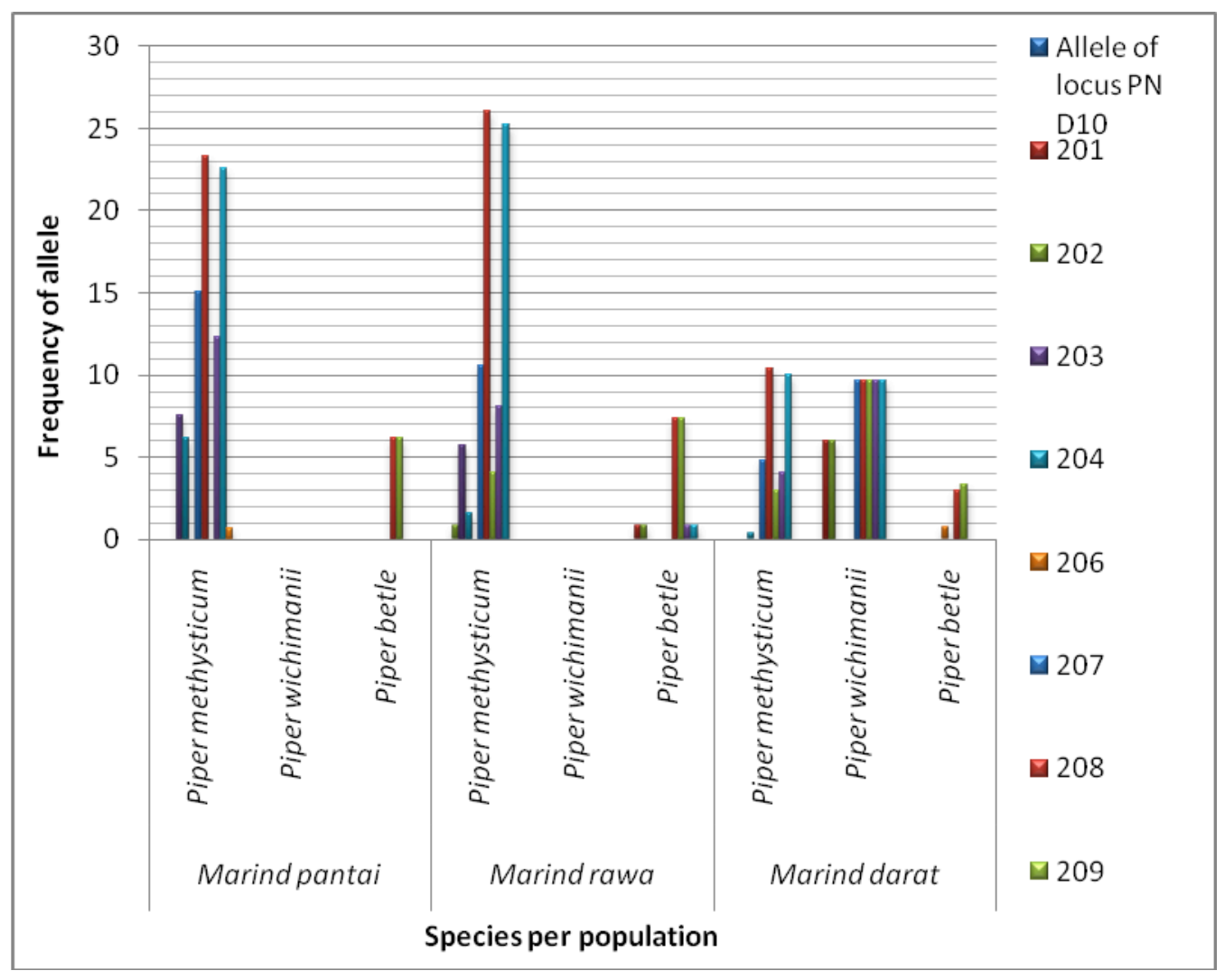

Figure 3-55. The fragment frequency within species per locus and population at 3 nSSRs loci.

In the case of the chloroplast DNA 4 primer pairs were tested (ccmp2, ccmp3, ccmp5 and ccmp9) first on a sample of 16 individuals; only the primer pairs of ccmp2 showed amplification products. Three different haplotypes were found with fragment sizes of $240 \mathrm{bp}, 241 \mathrm{bp}$ and $243 \mathrm{bp}$ (table 3-15 in appendix 7). Piper methysticum and Piper wichimannii are fixed to the haplotypes of $241 \mathrm{bp}$ and 240 bp (in the analysed populations), respectively and Piper betle showed also the haplotype of $241 \mathrm{bp}$ and and an additonal one of $243 \mathrm{bp}$ with a different distribution frequency in the analysed populations. (Figure 3-56 and Figure 3-57). 


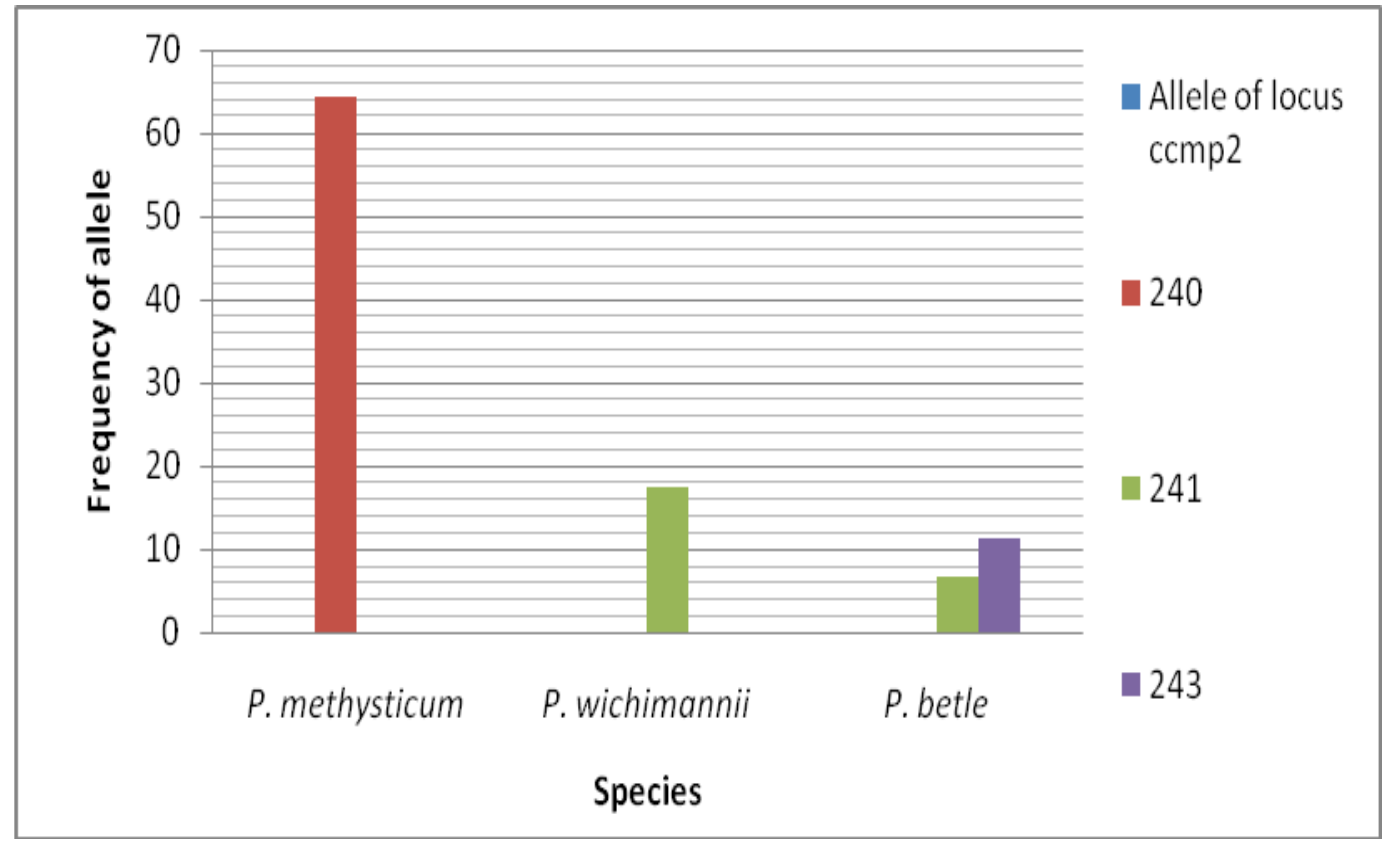

Figure 3-56. Distribution of the different haplotypes within the different species.

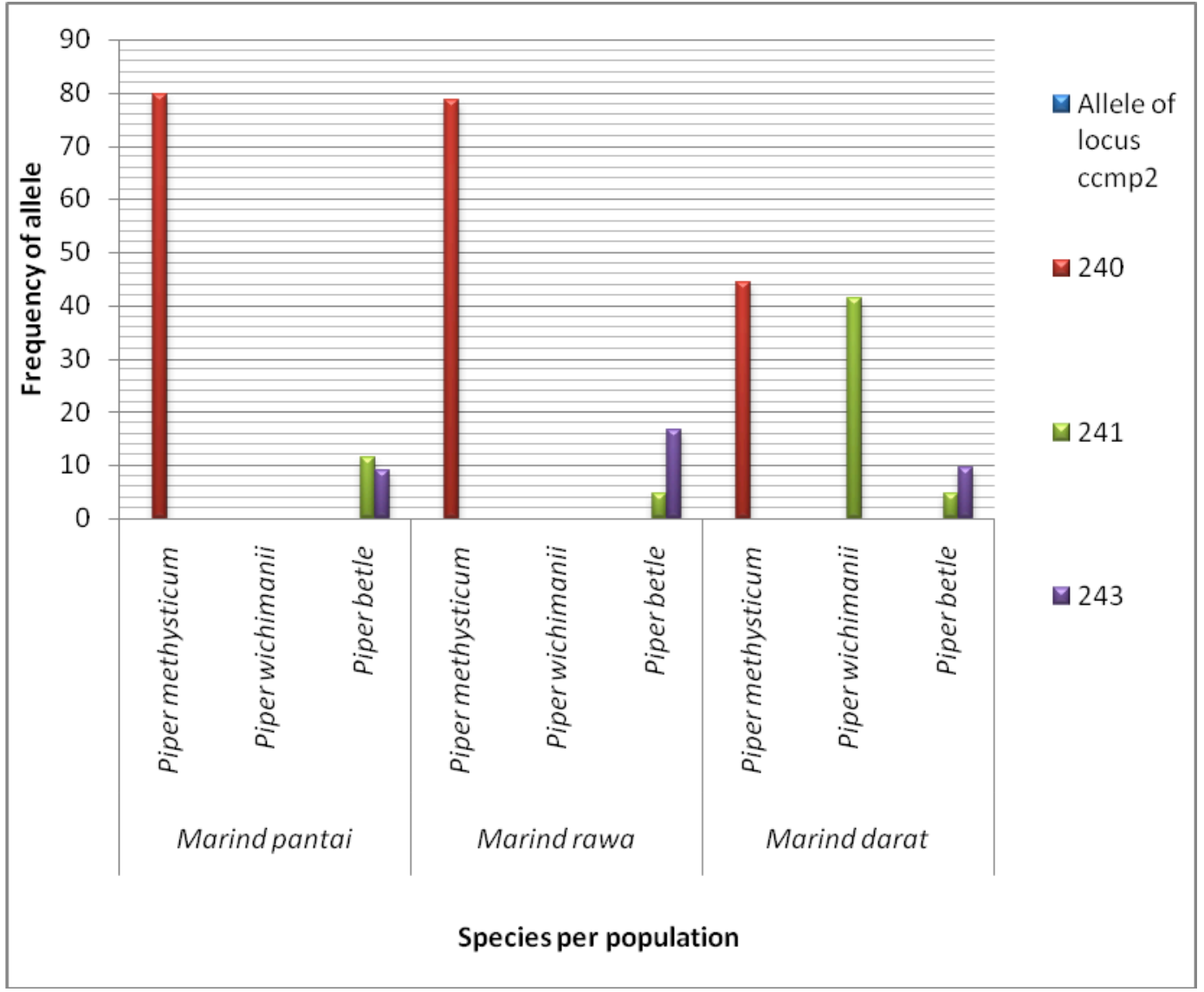

Figure 3-57. Distribution of haplotypes within species and populations. 


\section{3-3-3. Clonal diversity in Piper species}

\subsection{Number and frequency of clonal structures within Piper species}

The combination of the alleles produced by both chloroplast and nuclear microsatellites yielded a total of 50 clones for the three species. The highest number of clonal structures were found with 38 repetitions $(25,3 \%)$ of clone number C05 in Piper methysticum in Piper betle , 6 repetitions (4\%) of clone number $\mathrm{C} 15$ were found and 5 repetitions $(3,3 \%)$ of clone number $\mathrm{C} 31$ and clone number C33 in Piper wichimannii (Figure 3-58). 


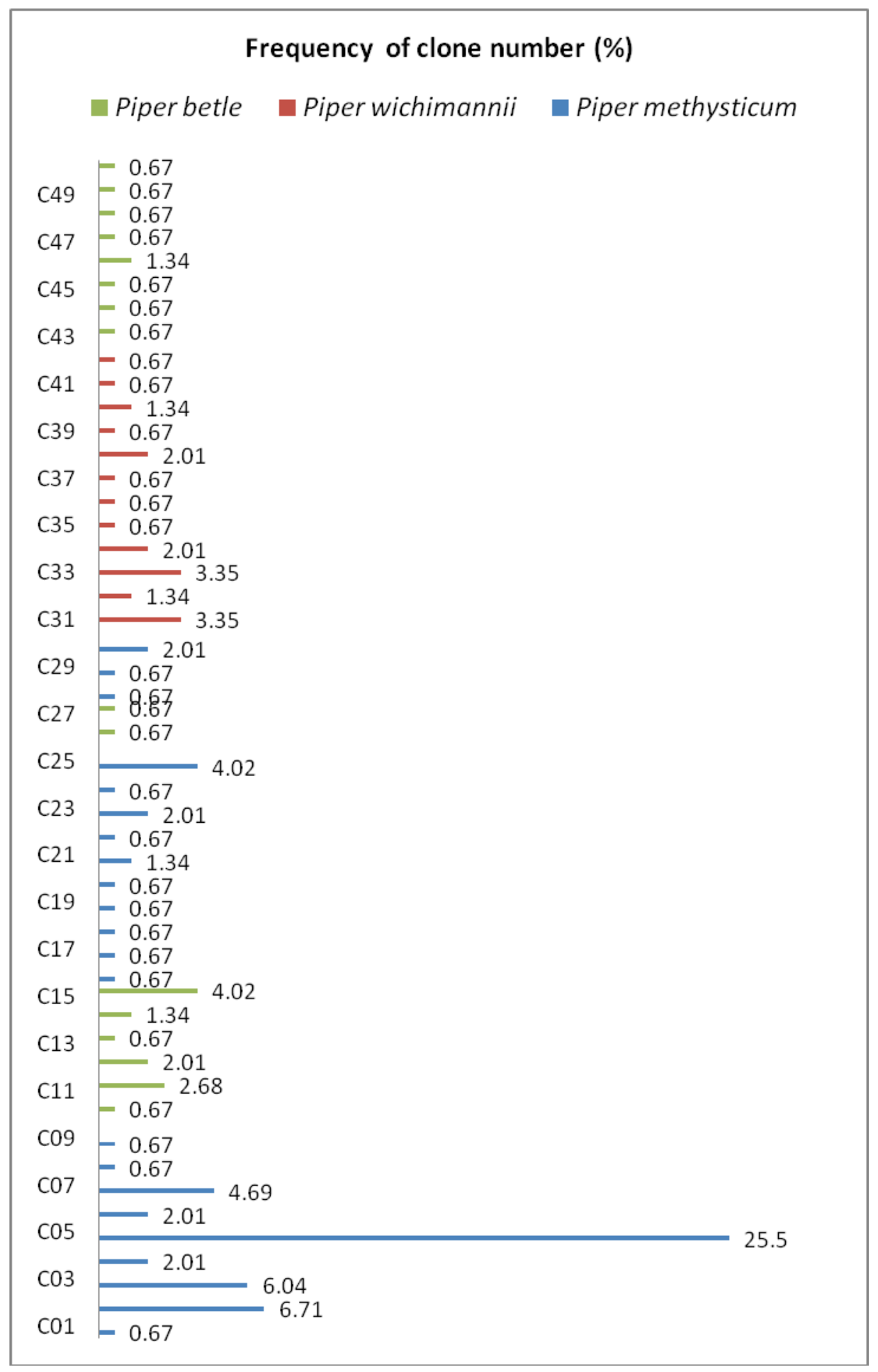

Figure 3-58. Number of clonal structures based the combination of nSSRs and cpSSRs from Piper methysticum, P. wichimannii and P. betle species in Marind Beach, Marind Land and Marind Swamp . 
Within the three different populations the clone number $\mathrm{C} 05$ showed the highest frequency in Piper methysticum; represented with 14 repetitions in Marind Swamp (Marind bob), 13 repetitions in Marind Land (Marind degh) and 11 repetitions in Marind Beach (Marind dufh) and in Piper betle with 5 repetitions in Marind Swamp (Marind bob) (table 3-16).

\subsection{Distribution of the clonal structures within different Piper species}

Using the total repetitions of the different clonal structures in Piper methysticum, Piper wichimannii, and Piper betle within the 3 analysed populations of Marind tribes 10 different ranks of variation could be identified and are summarized in Table 3-17. As mentioned above clone number $\mathrm{C} 05$ is mostly frequently represented and 29 clonal structures $(\mathrm{C} 01, \mathrm{C} 08, \mathrm{C} 09, \mathrm{C} 10, \mathrm{C} 13$, C16, C17, C18, C19, C20, C22, C24, C26, C27, C28, C29, C35, C36, C37, C39, C41, C42, C43, C44, C45, C47, C48, C49, and C50) appeared only once within the analyzed samples (table 3-17 and table 3-18 appendix 7).

Table 3-17. Ranking of clonal structures in Piper methysticum, P. wichimannii and $P$. betle based on nSSRs and cpSSRs (PN B5, PN D10, PN G11 and ccmp2) in the populations of Marind Beach, Marind Land and Marind Swamp.

\begin{tabular}{|l|c|l|}
\hline $\begin{array}{c}\text { Ran } \\
\text { king } \\
\text { No }\end{array}$ & $\begin{array}{c}\text { Total } \\
\text { repetition per } \\
\text { clone number }\end{array}$ & \multicolumn{1}{|c|}{ Clone number } \\
\hline 1 & 38 & $\mathrm{C} 05$ \\
\hline 2 & 10 & $\mathrm{C} 02$ \\
\hline 3 & 9 & $\mathrm{C} 03$ \\
\hline 4 & 7 & $\mathrm{C} 07$ \\
\hline 5 & 6 & $\mathrm{C} 15$ and C25 \\
\hline 6 & 5 & $\mathrm{C} 31$ and C33 \\
\hline 7 & 4 & $\mathrm{C} 11$ \\
\hline 8 & 3 & $\mathrm{C} 04, \mathrm{C} 06, \mathrm{C} 12, \mathrm{C} 23, \mathrm{C} 30, \mathrm{C} 34$, and C38 \\
\hline 9 & 2 & $\mathrm{C} 14, \mathrm{C} 21, \mathrm{C} 32, \mathrm{C} 40, \mathrm{C} 46$ \\
\hline 10 & 1 & $\mathrm{C} 01, \mathrm{C} 08, \mathrm{C} 09, \mathrm{C} 10, \mathrm{C} 13, \mathrm{C} 16, \mathrm{C} 17, \mathrm{C} 18, \mathrm{C} 19, \mathrm{C} 20$, \\
& & $\begin{array}{l}\mathrm{C} 22, \mathrm{C} 24, \mathrm{C} 26, \mathrm{C} 27, \mathrm{C} 28, \mathrm{C} 29, \mathrm{C} 35, \mathrm{C} 36, \mathrm{C} 37, \mathrm{C} 39, \\
\mathrm{C} 41, \mathrm{C} 42, \mathrm{C} 43, \mathrm{C} 44, \mathrm{C} 45, \mathrm{C} 47, \mathrm{C} 48, \mathrm{C} 49, \mathrm{C} 50\end{array}$ \\
\hline
\end{tabular}


The composition of the clonal structures is based on the combination of the different fragments sizes produced by the nSSrs and the different haplotypes produced by the cpDNA marker (Appendix 7,Table 3-16).

Table 3-18 (below) shows the different distributions of the clonal structures in Piper methysticum, Piper wichimannii and Piper betle within the 3 analysed populations. The most repititions were found in P.methysticum so the ranking classes 1-4 are exclusively formed by this species. The ranking classes 5 and 8 are formed by $P$. methysticum and $P$. betle whereas the ranking classes 6 and 7 are exclusively formed by $P$. wichimannii and $P$. betle, respectivley. And the ranking class 10 is represented by all three species. 
Table 3-16. Distribution of the clonal structures in Piper methysticum, Piper wichimannii, and Piper betle within the 3 analysed populations.

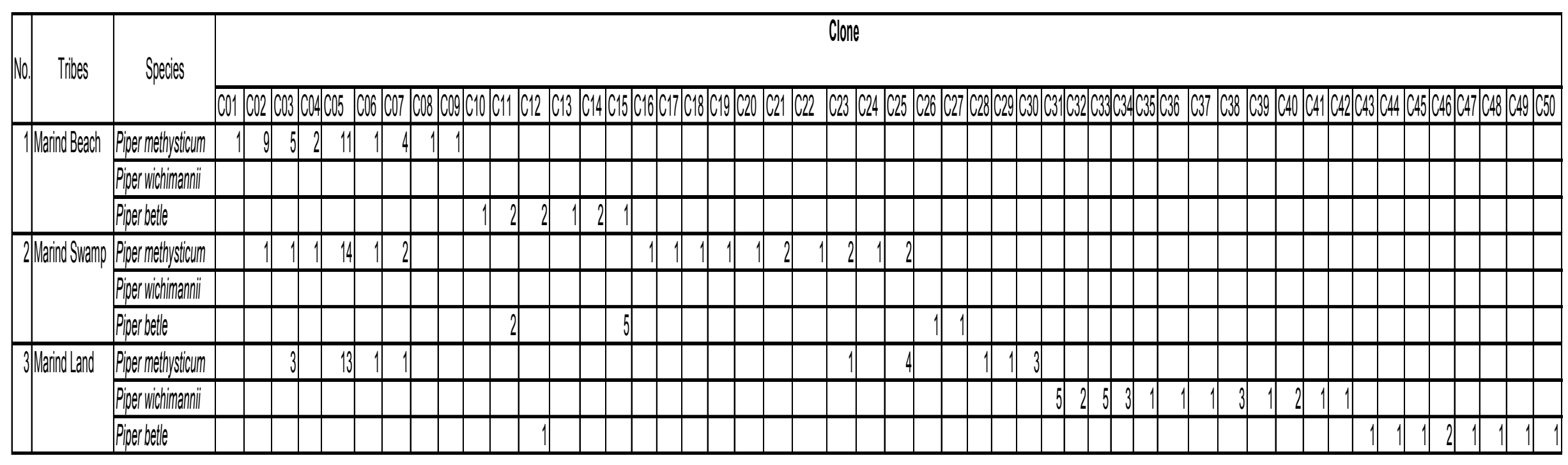




\section{3-4. Biogeography}

Data of survey and herbarium specimen collection in 2009 and 2010 in Herbarium Bogoriense (BO), Herbarium National Leiden, Herbarium National Australia Canbera (CANB), Herbarium Kew (England) is known, the distribution of Wati plant (Piper methyiticum Forst. dan Piper wichimannii) is below: (table 319 and 3-20 in appendix 8).

\section{3-4-1. Distribution of Wati plant in Marind tribe area}

The distribution of Piper methysticum species is in 3 group of Marind tribe area and Piper wichimannii species is only in Marind Land (Marind Darat / Marind degh) . People in Marind Beach (Marind Pantai / Marind duft) and Marind Swamp (Marind Rawa / Marind bob) know the cultivar with a certain name, but they do not cultivate all the cultivars in their garden (tabel 3-21).

Table 3-21. Distribution of Piper methysticum and Piper wichimannii in Marind tribe area.

\begin{tabular}{|l|c|c|c|}
\hline \multicolumn{1}{|c|}{ Species name and cultivar } & $\begin{array}{c}\text { Marind Beach } \\
\text { (Marind dufh) }\end{array}$ & $\begin{array}{c}\text { Marind Land } \\
\text { (Marind degh) }\end{array}$ & $\begin{array}{c}\text { Marind Swamp } \\
\text { (Marind bob) }\end{array}$ \\
\hline $\begin{array}{l}\text { Piper methysticum } \\
\text { cultivar Babid }\end{array}$ & $\sqrt{ }$ & $\sqrt{ }$ & $\sqrt{ }$ \\
\hline $\begin{array}{l}\text { Piper methysticum } \\
\text { cultivar Palima }\end{array}$ & $\sqrt{ }$ & $\sqrt{ }$ & $\sqrt{ }$ \\
\hline $\begin{array}{l}\text { Piper methysticum } \\
\text { cultivar Safurawe }\end{array}$ & $\sqrt{ }$ & $\sqrt{ }$ & $\sqrt{ }$ \\
\hline $\begin{array}{l}\text { Piper methysticum } \\
\text { cultivar Wati Kuning }\end{array}$ & $\sqrt{ }$ & $\sqrt{ }$ & $\sqrt{ }$ \\
\hline $\begin{array}{l}\text { Piper methysticum } \\
\text { cultivar Munana }\end{array}$ & $\sqrt{ }$ & $\sqrt{ }$ & - \\
\hline Piper wichimanii $*$ & - & &
\end{tabular}

* kultivar Marub (Kameubun, 2003). 


\section{3-4-2. Distribution of Wati plant in Papua}

Based on herbarium specimen data, Wati plant in Papua can be found in the footpath of Komopa village near Enarotali, Tembagapura in Mimika regency, Alaku and Merauke village in Merauke regency, and Wurigelebur village in Kelila district in Wamena regency (but now 2012, Wurigelebur village in Kelila district in Wamena regency was changes administrative region to become Eragayam district, Mamberamo Tengah regency) (figure 3-59).

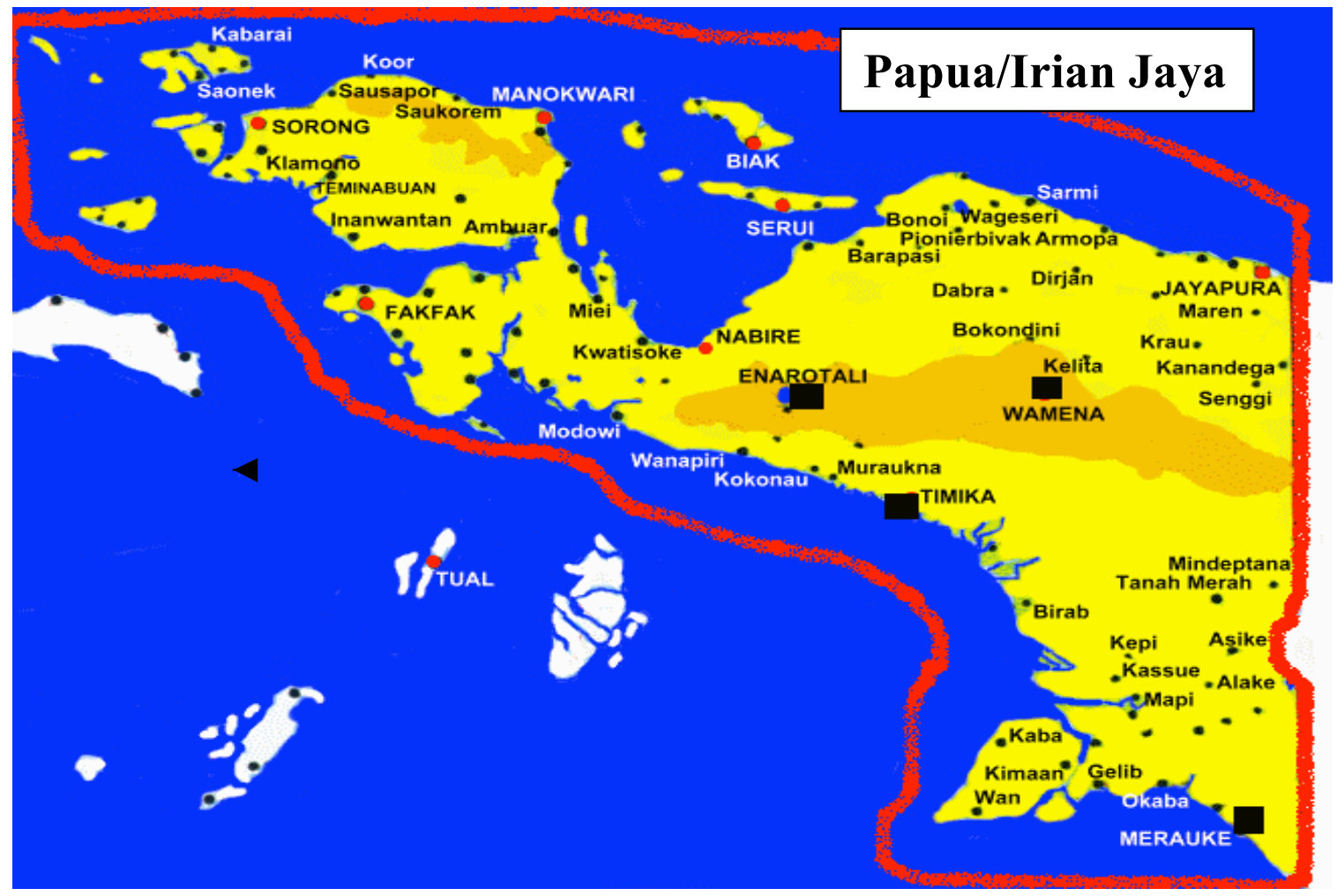

Figure 3-59. Distribution of Wati plant in Papua/ Irian Jaya based on herbarium specimen data : $=$ the location of Wati plant. 


\section{3-4-3. Distribution of Wati plant in Indonesia}

Wati plant consisting of the natural species of Piper wichimannii and Piper methysticum is only found in Papua but not in another Indonesian region (figure 3-60).

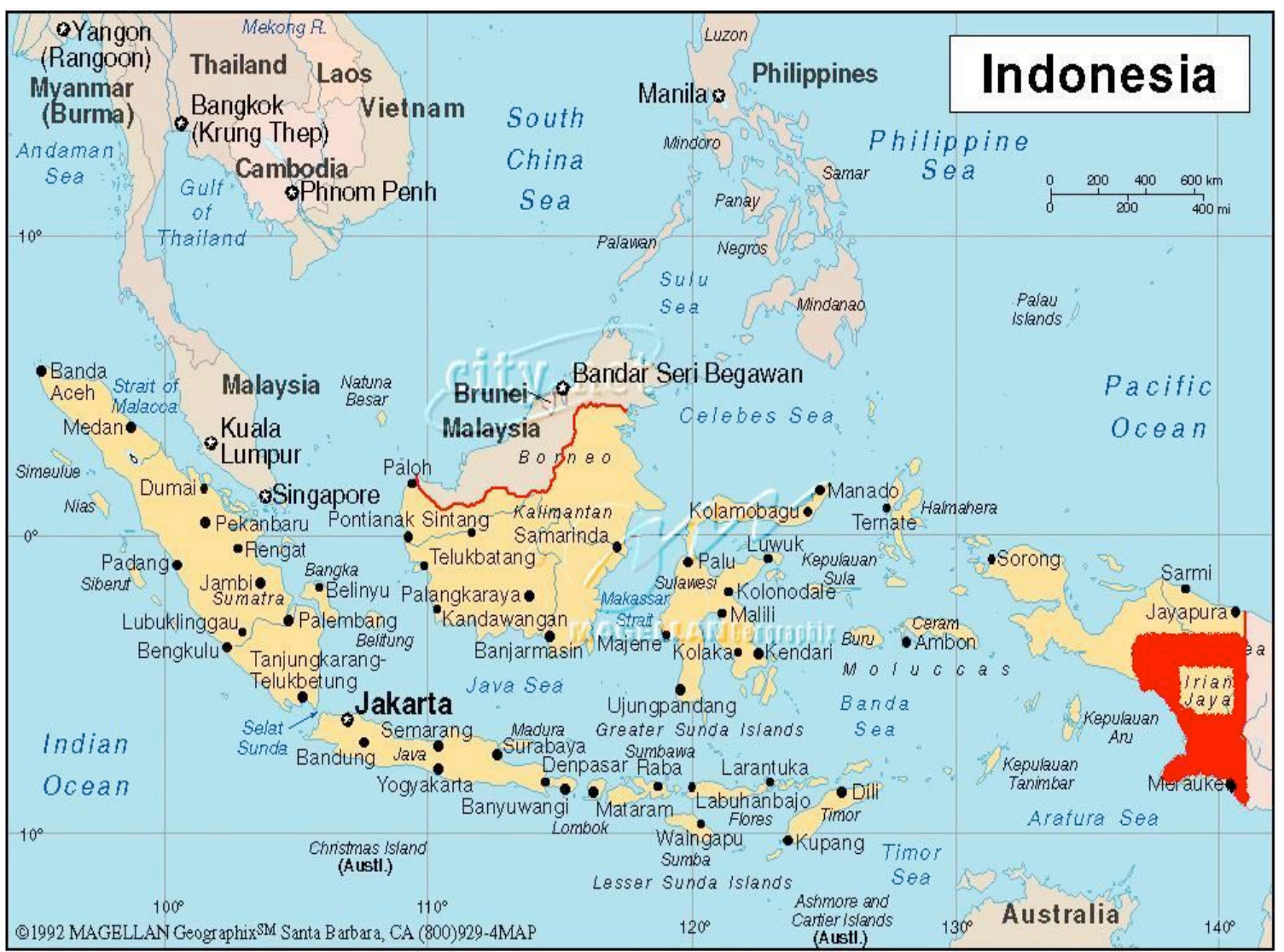

Figure 3-60. Distribution of Wati plant in Indonesia based on herbarium specimen data. $\square=$ location of Wati plant founded. 


\section{3-4-4. Distribution of Wati plant in the world}

The distribution of the Wati plant (Piper methysticum and Piper wichimannii) is limited to some countries in the world, namely: Indonesia, Papua New Guinea (PNG), Samoa, USA, New Zealand, Fiji, Vanuatu, and French Polynesia (table 3-19 and 3-20, appendix 8 and (figure 3-61).

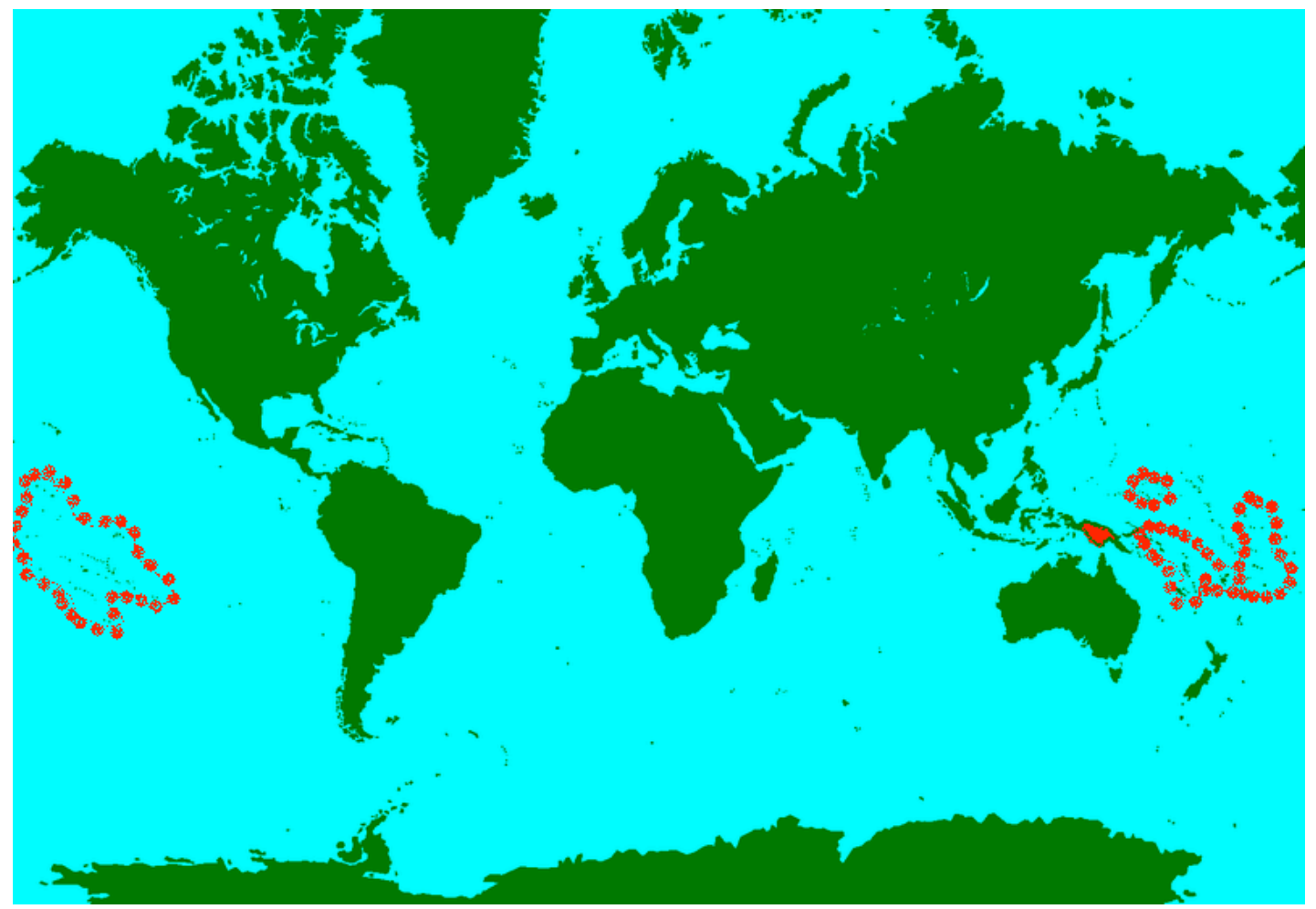

Figure 3-61. Ditribution of Wati plant (Piper methysticum and Piper wichimannii) in the world (see red colour).

The monitoring of Wati plant distribution during 7 years 2003 to 2010 has similar results reported by Kameubun (2003). Wati plant is found in Oceania area only. Barrau (1972), said that Malayo-Oceania spanned from Malaysia and Philippines to the Melanesia continental island. Oceania region consist of Melanesia, Micronesia, and Polynesia race (figure 3-62). 


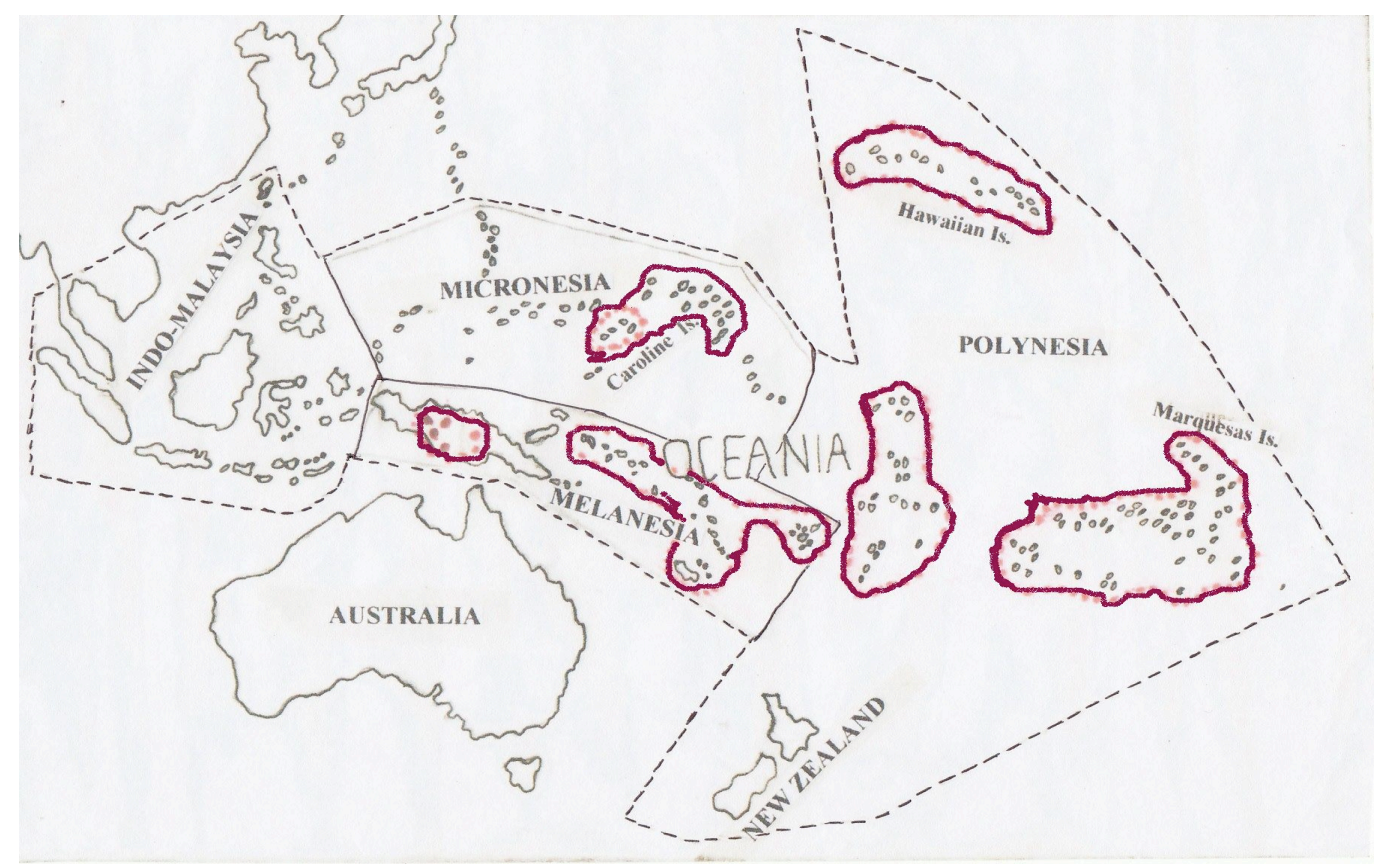

Figure 3-62. Distribution of Wati plant in Malayo-Oceania region. Source: Kameubun, 2003.

The Wati plant which is found in the Micronesia race area is in the Nanpil river in Ponape (Caroline archipelago). In the Polynesia race, it is found in the Papenoo and Orofena valley, and Puunui, Hitiaa district, Tahiti, (Society Island); Toovii, Nuku Hiva (Marquesas archipelago); Lanuto Lake, Upolu (Samoa Island); and in the Hawaiian archipelago; Honolulu; Pahoa; Waiahole, Oahu; Halawa vellay, Molokai; Lyon Arboretum, Oahu; Hanakapiai, Kauai; Mapulehu vellay, Molokai; the Koolau mountains, Oahu; Kaueleau, Puna district; and in Lakepa, Niue, New Zealand.

The distribution of the Wati plant in the Melanesia race is found in New Guinea island and some regions in the pacific archipelago. New Guinea of the east is an area of Papua New Guinea and that of the west is an area of the Indonesian country. in Papua New Guinea, the Wati plant is found in Herbart Hoover Lake, Bosset; Kaiser Wilhelm island; New Pommern, Bei Massawa; Nova Guinea Neerlandica Meridionalis, Haku; in the Purari River, Gulf. The distribution in the pacific archipelago is found in Fiji, Vanuatu. And based on some report on the Wati plant (Piper methysticum), this plant is located in the Salomon archipelago. 


\section{Chapter 4. DISSCUSION}

\section{4-1. The particular importance of Kava (Piper methysticum Forst.) in traditional ceremonies}

Clan Ndiken, Samkakai and Kaize hold a right on Kava planting which derives from the division of the totem in the Marind tribe. A totem is a superstitious belief on a relationship between a group of people - sometimes also an individual - and animals or plants or material objects (Van Baal, 1987). A totem is a material object in the shape of an animal or plant which is respected in the tribal society because of the superstitious belief that such an object has a strong and intimate relationship with the tribe (Van Baal, 1987).

Totems are lend down to every clan (family) in the Marind tribe according to dema. Dema is a form of animistic beliefs. According to them an ancient spirit may influence the nature. The Marind tribe believes that dema materializes as the universe and in humans. Every dema has a special totem which is suspected to be related to the clan. Each clan takes care of their own totem. Kava is the totem of Fratri Aramembrek, a large bird that lived in the past (Warip, 1996). Apomfires (2002) stated that every clan of the Jae tribe (a branch of the Marind Tribe) has totems consisting of animals and plants. Usually the totems of the Jae tribe are sacrificed yet allowed to be touched. Some clans, however, forbid to touch the totems. For example, the totem of the Keijai clan is a cassowary. Although the bird is deified it is allowed to be touched and eaten by the Keijai clan. The Kewamijai clan uses Sago as a totem. However, Sago is still eaten by the clan members. It is a taboo to divulge the tales relating to the foundation of the clan outside the own clan.

\section{4-2. The spreading of the classification, cultivation and use in all cultivars}

Piper wichimannii and Piper mathysticum with their five cultivars have 70 specific names in 32 villages in Merauke. This is because one Kava cultivar could have more than two local names in the community of three Marind tribes. The 
difference in name is due to variations in dialect. The identification and classification of the plant inside the three groups of Marind people are based on plant morphology and the quality of the drink that can be produced from the Kava plant. This is similar to the customs of the locals in Fiji, Vanuatu, Samoa and the Solomon Islands (Davis and J.F Brown, 1999: Lebot et al.,1997 : Nelson, 2011).

The traditional naming system for Kava in the three groups of Marind people is similar to the traditional naming system in the South Pacific. They use a general name as well as a specific name for the cultivars. Kava is the name for Piper methysticum and Piper wichimannii used in the South Pacific. The Marind people uses the name Wati. For the sake of consistency reason, the name Kava will be used in the whole section. However, the traditional naming system for Kava is different in the Marind region and the South Pacific.

The Marind tribe use specific names of the Wati plant that they have inherited from their parents (ancestors). The traditional naming system of the Marind tribe is binomial. In some ways this is similar to the scientific naming system in which a first name (genus) is followed by a second name to indicate the name of the species (Rideng , 1989; Sharma, 2009). The first word refers to the general name and the second word is the specific name, e.g. Wati Palima refers to the cultivar of Wati (Kava, general name) which is locally called Palima (cultivar name, red stem and long branches). In contrast, the people in South Pacific i.e. in Fiji use the specific words such as vula (white) or loa (black) for green and purple cultivars, respectively, or kasa (branch), balavu (long) and leka (short). Examples for names in the Fiji system would be Loa kasa leka (purple stem, short branches) and Vula kasa balavu (green stem, long branches). In Tonga the naming system is similar to the system in Fiji. They refer to the stem colour - kula (black), hina (white) -, the branch length - akau (long), leka (short) - and whether the leaves are covered by trichoma. An example would be hina akau (green stem, long branches) (Davis and Brown, 1999). 


\section{Cultivation}

In Merauke, Papua New Guinea (PNG), Fiji, Vanuatu, Tonga, Solomon Islands, Hawaii and other islands in the South Pacific, Kava or Wati is planted by cutting stem or bud. However, the cultivation technique is different.

The cultivation technique of Kava among the Marind Darat (land) people and the Marind Pantai (coast) people is similar but it is different to that of the Marind Rawa (mangrove) people. The cultivation technique of the Marind people in Merauke is different from that in Vanuatu (Diagram 4.1; picture by L. Lindstrom from book written by Lebot, et al., 1997).

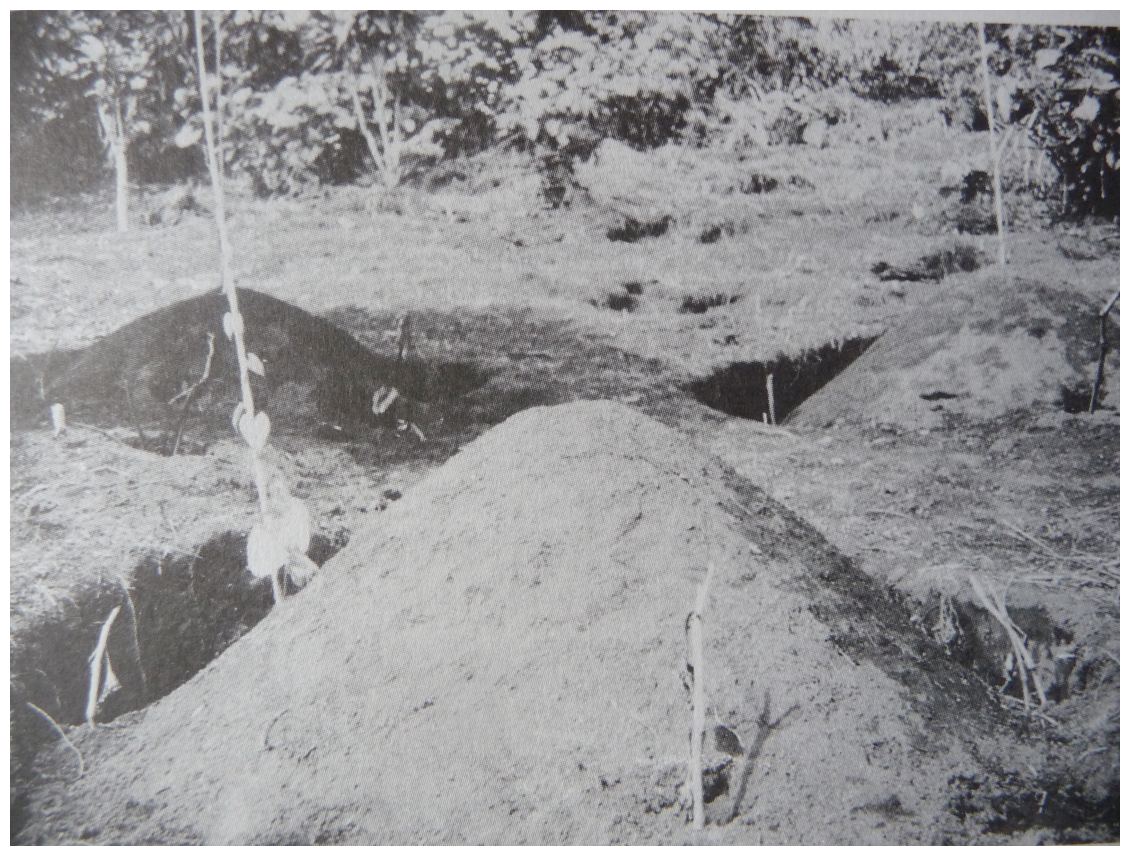

Figure 4-1 Cultivation technique in Vanuatu (Diagram 4.1; picture by L. Lindstrom from book written by Lebot, et al 1997)

Protection measures for recently planted Kava from direct sun irradiation, wind and rain is the same in the Marind people and South Pacific natives. According to Lebot, et al., (1997) the bud of a new plant of Kava has to be protected because direct sun irradiation increases the rate of evapotranspiration.

The $50 \mathrm{~cm}$ spacing of Kava plants practiced by the people in all three ethnic Marind groups in Merauke showed to be an ideal handling method because with this way the plants can grow into dense clumps that would require 
considerably more space. According to Polunin (1994), the provision of adequate space could avoid competition in plant growth and development. In particular it allows the leaves to absorb light for photosynthesis. The main organ for photosynthesis is a broad leaf. This factor is important because Kava is categorized as a plant with broad leaves (Fahn, 1992).

The protection technique for Kava used by the Marind people is slightly different to that used by the indigenous population of Samoa, Pohnpei, Hawaii and Tongatapu (Tonga). They set a side a plantation embedded in a agroforestry system for example Kava is planted together with e.g. banana, papaya and coconut. Thus the Kava plant can be protected from direct sun irradiation and strong winds (Nelson, 2011). The Marind community developed a similar agroforestry system in which Kava is also planted together with other crop plants in the same plantation. But these crops differ from those planted in the garden with kava plantation described by Nelson. Lebot et al (1997) reported that in Melanesia Kava thrives in multiple cropping plantations in a forest. Herein Kava is protected by larger surrounding plants such as banana and sweet potato. Kava is suitable for agriculture in the Pacific region because of its flexible cultivation requirements and it also thrives in cooler places. Besides this agroforestry system for protection, the Marind people also use coconut (Cocos nucifera) or sago leaves (Metroxylon sago) having a wax coating. It is the coating that cures them for the water to be absorbed. Thus the leaves are very helpful to reduce the amount of rainwater falling on the Kava plants in the plantation. However, when the leaves are left for a long time they will necessarily decay. Under such conditions they are usually used by insects as a nest. The presence of insects can become a serious threat for Wati plants. In order to prevent such an insect infestation of Kava, the coconut and sago leaves have to be changed on a regular basis.

\section{The role of weeds and harmful insects in the Kava plant cultivation}

The Marind tribal community is aware that Kava plantation should be kept clean of other plants considered as pests (weeds). The presence of weeds can 
cause damages to Kava (weeds as pest infestation host). Pest infestation usually interferes with the growth of Kava in the Merauke region. Nelson (2011) stated that Kava is susceptible to many pests and plant pathogens. Diseases that can affect Kava and cause weakness or even death of the Kava resulting in a dieback of the Kava plantation (the most common causes are viral infections caused by CMV (Cucumber Mosaic Cucumovirus), root rot (caused by the pseudofungus Pythium splendens), hollow (spots occurring on the leaves and stems are caused by the fungus (Phoma sp.), root nodes / root knots (a lumping of the root occurs caused by nematodes such as Meloidogyne sp.) and rotting of stem cuttings (caused by the fungus Fusarium sp.). Davis and Brown (1999) reported that bacteria of the genus Erwinia is a pest transferred by some insects and invertebrates (Elytroteinus subtruncatus Fairm., Tetranyc urticae Koch., Rhizoglyphus echinopus (Fumouze and Robin), Aphis gossypii, Planococcus sp., Parasaissetia Neitrer nigra, Aspidiotus destructor Sign., Spodoptera sp., Achatina fulica Bowditch). Among vertebrates are to be mentioned various mice species. Also the effect of abiotic factors such as sea water with a high salt content is of importance. Onwueme (2000) stated that the most serious pests attacking Kava are beetles that bore holes in the stems and leaves. To eradicate these pests insecticides are used. Davis et al. (2005) reported first the case of a Kava dieback in Fiji in the year 1932. The same disease happened in Tonga, Samoa and Vanuatu, as reported by Davis et al. (2005), Davis and Brown (1999). As the result of such a dieback disease the production of Kava dropped by a $40 \%$ in Fiji in 2005 (Davis et al. 2005).

Onwueme (2000) stated that a clean Kawa garden could help in controlling stem rot diseases in the plants caused by CMV infection which is transmitted by Rhopalosiphum sp.. This leads to the symptom of the wilting of new bud. According to Xuan et. Al., (2003): Xuan et al., (2005) Kava can inhibit the growth of five fungi species such as Fusarium solani, Pyricularia grisea, Rhizopus stolonifer, Taphrina deformans and Thanatephorus cucumeris. Through the knowledge of those fungi which can be inhibited by Kava and by determining the cause of the diseases that attack Kava the fungal infection of the Kava plants can be left to be treated by itself. 
Nguyen et al. (2002) proposed that the Kava plant can be used for controlling weeds in a paddy. Thus Kava plants can also be used to reduce the herbicide use. Xuan et al., (2003) stated likewise that Kava can be used as a natural herbicide and as a potential pathogen control to reduce herbicides and pesticides in agriculture. Xuan et al. (2005) furthermore stated that Kava is a plant with strong allelopathic properties. Allelopathic chemicals are released from the plants into the environment by exudation from the roots, stems and leaves, by evaporation or by decomposition of plant material. The utilization of allelopathy has good prospects in weed management and also in the control of insect pests and diseases in plants. Kava can be used in addition to other crops such as alfalfa (Mediago sativa L.), asparagus (Asparagus officinalis L.), buckwheat (Fagopyrum esculentum Moench), hairy vetch (Vicia vilosa L.), red kumangi (Trifolium pratense L.), taro (Colocasia esculenta Scott) and hairy beans (Mucuna pruriens).

\section{The importance of soil characteristics}

Most of the soil in the Merauke region is muddy. When the air temperature is too hot the mud is going to dry. Too much rain water would cause inundations in low-lying areas and thus contribute to the formation of lowland swamps.

Mud dominates the area populated by the Marind Rawa (Marind bob) and Marind Pantai (Marind dufh) groups, while sandy loam soil prevails in deeper areas populated by the Marind Darat (Marind degh). Most of the Marind Pantai settlements are close to the coast with sand beaches. However, they cultivate Kava in muddy areas far from the coast, to avoid the salt water. The Marind Darat (Marind degh) opened plantations on muddy soil as well as on sandy soil. While in the Marind Rawa (Marind bob) region mud prevails and only a small portion is sandy soil - which is used for their homes (Marind Swamp), and the Kava plantations are in muddy areas.

The Merauke region is predominantly upland. The land form is tectonically (structurally) categorized as old sand shoals. The soil in the land form of sedimentary rocks is acidic, containing typic Eutrudepts, oxic Dystrudepts, typic Plinthudults, and typic Hapludults. Meanwhile, the land shows old sand bars 
at the beaches formed by marine sediments consisting of typic Udipsamments and typic Quartzipsamments. The analysis of the minerals yielded that the sedimentary rocks are dominated by cloudy quartz, and there are smaller part of of clear quartz and iron and a very low content of nutrients. To improve the quality and potential of dryland crops complete NPK fertilizing, agricultural liming and organic matter are required. The soil quality and its potential for agriculture are determined by the lithology, climate and topography (shape) of the region (Djaenudin and Hendrisman 2008).

The average soil $\mathrm{pH}$ in Merauke is 4.20 to 7.20 (Al-Jabri and Tafakresnanto 2008), respectively 4.20 - 7.70 (Djaenudin and Hendrisman 2008).

According to the general knowledge, good condition for the growing medium of Kava in all three ethnic Marind groups is soil that is not too wet, not dry, has lots of topsoil and low salinity. Lebot et al. (1997) and Nelson (2011) reported that, Kava grows well in loose soil with good drainage and aeration and in a soil or medium that is rich in organic matter (topsoil / nutrients), with a $\mathrm{pH}$ of 5.5 to 6.5. Highest growth of Kava was found on the silica-clay soil. The ideal planting site is next to the river, on the edge of the forest on the slopes or in rainexposed sites, preferentiallly protected from the wind.

The soil $\mathrm{pH}$ in the Merauke region ranges from 4.20 to 7.70 . It can't be determined easily which area of these three groups suits best for the growth of Kava because the growth depends also on the treatment. Polunin (1994) stated that the availability of water is one of the most important factors for the plant. An excess or a shortage of water can bias considerably their life processes.

When the Marind people say that Kava should be fed and have a drink they mean that the plants need to be given fertilizer and water. Local knowledge to protect the plants by utilizing natural resources is the use of the grass Alangalang (Imperata cylindrica) and several other grass species functioning as an organic fertilizer. Thus the dry grasses provide a dual function as protection and as organic fertilizer or "food" for the survival of Kava. Suriadikarta and Simanungkalit (2006) mention that the material / organic fertilizers are very useful for the improvement of agricultural production both in quality and quantity, thus reducing environmental pollution and improving the quality of the land in a 
sustainable manner. Sources of organic matter can be the compost, green manure, farmyard manure, crop residues (straw, stover, corn cobs, sugar cane bagasse and coconut fiber), animal waste, industrial waste containing agricultural materials, and municipal waste. The basic ingredients of organic fertilizers derived from crop residues use to be low in harmful substances. However, the use of manure, industrial waste and municipal waste as a raw material compost / organic fertilizer is quite alarming because many contain hazardous materials such as heavy metals and organic acids that can pollute the environment. According to Onwueme (2000), in addition to the actual compost manure, chemical fertilizer NPK (12-12$20)$ or urea $(46 \% \mathrm{~N}$ content) can be given to the Kava plants. Hartatik and Setyorini (2008) stated that precise nutrient management through organic fertilizer and organic matter management are required in order to meet the nutrient requirements of rice crops in organic farming systems. The use of an organic fertilizer dose of $10-15 \mathrm{t} /$ ha in combination with straw and rice husk is able to meet the nutrient requirements of rice crops in organic farming systems. Thus the traditional knowledge of the indigenous Marind tribe in using grasses as protector and fertilizer is valuable, as is corroborated in the field of agriculture.

\section{Optimum time for harvesting}

The ideal harvest period, according to the three ethnic Marind groups, is 1.5 - 2 years. If the harvest is too early in the life period of the plant it will not a strong or quick a production strong or quick enough. However, after three years of age the stem will be too hard to chew. The harvesting time differs from that in Fiji, Vanuatu, Tonga or Samoa which is about 3-4 years (Lebot et al. 1997), or 3-5 years (Davis and Brown 1999). The highest kavalactone content is found after a median age of 18 months (Lebot and Levesque 1996). Whiton et al., (2003) reported the concentrations of different kavalactones can be found in Kava plant root tissues at the age of 5 and 8 years. At the root bark the content is higher compared to parenchymal and sklerenchymal tissue. At a minimum age of 8 years the kavalactone concentration in the root bark is higher than at the age of 5 years. 
Therefore, if a high kavalactone concentration is desired Kava should be harvested at an older age of \pm 8 years.

\section{The use of Kava in other ethnics groups}

Davis and Brown (1999) reported that the Kava plant is important in traditional ceremonies and as a cash crop in Fiji, the Solomon Islands, Vanuatu, Samoa, and Micronesia as a part of Ponape in the North Pacific. According to Lebot et al. (1997), Davis and Brown (1999), and Nelson (2011), Kava has been used commercially in factories. It became a popular intoxicant, drug and supplement. Nelson (2011) said that in Hawaii Kava is imported from the islands of Fiji and Tonga. Several countries in the Pacific islands, however, do not import Kava, as they can grow enough this plant for their own consumption. Similarly, the Marind tribe people grow it only for their own consumption.

People in all three Marind groups in Merauke utilize the leaves, stems and roots of the plants as medicine while the stem and roots are used as raw materials for beverages and also medicine. Heyne (1987) stated that traditionally in the Marind tribe Kava is only drunk by adult males. However, there has been a change (acculturation) in the application of traditional rules among the Marind tribes. Kava can now be drunk also by women. Recently other people are free to grow and provide information about the plant. This is not in accordance with the traditional rules of the Marind tribes. In Fiji Kava is usually consumed by native men and women as well as the Indian population. Aboriginals in Australia do not a tradition in Kava consumption but since the beginning of the 1980s they were introduced to drink Kava (Davis and Brown 1999).

Both parts of the Wati plant (roots and stems) are used as intoxicants. When processed to a drink it will make people drunk. In experiments with plant extracts of Palima cultivars (Piper methysticum cv. Palima) from Merauke on the length of sleep time in mice (Mus musculus) a differential effect was found depending on which parts of the plant (leaves, stems or roots) are given and on which dosage. Leaves will only cause hangover-like effects. Stems and roots cause hangover-like effects, sleep, paralysis and death. Roots provide the same 
effect as rods, stronger and faster than leaves or stems. Increase in dosage may trigger a faster reaction (Corry, 2008). Agusta and Yuliasri (2007) reported that the content of the compound dihydromethysticin in the stems of Kava is much higher than in the leaves. Therefore, there is much stronger narcotic effects result from the use of stems than of leaves. Lebot et al. (1999) reported that the overall content of kavalactones in all cultivars in Hawaii decreases from the root over the stem to the leaves. Thus the traditional experience-based knowledge of indigenous Marind tribes on the reaction strength of the respective plant parts and the plant age is corroborated.

\section{Medical use}

Effects of drinking Kava, may include numbness, the body becomes heavier and can not stand or sit, eyes close and the consumer falls asleep. If consumers trespass the limits of drinking Kava the person may become inert and non-productive Anonymous (1972). Heyne (1987) described that after drinking the beverage the consumer will find a comfortable place on the sand, find it difficult to think and feel sleepy. After resting for a few hours people get back to normal again. According to Hansel and Woelk (1994), drinking Kava produces friendliness and a feeling of being relaxed and sleepy despite increased social interaction, and vomiting after higher doses. After ingestion the sensation of pleasure / relaxation will appear without aggression, fully conscious, later sleepiness dominates. Local anesthetic effects on the tongue and the palate result in a loss of appetite and eventually weight loss. Kavapyrones have been found in Kava and are known to have psychotropic properties. The effect of psychotropic consists generally in relaxation and euphoria depending on the doses taken, whereas higher doses will cause drowsiness and relaxation of skeletal muscles. This relaxation and cheering up is due to the activation of mesolimbic dopaminergic neurons. Drowsiness is explained by changes in neuronal 5hydroxy-tryptamine (5-HT, serotonin) activity (Baum et al. 1998). Anesthetic effects on the palate and the tongue may be caused by an increased contribution of yangonin which is a dopamine antagonist produced at low doses. If the 
concentration is high it cannot provide a sense of joy (the usual drug effect) in consumers.

When the chemical content of Kava was known, the plant was processed to herbal supplements in capsule form, liquid extracts, powder and tea (Connors, 2009) as well as modern dosage forms such as tablets, capsules and liquids. The drug is manufactured for sleeping pills, for the treatment of stress, tension and insomnia (sleeping disorders), for muscle relaxation and sedation, for the treatment of anxiety, menopause symptoms and sexual disorders in men (Davis and Brown, 1999: Connors, 2009). Kava products such as herbal supplements, modern medicine and drinks have been widely marketed with different uses for treating a variety of diseases. Prices of those products may vary considerably (table 4-1, Appendix 9).

Several pharmaceutical companies in Europe and other countries have marketed kava lactones (e.g kavain) and kava powder (containing several lactones) to treat human diseases such as restlessness, nervousness, mental pressure, stress, psychological stress, lack of concentration and fungal infections (Davis and Brown, 1999). The active ingredients of Kava, kavalactone, is a compound that shows a mild anxiolytic effect (commonly used to reduce tension and to treat pain), and this is analgesic, causes muscle relaxation and may act as a anticonvulsant (Massey, 2002).

Stickel et al. (2003) reported that Kava potentially causes hepatotoxicity. This report is based on the discovery of 33 cases of hepatitis in Germany after the ingestion of Kava. Since 1998, some European countries report the arised on liver disorders attributed to the use of Kava as a drug (Dragull et al. 2003).

With the report of the European Association for the study of the Liver in 2003 (published by Elsevier Science BV) drugs from raw materials containing Kava were banned by the German pharmaceutical authorities (Stickel et al. 2003). Besides Germany, it is also prohibited in Canada (Connors, 2009). A ban on dietary supplement products was enacted by the American FDA (Food and Drug Administration) (Jhoo et al. 2006). This prohibition also affects the use of Kava in Indonesia. The ban on the commerce with Kava plant supplement products has 
been listed in the Decision of the National Agency of Drug and Food Control, Republic of Indonesia in Jakarta (http://www. pom.go.id, August 9, 2004).

Messey (2006) warned that heavy use of Kava may have deleterious effects on cholesterol and the kidneys. Symptoms of pulmonary hypertension have been noted with chronic consumption of large amounts of Kava. There has not been any significant toxicity recorded in association with Kava at reasonable doses. After all, the use of kava in anxiety treatment may be considered as an option for medications because of its effectiveness and its low side-effect profile. The dosage should amount of 60 to $100 \mathrm{mg}$ of kavalactone three times per day. In total, daily kavalactone intake should be restricted to $300 \mathrm{mg}$ or less per day.

Russman et al. (2003) reports that chronic heavy users of kava may consume between 1.3 and $18.6 \mathrm{~g}$ of kavalactones per day. The FDA issued a consumer advisory statement that summarized the potential risk of liver injuries associated with kava dietary supplements (Jhoo et al. 2006) U.S.FDA (U.S. Food and Drug Administration) advises that a potential risk of rare, but severe, liver injury may be associated with Kava-containing dietary supplements. Literature recommends that pregnant women shouldnot take kava. It shouldnot be combined with antidepressants or antianxiety drugs and not exceed the recommended doses or be used at along term. A healthcare professional should be asked before use if present or past liver problems are known, frequent use of alcoholic beverages, or continuous intake of any medication (http://www.physicianformulas.com/store).

Products are standardized to contain at least 15\% kavalactones (some, however, contain as much as $70 \%$ ) (Connors, 2009). It must not be used by persons under 18 years of age, or by pregnant or breastfeeding women. It shouldnot be used together with alcoholic beverages (http://www.physicianformulas.com/store).

The prohibition for pregnant or breastfeeding women of these herbal supplement products correspond to such a ban among the Marind tribe people. Indigenous popular knowledge of the Marind tribe people is thus corroborated by the scientific studies. Davis and Brown (1999) listed that indigenous knowledge of Kava in the South Pacific referred also to the medical use for the treatment of gout, rheumatism, diarrhea, asthma, venereal diseases and seizures. 


\section{Use for dowry and in ceremonies}

Using Kava plant as a dowry in Marind women is a procedure of giving customary things by the groom for the bride. It depends on the social level of a man to formally take a woman as his wife (Daeng, 2000). According to Van Ossenbruggen (Daeng 2000) it is said that the dowry involves magic and supernatural values. The value of the gift has a specific social function that reflects the balance of supernatural powers in the bride's family, as their girl is to be taken out from the family.

The main functions of dowry in the Marind tribes were analyzed by a group of students of the Philosophy and Theology faculty of the Fajar Timur University, Papua. The results show that as brotherhood among families of the bride and the groom; as a symbol that the woman belongs to her husband; as saving the groom's family from the bride's family's demands in the future; as entertainment of the bride's family; as symbol of alliance; as building up and establishing the relation among the clan, and family; and to measure the man's creativities (Anonymous, 1987).

One of ritual custom processions consists in adopting a person as a customary child, as practiced in the subgroup of Marori Menggey (in the village Wasur) of Kanum (in the villages Yanggandur, Rawa biru and Sota). The areas of the villages Wasur, Yanggandur, Rawa biru, Sota and several others are declared by the government through the decision of the Minister of Forestry No. 448/1990 as National Park, so-called Wasur National Park (Balai Taman Nasional Wasur, 2004). This park is managed by the regional government of Merauke, the relief agency of Wasur National Park and non-governmental organizations such as the WWF (World Wide Fund For Nature). The Marind people live In this park and they have lived there before it became Wasur National Park. Their economical basis is farming, hunting animals, looking for food from the forest, and catching fish in the rivers and swamps. These people have Ulayat or tradisional owners' rights of this area. They adhere to traditional rules for coping with their life in the surrounding nature. One of their customary rules is relevant to the conservation of the nature. Thus the management and the preservation of Wasur National Park is 
not only effected by the government but also by the traditional people living there and having land (hak Ulayat) rights of this area inside Wasur National Park.

In general, indigenous knowledge of the three groups of Marind tribes about identification, classification of Kava based on plant morphology, utilization, cultivation (planting, maintenance, fertilization, harvesting) of the Kava plants are similar to the indigenous knowledge of people in Fiji, Vanuatu, Samoa and the Solomon Islands. Why indigenous knowledge of Marind people is similar with people in Fiji, Vanuatu, Samoa and the Solomon Islands? Papua consists of around 250 ethnic groups (CI, 1999). Among those only Marind tribes use Kava plant. The assumption is that indigenous knowledge of using Kava plant and the cultivars by Marind tribes came from Papua New Guinea. Based on the history and mythology of Marind tribe, the ancestors of Marind tribe came from Papua New Guinea (Dumatubun, 2008). But there is no detail information about utilization and cultivation of Kava in Papua New Guinea. Therofore it is assumed that indigenous knowledge of Marind tribe came probably from Fiji, Vanuatu, Samoa and Solomon islands via Papua New Guinea.

\section{Preservation of Kava plantations}

Efforts for preserving and utilizing Kava, as by the local knowledge Marind tribes must be made. Besides that, a preservation of the Marind culture using Kava is already effected by people of Marind tribe. The Kava gardens and ritual ceremonies still performed in Marind tribe areas. However, the preservation of Kava plant in the Merauke area is not optimal because the local people plant them only according to their requirements for performing custom rituals. Conservation efforts for all variations of Kava plant in Merauke is still missing, for example the practice in such a demonstration garden or collection garden run by the government and/or non-governmental organizations in the Merauke regency. Examples of could be the Amy B.H. Greenwell Ethnobotanical Garden in Hawaii (Nelson, 2011), the Waimea Falls Park and the Arboretum Lyon, Hawaii. Such an ex situ conservation still awaits to be implemented by local governments and/or institutions, national and/or international organizations in the Merauke regency. 


\section{Marketing of Kava plants in other regions}

Kava plants have higher prices in comparison with other plants in Papua and especially in Merauke. Products derived from Kava plants from the Marind tribe area are not available on the market. In Merauke the Kava plant has not become yet an export product, as it happened in other areas of the South Pacific. Since 1990, when Vanuatu became independent from Britain and France, consumption of Kava has increased, even in areas where Kava was consumed or used as traditional medicine. In 1985, Kava growing provided an income of 1786 US-\$ per hectare per year, at a price per ton of 5870 US-\$ in Vanuatu. A revenue of 18.48 million US-\$ was reached from 69,000 hectares per year in Fiji and Tonga, at a price per ton of 4,200 US-\$ (Lebot et al. 1997). Fiji has been exporting about 50 tons of dried kava per year for local consumption mainly to Samoa and Tonga (Lebot et al. 1999). Ten tons of dried kava were exported in 1987 to European pharmaceutical companies for different kavalactone extractions (Davis and Brown, 1999). The French pharmaceutical industry purchased an average of 30 tons of dried kava rootstock annually from Vanuatu. The market remained stable, showing little fluctuation during the 1980ies (Davis and Brown, 1999). Hawaii imports some kava from Pacific islands such as Fiji and Tonga. Most Pacific nations do not need to import kava because they grow enough for their own consumption. The value or cost of the products increases with more processing and for retail consumers (Nelson, 2011). It is also reported that Kava powder ranges in price, depending on the market source and the amount purchased. Currently, the retail price is $66 \mathrm{Us}-\$ / \mathrm{kg}(30 \mathrm{US}-\$ / 1 \mathrm{~b})$ or more for dried kava powder. Prices depend on the quantity purchased, the cultivar, the region of origin and the particle size of the powder. A kava plant having a fresh harvest weight of $14.5 \mathrm{~kg}(32 \mathrm{lb})$ can produce approximately $3.6 \mathrm{~kg}(8 \mathrm{lb})$ of powder having a valued of $240 \mathrm{US}-\$$, at a retail price of $66 \mathrm{Us}-\$ / \mathrm{kg}$ (30 US-\$/lb). Fresh kava drinks (approximately $300 \mathrm{ml}(10 \mathrm{oz})$ or more) may cost several dollars a piece in Hawaii kava bars (Nelson, 2011). The sales value of Kava plant is increased after the plant is processed into supplement products, herbal medicine and modern medicine. The details of sales value of Kava products are given in see table 4-1 in appendix 9). 


\section{4-3. Grouping of morphological similarities}

The grouping pattern of Wati consisting of Piper wichimannii and Piper methysticum and its five cultivars Safurawe, Munana, Palima, Wati Kuning, and Babid. Based on cluster analysis, it shows a similarity to the grouping pattern derived from the main component analysis. The highest coefficient value was 0.91 in Piper methysticum of Safurawe and Palima cutivar. It means that these two cultivars have the closest genus relation. The lowest coefficient value was 0.1 in Piper wichimannii and Piper methysticum of the Babid cultivar. This means that both species have such a remote relation. Although there are different analysis results of the similarity coefficient between NTSYpc program version 2.20i (i.e. 1.79) and the statistical program version 8.0 (i.e. 3.0) they show the same grouping pattern for the cluster analysis results. The grouping pattern is based on the stem internode length. For this reason the same size of long internode yields a higher similarity in comparison with the other morphological components of the plant.

Lebot and Lévesque (1989) suggested a distant relationship of Piper methysticum to Macropiper on the basis of their terminal inflorescences and the presence of kavalactones. Jaramillo and Manos (2001) also suggested that Piper methysticum is related rather to Macropiper than to other Asian Piper species. Asmarayani and Pancoro (2005) reported that based on ITS area from nrDNA Piper methysticum is closely related to Macropiper excelsum, Macropiper hooglandii and Macropiper melchior. Based on the ITS area of cpDNA Jaramillo et al. (2008) also classified Piper methysticum as close to Macropiper which corresponds to the distribution of Piper in the South Pacific.

\section{4-4. Genetics and different morphologies in taxonomy}

The taxonomical status of Kava plant in Merauke was established for the two species Piper wichimannii and five cultivars of Piper methysticum (Safurawe, Munana, Palima, Wati Kuning and Babid cultivars). Nelson (2011) found that 
Piper methysticum is a variable species with about 118 known cultivars throughout the Pacific region. Each archipelago where the plant is grown usually has one or more unique cultivars. Hawaii has at least 13 unique cultivars (Davis and Brown, 1999), in Fiji there are 12 cultivars, Tonga 9 cultivars, Vanuatu 10 cultivars and Samoa 4 cultivars (table 4-1).

Tabel 4-1. Cultivar names of Piper methysticum Forst.

\begin{tabular}{|c|c|c|c|c|c|c|}
\hline No & Hawaii $*$ & Fiji ** & $\begin{array}{l}\text { Vanuatu } \\
* *\end{array}$ & Tonga $* *$ & Samoa ** & $\begin{array}{l}\text { Merauke } \\
* * * \\
\text { (Indonesia) }\end{array}$ \\
\hline 1 & Hanakapiai, & LoaKasa Leka, & Malagro & Kula 'Akau, & Le'a (type A) & Munana \\
\hline 2 & Hiwa, & Loa Kasa Balavu, & Melmel & Kula, & Le 'a (type B) & Safurawe \\
\hline 3 & Honokane Iki, & Vula Kasa Leka, & Boroghu & Leka Kula, & La'au (type A) & Wati Kuning \\
\hline 4 & Kumukua, & Vula Kasa Balavu, & Kar & Hina 'Akau, & La'au (type B) & Palima \\
\hline 5 & Mahakea, & Dokobana & Kelai & Hina, & & Babid \\
\hline 6 & Mapulehu, & Dokobana Loa, & Aigen & Leka Hina, & & \\
\hline 7 & Moi, & Qila Leka, & Tudai & Fulufalua, & & \\
\hline 8 & Nene, & Balavu, & Visul & Ata, & & \\
\hline 9 & Opihikao, & Matakaro & Puariki & Valu. & & \\
\hline 10 & Panaewa, & Matakaro Balavu, & Ahouia & & & \\
\hline 11 & Papa Eleele, & Honolulu, & & & & \\
\hline 12 & Papa Eleele Puupuu & Dama. & & & & \\
\hline 13 & Papa Kea & & & & & \\
\hline
\end{tabular}

The difference in local names of Kava plants is due to the varying names or different languages occurred in the three Marind tribe groups. The number of 70 local names may even increase if other villages are included as research areas of the Marind tribes. The local names can help people to distinguish individuals from one another in a traditional way.

The species and also cultivars of Kava plant in Merauke show different morphology characters. The morphology characters used for classification are habitus (life form), stem colour, length of stem internodes, leaf colour, thickness and softness of the leaf. While the anatomical characters showed no differences, the tissue structure of Piper wichimannii and Piper methysticum with five cultivars did. However, the anatomical form of the trichoma from Piper wichimannii and Piper methysticum differs from that of Piper gibilimbum (see chapter 3 part 3-2). 
According to Sumarnie et al. (2000), the morphology of Piper gibilimbum is similar to that of Piper methysticum. The question arises,"why the trichoma" form for two species in one genus (Piper wichimannii and Piper methysticum) is the same but that from Piper gibilimbum is different. Referring to the concept of morphological species emphasis on a different anatomy may help to identify whether a species has become a separate species (Putra and Taher, 2011). Actually, Piper is the same genus for all three species. But because of the different characteristics it is assumed to be a different species.

The genetic analysis showed that there is no genetic variation among the cultivars of Piper methysticum and neither in comparison with Piper wichimannii and Piper methysticum.

According to Sofro (1994) the ideal approach to determine the diversity of organisms involvs to find out first the genetic structure because this information is obviously not biased by environmental factors. Environmental factors can affect the quantitative properties of a plant (Hidayati and Syarif, 2002). Lebot et al. (1999) found that different cultivars of Piper methysticum planted in an homogeneous environment (soil and climate) showed to be quite variable in the kavalactone content of their roots. In all analyzed cultivars the total kavalactone content decreases from the roots to the stumps. The basal stems and the leaves exhibit lower concentrations.

According to Rifai (1976) morphology characters of Kava comprise qualitative and quantitative traits. The quantitative traits of the vegetative parts are often influenced by environmental factors. In contrast, the generative traits are usually not affected by the environment. Botanical systematics shouldn't be easily influenced by environmental factors. Variations are consistent and correlated with other properties that are not easily modified by segregation or simple recombination of genetic factors.

A possibility to prove the difference between the cultivars of Piper methysticum is to analyze the chemical content of each cultivar. A ranking based on reactions can help to classify the five cultivars that are regarded as different in the culture of the Marind tribe people and to determine the taxonomic status of Kava plant diversity in Merauke, an area with a homogenous climate. 
On the other hand, it is therefore not possible to investigate the influence of the environment on the morphological characters of Kava plants in different habitats, climates and geographical location. It is because discoloration of the stem and the leaves may occur. In the case of Piper ornatum it was the found that changes in leaf colour are due to changes in environmental conditions. For example the current habitat in Bogor, West Java compared to the geography of the native habitat in South Sulawesi on \pm 800 meter altitude, in the middle of the forest with $100 \%$ of relative shade and little humidity of the soil (Sulianti and Chairul, 2002). The city of Bogor is located at an altitude of 190 to $330 \mathrm{~m}$ above sea level. The air temperature is comparatively cool with monthly average temperatures of $26^{\circ} \mathrm{C}$ and a humidity less than $70 \%$ and the lowest average temperature in Bogor was $21.8^{\circ} \mathrm{C}$ (http://id.wikipedia.org/wiki/Kota_Bogor). In this area (Bogor) Piper growth and quantitative production of essential oils is severely influenced by ecological factors such as climate (rainfall), altitude, soil type, light intensity (shading effect), humidity and porosity of the soil (Sulianti and Chairul 2002).

Genetics can explain the different morphologies in the taxonomy of Piper species, in particular of the Piper methysticum, Piper wichimannii and Piper betle cultivars (see the other sections of the genetic experiments).

\section{4-5. Genetic diversity of Kava plant in Merauke}

\section{Genetic diversity of Kava plant in Merauke and other polyploid plant species}

Within this study, molecular markers, i.e. nuclear and chloroplast microsatellites (SSRs or simple sequence repeats) were used in order to analyse the genetic diversity of Piper methysticum, its wild relative Piper wichmannii and Piper betle. Codominant nuclear simple sequence repeats (nSSRs) may have substantial advantages over dominant anonymous markers such as amplified fragment length polymorphisms (AFLPs) (Vos et al., 1995). Therefore, nuclear SSRs developed for diploid Piper nigrum (Menezes et al., 2009) and the universal 
ccmp (chloroplast) SSRs (Weising and Gardner, 1999) were transferred to the decaploid P mystheticum, P.wichmanii and P.betle. Generally, such attempts are the most successful for closely related species $(76 \%$ transferability within the same genus and 90\% within subgenera, (Pfeiffer et al., 2011). In the case of nuclear SSRs, unfortunately, many of the advantages of codominance are lost in the study of polyploids, because the allele dosage behind a specific peak can hardly be determined (Pfeiffer et al., 2011). As a result, SSR profiles of polyploid taxa are most commonly interpreted in terms of "allele phenotypes" (Esselink et al. 2004), and peak patterns are usually coded as dominant data (Gerber et al. 2000; Andreakis et al. 2009). In addition, the peak patterns produced by the different markers (nSSRs and cpSSRs) were interpreted as phenotypes and in the case of the cpSSRs as haplotypes; but the unambiguously determination of the fragment length of the peaks and their combination allow the identification of clonal structures within the analysed species. So far only a few studies were conducted analysing the genetic diversity of these Piper species using molecular markers, e.g. AFLP markers analysed by Lebot et al., (1999).

Since Piper methysticum and P. wichmannii are decaploid with $2 \mathrm{n}=10 \mathrm{x}$ $=130$ chromosomes so in one locus 1 to 10 alleles in different combinations and dosage can be found (Lebot and Levesque, 1996b). Similar results were described for the autohexaploidy species of sweet potatoes (Ipomoe batatas) (Hidayatun, 2005). The chromosome number of Piper methysticum cultivars and the ploidy level are identical in sterile cultivars of Piper methysticum and the wild type of Piper wichmannii (Lebot and Levesque, 1996b). Most other cultivated Piper species ( $P$. betle, P. longum and P. nigrum) display a wide range of ploidy levels among their numerous vegetatively propagated cultivars (Lebot et al,. (1997).

The expression of such a high amount of alleles in Piper methysticum and P. wichmannii leads also to a high amount of potentially genotypes and since these Piper species are mainly vegetatively propagated, the genetic outcome from this kind of propagation yield clonal products (Finkeldey, 2005). Caused by the high amount of potential genotypes it is difficult to identify the progenitor of an individual plant (Escaravage et al.1998), but the method described in our investigation offers a new opportunity for the identification of clonal structures. In 
general, it is assumed that a sample recruitment from seeds is rare and infrequent in clonal plant species (Zhao et al. 2010).

\section{Genetic diversity in different populations of Kava plants in Merauke}

The genetic diversity of Kava plant in Merauke area showed not to much genetic variations differences among and within different populations. Also kavalactones isolated from the root of different Piper methysticum cultivars from a homogeneous environment (soil and climate) showed no genetic variation (Lebot et al., 1999). The reason is that the Kava plant was propagated by cuttings stem from the same parent plant and in a homogeneous environment throughout the populations. Ecological factors such as climate (rainfall), high-lying places (altitude), soil type, light intensity (shade effect), humidity and soil porosity have a large impact on the growth of Piper plants and thus quantitatively on the essential oil production (Sulianti and Chairul, 2002) but their influence is not clarified so far. It is the same for the environmental influence on the mating system of a tree (Finkeldey, 2005). Kava plant flowers are dioecious, producing male and female inflorescences on separate plants, but it does not reproduce sexually (Lebot and Levesque, 1996a).

According to Rifai (1976) environmental factors may affect quantitative traits related to the morphology of the vegetative plant but do not affect the nature of the generative plant. Thus, there is no influence on the variety within and between populations and genotypes in a homogeneous environment. However, it is conceivable that such a variety can be found in a heterogeneous environment. According to Finkeldey and Hattemer (2007) the genotypes of asexually reproduced plants are identical copies of the genotype of the original plant. Asexually reproduced progenies of a single plant are also genetically identical among each other. Thus, plants grown by vegetative (cuttings stem) will produce the same genetic diversity from one generation to the next generation. 


\section{Clonal diversity}

A total of 50 clonal products expressed by the multilocus SSR generated by 4 primers of 172 samples of Piper methysticum (22 genotypes or clones), Piper wichmannii (12 genotypes or clones) and Piper betle (16 genotypes or clones) from the Merauke area showed some identical genotypes among the individual plants per species and among the species of the populations. This is higher than for example found in Sagittaria lichuanensis (Alismataceae) in which 7 ISSR (inter simple sequence repeat) primers 22 polymorphic markers generated, leading to 9 different genotypes or clones identified among 231 analyzed samples. The low levels of clonal diversity in Sagittaria lichuanensis indicate that sexual reproduction may not have played an important role in the establishment or persistence of the Sagittaria lichuanensis populations (Zhao et al. 2010).

From literature surveys on allozyme variation in clonal plants it can be concluded that clonal populations can have a high genetic diversity. However, clonal plants may present special problems for population analysis because individuals can be recognized at two different organizational levels, genet and ramets (Escaravage et al.1998). Ramets, e.g. with the same ISSR profile (see above) have the same genotype and belong to the same genet (Zhao et al., 2010). The genotypic diversity values obtained in this study for Piper methysticum, Piper wichmannii and Piper betle are difficult to compare with other clonal plants because of the principal differences in the plant of itself. Piper methysticum and P. wichmannii (Piperaceae) are decaploid, dioecious, and asexual plants. Sagittaria lichuanensis, however, is a monoecious, sexual plant. Moreover, a different analysis program was used. The results are not comparable (see results of Zhao 2010 and Hangelbroek et al. 2002). According to Gonzales (2008), the balance between clonal and sexual reproduction can vary widely among plant populations, and the extent of clonality may be influenced by the combined effects of historical land use and variation in environmental conditions. 


\section{Genetic diversity as a tool for determining the taxonomy status of Piper methysticum variance in Merauke}

The results of genetic diversity among and within populations of the variations of Kava plants and other Piper species can support the establishing of the taxonomic status of the variety of Kava plant in Merauke. Because the genetic and anatomy data showed corresponding results but are different to the morphological character, the taxonomy status of Kava plants in Merauke area follows the morphological differences. Some botanists (Rifai, 1976) stated that it may be viable to define species based on a combination of composition and gene expression patterns because the recognition and the introduction of species will always be based on the morphological characteristics.

Based on indigenous knowledge, morphological, anatomical and genetic variations of the Kava plant in Merauke both Piper wichmannii and Piper methysticum exist. Piper methysticum consists of 5 cultivars: Babid, Wati Kuning, Safurawe, Palima and Munana. People of the South Pacific area found similar result for the Kava plant cultivated from Piper wichmannii and Piper methysticum. According to Lebot et al., (1997) cultivars of Piper methysticum are sterile cultivars selected from somatic mutants and derived form of a fertile wild form of Piper wichmannii.

In order to compare the genetic diversity found within the Merauke sample at simple sequence repeat (SSR) loci and to clarify the taxonomy status of Piper methysticum, more research for other Piper species in Papua is still needed. This will include a larger sampling across the whole island of Papua and also from other islands, and from other species belonging to the genus Piper. The discovery of new genotypes and species could reveal the biodiversity, genetic diversity and structure of the genus Piper as germplasm of biodiversity.

\section{4-6. The distribution of Kava throughout the world}

According to Barrau (1972), Malayo-Oceania spans from Malaysia and the Philippines to the Melanesian continental island (figure 5-3). Melanesia, Micronesia and Polynesia are the three principal regions of Oceania. 
Because of the skin colour of their native inhabitants Melanesia means the black archipelago. Belong to the Melanesian islands New Guinea, New Caledonia, Vanuatu, Fiji and the Solomon archipelago. Micronesia means small archipelago. These islands comprise the Marianas, Guam, Palau, the Marshall archipelago, Kiribati, Nauru and the Federal Republic of Micronesia. Polynesia means many archipelagoes. These islands comprise New Zealand, the Hawaii archipelago, the atoll Midway, Samoa, American Samoa, Tonga, Tuvalu, the Cook archipelago, French Polynesia, and Easter Island.

Based on the ethnic differences Indonesia comprises Indo-Malayan and Melanesian people (see figure 5-3). The Indo-Malayo region consists of many islands: Sumatra, Java, Nusa Tenggara Barat, Nusa Tenggara Timur, and Maluku. Along the Melanesian region, the Kava plant (Piper metysticum) is not found the Indo-Malayan region, and in a subpart of Malayan area (figure 5-3). From all islands of Indonesia only the main island of Papua is home to the Kava plant. Lebot and Lévesque (1996a), Lebot et al., (1997).

Because the Kava plant is only found in Papua the use is limited to the Melanesian culture. Hence, the cultivation inside Malayo-Oceania is found in Oceania only.

Roxburgh and Wallich (1975), however, said that Piper methysticum is native from the Malay archipelago. Lebot et al., (1997) described the distribution of the cultivars of the Kava plant's cultivar (Piper methysticum) and Piper wichimannii (a wild species of Piper methysticum) based on morphology characters, chemistry and zymotypes (figure 1-6). As the highest variety of Kava plant (Piper methysticum) occurs in Vanuatu, Vanuatu is considered as the centre of this plant species (Onwueme, 2000). 


\section{Zusammenfassung}

Die Provinz Papua birgt eine äußerst vielfältige Biodiversität, die es noch von der Forschung zu entdecken gilt. Verschiedene Pflanzen dienen als Wirkstoff und werden traditionell von den Einwohnern angewendet. Der Marind-Stamm lebt im Distrikt Merauke im südlichen Papua. Aufgrund der geographischen Gegebenheiten unterteilt sich der Marind-Stamm in drei Gruppen, die Marind pantai (oder Marind dufh), Marind rawa (oder Marind bob) und Marind darat (oder Marind degh). Eine der am häufigsten traditionell verwendeten Pflanzenarten ist Piper methysticum, das sogenannte Wati. Die Wati-Blätter enthalten aktive Substanzen, die eine sedative Wirkung haben und einen langanhaltenden Schlaf verursachen. Die pharmakologischen Effekte sind den Eingeborenen seit langem bekannt. Die Spezies wird als traditionelle Medizin und als Getränk verwendet. Daher kommt ihr eine Bedeutung für die soziale Interaktion zwischen Einzelpersonen und Gruppen der Gemeinschaft zu. Zudem zeigt Wati, das in der Region des Marind-Stammes wächst, eine hohe morphologische Diversität. Die Eingeborenen haben besondere lokale Namen für jede Sorte oder Cultivar. Aufgrund der Bedeutung von Wati ist diese Art häufig Gegenstand ethnobotanischer Studien. Diese können auf Grundlage des Wissens der drei ethnischen Gruppen hinsichtlich der morphologischen Charakterisierung, der Verwendung, dem Anbau und dem Schutz von Wati durchgeführt werden.

Die Methoden in der vorliegenden Studie umfassen Erfassungsmethoden und partizipative Beobachtungen. Die Orte für die Untersuchung wurden in 32 Dörfern gewählt. Informanten wurden nach einem zweckgeleiteten Stichprobenverfahren ausgewählt. Die Daten wurden hauptsächlich durch semistrukturierte und offene Interviews mit mehr als 100 Personen der Gemeinschaft erhoben. Diese Untersuchung verwendete zwei grundsätzliche Ansätze, den emischen und den ethnischen Ansatz. Der emische Ansatz stellt eine auf ethnologischer Forschung beruhende Methode dar, um zu einer Beschreibung der Wahrnehmung und der Vorstellung der Stammesangehörigen oder der Stelle des $\mathrm{zu}$ erforschenden Objektes $\mathrm{zu}$ gelangen. Der ethnische Ansatz wird auf Evidenzbasis von wissenschaftlicher Taxonomie und Genetik zur Analyse der Wahrnehmung und der Vorstellung von traditionellem Wissen der Bevölkerung vor Ort angewandt. Die Methoden in der botanischen Studie waren darauf gerichtet, die Taxonomie über die Analyse der gesammelten Felddaten aus den Erfassungsmethoden und der Beobachtung aufzuklären. Diese Methodologie wird zur Erstellung eines Inventars von Wati-Gärten und aller Wati-Sorten in jedem Dorf verwendet. Die Beobachtungsmethode wird zur Identifikation des spezifischen Charakters der Morphologie von Wati in den Gärten verwendet und um herauszufinden, wie die Bevölkerung vor Ort die Pflanze in ihrem alltäglichen Leben verwendet. Von Wati wurden Stiele, Blätter und Blüten zur Erstellung eines Trockenherbariums zur Bestimmung im Bogoriense Herbarium-Labor in Bogor (Indonesien) entnommen und falls nötig mit der Literatur abgeglichen. Die weltweite Verbreitung von Piper methysticum wird auf der Basis der Daten von Herbarien anderer Institutionen vorgestellt. Die genetische Diversität wurde zum Abgleich der morphologischen und anatomischen Daten von Wati untersucht. 
Genetische Studien wurden für jedes beteiligte Labor durchgeführt. Für diese genetischen Analysen wurden nuclear microsatellite markers (nSSRs) und chloroplast microsatellite markers (cpSSRs) verwendet. Die Proben von den unterschiedlichen Pflanzenpopulationen wurden gemäß der geographischen Verteilung der Marind-Gesellschaft (Land-Marind, Strand-Marind und SumpfMarind) entnommen. Frische Wati-Blätter wurden von den drei Populationen entnommen. Jede Population bestand aus 30 einzelnen Pflanzen pro Cultivar als Probe. Die Gesamtzahl der Proben belief sich auf 172. Diese Untersuchung verwendete neun nuclear microsatellite markers or Primer (nSSRs) und drei chloroplast microsatellite markers oder Primer (cpSSRs), aber nur vier Primers wurden amplifiziert: PN B5, PN D10, PN G11 und ccmp2.

Die Ergebnisse der ethnobotanischen Studie zeigten, dass Wati als heilig betrachtet und die Art bei jeder rituellen Zeremonie verwendet wird. Somit ist Wati eng mit der Kultur des Marind-Stammes verbunden. Die Prozeduren der Zubereitungsrituale und der Anbau von Wati unterscheiden sich bei den Gruppen des Marind-Stammes, aber der Verwendungszweck ist bei allen Gruppen derselbe. Das Wissen des Marind-Stammes, wie es als ein Getränk und für rituelle Zeremonien verwendet wird und wie es angebaut wird, ähnelt dem Wissen anderer Völker in der Südpazifik-Region. Im Allgemeinen wird Wati bei den drei Gruppen des Marind-Stammes unterschiedlich angewendet, identifiziert und klassifiziert, angebaut und gehandhabt. Diese Arbeit untersucht auch die Zuchtsorten von Wati hinsichtlich ihrer Morphologie (Wuchsform), Anatomie (Eigenchaften der Trichome und Stomata) und Genetik. Es zeigte sich, dass morphologische Variationen keine Entsprechung in der Genetik fanden. Die unterschiedliche Morphologie der Cultivare wird für die Klassifikation hinsichtlich des Habitus (Lebensform) (Strauchgröße $\pm 1 \mathrm{~m}, 2 \mathrm{~m}$, verglichen mit P.wichimannii mit $4 \mathrm{~m}$, der wie ein kleiner Baum aussieht), Stammfarbe (grün, bräunlich bis rot), Länge der Internodien $(1-2 \mathrm{~cm}, 2-11 \mathrm{~cm}, 4-14 \mathrm{~cm}$, verglichen mit P.wichimannii, $>15 \mathrm{~cm}$ ), Blattdicke (eher dick, dick; dünne Blätter bei P.wichimannii), Weichheit der Blätter (eher weich, eher steif; bei P.wichimannii weich). Anatomisch unterscheidet sich methysticum auf der Ebene der Art von anderen Piper-Spezies wie P.wichimannii und Piper gibilimbum durch unterschiedliche Trichome. Die Unterschiede spiegeln sich ebenfalls in der Genetik wieder: die genetische Diversität variierte nicht in der Anzahl der Allele zwischen Piper methysticum-Cultivaren in der Region Merauke, da keineunterschiedlichen Allele gefunden werden konnten, nur außerhalb der Art Piper methysticum. Die folgenden Allele konnten in den Cultivaren von Piper methysticum gefunden warden: (Cultivar Babid: 7 nSSR-Allele und 1 cpSSRAllel), (Cultivar Safurawe: 8 nSSR-Allele und $1 \mathrm{cpSSR}-A l l e l)$, (Cultivar Munana: 8 nSSR-Allele und 1 cpSSR-Allel), (Cultivar Wati Kuning: 7 nSSR-Allele und 1 cpSSR-Allel), Piper wichimannii (11 nSSR-Allele und $1 \mathrm{cpSSR}-A l l e l)$, Piper betle (17 nSSR-Allele und 2 cpSSR-Allele). Die Unterschiede zeigen eine klare Trennung auf Ebene der Art zwischen methysticum, wichimannii und betle. Innerhalb der Diversität der Populationen generierten die drei polymorphic nuclear microsatellite markers insgesamt 20 Allele in den 3 Spezies. Die Anzahl der Allele pro Locus lag im Bereich von 2 für PN G11 bis zu 11 für PN D10. Die höchste Anzahl an Polymorphismen, die in Piper methysticum für den Locus PN D10 gefunden wurden, betrug 9, bei Piper betle und Piper wichimannii sind es für 
die Loci PN D10 und PN G11 7 Allele, bei Piper methysticum auf dem Lokus PN G11 5 Allele. Bei der genetischen Diversität zwischen den Populationen ergab sich die höchste Anzahl an Allelen pro Spezies pro Population wie folgt: Piper methysticum bei den Sumpf-Marind 9 Allele, bei den Populationen der Strandund Land-Marind 8 Allele, Piper wichimannii nur bei den Land-Marind 11 Allele und Piper betle bei den Sumpf-Marind 13 Allele, bei den Land-Marind Land 11 Allele und schließlich bei den Strand-Marind 10 Allele.

Bei der Identifikation der Wati-Varianten und der Aufklärung des Status von Wati in der Region Merauke auf der Basis von indigenem Wissen als auch der Morphologie und Genetik wurde gefunden, das die Wati-Pflanze die Arten Piper wichmannii und Piper methysticum umfasst. Piper methysticum umfasst fünf Cultivare: Babid, Wati Kuning, Safurawe, Palima und Munana. Diese Verteilung von Wati (Piper methysticum und Piper wichimannii) wird nur in Melanesien, Mikronesien und Polynesien gefunden, die zentrale Regionen Ozeaniens bilden.

Zur Aufklärung des taxonomischen Status der Wati-Pflanze (Piper methysticum und Piper wichimannii) in Merauke müssen genetische Studien durchgeführt werden, um neue Haplotypen zu entdecken, die in anderen Proben von Wati aus Papua und von anderen Inseln erwartet werden. 


\section{Summary}

Papua Province harbors a very rich biodiversity yet to be discovered entirely for research. Various plants serve as a drug and are traditionally used by the community. The Marind tribe is located in the district of Merauke in Southern Papua. Based on the geographical conditions, the society of the Marind tribe is divided into three groups, namely Marind pantai (or Marind dufh), Marind rawa (or Marind bob) and Marind darat (or Marind degh). One of the most important traditionally used plant species is Piper methysticum, the so-called "Wati". Wati leaves contain active substances which have a sedative effect and cause enduring sleep. The pharmacological effects are known by the indigenous people of the tribes for long. The species is used as traditional medicine and as a beverage. Hence, it is important for social interaction between individuals and community groups. In addition, Wati growing in the region of the Marind tribe shows a high diversity in morphology. The indigenous people have specific local names for each variety or cultivar. Because of the importance of Wati the plant species is widely used in ethno-botanical studies. They can be carried out based on the knowledge of the three ethnic groups in terms of morphological characterization, utilization, cultivation and preservation of Wati.

Methods in the present study included survey methods and participatory observations. The locations of research were chosen from 32 villages. Informants were selected by using a purposive sampling technique. Data were collected mainly by semi-structural and open interviews with more than 100 people of the community. This research used two primary approaches which were the emic approach and ethnic approaches. The emic approach is a method based on ethnological research to get a description about the perception and the concept of tribal people or the location of the object to be studied. The ethnic approach is used to analyze the perception and concept of traditional knowledge of local people on evidence based on scientific taxonomy and genetics. Methods in the botanical study aimed at clarifying the taxonomy by analysis of the collected field data from the survey methods and observation. This methodology is used for inventories of the Wati plant gardens and all types of varieties of the Wati plant in each village. The observation method is used for identifying the specific character of the Wati plant morphology in the gardens and to find out how local people use the plant in their daily life. Stems, leaves and flowers were taken from Wati plants for building dry herbarium specimens for identification purposes at the Bogoriense herbarium laboratory in Bogor, Indonesia, and compared to literature, if necessary. The world-wide distribution of Piper methysticum is presented based on the data of herbarium collections of different institutions. It was looked at the genetic diversity in order to align it with morphologic and anatomic data of the Wati plant. Genetic studies were conducted in respect of each laboratory involved. For these genetic analyses nuclear microsatellite markers (nSSRs) and chloroplast microsatellite markers (cpSSRs) were used. The samples from the different plant populations were taken according to the geographical distribution of Marind society as there are Marind Land, Marind Beach and Marind Swamp. The fresh leaves of the Wati plants were taken from three populations. Each population 
consisted of 30 individual plants per cultivar as a sample. The total number of samples was 172. This research used nine nuclear microsatellite markers or primers (nSSRs) and three chloroplast microsatellite markers or primers (cpSSRs), but only four primers were amplified: PN B5, PN D10, PN G11 and ccmp2.

The results of ethno-botanical research show that Wati is considered as sacred and the species is included in every ritual ceremony. Hence, Wati is strongly linked with the culture of the Marind tribe. Procedures of processing rituals and cultivation of the Wati plant among the three groups of the Marind tribe differ but the purpose of utilization is the same throughout the groups. The knowledge of the Marind tribe how to use it as a beverage, for ritual ceremonies and how to cultivate it is similar to the knowledge of other people in the South Pacific region. In general, there is a different practice for utilization, identification and classification, cultivation and handling practice of the Wati plant among the three groups of the Marind tribe. This research also investigates the Wati cultivars under the aspects of morphology (growth form), anatomy (trichoma and stomata features) and genetics. It resulted that morphological variations show no variations in genetics (no corresponding differences). The different morphology of the cultivars is used for classification in respect of habitus (life form) (shrub size \pm 1 m, $2 \mathrm{~m}$, compared to P.wichimannii with $4 \mathrm{~m}$, looking like a small tree), stem color (green, brownish to red color), lenght of stem internodes $(1-2 \mathrm{~cm}, 2-11 \mathrm{~cm}$, 4-14 cm, compared to P.wichimannii, $>15 \mathrm{~cm}$ ), leaf thickness (rather thick, thick; P.wichimannii with thin leaves), leaf softness (rather soft, rather stiff; P. wichimannii as soft). Anatomically, methysticum differs at species level from other Piper species like P.wichimannii and Piper gibilimbum by different types of trichoma. The differences are also confirmed by genetics: Genetic diversity did not reveal any variation in the allelic richness between cultivars of Piper methysticum species in Merauke area, as no different alleles could be found, only outside of Piper methysticum species. The following alleles could be found in cultivars of Piper methysticum: (Cultivar Babid: 7 alleles of nSSRs and 1 allele of cpSSRs), (Cultivar Safurawe: 8 alleles of nSSRs and 1 allele of cpSSRs), (Cultivar Munana: 8 alleles of nSSRs and 1 allele of cpSSRs), (Cultivar Wati Kuning: 7 alleles of nSSRs and 1 allele of cpSSRs), Piper wichimannii (11 alleles of nSSRs and 1 allele of cpSSRs), Piper betle (17 alleles of nSSRs and 2 alleles of cpSSRs). The differences show a clear separation at species level methysticumwichimannii-betle. Within population diversity, the three polymorphic nuclear microsatellite markers generated a total of 20 alleles for the 3 species. The number of alleles per locus ranged from 2 for PN G11 to 11 for PN D10. The highest polymorphic level found in Piper methysticum species on PN D10 locus are 9 alleles, Piper betle and Piper wichimannii on PN D10 and PN G11 locus are 7 alleles, Piper methysticum on PN G11 locus are 5 alleles. In genetic diversity among population the highest number of alleles per species per population were: Piper methysticum in Marind Swamp with 9 alleles, Marind Beach and Marind Land populations with 8 alleles, Piper wichimannii only in Marind Land with 11 alleles and Piper betle in Marind Swamp with 13 alleles, Marind Land with 11 alleles and the last is Marind Beach with 10 alleles.

In order to identify Wati plant variants and to clarify the status of Wati plant in Merauke area based on indigenous knowledge as well as on the 
morphological and genetic character it was found that Wati plant comprises the species Piper wichmannii and Piper methysticum. Piper methysticum comprises five cultivars, namely Babid, Wati Kuning, Safurawe, Palima and Munana. This Wati plant (Piper methysticum and Piper wichimannii) distribution is only found in Melanesia, Micronesia and Polynesia which are integral regions of Oceania.

To clarify the taxonomic status of the Wati plant (Piper methysticum and Piper wichimannii) in Merauke genetic investigations need to be carried out to discover new haplotypes that are to be expected in other Wati plant samples from Papua and other islands. 


\section{REFERENCES}

Andreakis, N., Wiebe, H.C, F. Kooistra, G. Procaccini. 2009. High genetic diversity and connectivity in the polyploidy invasive seaweed Asparagopsis taxaformis (Bonnemaisoniales) in the Mediterranean, explored with microsatellite alleles and multilocus genotypes. Journal of Molecular ecology vol. 18. 212-226.

Apomfires ,F. 2002. Makanan pada komuniti adat Jae: Catatan Sepintas-Lalu Dalam Penelitian Gizil. Jurnal Antropologi Papua, Universitas Cenderawasih. Jayapura. Volume 1. No. 2, Desember 2002

Agusta A; Y. Jamal; Chairul. 1997. Analisis Komponen Kimia Daun Wati (Piper methysticum Forst.). Berita Biologi Volume 4, No. 2 \& 3, Juli 1997 \& Januari 1998.

Agusta, A. 2000. Minyak Atsiri: Tumbuhan Tropika Indonesia. Penerbit Institut Teknologi Bandung, Bandung.

Agusta A dan Yuliasri Jamal;. 2007. Komponen Tumbuhan Narkotik : Wati (Piper methysticum). Cermin Dunia Kedokteran No. 157, 2007214.

Anonymous. 1987. Perkawinan Dan Hidup Berkeluarga Suku Marind-Anim. Laporan Penelitian Mahasiswa Tingkat II Angkatan 1985. Sekolah Tinggi Filsafat dan Teologi "Fajar Timur", Jayapura.

Applequist, W. L. and Vincent Lebot. 2006. Validation of Piper methysticum var. wichimanii (Piperaceae). NOVON volume 16.

Asmarayani R. dan Adi Pancoro, 2005. Phylogenetic Study of Piper L. (Piperaceae) Based on ITS Regions of nrDNA. Floribunda volume 2 (8): 201-232. Cibinong. Bogor. Indonesia.

Backer, CA dan Bakhuizen van der Brink RC. 1963. Flora of Java 1. WoltersNoordhoff NV, Groningen.

Balai Taman Nasional Wasur. 2004. Buku informasi taman nasional wasur. Buletin. Balai Taman Nasional Wasur. Merauke, Papua.

Barrau, J. 1972. An Ethnobotanical Guide for Anthropological Research In Malayo-Oceania. UNESCO Science Cooperation Office For Southeast Asia, Paris.

Baum, S.S., R. Hill and H. Rommelspacher. 1998. Efect of Kava Extract and Individual Kavapyrones on Neurotransmitter Levels in the Nucleus 
Accumbens.Jornal Proq. Neum-Psychophamacd \&B\&d. Psychtat., Vol. 22. PP. 1105-1 120. Elsevier Science Inc. USA.

Burkill, I.H. 1935. A Dictionary Of The Economic Products Of The Malay Peninsula. Volume II. Crown Agents For The Colonies. Millbank, London.

Boellars, J. 1986. Manusia Irian; Dulu, Sekarang, Masa Depan. Penerbit Gramedia, Jakarta.

[BPS] Badan Pusat Statistik. 1997. Laporan Tahunan: Merauke dalam Angka. Badan Pusat Statistik Kabupaten Merauke, Irian Jaya.

[BPS] Badan Pusat Statistik. 2007. Laporan Tahunan: Merauke dalam Angka. Badan Pusat Statistik Kabupaten Merauke, Irian Jaya.

[CI] Conservasion International. 1999. Lokakarya Penentuan Prioritas Konservasi Keanekaragaman Hayatai Irianjaya. Laporan Akhir Conservasion Internasional. Jakarta.

Connors, M.S. 2009. The everythings. Guide to herbal rememdies. Published by Adams media. USA.

Corry, G.H. (2008). Pengaruh pemberian ekstrak tanaman Wati kultivar Palima (Piper methysticum cv. Palima) terhadap lamanya waktu tidur pada mencit (Mus musculus). Bachelor thesis. Program studi pendidikan Biologi, FKIP, Universitas Cenderawasih. Jayapura, Papua.

Cotton, C.M. (1996). Ethnobotany Principles and Applications. John Wiley and Sons Ltd. England.

Daeng, H.J. 2000. Manusia, Kebudayaan dan Lingkungan; tinjauan Antropologis. Pustaka Pelajar, Yogyakarta.

Davis and J.F Brown. 1999. Kava (Piper methysticum) in South Pacific: its importance, methods of cultiation, cultivars, diseases and pests. Australian Centre for International Agriculture Research. Canbera, Australia.

Davis, R.I, M.F. Lomavatu-Fong, L.A. McMichael, T.K. Ruabete, S. Kumar, U. Turaganivalu. 2005. Cucumber mosaic virus infection of Kava (Piper methysticum) and implications for cultural control of kava dieback disease. Journal of Australasian plant pathology, vol. 34, 377-384.

Dinas Sosial. 1972. Marind (Tujuh Puluh Tahun), Dalam Proses Akulturasi Studi Tentang Latar Belakang Keadaan Masyarakat Marind. Dinas Sosial Kabupaten Merauke, Irian Barat. 
Dragull, K., W. Y. Yoshida, C.S. Tang. 2003. Piperidine alkaloids from Piper methysticum. Journal of phytochemistry vol. 63, 193-198. Pergamon.

Djaenudin, D and M. Hendrisman. 2008. Prospek pengembangan tanaman pangan lahan kering di kabupaten Merauke. Jurnal Penelitian dan pengembangan Pertanian Vol.27 No.2 Th. 2008. Bogor.

Dumatubun, A. E. 2008. Simbol Kekuasaan: "Karona" Dalam Kebudayaan Malin Anim, Merauke, Papua. Dissertation. Indonesia University, Social and Politic Faculty. Jakarta, Indonesia.

Ekue, M. 2009. Indigenous knowledge, morphological variation and genetic diversity of Blighia sapida K.D. Koenig in Benin. Dissertation. Forest genetic and forest tree breeding, Buesgen institut. Faculty of Forest sciences and forest ecology, Georg-August Uniersity of Goettingen.

Escaravage, N., S. Questiau, A. Pornon, B. Doche, P. Taberlet. 1998. Clonal diversity in a Rhododendron ferrugineum L. (Ericaceae) population inferred from AFLP markers. Journal of Molecular ecology. Vol. 7, 975-982. Blackwell Science.

Fahn, A. 1992. Anatomi Tumbuhan. Edisi Ke-3, Gadjah Mada University Press, Yogyakarta.

Finkeldey, R. 2005. Pengantar genetika hutan tropis. Fakultas kehutanan Institut Pertanian Bogor. Translation from An Introduction to Tropical Forest Genetics. Georg-August-University Goettingen, Germany.

Finkeldey, R and H.H. Hattemer. 2007. Tropical forest genetic. Springer-Verlag Berlin Heidelberg. Germany.

Hangelbroek, H.H., N.J. Ouborg, L. Santamaria, K. Schwenk. 2000. Clonal diversity and structure within a population of the pondweed Potamogeton pectinatus foraged by Bewick's swans. Journal of Molecular ecology. Vol. 11. 2137-2150.

Hansel, R and Woelk, H. 1994. Kava Kava, Arzneimitteltherapie heute.

Phytopharmaka Band 6. Aesopus Verlag, Basel.

Hartatik, W and D. Setyorini. 2008. Pemanfaatan pupuk organik untuk meningkatkan kesuburan tanah dan kualitas tanaman. Balai Besar Litbang Sumberdaya Lahan Pertanian Badan Penelitian dan Pengembangan Pertanian. Kementerian Pertanian. Bogor.

Hidayati, N. and F. Syarif. 2002. Respon Tumbuhan Liar Berpotensi Obat Asal Papua, Wati (Piper methysticum G.Forst) pada Kondisi Lingkungan Berbeda dan Perlakuan Pupuk Organik Cair. Prosiding Simposium 
Nasional II Tumbuhan Obat dan Aromatik APINMAP. Penerbit Pusat Penelitian Biologi - LIPI, Bogor.

Heyne,K. 1987. Tumbuhan Berguna Indonesia II. Terjemahan, Badan Litbang Kehutanan Jakarta. Penerbit Yayasan Sarana Wana Jaya, Jakarta.

Heywood, V.H., R.K. Brummith., A. Culham, O. Seberg. 2007. Flowering plant families of the world. Firefly books: Ontario, Canada

Hidayatun, N. 2005. Pemanfaatan penanda SSR untuk studi keragaman genetik ubi jalar Indonesia. Tesis Magister. Program Studi Sekolah Pasca Sarjana. Institut Pertanian Bogor. 63 hlm

Jackson, B.D. 1895. Index Kewensis: Plantarum Phanerogamarum. Tomus II, Oxonii. E Prelo Clarendoniano.

Jaramillo, M and P.S. Manos. 2001. Phylogeny and patterns of flora diversity in the genus Piper (Piperaceae). American Journal of botany vol. 88 no. 4 : 706-716.

Jaramillo, A.M. 2006. Using Piper species diversity to identify conservation priorities in the Choco' Region of Colombia. Biodiversity and Conservation (2006) 15:1695-1712.

Jaramillo, A.M; Richardo C,; Christopher D.; James S.; Angela S.; Eric Tepe. 2008. A Phylogeny of the Tropical Genus Piper Using ITS and the Cloroplst Intron psbJ-petA. Journal of Systematic Botany. Volume 33 (4). Pp 647-660. By the American Society of Plant Taxonomists.

Jhoo, J.W., J. P. Freeman, C. Y. W. Ang, J.J. Mihalov. 2006. Assessment of kavalactones in kava beverage products and aqueous infusions. Journal of food science, vol. 71. No. 6. Institute of food technologists.

Kameubun, K.M.K. 2003. Aspek botani dan etnobotani Wati (Piper methysticum Forst.) dalam kehidupan suku Marind kabupaten Merauke, Papua. Thesis magister. Bogor Agriculture University. Bogor.

Kameubun, K. M.B. and Michael Muehlenberg .2009. Ethnobotany of Piper spp and species diversity of the Piper plants in Papua. First International Biodiversity Conference on Sustainable Development in Tanah Papua, 11 - 14 November 2009. Webblog: www.ibcpapua.blogspot.com.

Kubitzki et al.,. 1993. The families \& genera of vascular plants: Piperaceae. Vol. II. Flowering plants. (Dicotyledons (Magnoliid, Hamamelid \& Caryophyllid families. Springer - verlag Berlin Heidelberg. Germany.

Lawrence, G.H.M. 1957. Taxonomy of vascular plants. Macmillan, New York. 
Lebot, V and Levesque, J. 1996a. Genetic control of kavalactone chemotypes in Piper methysticum cultivars. Journal of Phytochemistry. Vol.43, no. 2. Elseivier Science.

Lebot, V and Levesque, J. 1996b. Evidence for conspecificity of Piper methysticum Forst. F. and Piper wichimannii C.DC. Journal of Biochemical systematic and ecology. Vol.24, no. 7/8.pp. 775-782. Pergamon.

Lebot V.: Mark Merlin, Lamont Lindstrom. 1997. Kava The Pacific Elixir. The Definitive Guide to Its Ethnobotany, History, and Chemistry. Healing Arts Press, Rochester, Vermont.

Lebot, V. ED Johnston, Qun Yi Zheng, Doug McKern and D. McKenna. 1999. Morphological, Phytochemical and Genetic Variation in Hawaiian Cultivars of 'Awa (Kava, Piper methysticum, Piperaceae). Jurnal Economic Botany volume 53 (4) pp 407 - 418. The New York Botanical Garden Press. Bronx. New York. USA.

Lechtenberg, M., B. Quandt, F.J. Kohlenberg dan A. Nahrstedt. 1999.

Qualitative and quantitative micellar electrokinetic chromatography of kavalactones from dry extracts of Piper methysticum Forst. and commercial drugs. Jurnal Chromatography A. 848 (457-464). Elsevier.

Massey, P. B. 2002. Dietary supplements. Medical clinis of north America, vol. 86. No.1.

Menezes, I.C., F.W. Cidade, A.P.Souza, I.C. Sampaio. 2009. Isolation and characterization of microsatellite loci in the black pepper, Piper nigrum L. (Piperaceae). Technical note on Journal of Conservation Genet Resour. Springer.

Muller, K. 2005. Keanekaragaman Hayati Tanah Papua. Universitas Negeri Papua, Manokwari.

Nelson, S.C. 2011. Farm and forestry production and marketing profile for Kava (Piper methysticum). Permanent Agriculture Resources (PAR), Holualoa, Hawai'i.

Nguyen, H. H, T.D. Xuan, T. Eiji, M. Matsuo, O. Yuichi. 2002. Evaluation of the allelopathic potential of Kava (Piper methysticum L.) for weed control in rice. Journal of Weed biology and management vol.2, 143147.

Onwueme, I.C. 2000. Piper methysticum G. Forster. Prosea-16 Stimulans. Bogor. 
Overweel, J.A. (1990). Suku Marind Dalam Alam Dan Lingkungannya Yang Berubah. Terjemahan. YAPSEL, Merauke, Irian Jaya.

Paijmans, K. (ed.). 1976. New Guinea Vegetation. Canberra: Australian National University Press.

Petocz, R.G. 1987. Konservasi Alam dan Pembangunan Irian Jaya. Penerbit Gramedia, Jakarta.

Pfeiffer, T. A. M. Roschanski, J. R. Pannell, G. Korbecka, M. Schnittler. 2011. Characterization of microsatellite loci and reliable genotyping in a polyploidy plant, Mercurialis perennis (Euphorbiaceae). Journal of heredity.

Polunin, N. 1994. Pengantar geografi tumbuhan dan beberapa ilmu serumpun. Yogyakarta: Gadjah Mada University Press.

Putra, P. and T. Taher. 2011. Definisi konsep spesis dan spesiasi. Pendidikan Biologi PPs Universitas negeri Malang, Malang.

Rawung. W.H. 2005. Menelusuri Jejak Misionaris di Papua Selatan; Seratus tahun misi gereja katolik 14 Agustus 1905-2005. Penerbit Seksi Sejarah Panitia Seratus Tahun Gereja Katolik di Papua Selatan.

Renwarin, B. 1996. Studi Kasus Tentang Pengaruh Transformasi Terhadap Partisipasi Marind Samkai Dalam Pengembangan Masyarakat Di Kelurahan Samkai Kabupaten Merauke Irian Jaya. Tessis, Universitas Kristen Satya Wacana, Salatiga.

Rideng, I.M. 1989. Taksonomi Tumbuhan Biji. Departemen Pendidikan dan Kebudayaan, Jakarta.

Rifai, M.A. 1976. Sendi-Sendi Botani Sistematika. Mimeograf. Lembaga Biologi Nasional - LIPI, Bogor.

Roxburgh,W. and N. Wallich. 1975. Flora Indica or Description of Indian Plants. Volume 1, New York.

Rusmann, S. Barguil, Y. Cabalion, P. Kritsanida, M. Duhet, D. Lauterburg, BH. 2003. Hepatic injury due to traditional aqueous extracts of kava root in New Caledonia. Eur J Gastroenterol Hepatol 15(9)

Sharma, O.P. 2009. Plant Taxonomy. Second edition. Tata Mc Graw-Hill publishing, New Delhi. ISBN (13): 978-0-07-068104-0.

Suriadikarta, A.D. and Simanungkalit, R.D.M. 2006. Pupuk organik dan pupuk hayati . Organic fertilizer and biofertilizer. Balai Besar Litbang 
Sumberdaya Lahan Pertanian Badan Penelitian dan Pengembangan Pertanian.

Sofro, A. S. 1994. Keanekaragaman genetik. Penerbit Andi offset Yogyakarta.

Stickel, F., H.M. Baumueller, K. Seitz, D. Vasilakis, G. Seitz, H. K. Seitz, D. Schuppan. 2003. Hepatitis induced by Kava (Piper methysticum rhizome). Journal of hepatology, vol. 39, 62-67. Elsevier.

Sulianti, S. B. and Chairul. 2002. Perbandingan komponen kimia penyususn minyak atsiri sirih liar (Piper ornatum) yang berasal dari Sulawesi Selatan dan pulau Seram dengan sirih biasa (Piper betle). Berita biologi, vol. 6, no. 3. LIPI, Bogor.

Sumarnie; H. Priyono; R.Subekti P; Saryadi; Amiruddin. 2000. Perbanyakan Piper gibilimbum Dengan Setek Batang Muda Perlakuan Hormon Tumbuhan Dalam Medium Cair. Laporan teknik: Bagian Proyek Pengembangan Potensi Flora dan Fauna Di Irian Jaya. Pusat Penelitian Dan Pengembangan Biologi Lembaga Ilmu Pengetahuan Indonesia, Wamena.

Swasono, S. and M. Singarmbun. 1986. Sepuluh Windhu Transmigrasi di Indonesia, 1905-1985. Jakarta, UI Press, pp. 287-297

The product "Thompson" produced from Kava (Piper methysticum) http://www.rumahfarmasi.com/thompsons-thompson-kava-2400mgtablets-p-886.html)

The product "Kava Root" (Piper methysticum) (Photo from http://www.globalsupplements.com/Kava-kava)

Van Baal, J. 1966. DEMA: Desrcription and analysis of Marind-Anim culture (South New Guinea). Amsterdam.

Van Baal. J. 1987. Sejarah dan pertumbuhan teori antropologi budaya (Hingga decade 1970). Jilid 1. Penerbit PT Gramedia, Jakarta.

Vos, 1995. AFLP: A new technicque for DNA fingerprinting. Journal of Nucl Acid res vol. 23: 4407-4414.

Walujo, E.B. 1998. Etnobotani, Metode Penelitian Baru Penggabungan Antara Konsep Ilmu- Ilmu Sosial Dan Ilmu Biologi. Prosiding Seminar Nasional Etnobotani III 5-6 Mei 1998.

Walujo, E.B. (2004). Pedoman Pengumpulan Data Keanekaragaman Flora. Pusat Penelitian Biologi, LIPI. Bogor. Indonesia. 
Warip, M. 1996. Suku Marind-Anim Di Kabupaten Merauke. Etnografi Irian Jaya. Seri 2. Pemerintah Propinsi Daerah Tingkat I, Irian Jaya.

Warip, M. 2000. Etnobotani Masyarakat Marind Di Kawasan Taman Nasional Wasur Kabupaten Merauke Papua Suatu Kajian Tentang Pengetahuan Dan Pemanfaatan Tumbuh-Tumbuhan Pada Masyarakat Marind. Usul Penelitian Untuk Thesis. Program Pascasarjana Universitas Gajah Mada, Yogyakarta.

Weising, K. and R. C. Gardner. 1999. A set conserved PCR primers for the analysis of simple sequence repeat polymorphisms in chloroplast genomes of dicotyledonous angiosperms. Journal of Genome, vol. 42. 9-19. NRC Canada.

Whiton, P.A, A. Lau, A. Salisbury, J. Whitehouse, C. S. Evans. 2003. Molecules of interest Kava lactones and the kava-kava controversy. Journal of Phytochemistry vol. 64. 673-679. Pergamon.

Xuan, T.D, O. Yuichi, C. Junko, T. Eiji, T. Hiroyuki, M. Mitsuhiro, T. D. Khanh, N. H. Hong. 2003. Kava root (Piper methysticum L.) as a potential natural herbicide and fungicide. Journal of Crop protection. Elsevier.

Xuan, T.D, S. Tawata, T. D. Khanh, I. M. Chung. 2005. Decomposition of allelopathic plants in soil. Journal of Agronomy \& Crop Science vol. 191, 162-171. Blackwell Verlag, Berlin.

Yolmen, Y. 1997. Isolasi Senyawa Alkaloid Pada Kulit Batang Tanaman Wati (Piper methysticum). Skripsi. Universitas Cenderawasih, Jayapura.

Zhao. S.Y, J.M. Chen, Q. F. Wang, F. Liu, Y. H. Guo, W. R. Gituru. 2010. The extent of clonality and genetic diversity in Sagittaria lichuanensis (Alismataceae), an endemic marsh herb in China. Journal of Botanical Studies. Vol. 51, 363-369. 
Table 3-3. Identification of parts of Wati plant by Marind Beach

\begin{tabular}{|c|c|c|c|c|c|c|c|c|c|c|c|c|}
\hline \multirow[b]{2}{*}{ Bagian tanaman } & \multicolumn{12}{|c|}{ Kampung/Desa } \\
\hline & Domande & Onggari & Kaiburse & Matara & Urumb & Kuper & Buti & Sanggase & Alatep & Makaling & Dufmira & Wambi \\
\hline Root & Itit & Itit & Itit & Itit & Itit & Itit & Itit & itit & itit & itit & itit & itit \\
\hline Stem & De & De & De & De & De & De & De & de & de & de & de & de \\
\hline Branch & Kadak da & Kadak da & Sangga & Kadak da & kadakda & Kadakda & Kadakda & kadakda & bedopaan & kadakda & kadakda & kadak \\
\hline Internode & Muk & Muk & Muk & Adina & Adina & Bong-bongga & Adina & igna & $\mathrm{de}$ & hadina & hadina & khadina \\
\hline Node & Tal & Tal & Tal & & & & Muk & muk & muk & muk & muk & muk \\
\hline Bud's nodes & Kin & Kin & Kin & & & & tabuk & kin & tabuk & kin & kin & tubatub \\
\hline Bud & \begin{tabular}{|l} 
Tabuk sai \\
\end{tabular} & Tabuk & Tabuk & Tabuk & Tabuk & Tabuk & Tabuk & tabuk & kadak/tabuk & tabuk & tabuk & tabuk \\
\hline Branch's bark & Ugu & Ugu & Ugu & & & & Par & unggu & uggu & uggu & uggu & dapa \\
\hline Leaves & Nggol & Nggol & Nggol & Nggol & Nggol & Nggol & Nggol & nggol & nggol & nggol & nggol & nggol \\
\hline Stalk of leaf & Ten & Ten & Mit & Bingg & Ten & Ten & Bingg & bing & kadak & bing & bing & bingk \\
\hline Bone of leaf & & & & & & & Nggol & hin & & hin & hin & bingk \\
\hline Fruit & Dad mi & Dada mi & Dada mi & Dadami & Dadami & Dadami & Dadami & dadmi & dadami & dadami & dadami & dadami \\
\hline Sheath & Kabu & Kabu & Kabu & & & & - & bing & kadak & bing & bing & bingk \\
\hline Bud & & & & & & & mengga & sulpi & tabuk & mengga & mengga & tabuk \\
\hline
\end{tabular}


Table 3-4. Identification of parts of Wati plant by Marind Land

\begin{tabular}{|c|c|c|c|c|c|c|c|c|c|c|c|}
\hline \multirow{2}{*}{$\begin{array}{l}\text { Bagian } \\
\text { tanaman }\end{array}$} & \multicolumn{11}{|c|}{ Kampung/Desa } \\
\hline & Kaliki & Salor & Baad & Yanggandur & Wasur & Apar & Bibikem & Sota & Muting & Kindiki & Yawimu \\
\hline Root & Danuf & Itit & Danuf & Nden/nten & Itit & Itit & matang & mint & itit & wati dunuf & wati denuh \\
\hline Stem & De & De & $\mathrm{De}$ & Beyau & Morouw/Kiwi & De & $\mathrm{pu}$ & te per & wati de & de & de \\
\hline Branch & Kadak & Kadak & Ndakr & Terah/sakla & Kwarau & Kadak & kaka & te tuti & arat & ndak & pengga \\
\hline Internode & Muk & Muk & Muk & Mput/mperper & Pireu & Muk & bap & te yelkambermber & arat & tif & de \\
\hline Node & & & & mbermber & Kumbir & & buto & tembermber & muk & muk & muk \\
\hline Bud's nodes & & & & Sih & Tobuk & & popo & te $\sin$ & kind & kind & kapol \\
\hline Bud & Kapur & Tabuk & Kuku & Ntpur/ketuh & Eyiw/ Tobuk & Tabuk & oliwo & te ketu & kind & okfa anggap & tabuk \\
\hline Branch's bark & & & & Keikei & Par & & geye & tenggau & uggu & uggu & nggu \\
\hline Leaves & Dagur & Ihul & Dadul & Dhaluh/yalwan & Yorwo & Ihul & op & teyarwan & teteka & tetek & sus \\
\hline Stalk of leaf & Tepa & Ten & Ten dadul & Bingk & Bing & Ten & gu & teyarwan tanggar & arat mit & ten & te \\
\hline Bone of leaf & & & & & Nggol & & owo & & simi & sef & \\
\hline Fruit & Karus & Dad mi & Kuma & $\begin{array}{l}\text { Mpumpuh/ko- } \\
\text { zoh }\end{array}$ & Yewi & Dad mi & mogo & tembambu & mokom & mukum & \\
\hline Sheath & & & & & Bing & & mopel & & bing & bing & baying \\
\hline Bud & & & & & Mengga & & $\mathrm{ob}$ & teyarwan peku & qatat & radat & nggol \\
\hline
\end{tabular}


Table 3-5. The local name of Wati according to Marind Land (Marind Darat / Marind degh), Marind Beach (Marind Pantai / Marind duft), Marind Swamp (Marind Rawa / Marind bob).

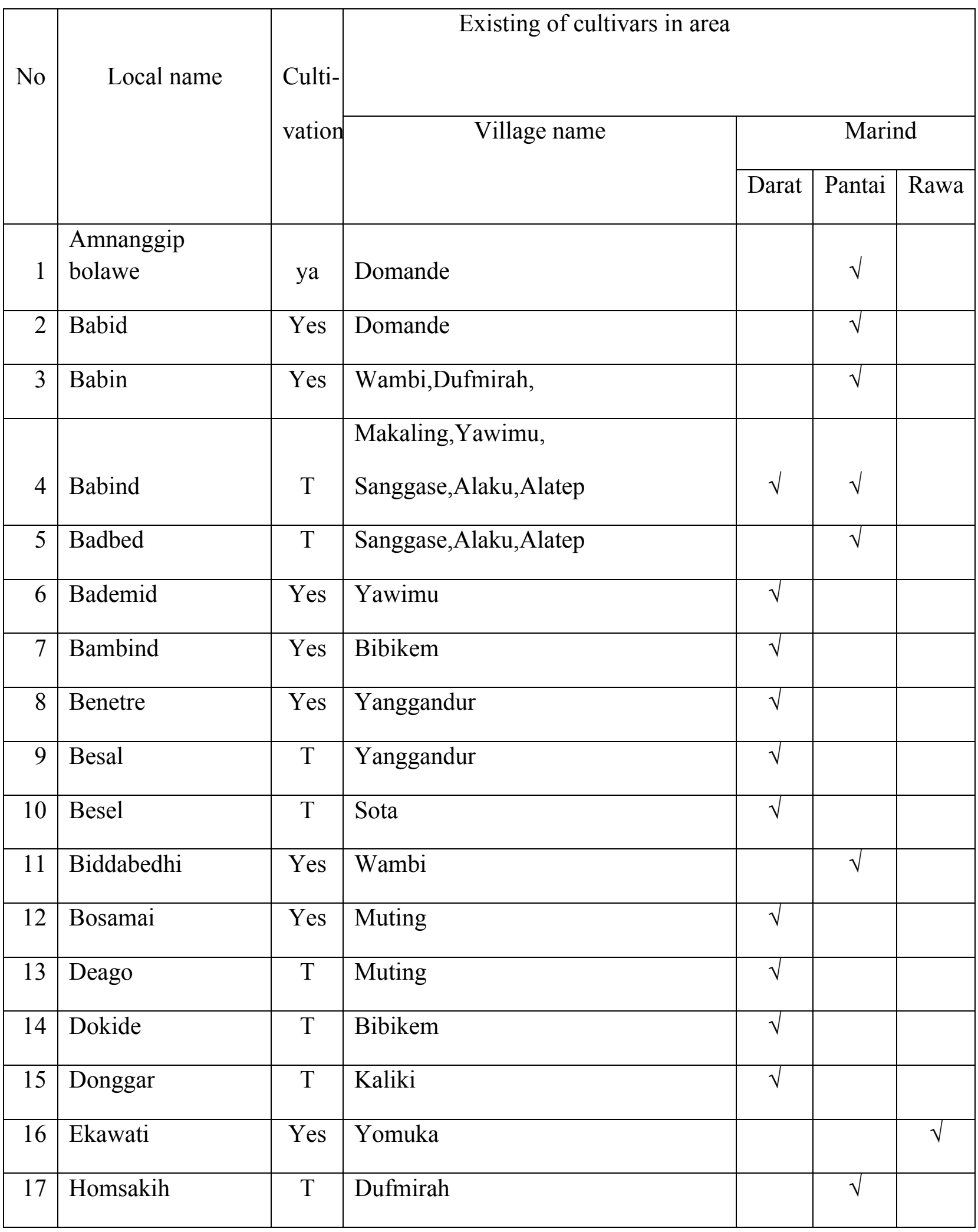




\begin{tabular}{|c|c|c|c|c|c|c|}
\hline 18 & Housah & $\mathrm{T}$ & Dufmirah & & $\sqrt{ }$ & \\
\hline 19 & Injimu kwadara & Yes & $\begin{array}{l}\text { Kimaam,Kiworo, } \\
\text { Woner,Mambun }\end{array}$ & & & $\sqrt{ }$ \\
\hline 20 & Kambilu & $\mathrm{T}$ & Makaling,Dufmirah & & $\sqrt{ }$ & \\
\hline 21 & Kambiru & $\mathrm{T}$ & Kaliki & $\sqrt{ }$ & & \\
\hline 22 & Kodara & Yes & Bamol 1\&2, Yomuka & & & $\sqrt{ }$ \\
\hline 23 & Kuadara & Yes & Iromoro & & & $\sqrt{ }$ \\
\hline 24 & Kuasanggap & $\mathrm{T}$ & Baad & $\sqrt{ }$ & & \\
\hline 25 & Kuraka & Yes & Bamol 1\&2,Iromoro & & & $\sqrt{ }$ \\
\hline 26 & Kwadara & Yes & $\begin{array}{l}\text { Kimaam,Kiworo, } \\
\text { Woner,Mambun }\end{array}$ & & & $\sqrt{ }$ \\
\hline 27 & Malokwati & Yes & Kumaaf,Kindiki & $\sqrt{ }$ & & \\
\hline 28 & Manom & $\mathrm{T}$ & Sanggase,Alaku,Alatep & & $\sqrt{ }$ & \\
\hline 29 & Marub & Yes & Yanggandur & $\sqrt{ }$ & & \\
\hline 30 & Mbasom & $\mathrm{T}$ & Bibikem & $\sqrt{ }$ & & \\
\hline 31 & Mbui & $\mathrm{T}$ & Bibikem & $\sqrt{ }$ & & \\
\hline 32 & Meve patul & $\mathrm{T}$ & Koa & $\sqrt{ }$ & & \\
\hline 33 & Meve qiwasom & $\mathrm{T}$ & Koa & $\sqrt{ }$ & & \\
\hline 34 & Munana & Yes & Makaling & & $\sqrt{ }$ & \\
\hline 35 & Namol & Yes & Bibikem & $\sqrt{ }$ & & \\
\hline 36 & Namuara & Yes & $\begin{array}{l}\text { Kimaam,Kiworo, } \\
\text { Woner,Mambun }\end{array}$ & & & $\sqrt{ }$ \\
\hline 37 & Namur & $\mathrm{T}$ & Wambi & & $\sqrt{ }$ & \\
\hline 38 & Namuru & Yes & Bamol 1\&2,Iromoro & & & $\sqrt{ }$ \\
\hline 39 & Ndik & Yes & Wambi & & $\sqrt{ }$ & \\
\hline
\end{tabular}




\begin{tabular}{|c|c|c|c|c|c|c|}
\hline 40 & Ndikawi & Yes & Yomuka & & & $\sqrt{ }$ \\
\hline 41 & Ndikay & Yes & Kimaam,Kiworo,Woner,Mambun & & & $\sqrt{ }$ \\
\hline 42 & Ndikayu & Yes & Bamol 1\&2,Iromoro & & & $\sqrt{ }$ \\
\hline 43 & Ndikpu & $\mathrm{T}$ & Bibikem & $\sqrt{ }$ & & \\
\hline 44 & Nten mber-mber & Yes & Sota & $\sqrt{ }$ & & \\
\hline 45 & Otakon & Yes & Baad & $\sqrt{ }$ & & \\
\hline 46 & Pacaka & Yes & Kimaam,Kiworo,Woner,Mambun & & & $\sqrt{ }$ \\
\hline 47 & Palima & Yes & $\begin{array}{l}\text { Makaling,Wambi,Yawimu,Dufmirah, } \\
\text { Sanggase,Alaku,Alatep,Domande } \\
\text { Imbuti,Kuper,Kaiburse,Onggari } \\
\text { Wendu, Matara, Urumb, Bahor, }\end{array}$ & $\sqrt{ }$ & $\sqrt{ }$ & \\
\hline 48 & Parima & $\mathrm{T}$ & Kaliki & $\sqrt{ }$ & & \\
\hline 49 & Prahteh & $\mathrm{T}$ & Yanggandur & $\sqrt{ }$ & & \\
\hline 50 & Purima & $\mathrm{T}$ & Yanggandur & $\sqrt{ }$ & & \\
\hline 51 & Safurawe & Yes & Kaliki & $\sqrt{ }$ & & \\
\hline 52 & Sah Ulawe & $\mathrm{T}$ & Kaiburse,Onggari & & $\sqrt{ }$ & \\
\hline 53 & Sah walawe & Yes & Makaling,Domande & & $\sqrt{ }$ & \\
\hline 54 & Sakalo & Yes & Kindiki & $\sqrt{ }$ & & \\
\hline 55 & Sakaro & Yes & Saror & $\sqrt{ }$ & & \\
\hline 56 & Salwak & Yes & Yawimu & $\sqrt{ }$ & & \\
\hline 57 & Sipul & Yes & Dufmirah,Bibikem & $\sqrt{ }$ & $\sqrt{ }$ & \\
\hline 58 & Sipur & $\mathrm{T}$ & Kaliki & $\sqrt{ }$ & & \\
\hline 59 & Tampar mber-mber & Yes & Sota & $\sqrt{ }$ & & \\
\hline 60 & Thomur & $\mathrm{T}$ & Yanggandur & $\sqrt{ }$ & & \\
\hline 61 & Tuband & $\mathrm{T}$ & Kaliki,Kindiki & $\sqrt{ }$ & & \\
\hline
\end{tabular}




\begin{tabular}{|r|l|r|l|c|c|c|}
62 & Ulawe & Yes & Kaiburse,Onggari & & $\sqrt{ }$ & \\
\hline 63 & Urawe & Yes & Koa & $\sqrt{ }$ & \\
\hline 64 & Walawe & Yes & Makaling,Dufmirah & & $\sqrt{ }$ & \\
\hline 65 & Walwe & Yes & Yomop,Sanggase,Alaku, Alatep & $\sqrt{ }$ & $\sqrt{ }$ & \\
\hline 66 & Wati & Yes & Saror,Urumb,Matara,Kuper,Imbuti & $\sqrt{ }$ & $\sqrt{ }$ & \\
\hline 67 & Wati kuning & Yes & Bamol 1\&2 & & & $\sqrt{ }$ \\
\hline 68 & Welmiemie & T & Bibikem & $\sqrt{ }$ & \\
\hline 69 & Yambrate & Yes & Sota & $\sqrt{ }$ & & \\
\hline 70 & Yone & T & Kaliki & & & \\
\hline
\end{tabular}

Note: $\mathrm{T}=$ knowing but not planting, Yes $=$ planting 


\section{Appendix 6.}

Table 3-11. Morphology character scoring of Wati plant

\begin{tabular}{lcccccc}
\hline & \multicolumn{7}{c}{ Species } \\
\cline { 2 - 7 } \multicolumn{1}{c}{ Character } & Piper wichimanii & $\begin{array}{c}\text { Pm cv } \\
\text { Safurawe }\end{array}$ & $\begin{array}{c}\text { Pm cv } \\
\text { Munana }\end{array}$ & $\begin{array}{c}\text { Pm cv Wati } \\
\text { kuning }\end{array}$ & $\begin{array}{c}\text { Pm cv } \\
\text { Babid }\end{array}$ & $\begin{array}{c}\text { Pm cv } \\
\text { Palima }\end{array}$ \\
\hline Habitus & 0 & 1 & 1 & 1 & 1 & 1 \\
Hight of plant & 2 & 1 & 1 & 1 & 0 & 1 \\
Stem color & 0 & 0 & 0 & 0 & 2 & 1 \\
Length of stem internode & 3 & 1 & 2 & 1 & 0 & 1 \\
Spots on the stem & 2 & 0 & 2 & 1 & 0 & 0 \\
Length of leaf stalk & 1 & 0 & 0 & 0 & 0 & 0 \\
Leaf length & 0 & 0 & 1 & 0 & 0 & 0 \\
Leaf width & 0 & 0 & 1 & 0 & 0 & 0 \\
Leaf color & 1 & 0 & 0 & 2 & 0 & 0 \\
Tebal helaian daun & 0 & 1 & 1 & 2 & 2 & 1 \\
Leaf softness & 0 & 1 & 1 & 2 & 2 & 1 \\
Inflorence & 1 & & & & & 0 \\
Length of inflorence & 1 & & & & & 0 \\
Color of stipula & 0 & &
\end{tabular}

Similarity matrix of Wati plant (Piper wichimannii (PWIC) and Piper methysticum of Safurawe cultivar (PSfrw), Munana cultivar (PMnn), Palima cultivar (PPlm), Wati Kuning cultivar (PWku), and Babid cultivar (PBbd)).

$\begin{array}{lcccccc} & \text { PWIC } & \text { PSfrw } & \text { PMnn } & \text { PWku } & \text { PBbd } & \text { PPlm } \\ \text { PWIC } & 1.0000000 & & & & & \\ \text { PSfrw } & 0.2727273 & 1.0000000 & & & & \\ \text { PMnn } & 0.1818182 & 0.6363636 & 1.0000000 & & & \\ \text { PWku } & 0.2727273 & 0.6363636 & 0.3636364 & 1.0000000 & & \\ \text { PBbd } & 0.1818182 & 0.5454545 & 0.2727273 & 0.5454545 & 1.0000000 & \\ \text { PPlm } & 0.1818182 & \mathbf{0 . 9 0 9 0 9 0 9} & 0.5454545 & 0.5454545 & 0.5454545 & 1.0000000\end{array}$




\section{Appendix 7.}

Table 3-15. The generated alleles of 3 nuclear microsatellites (nSSRs) and chloroplast microsatellite markers (cpSSRs).

\begin{tabular}{|c|c|c|c|c|c|c|c|}
\hline \multirow[t]{2}{*}{ No } & \multirow{2}{*}{ Locus } & \multirow{2}{*}{$\begin{array}{c}\text { Number of } \\
\text { allelele }\end{array}$} & \multirow[t]{2}{*}{ Allele } & \multicolumn{3}{|c|}{ Species } & \multirow{2}{*}{$\begin{array}{c}\text { Total Number } \\
\text { of alleles }\end{array}$} \\
\hline & & & & P. methysticum & P. wichimannii & P. betle & \\
\hline \multirow{7}{*}{1} & \multirow{7}{*}{ PN B5 Locus } & 1 & 253 & 0 & 0 & 3 & \\
\hline & & 2 & 254 & 0 & 0 & 1 & \\
\hline & & 3 & 257 & 96 & 26 & 0 & \\
\hline & & 4 & 258 & 0 & 26 & 0 & \\
\hline & & 5 & 260 & 0 & 0 & 18 & \\
\hline & & 6 & 261 & 0 & 0 & 1 & \\
\hline & & 7 & 262 & 0 & 0 & 26 & 197 \\
\hline \multirow{11}{*}{2} & \multirow{11}{*}{ PN D10 Locus } & 8 & 201 & 0 & 16 & 1 & \\
\hline & & 9 & 202 & 1 & 16 & 1 & \\
\hline & & 10 & 203 & 18 & 0 & 0 & \\
\hline & & 11 & 204 & 12 & 0 & 0 & \\
\hline & & 12 & 206 & 0 & 0 & 2 & \\
\hline & & 13 & 207 & 48 & 26 & 0 & \\
\hline & & 14 & 208 & 94 & 26 & 26 & \\
\hline & & 15 & 209 & 13 & 26 & 27 & \\
\hline & & 16 & 210 & 39 & 26 & 1 & \\
\hline & & 17 & 211 & 91 & 26 & 1 & \\
\hline & & 18 & $219^{*}$ & 1 & 0 & 0 & 538 \\
\hline \multirow{9}{*}{3} & \multirow{9}{*}{ PN G11 Locus } & 19 & 199 & 0 & 0 & 27 & \\
\hline & & \multirow[t]{8}{*}{20} & 200 & 0 & 0 & 25 & \\
\hline & & & 203 & 95 & 26 & 27 & \\
\hline & & & 204 & 95 & 26 & 27 & \\
\hline & & & 207 & 9 & 14 & 22 & \\
\hline & & & 208 & 10 & 16 & 9 & \\
\hline & & & 209 & 0 & 3 & 6 & \\
\hline & & & 210 & 0 & 4 & 0 & \\
\hline & & & 211 & 1 & 3 & 0 & 445 \\
\hline \multirow{3}{*}{4} & \multirow{3}{*}{ ccmp2 Locus } & 21 & 240 & 96 & 0 & 0 & \\
\hline & & 22 & 241 & 0 & 26 & 10 & \\
\hline & & 23 & 243 & 0 & 0 & 17 & 149 \\
\hline & & Total allele & 24 & 15 & 16 & 19 & \\
\hline
\end{tabular}

*Private allele 
Table 3-18. Composition of the clonal structures in Piper methysticum, Piper wichimannii, and Piper betle based on the combination of fragment sizes of nSSR- and cpSSR- markers.

\begin{tabular}{|c|c|c|c|c|c|c|c|c|c|c|c|c|c|c|c|c|c|}
\hline \multirow{2}{*}{ Clone } & \multirow{2}{*}{\begin{tabular}{|r} 
cpSSRs \\
ccmp2
\end{tabular}} & \multicolumn{16}{|c|}{ nSSRs } \\
\hline & & \multicolumn{2}{|c|}{ B5 } & \multicolumn{7}{|c|}{ D10 } & \multicolumn{7}{|c|}{ G11 } \\
\hline C01 & 240 & 257 & & 207 & 208 & 210 & & & & & 203 & 204 & & & & & \\
\hline C02 & 240 & 257 & & 203 & 204 & 207 & 208 & 210 & 211 & & 203 & 204 & & & & & \\
\hline $\mathrm{C03}$ & 240 & 257 & & 207 & 208 & 210 & 211 & & & & 203 & 204 & & & & & \\
\hline C04 & 240 & 257 & & 203 & 207 & 208 & 210 & 211 & & & 203 & 204 & & & & & \\
\hline C05 & 240 & 257 & & 208 & 211 & & & & & & 203 & 204 & & & & & \\
\hline C06 & 240 & 257 & & 203 & 204 & 207 & 208 & 211 & & & 203 & 204 & & & & & \\
\hline C07 & 240 & 257 & & 202 & 203 & 207 & 208 & 210 & 211 & & 203 & 204 & & & & & \\
\hline C08 & 240 & 257 & & 208 & & & & & & & 203 & 204 & & & & & \\
\hline C09 & 240 & 257 & & 207 & 208 & 211 & & & & & 203 & 204 & & & & & \\
\hline C10 & 240 & 257 & & 208 & 211 & 219 & & & & & 203 & 204 & & & & & \\
\hline C11 & 240 & 257 & & 208 & 210 & 211 & & & & & 203 & 204 & & & & & \\
\hline C12 & 240 & 257 & & 203 & 207 & 208 & 211 & & & & 203 & 204 & & & & & \\
\hline C13 & 240 & 257 & & 204 & 208 & 211 & & & & & 203 & 204 & & & & & \\
\hline C14 & 240 & 257 & & 208 & 211 & & & & & & 203 & & & & & & \\
\hline C15 & 240 & 257 & & 208 & & & & & & & 203 & 204 & 207 & & & & \\
\hline C16 & 240 & 257 & & 203 & 208 & 211 & & & & & 203 & 204 & & & & & \\
\hline C17 & 240 & 257 & & 208 & 211 & & & & & & 203 & 204 & 207 & & & & \\
\hline C18 & 240 & 257 & & 207 & 208 & 210 & 211 & & & & 204 & & & & & & \\
\hline C19 & 240 & 257 & & 207 & 208 & 209 & 210 & 211 & & & 203 & 204 & 208 & & & & \\
\hline C20 & 240 & 257 & & 207 & 208 & 209 & 210 & 211 & & & 203 & 204 & 207 & 208 & 211 & & \\
\hline C21 & 240 & 257 & & 207 & 208 & 209 & 210 & 211 & & & 203 & 204 & 207 & 208 & & & \\
\hline C22 & 240 & 257 & & 207 & 208 & 209 & 210 & 211 & & & 203 & 204 & 208 & & & & \\
\hline C23 & 240 & 257 & & 207 & 208 & 209 & 210 & 211 & & & 203 & 204 & & & & & \\
\hline C24 & 241 & 257 & 258 & 201 & 202 & 207 & 208 & 209 & 210 & 211 & 203 & 204 & & & & & \\
\hline C25 & 241 & 257 & 258 & 201 & 202 & 207 & 208 & 209 & 210 & 211 & 203 & 204 & 207 & 208 & 209 & 210 & 211 \\
\hline C26 & 241 & 257 & 258 & 201 & 202 & 207 & 208 & 209 & 210 & 211 & 203 & 204 & 207 & 208 & & & \\
\hline C27 & 241 & 257 & 258 & 207 & 208 & 209 & 210 & 211 & & & 203 & 204 & & & & & \\
\hline C28 & 241 & 257 & 258 & 207 & 208 & 209 & 210 & 211 & & & 203 & 204 & 207 & & & & \\
\hline C29 & 241 & 257 & 258 & 201 & 202 & 207 & 208 & 209 & 210 & 211 & 203 & 204 & 207 & 208 & 209 & 210 & \\
\hline C30 & 241 & 257 & 258 & 201 & 202 & 207 & 208 & 209 & 210 & 211 & 203 & 204 & 207 & & & & \\
\hline C31 & 241 & 257 & 258 & 207 & 208 & 209 & 210 & 211 & & & 203 & 204 & 207 & 208 & 210 & 211 & \\
\hline C32 & 241 & 257 & 258 & 207 & 208 & 209 & 210 & 211 & & & 203 & 204 & 208 & & & & \\
\hline C33 & 241 & 257 & 258 & 201 & 202 & 207 & 208 & 209 & 210 & 211 & 203 & 204 & 211 & & & & \\
\hline C34 & 241 & 257 & 258 & 201 & 202 & 207 & 208 & 209 & 210 & 211 & 203 & 204 & 208 & & & & \\
\hline C35 & 241 & 260 & 262 & 208 & 209 & & & & & & 199 & 203 & 204 & 208 & 209 & & \\
\hline C36 & 241 & 260 & 262 & 208 & 209 & & & & & & 199 & 200 & 203 & 204 & 208 & 209 & \\
\hline C37 & 243 & 262 & & 208 & 209 & & & & & & 199 & 200 & 203 & 204 & 207 & & \\
\hline C38 & 243 & 254 & 262 & 208 & 209 & & & & & & 199 & 200 & 203 & 204 & 207 & & \\
\hline C39 & 241 & 260 & 262 & 208 & 209 & & & & & & 199 & 200 & 203 & 204 & 207 & & \\
\hline $\mathrm{C} 40$ & 241 & 260 & 262 & 208 & 209 & & & & & & 199 & 200 & 203 & 204 & 207 & & \\
\hline C41 & 243 & 260 & 262 & 208 & 209 & & & & & & 199 & 200 & 203 & 204 & 207 & & \\
\hline C42 & 243 & 260 & 262 & 208 & 209 & & & & & & 199 & 200 & 203 & 204 & 207 & 209 & \\
\hline C43 & 243 & 260 & 262 & 201 & 202 & 208 & 209 & 210 & 211 & & 199 & 200 & 203 & 204 & 207 & & \\
\hline $\mathrm{C} 44$ & 243 & 262 & & 208 & 209 & & & & & & 199 & 200 & 203 & 204 & 207 & 208 & \\
\hline $\mathrm{C} 45$ & 243 & 253 & 261 & 208 & 209 & & & & & & 199 & 200 & 203 & 204 & 207 & 208 & \\
\hline C46 & 241 & 260 & 262 & 206 & 208 & 209 & & & & & 199 & 200 & 203 & 204 & 208 & & \\
\hline C47 & 243 & 253 & 262 & 208 & 209 & & & & & & 199 & 200 & 203 & 204 & 207 & & \\
\hline $\mathrm{C} 48$ & 241 & 260 & 262 & 208 & 209 & & & & & & 199 & 200 & 203 & 204 & 208 & & \\
\hline C49 & 243 & 262 & & 209 & & & & & & & 199 & 200 & 203 & 204 & 207 & & \\
\hline C50 & 241 & 260 & 262 & 206 & 208 & 209 & & & & & 199 & 200 & 203 & 204 & & & \\
\hline
\end{tabular}


Appendix 8. Herbarium specimen data

Table 3-19. Herbarium specimen of Piper methysticum collection, the 2009's and 2010 data

\begin{tabular}{|c|c|c|c|c|c|c|}
\hline $\begin{array}{c}\text { Date, } \\
\text { year, of } \\
\text { collection }\end{array}$ & $\begin{array}{l}\text { Local name } \\
\text { of } \\
\text { Piper } \\
\text { methysticum }\end{array}$ & Area & Island & Country & $\begin{array}{l}\text { Altitude } \\
\text { (meter) }\end{array}$ & $\begin{array}{c}\text { Specimen } \\
\text { Herbarium }\end{array}$ \\
\hline $\begin{array}{l}6 \text { Feb } \\
1971\end{array}$ & $\begin{array}{l}\text { Wati Pois } \\
\text { (bahasa } \\
\text { Boasi) }\end{array}$ & $\begin{array}{l}\text { danau Herbart } \\
\text { Hoover, Bosset }\end{array}$ & $\begin{array}{l}\text { Papua } \\
\text { New } \\
\text { Guinea }\end{array}$ & $\begin{array}{l}\text { Papua } \\
\text { New } \\
\text { Guinea } \\
\text { (PNG) }\end{array}$ & & $\begin{array}{l}\text { Bogor dan } \\
\text { Kew, } \\
\text { Leiden }\end{array}$ \\
\hline \multirow[t]{4}{*}{$\begin{array}{l}10 \quad \text { April } \\
1889\end{array}$} & & $\begin{array}{ll}\text { pulau } & \text { Kaiser } \\
\text { Wilhelm } & \end{array}$ & $\begin{array}{l}\text { Papua / } \\
\text { New } \\
\text { Guinea }\end{array}$ & $\begin{array}{l}\text { Papua } \\
\text { New } \\
\text { Guinea } \\
\text { (PNG) }\end{array}$ & & $\begin{array}{l}\text { Bogor dan } \\
\text { Kew }\end{array}$ \\
\hline & & $\begin{array}{l}\text { New Pommern, } \\
\text { Bei Massawa }\end{array}$ & $\begin{array}{l}\text { Papua / } \\
\text { New } \\
\text { Guinea }\end{array}$ & $\begin{array}{l}\text { Papua } \\
\text { New } \\
\text { Guinea } \\
\text { (PNG) }\end{array}$ & & Kew \\
\hline & & $\begin{array}{l}\text { Nova Guinea } \\
\text { neerlandica } \\
\text { meridionalis, } \\
\text { Haku }\end{array}$ & $\begin{array}{l}\text { Papua / } \\
\text { New } \\
\text { Guinea }\end{array}$ & $\begin{array}{l}\text { Papua } \\
\text { New } \\
\text { Guinea } \\
\text { (PNG) }\end{array}$ & & Kew \\
\hline & $\begin{array}{l}\text { Huijo } \\
\text { (Bahasa } \\
\text { Huijo) }\end{array}$ & $\begin{array}{l}\text { Sungai Purari, } \\
\text { Gulf }\end{array}$ & $\begin{array}{l}\text { Papua / } \\
\text { New } \\
\text { Guinea }\end{array}$ & $\begin{array}{l}\text { Papua } \\
\text { New } \\
\text { Guinea } \\
\text { (PNG) }\end{array}$ & 15 & Leiden \\
\hline $\begin{array}{l}1 \text { Juni } \\
1985\end{array}$ & & $\begin{array}{l}\text { Tembagapura, } \\
\text { Mimika }\end{array}$ & $\begin{array}{l}\text { New } \\
\text { Guinea }\end{array}$ & Indonesia & 2100 & Bogor \\
\hline $\begin{array}{l}5 \text { Mei } \\
1973\end{array}$ & & $\begin{array}{l}\text { Tagiya,Emaideni, } \\
\text { Komopa, } \\
\text { Enarotali }\end{array}$ & $\begin{array}{l}\text { New } \\
\text { Guinea }\end{array}$ & Indonesia & & $\begin{array}{l}\text { Bogor dan } \\
\text { Leiden }\end{array}$ \\
\hline $\begin{array}{l}18 \text { Mei } \\
2003\end{array}$ & Wayo & $\begin{array}{l}\text { Kulagaema, } \\
\text { Wamena }\end{array}$ & $\begin{array}{l}\text { New } \\
\text { Guinea }\end{array}$ & Indonesia & 1500 & Bogor \\
\hline $\begin{array}{l}13 \text { Okt } \\
1994\end{array}$ & & $\begin{array}{l}\text { Hutan } \\
\text { Wagendah, } \\
\text { kampung } \\
\text { Wurigelebur, } \\
\text { Wamena }\end{array}$ & $\begin{array}{l}\text { New } \\
\text { Guinea }\end{array}$ & Indonesia & 1200 & $\begin{array}{l}\text { Bogor dan } \\
\text { Kew }\end{array}$ \\
\hline \multirow[t]{2}{*}{$\begin{array}{l}1 \text { Sept } \\
1907\end{array}$} & Wati & $\begin{array}{l}\text { Kampung Alaku, } \\
\text { Okaba, Mearuke }\end{array}$ & $\begin{array}{l}\text { New } \\
\text { Guinea }\end{array}$ & Indonesia & & $\begin{array}{l}\text { Bogor dan } \\
\text { Leiden }\end{array}$ \\
\hline & & Merauke & $\begin{array}{l}\text { New } \\
\text { Guinea }\end{array}$ & Indonesia & & Bogor \\
\hline $\begin{array}{l}15 \text { Nov } \\
1930\end{array}$ & & $\begin{array}{l}\text { Hutan Cyathea- } \\
\text { Neonauclea } \\
\text { Distrik } \\
\text { Hitiaa,Puunui, } \\
\text { Tahiti }\end{array}$ & & & $1090 \mathrm{ft}$ & Bogor \\
\hline $\begin{array}{l}21 \text { Sept } \\
1930\end{array}$ & & $\begin{array}{l}\text { Distrik Papenoo, } \\
\text { Orofena, Tahiti }\end{array}$ & Society & $\begin{array}{l}\text { French } \\
\text { Polynesia }\end{array}$ & $\begin{array}{l}1515 \mathrm{ft}, \\
300 \mathrm{~m}\end{array}$ & $\begin{array}{l}\text { Bogor dan } \\
\text { Leiden }\end{array}$ \\
\hline $\begin{array}{l}12 \text { Agust } \\
1909\end{array}$ & & $\begin{array}{l}\text { Lembah } \\
\text { Inoonlua, Oahu }\end{array}$ & Hawaiian & USA & & Bogor \\
\hline $30 \quad$ Okt & & Honolulu & Hawaiian & USA & & Bogor dan \\
\hline
\end{tabular}




\begin{tabular}{|c|c|c|c|c|c|c|}
\hline 1934 & & & & & & Leiden \\
\hline $\begin{array}{l}19 \text { Jan } \\
1940\end{array}$ & Kava inu & $\begin{array}{l}\text { Dekat dwelling, } \\
\text { Tamakautoga }\end{array}$ & & & 15 & Bogor \\
\hline $\begin{array}{l}28 \text { Des } \\
1932\end{array}$ & & $\begin{array}{l}\text { Lembah } \\
\text { Mapulehu, } \\
\text { Molokai }\end{array}$ & Hawaiian & USA & & $\begin{array}{l}\text { Canbera } \\
\text { dan } \\
\text { Leiden }\end{array}$ \\
\hline $\begin{array}{l}31 \text { Des } \\
1930\end{array}$ & & $\begin{array}{l}\text { Napali coast, } \\
\text { Hanakapiai, } \\
\text { Kauia }\end{array}$ & Hawaiian & USA & & $\begin{array}{l}\text { Canbera } \\
\text { dan } \\
\text { Leiden }\end{array}$ \\
\hline $\begin{array}{l}22 \text { Des } \\
1946\end{array}$ & & $\begin{array}{l}\text { Kaueleau, distrik } \\
\text { Puna }\end{array}$ & Hawaiian & USA & & $\begin{array}{l}\text { Canbera } \\
\text { dan } \\
\text { Leiden }\end{array}$ \\
\hline $\begin{array}{l}1 \text { Des } \\
1926\end{array}$ & & $\begin{array}{l}\text { Lembah } 3 r d, \\
\text { Faaroa Bay }\end{array}$ & Society & $\begin{array}{l}\text { French } \\
\text { Polynesia }\end{array}$ & & Canbera \\
\hline & & Pahoa, Hawaii & Hawaiian & USA & & Leiden \\
\hline & & Waiahole, Oahu & Hawaiian & USA & & Leiden \\
\hline & & $\begin{array}{l}\text { Lembah Halawa, } \\
\text { Molokai }\end{array}$ & Hawaiian & USA & & Leiden \\
\hline & & $\begin{array}{ll}\text { Sungai } & \text { Nanpil, } \\
\text { Ponape } & \\
\end{array}$ & Caroline & Micronesia & & Leiden \\
\hline & $\begin{array}{l}\text { Kavakava } \\
\mathrm{Tu}\end{array}$ & $\begin{array}{l}\text { Toovii, } \\
\text { Hiva }\end{array}$ & Marquesas & $\begin{array}{l}\text { Prench } \\
\text { Polynesia }\end{array}$ & & Leiden \\
\hline & & $\begin{array}{l}\text { Lyon Arboretum, } \\
\text { Oahu }\end{array}$ & Hawaiian & USA & & Leiden \\
\hline & Kawa & Danau Lanuto & Upolu & Samoa & & \\
\hline & & Alkmaar Bivouac & $\begin{array}{l}\text { Irian } \\
\text { Jaya/Papua, } \\
\text { New } \\
\text { Guinea }\end{array}$ & Indonesia & & Leiden \\
\hline & Yanggona & $\begin{array}{l}\text { Ndakuivuna, } \\
\text { Tailevu }\end{array}$ & Viti Levu & Fiji & & Leiden \\
\hline & Yanggona & $\begin{array}{l}\text { Pegunungan } \\
\text { Nairosa, Mba }\end{array}$ & Viti Levu & Fiji & & Leiden \\
\hline & Kava & Lakepa & Niue & $\begin{array}{l}\text { New } \\
\text { Zealand }\end{array}$ & & Leiden \\
\hline & & $\begin{array}{l}\text { Pegunungan } \\
\text { Koolau, Oahu }\end{array}$ & Hawaiian & USA & & Leiden \\
\hline
\end{tabular}


Table 3-20. Herbarium specimen of Piper wichimannii collection, 2009's and 2010 data

\begin{tabular}{|c|c|c|c|c|c|c|}
\hline $\begin{array}{c}\text { Date, } \\
\text { year, of } \\
\text { collection }\end{array}$ & $\begin{array}{c}\text { Scientific } \\
\text { name and } \\
\text { local name }\end{array}$ & Area & Island & Country & $\begin{array}{c}\text { Altitude } \\
\text { (meter) }\end{array}$ & $\begin{array}{c}\text { Specimen } \\
\text { Herbarium }\end{array}$ \\
\hline- & $\begin{array}{l}\text { Piper } \\
\text { wichimanii }\end{array}$ & - & $\begin{array}{l}\text { Papua / New } \\
\text { Guinea }\end{array}$ & $\begin{array}{l}\text { Papua } \\
\text { New } \\
\text { Guinea } \\
\text { (PNG) }\end{array}$ & & Leiden \\
\hline- & $\begin{array}{l}\text { Piper } \\
\text { wichimanii var } \\
\text { erectum }\end{array}$ & & Solomon & & & Leiden \\
\hline- & $\begin{array}{l}\text { Piper } \\
\text { wichimanii var } \\
\text { wachimannii }\end{array}$ & & Solomon & & & Leiden \\
\hline 1910 & $\begin{array}{l}\text { Piper } \\
\text { wichimanii. } \\
\text { C.DC }\end{array}$ & $\begin{array}{l}\text { Vulolo, } \\
\text { Pegunungan } \\
\text { Tutuve }\end{array}$ & Solomon & & 1200 & Bogor \\
\hline & $\begin{array}{l}\text { Piper } \\
\text { wichimanii } \\
\text { dan Calum- } \\
\text { bau }\end{array}$ & - & Guadalcanal & & & Bogor \\
\hline $\begin{array}{l}29 \text { April } \\
1931\end{array}$ & $\begin{array}{l}\text { Piper } \\
\text { wichimanii } \\
\text { dan Wild kava }\end{array}$ & $\begin{array}{l}\text { Kieta: } \\
\text { Bougenville }\end{array}$ & Solomon & & & Bogor \\
\hline $\begin{array}{l}16 \text { April } \\
1930\end{array}$ & $\begin{array}{l}\text { Piper } \\
\text { wichimanii }\end{array}$ & $\begin{array}{l}\text { Kampung } \\
\text { Kupei: } \\
\text { Bougainville }\end{array}$ & Solomon & & & Bogor \\
\hline $\begin{array}{l}5 \text { Agustus } \\
1932\end{array}$ & $\begin{array}{l}\text { Piper } \\
\text { wichimanii }\end{array}$ & $\begin{array}{l}\text { Waimuri } \\
\text { pulau San } \\
\text { Cristoval }\end{array}$ & Solomon & & & Bogor \\
\hline 1906 & $\begin{array}{l}\text { Piper } \\
\text { wichimanii } \\
\text { C.DC }\end{array}$ & & New Guinea & $\begin{array}{l}\text { Papua } \\
\text { New } \\
\text { Guinea } \\
\text { (PNG) } \\
\end{array}$ & & Bogor \\
\hline 1910 & $\begin{array}{l}\text { Piper } \\
\text { wichimanii } \\
\text { C.DC }\end{array}$ & $\begin{array}{l}\text { New } \\
\text { Pommern, } \\
\text { Bei Massawa }\end{array}$ & New Guinea & $\begin{array}{l}\text { Papua } \\
\text { New } \\
\text { Guinea } \\
\text { (PNG) }\end{array}$ & & Bogor \\
\hline 1910 & $\begin{array}{l}\text { Piper } \\
\text { wichimanii } \\
\text { C.DC }\end{array}$ & $\begin{array}{l}\text { Malalia, New } \\
\text { Britain }\end{array}$ & New Guinea & $\begin{array}{l}\text { Papua } \\
\text { New } \\
\text { Guinea } \\
\text { (PNG) }\end{array}$ & & Bogor \\
\hline 1910 & $\begin{array}{l}\text { Piper } \\
\text { wichimanii } \\
\text { C.DC }\end{array}$ & $\begin{array}{l}\text { Kampung } \\
\text { Galilo }\end{array}$ & & & & Bogor \\
\hline- & $\begin{array}{l}\text { Piper } \\
\text { wichimanii } \\
\text { C.DC }\end{array}$ & Massangeb & & & 700 & Bogor \\
\hline- & $\begin{array}{l}\text { Piper } \\
\text { wichimanii } \\
\text { C.DC }\end{array}$ & Nanangeb & & & 100 & Bogor \\
\hline
\end{tabular}




\section{Appendix 9}

Table 4-1. The value products of Kava (Piper methysticum)

\begin{tabular}{|c|c|c|c|c|c|}
\hline For & Product name & Use & Netto & Price & $\begin{array}{l}\text { Form of } \\
\text { product }\end{array}$ \\
\hline Medicin & $\begin{array}{l}\text { Gaia Herbs: Kava } \\
\text { kava }\end{array}$ & Relaxation & 60 pics & $\$ 19.49$ & liquid capsul \\
\hline Herbal suplement & Good Night RX & sleep (Insomnia) & 60 pics & $\$ 18.95$ & capsul \\
\hline Medicin & Kava extract & Stress, nervous tension & 1 botle & $\$ 12.95$ & pills \\
\hline Herbal suplement & Now Kava Kava & & 1 botle & $\$ 18.49$ & \\
\hline Herbal suplement & Now Menopause suppor & & 1 botle & $\$ 8.99$ & \\
\hline Beverage & Guick Kava Premium & & $1 \mathrm{~kg}$ & $\$ 295.00$ & \\
\hline Beverage & Pentecost Pride & & $1 \mathrm{~kg}$ & $\$ 96.95$ & \\
\hline Beverage & Kava strips & & 5 pack & $\$ 7.95$ & \\
\hline \multirow[t]{2}{*}{ Beverage } & Coconut Kava & & $250 \mathrm{gr}$ & $\$ 39.95$ & \\
\hline & & & $500 \mathrm{gr}$ & $\$ 69.95$ & \\
\hline Beverage & Tanna Kava-Kaollik & & $1 \mathrm{~kg}$ & $\$ 109.95$ & \\
\hline Beverage & Kava cola & & $330 \mathrm{ml}$ & & \\
\hline \multirow[t]{3}{*}{ Beverage } & Malekula Magic & & $500 \mathrm{gr}$ & $\$ 62.95$ & \\
\hline & & & $250 \mathrm{gr}$ & $\$ 36.95$ & \\
\hline & & & $1 \mathrm{~kg}$ & $\$ 91.95$ & \\
\hline
\end{tabular}




\section{Appendix 1.}

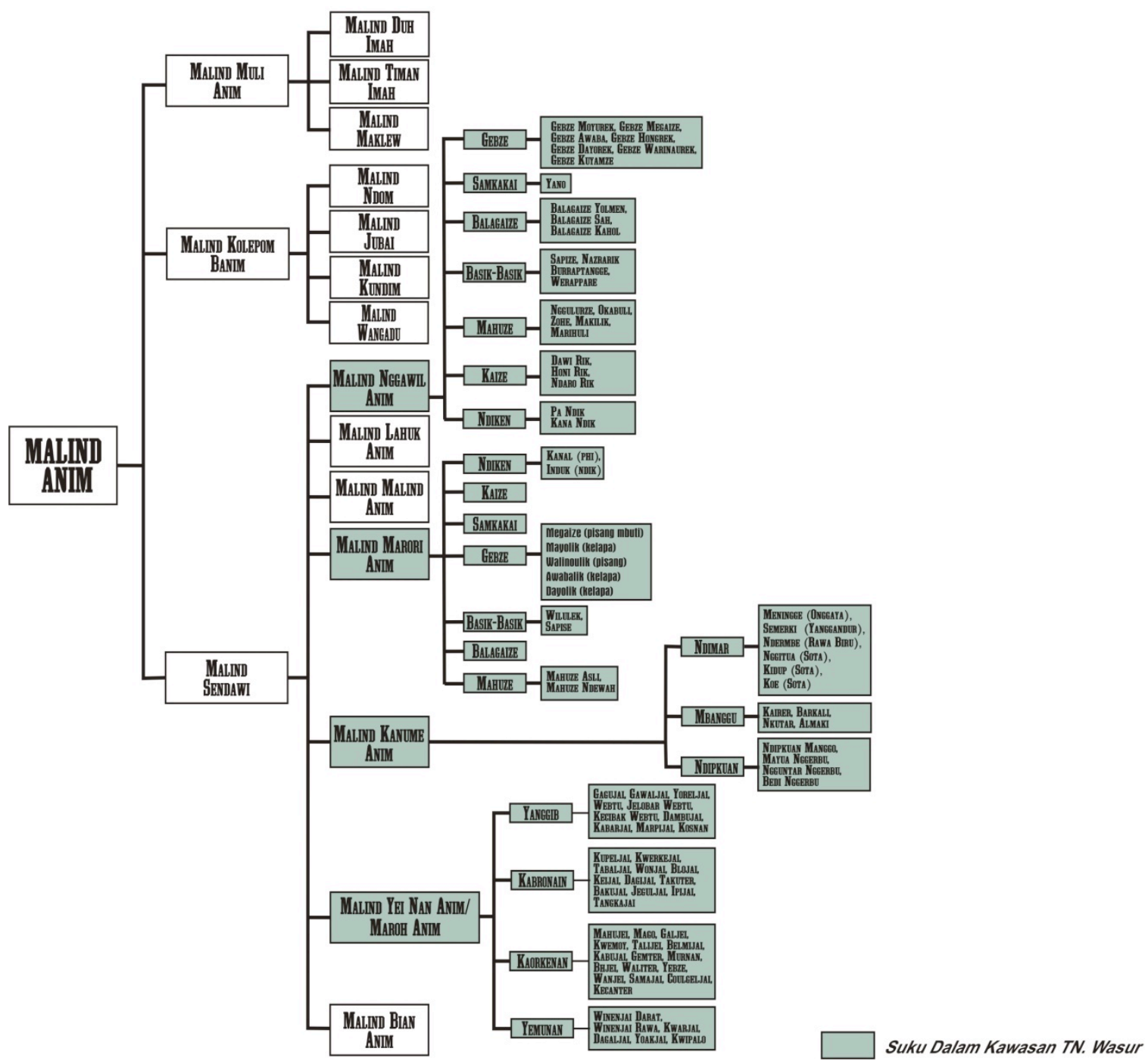

Figure 1-4. Cluster of sub-groups in Marind tribe, Papua. Source: Wasur National Park, Merauke, 2011. 


\section{Appendix 2.}

Tabel 1-1. The chemical compound using ethanol reagent, hecsana and chloroform from stem of Wati plant by tecnic GCMS (Gas Chromotography Mass Spectrometry).

\begin{tabular}{|c|c|c|}
\hline Hecsana & Chloroform & Methanol \\
\hline 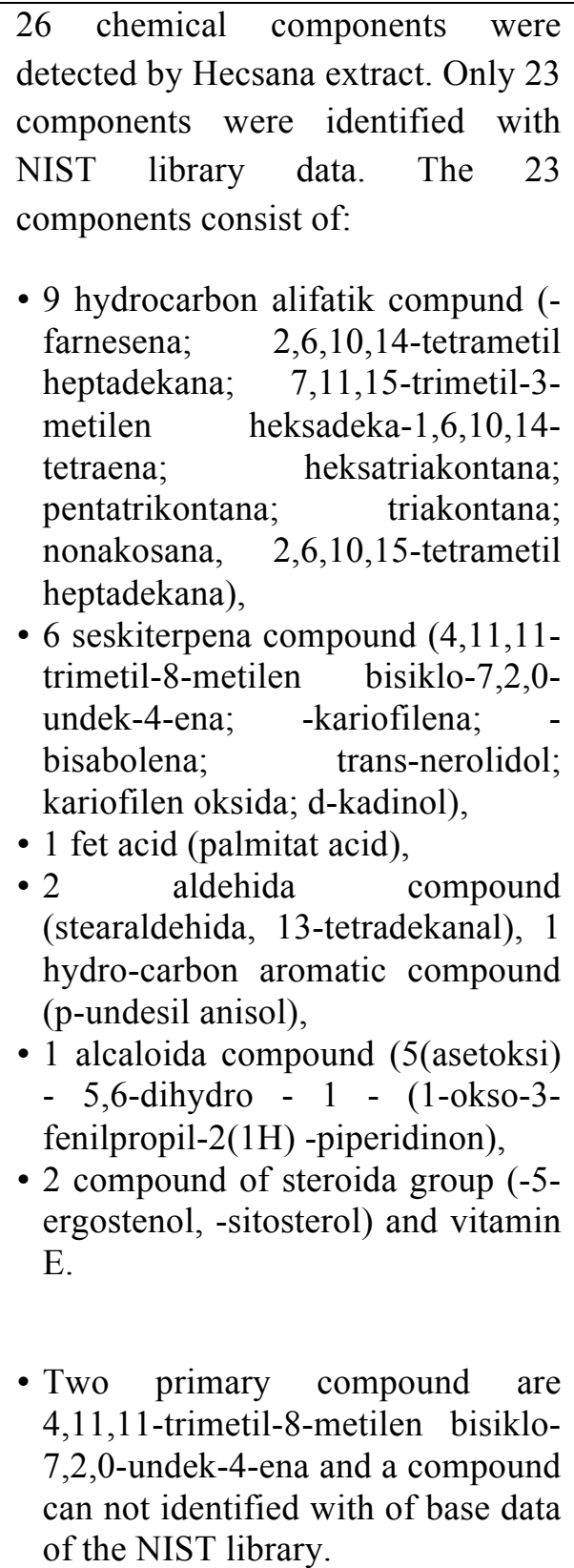 & $\begin{array}{l}\text { detected } 21 \text { chemical } \\
\text { components with: } \\
\text { - } 7 \text { primary component. It is 1- } \\
\text { (2-metoksibenzoil)-2- } \\
\text { (metoksimetil) pirolidina, p- } \\
\text { undesil anisol, yangonin and } \\
4 \text { compound can not } \\
\text { indentified with base data. } \\
\text { - Minor component consists of } \\
1 \text { hydrocarbon Ocsigen } \\
\text { compound (1,2-dimetoksi-1- } \\
\text { feniletana), derivat monoterpena } \\
1 \text { d } \\
\text { compound (7-metoksi-7-(p- } \\
\text { metoksifenil)-2-norbonena), } \\
3 \text { derivat fenol compound } \\
\text { (1(2-hydroksi-4,6- } \\
\text { dimetoksifenil)-3-(4- } \\
\text { hydroksifenil)-2-propen-1- } \\
\text { on; 2',4'-dihi-droksi-5'- } \\
\text { metoksi calkon; 2'-Hydroksi- } \\
\text { 4,4',6-trimetoksi calkon), } \\
2 \text { alcaloida compound (;acid } \\
\text { 5-benziloksi pirimidin-2- } \\
\text { carboksilat; 5-(asetiloksi)- } \\
5,6 \text {-dihidro-1-(1-okso-3- } \\
\text { fenil-propoksi)-2(1H)- } \\
\text { piridinon) } \\
2 \text { lakton compounds are } \\
\text { kawain and metistisin. }\end{array}$ & $\begin{array}{l}\text { detected: } \\
\text { - } 2 \text { primary components are } \\
\text { 2,3-dihidro-3,5- } \\
\text { dihydroksi-6-metil-4H- } \\
\text { piran-4-on and levulinat } \\
\text { acid. } \\
\text { - Beside it have other } \\
\text { component consist of } 4 \\
\text { alcohol compounds } \\
\text { (glisidol, 2-(Eteniloksi)- } \\
\text { etanol, furfuril alcohol, } \\
\text { hydroksimetilfurfurol), } \\
\text { - carboksilat acid } \\
\text { compound (asetat acid), } 2 \\
\text { alcaloida (5-metil-N- } \\
\text { metilhistamin, } \\
\text { piperidina carboksamida), } \\
\text { - } 2 \text { hydrocarbon Ocsigen } \\
\text { compound (4- } \\
\text { siklopentena-1,3-dion;; 5- } \\
\text { hidroksi-2- } \\
\text { (hidroksimetil)-4H-piran- } \\
\text { 4-on), } \\
\text { - hidrazona compound } \\
\text { (isobutiraldehida n- } \\
\text { propylhidrazona) and 2 } \\
\text { compound can not } \\
\text { identified. }\end{array}$ \\
\hline
\end{tabular}


Table 1-2. The chemical compound using ethanol reagent, hecsana and chloroform from leaf of Wati plant by tecnic GCMS (Gas Chromotography Mass Spectrometry).

\begin{tabular}{|c|c|c|c|c|}
\hline \multirow[b]{2}{*}{ no } & \multirow[t]{2}{*}{ Component } & \multicolumn{3}{|c|}{ Extract } \\
\hline & & Hexane & chloroform & methanol \\
\hline 1 & Isotetradecana & + & & \\
\hline 2 & Isokariofilena & + & & \\
\hline 3 & 2,6,10,14-Tetramethyl heptadecana & + & & \\
\hline 4 & 5-Oktadekena & + & & \\
\hline 5 & Palmitic acid & + & & \\
\hline 6 & 1-Hecsadecena & + & & \\
\hline 7 & $\rho$-Undesil anisole & + & + & \\
\hline 8 & Hecsatriacontana & + & & \\
\hline 9 & cis-Farnesol & + & & \\
\hline 10 & Pentatriacontana & + & & \\
\hline 11 & Eikosena & + & & \\
\hline 12 & Vitamin E & + & & \\
\hline 13 & $\gamma$-Sitosterol & + & & \\
\hline 14 & Stigmasterol & + & & \\
\hline 15 & Ergost-5-enol & + & & \\
\hline 16 & 1-Octadesina & & + & \\
\hline 17 & $\rho$-Metoxybenzil & & + & \\
\hline 18 & Acid 5-benziloksipirimidin-2-carboxylic & & + & \\
\hline 19 & $\begin{array}{l}\text { 5(Acetoxy)-5,6-dihydro-1(1-oxo-3- } \\
\text { fenilpropil)-2(1H)-piperidinon }\end{array}$ & & + & \\
\hline 20 & Kawain & & + & \\
\hline 21 & 3-(2-hydroxyfhenyl)-1,3-diphenyl-1-propanone & & + & \\
\hline 22 & Alternariol & & + & \\
\hline 23 & 2'-Hydroxy-4,4',6-trimetoxy kalkon & & + & \\
\hline 24 & Glisidol & & & + \\
\hline 25 & Acetat acid & & & + \\
\hline 26 & 2-(Eteniloksi)-ethanol & & & + \\
\hline 27 & 5-Methyl-N-methylhistamin & & & + \\
\hline 28 & 4-Cyclopentene-1,3-dione & & & + \\
\hline 29 & Furfuryl alcohol & & & + \\
\hline 30 & 4-Piperidina carboxamide & & & + \\
\hline 31 & Propylhidrazona isobutiraldehida & & & + \\
\hline 32 & 2,3-Dihydro-3,5-dihydroxy-6-methyl-4H-piran-4-or & & & + \\
\hline 33 & Hydroxymethilfurfurol & & & + \\
\hline 34 & 5-Hydroxy-2-(hydroxymethil)-4H-piran-4-on & & & + \\
\hline 35 & Levulinat acid & & & + \\
\hline
\end{tabular}




\section{Appendix 3.}

Tabel 1-4. Altitude of some towns by district, data 2009.

\begin{tabular}{|l|l|c|l|c|l|}
\hline \multicolumn{1}{|c|}{ District } & Capital of district & $\begin{array}{c}\text { Total area } \\
(\mathrm{km} 2)\end{array}$ & $\begin{array}{l}\text { Total of ratio } \\
(\%)\end{array}$ & $\begin{array}{c}\text { Altitude } \\
(\mathrm{m})\end{array}$ & $\begin{array}{l}\text { *Jarak tempuh } \\
\text { ke Ibukota } \\
\text { Kabupaten }\end{array}$ \\
\hline 01. Kimaam & Kimaam & 14.357 & 31.85 & $4-8$ & $145 \mathrm{Mil}$ \\
02. Tabonji & Tabonji & - & - & - & $148 \mathrm{Mil}$ \\
03. Waan & Waan & - & - & - & $140 \mathrm{Mil}$ \\
04. Ilwayab & Wanam & - & - & - & $149 \mathrm{Mil}$ \\
05. Okaba & Okaba & 9.684 & 21.49 & $4-40$ & $112 \mathrm{Mil}$ \\
06. Tubang & Yowied & - & - & - & $116 \mathrm{Km}$ \\
07. Ngguti & Po Epe & - & - & - & $120 \mathrm{Km}$ \\
08. Kaptel & Kaptel & - & - & - & $125 \mathrm{Km}$ \\
09. Kurik & Harapan Makmur & 5.598 & 12.42 & $5-30$ & $83 \mathrm{Km}$ \\
10. Animha & Wayau & - & - & - & $70 \mathrm{Km}$ \\
11. Malind & Kaiburse & - & - & - & $92 \mathrm{Km}$ \\
12. Merauke & Merauke & 2.113 & 4.69 & $3-25$ & - \\
13. Naukenjerai & Onggaya & - & - & - & $40 \mathrm{Km}$ \\
14. Semangga & Muram Sari & 760 & 1.69 & $4-20$ & $32 \mathrm{Km}$ \\
15. Tanah Miring & Hidup Baru & 466 & 1.03 & $6-25$ & $50 \mathrm{Km}$ \\
16. Jagebob & Kartini & 367 & 0.81 & $10-25$ & $99 \mathrm{Km}$ \\
17. Sota & Sota & 2.766 & 6.14 & $5-20$ & $76 \mathrm{Km}$ \\
18. Muting & Muting & 5.020 & 11.14 & $40-60$ & $247 \mathrm{Km}$ \\
19. Elikobel & Bupul & 2.367 & 5.25 & $22-55$ & $240 \mathrm{Km}$ \\
20. Ulilin & Kumaaf & 1.573 & 3.49 & $40-60$ & $244 \mathrm{Km}$ \\
\hline
\end{tabular}

Source : Transportation and Communication Service of Merauke Regency, 2009.

Table 1-5. Names of District, Capital District and Name of Villages/Wards of Merauke Regency.

\begin{tabular}{|c|c|c|c|}
\hline District & Capital of district & Villages/Wards & Total people \\
\hline (1) & (2) & (3) & (4) \\
\hline 1. Kimaam & Kimaam & $\begin{array}{l}\text { 1. Komolom } \\
\text { 2. Kumbis } \\
\text { 3. Kalilam } \\
\text { 4. Turiram } \\
\text { 5. Mambun } \\
\text { 6. Deka } \\
\text { 7. Woner } \\
\text { 8. Kiworo } \\
\text { 9. Kimaam } \\
\text { 10. Teri } \\
\text { 11. Sabudom }\end{array}$ & 4.804 \\
\hline 2. Tabonji & Tabonji & $\begin{array}{l}\text { 1. Tabonji } \\
\text { 2. Yamuka } \\
\text { 3. Iromoro } \\
\text { 4. Konjombando }\end{array}$ & 3.891 \\
\hline
\end{tabular}




\begin{tabular}{|c|c|c|c|}
\hline & & $\begin{array}{l}\text { 5. Yeraha } \\
\text { 6. Wanggambi } \\
\text { 7. Suam } \\
\text { 8. Bamol I } \\
\text { 9. Bamol II } \\
\end{array}$ & \\
\hline 3. Wan & Waan & $\begin{array}{l}\text { 1. Waan } \\
\text { 2. Konorau } \\
\text { 3. Tor } \\
\text { 4. Kladar } \\
\text { 5. Sabon } \\
\text { 6. Sibenda } \\
\text { 7. Kawe } \\
\text { 8. Wetau }\end{array}$ & 3.584 \\
\hline 4. ILyawab & Wanam & $\begin{array}{l}\text { 1. Wanam } \\
\text { 2. Wogekel } \\
\text { 3. Bibikem } \\
\text { 4. Padua } \\
\end{array}$ & 4.077 \\
\hline 5. Okaba & Okaba & $\begin{array}{l}\text { 1. Wambi } \\
\text { 2. Dufmiraf } \\
\text { 3. Iwol } \\
\text { 4. Makaling } \\
\text { 5. Okaba } \\
\text { 6. Alaku } \\
\text { 7. Alatep } \\
\text { 8. Sanggase }\end{array}$ & 4.660 \\
\hline 6. Tubang & Yowied & $\begin{array}{l}\text { 1. Wamal } \\
\text { 2. Dokib } \\
\text { 3. Yowied } \\
\text { 4. Dodalim } \\
\text { 5. Wodoyo } \\
\text { 6. Welbuti }\end{array}$ & 2.594 \\
\hline 7. Ngguti & Po Epe & $\begin{array}{l}\text { 1. Salam Epe } \\
\text { 2. Nakias } \\
\text { 3. Taga Epe } \\
\text { 4. Yawimu } \\
\text { 5. Po Epe }\end{array}$ & 2.054 \\
\hline 8. Kaptel & Kaptel & $\begin{array}{l}\text { 1. Kaptel } \\
\text { 2. Kanis Kobat } \\
\text { 3. Ihalik } \\
\text { 4. Kwemsid }\end{array}$ & 1.454 \\
\hline 9. Kurik & Harapan Makmur & $\begin{array}{l}\text { 1. Kurik } \\
\text { 2. Harapan Makmur } \\
\text { 3. Ivimahad } \\
\text { 4. Telaga Sari } \\
\text { 5. Salor Indah } \\
\text { 6. Sumber Rejeki } \\
\text { 7. Jaya Makmur } \\
\text { 8. Sumber Mulia } \\
\text { 9. Kaliki }\end{array}$ & 13.172 \\
\hline 10. Animha & Wayau & $\begin{array}{l}\text { 1. Koa } \\
\text { 2. Baad } \\
\text { 3. Wayao }\end{array}$ & 1.967 \\
\hline
\end{tabular}




\begin{tabular}{|c|c|c|c|}
\hline & & $\begin{array}{l}\text { 4. Senegi } \\
\text { 5. Kaisah }\end{array}$ & \\
\hline 11. Malind & Kaiburse & $\begin{array}{l}\text { 1. Kumbe } \\
\text { 2. Kaiburse } \\
\text { 3. Onggari } \\
\text { 4. Domande } \\
\text { 5. Rawa Sari } \\
\text { 6. Suka Maju } \\
\text { 7. Padang Raharja }\end{array}$ & 8.189 \\
\hline 12. Merauke & Merauke & $\begin{array}{l}\text { 1. Nasem } \\
\text { 2. Rimba Jaya } \\
\text { 3. Wasur } \\
\text { 4. Kelapa Lima } \\
\text { 5. Maro } \\
\text { 6. Mandala } \\
\text { 7. Samkai } \\
\text { 8. Karang Indah } \\
\text { 9. Bambu Pemali } \\
\text { 10. Seringgu Jaya }\end{array}$ & 70.002 \\
\hline 13. Naukenjerai & Onggaya & $\begin{array}{l}\text { 1. Kondo } \\
\text { 2. Tomerau } \\
\text { 3. Tomer } \\
\text { 4. Onggaya } \\
\text { 5. Kuler }\end{array}$ & 1.834 \\
\hline 14. Semangga & Muram Sari & $\begin{array}{l}\text { 1. Urum } \\
\text { 2. Waninggap } \\
\text { Nanggo } \\
\text { 3. Matara } \\
\text { 4. Muram Sari } \\
\text { 5. Semangga Jaya } \\
\text { 6. Sidomulyo } \\
\text { 7. Kuprik } \\
\text { 8. Kuper } \\
\text { 9. Marga Mulya } \\
\text { 10. Waninggap Kai }\end{array}$ & 11.432 \\
\hline 15. Tanah Miring & Hidup Baru & $\begin{array}{l}\text { 1. Soa } \\
\text { 2. Tambat } \\
\text { 3. Sumber Harapan } \\
\text { 4. Yasa Mulya } \\
\text { 5. Waninggap Say } \\
\text { 6. Waninggap Miraf } \\
\text { 7. Isanom Bias } \\
\text { 8. Yaba Maru } \\
\text { 9. Amun Kay } \\
\text { 10. Hidup Baru } \\
\text { 11. Sarmayam Indah } \\
\text { 12. Ngguti Bob } \\
\text { 13. Bersehati }\end{array}$ & 16.198 \\
\hline 16. Jagebob & Kartini & $\begin{array}{l}\text { 1. Kamno Sari } \\
\text { 2. Gurinda Jaya } \\
\text { 3. Jagebob Raya } \\
\text { 4. Mimi Baru }\end{array}$ & 8.471 \\
\hline
\end{tabular}




\begin{tabular}{|c|c|c|c|}
\hline & & $\begin{array}{l}\text { 5. Wenda Asri } \\
\text { 6. Angger Permegi } \\
\text { 7. Kartini } \\
\text { 8. Makarti Jaya } \\
\text { 9. Nalkin } \\
\text { 10. Poo } \\
\text { 11. Blandin Kakayu } \\
\text { 12. Yemunain Jaya } \\
\text { 13. Melin Megikar } \\
\text { 14. Obaat Throw }\end{array}$ & \\
\hline 17. Sota & Sota & $\begin{array}{l}\text { 1. Rawa Biru } \\
\text { 2. Yanggandur } \\
\text { 3. Sota } \\
\text { 4. Erambu } \\
\text { 5. Torai }\end{array}$ & 2.463 \\
\hline 18. Muting & Muting & $\begin{array}{l}\text { 1. Wan } \\
\text { 2. Selau } \\
\text { 3. Kolam } \\
\text { 4. Boha } \\
\text { 5. Pachas } \\
\text { 6. Muting } \\
\text { 7. Manwai Bop } \\
\text { 8. Apkap Makmur } \\
\text { 9. Andaito } \\
\text { 10. Enggol Jaya } \\
\text { 11. Sigabel Jaya } \\
\text { 12. Seed Agung }\end{array}$ & 5.606 \\
\hline 19. Elikobel & Bupul & $\begin{array}{l}\text { 1. Kweel } \\
\text { 2. Bupul } \\
\text { 3. Tanas } \\
\text { 4. Sipias } \\
\text { 5. Enggal Jaya } \\
\text { 6. Gerisar } \\
\text { 7. Metaat Makmur } \\
\text { 8. Bupul Indah } \\
\text { 9. Bouwer } \\
\text { 10. Bunggay } \\
\text { 11. Tof-Tof } \\
\text { 12. Bumun } \\
\end{array}$ & 4.402 \\
\hline 20. Ulilin & Kumaaf & $\begin{array}{l}\text { 1. Kumaaf } \\
\text { 2. Nggayu } \\
\text { 3. Kafyamke } \\
\text { 4. Belbelan } \\
\text { 5. Mandekman } \\
\text { 6. Rawahayu } \\
\text { 7. Kindiki } \\
\text { 8. Selil } \\
\text { 9. Kir - Ely } \\
\text { 10. Kandrakay } \\
\text { 11. Baidub }\end{array}$ & 4.535 \\
\hline Total $=20$ & & Total $=160$ & Total $=194.862$ \\
\hline
\end{tabular}

Source : Government Division of Regional Secretary of Merauke Regency, 2009. 


\section{Appendix 4. Questionnaire}

\section{INTERVIEW SHEET}

A. Informan data:

Village name

Hari/Tgl

Location

Status of Informan

B. List of question:

- Do you know about Wati plants? (Apakah saudara mengetahui tentang tumbuhan Wati?)

- Is variety of Wati? (Apakah wati bermacam-macam?)

- How many kinds of Wati? (Ada berapa macam Wati yang dikenal?)

- What is local name of kinds of Wati? (Apakah masing-masing macam Wati mempunyai nama lokal?)

- Is the wati plant growing, wild or planted by human? (Apakah tanaman Wati tumbuh liar atau ditanam oleh manusia?)

- Where the place to grow Wati plant? Dimana tempat tumbuhnya tanaman Wati (dikebun/dihutan)?

- Who are planted Wati plant? Siapa yang menanamnya?

- How to plant it? (Bagaimana cara menanamnya?)

- How to maintain it? (Bagaimana cara memelihara Wati?)

- What are the benefit of Wati? Apa manfaat dari Wati untuk?

- What are part of Wati plant used of people? (Bagian mana yang digunakan dari tanaman Wati?)

- How to harvest Wati plant? (Bagaimana panen tanaman Wati?)

- How to process of Wati plant? (Bagaimana mengolah Wati?)

- What other benefit from Wati plant? (Apa manfaat lain dari Wati?)

- Who are cultivate of Wati plant? (Siapa yang mengolah Wati?)

- Who are utilize of Wati plant? (Siapa yang memanfaatkan Wati?)

- Is there any reaction caused when using Wati plant? (Adakah reaksi yang di akibatkan bila menggunakan Wati?)

- Is there any effect? (Apakah ada efeknya?)

- How to neutralize the reaction? (Bagaimana menetralkan reaksi tersebut?)

- Is there any special treatment in the planting, maintaining of Wati plant? (Apakah ada perlakuan khusus dalam menanam, memelihara Wati?)

- Is there a separate beliefs about Wati plant? (Apakah ada kepercayaan tersendiri tentang Wati?) 
- What are the culture is still carried out using Wati plant? If not, why? (Apakah budaya yang menggunakan Wati masih tetap dilaksanakan? Kalau tidak, mengapa?)

- Is a culture that uses Wati plant need to be preserved? (Apakah budaya yang menggunakan Wati perlu dilestarikan?)

- Where they get this knowledge? (Dari mana mereka mendapatkan pengetahuan ini?)

- Why Wati plant used in all ritual ceremony, why not other plant? (Mengapah Wati yang dipakai dalam berbagai upacara adat, mengapa bukan tumbuhan lain?) 


\section{Appendix 5.}

Table 3-2. Identification of parts of Wati plant by Marind Swamp (Marind Rawa / Marind bob).

\begin{tabular}{|c|c|c|c|c|}
\hline \multirow{2}{*}{$\begin{array}{l}\text { Bagian } \\
\text { tanaman }\end{array}$} & \multicolumn{4}{|c|}{ Kampung/Desa } \\
\hline & Bamol 1 & Bamol 2 & Iromoro & Woner \\
\hline Root & kiya & kiya & kuere & kiye \\
\hline Stem & kaburu & kaburu & tuandua & do \\
\hline Branch & tiye & tiye & yawe & tiye \\
\hline Internode & kaburu & kaburu & tuandua & paybru \\
\hline Node & kaburu & kaburu & mboke & pimey \\
\hline Bud's nodes & kaburu & kaburu & anambo & awu \\
\hline Bud & me & me & bere & buh \\
\hline $\begin{array}{l}\text { Branch's } \\
\text { bark }\end{array}$ & kerara & kerara & kwika & krakra \\
\hline Leaves & cuku & cuku & kebe & cuku \\
\hline Stalk of leaf & yawei & yawei & nabo & mapu \\
\hline Bone of leaf & wayi & wayi & nduka & uwah \\
\hline Fruit & ta & ta & tawi & ta \\
\hline Sheath & yawei & yawei & nabo & mapu \\
\hline Bud & muyuku & muyuku & umoto & muru \\
\hline
\end{tabular}




\title{
CURRICULUM VITAE
}

\author{
Konstantina Maria Brigita Kameubun \\ Born in Merauke, 22 February 1976 \\ Job Category : Lecturer in Biology Education Department, Teacher training and \\ education faculty, University of Cendrawasih, Jayapura, Papua, Indonesia, from \\ December 2001 - Now \\ Address: Kampus UNCEN Baru Waena, Jayapura, Papua, Indonesia \\ Contact Information \\ Email.brigitabio@yahoo.co.id / konstantina.kameubun@yahoo.co.id
}

Education
Georg-August University of Goettingen, Germany
Dr rer.nat., Johann-Friedrich-Blumenbach-Institut
für Zoologie und Anthropologie, Abt. Naturschutzbiologie, (früher: Zentrum für Naturschutz),

November 2013

Dissertation title: Indigenous knowledge, morphological variation and genetic diversity of Kava (Piper methysticum Forst.) in Merauke, Papua, Indonesia

Advisor: Prof. Dr. Michael Muehlenberg, Prof.h.c

Committee members: Prof. Dr. Michael Muehlenberg, Prof.h.c, Prof. Dr. Reiner Finkeldey,

\section{Bogor Agricultural University, Bogor, Indonesia}

M.Si, Plant Taxonomy, Mathematic and science faculty, Magna cum laude, 29 December 2003.

Thesis title: Aspek botani dan etnobotani Wati (Piper methysticum Forst.) dalam kehidupan suku Marind kabupaten Merauke, Papua

Supervisors: Prof. Dr. Ir. Edy Guhardja, M.Sc, Dr. Eko Baroto Walujo.

\section{Cenderawasih University, Jayapura, Papua, Indonesia}

S.Pd, Biology Education, Teacher training and education faculty, Magna cum laude, 29 April 2000.

Thesis title: Tree diversity in the lowland rainforest in Yemang village, Yongsu Dosoyo, Depapre district, Jayapura regency, Papua, Indonesia (Keanekaragaman Jenis Pohon Hutan Hujan Tropis Dataran Rendah di Desa Yemang, Yongsu Dosoyo Kecamatan Depapre Kabupaten Jayapura - Papua)

Supervisor: Drs. Basa T. Rumahorbo, M.Si, Dra. Verena Agustini, M.Sc 


\section{RESEARCH AND WORK EXPERIENCES}

Centre for Nature Conservation, Johann-Friedrich-Blumenbach-Institut für Zoologie und Anthropologie, Abt. Naturschutzbiologie, (früher: Zentrum für Naturschutz)

Graduate research scientist $2009-2013$

Teaching in Biology Education Program, Teacher Training and Education Faculty, Cenderawasih University

Teach courses:

Plant Morphology, Advance Botany, Ethno Botany, Economic Botany 2004-2008

Practicum on the field 2004-2008

Supervisor: Thesis of Bachelor student 2004-2008

Bogor Agriculture University, Plant Taxonomy

Graduate research scientist $2002-2003$

Cenderawasih University, Biology Education

Graduate research scientist

$1999-2000$

\section{Research projects}

1. Kameubun, K.M.B, Rosania Rehiara, Frans Dominggus. Etnobotani, koleksi dan analisis komponen dan komposisi kimia penyusun minyak atsiri serta uji sifat antibakteri Piper sp (Piper bumbu barapen) asli Wamena, Papua. Sponsor by Hibah bersaing DIKTI. 2013.

2. Rosania Rehiara, Konstantina M.B Kameubun, Frans Dominggus. Uji antibakteri etanol kultivar-kultivar tanaman Wati (Piper methysticum) asal Merauke, Papua. Sponsor by Hibah fundamental DIKTI. 2013.

3. Kameubun, K.M.B. Inventarisasi dan etnobotani Piper spp di Kampung Yenwapnur Kabupaten Raja Ampat. Sponsor by Kerjasama UNCEN- Unit Goettingen, German. 2008.

4. Simbiak, M dan Kameubun, K.M.B. Keanekaragaman dan Pemanfaatan Piper spp (Sirih-sirihan) Masyarakat Adat Di Cagar Alam Pegunungan Cycloop Jayapura, Papua. Sponsor by DIKTI Dosen Muda, 2006.

5. Kameubun, K.M.B, Lili Rusly Bekti dan Yohanis Ngili. Eksplorasi Kultivar, Etnobotani, dan Analisis Kandungan Senyawa Kimia serta Sifat Antibakteri Dari Tumbuhan Wati (Piper methysticum Forst.) Asal Merauke - Papua. Sponsor by Hibah bersaing DIKTI. 2006.

6. Tanjung, R.H.R, Konstantina M.B Kameubun, Suharno. Keragaman Nepenthes dan Begonia di Kampus UNCEN dan wilayah kelurahan Waena, Jayapura-Papua. Laporan UNCEN, Sponsor by kerjasama UNCEN-UPNG (Unit Papua New Guinea) 2005.

7. Kameubun, K.M.B. Keanekaragaman Jenis Pohon Di Hutan Lindung UNCEN, Waena - Jayapura, Papua. Sponsor by WWF Papua Region. 1999. 


\section{PUBLICATIONS}

Book:

1. Konstantina M.B Kameubun. (2011). Flora dan Fauna di Papua. "Tumbuhan". Penerbit: Kerja sama Conservation International dan Dinas pendidikan, pemuda \& olah raga provinsi Papua

Bulletin :

1. Yance de Fretes, K.M.B. Kameubun, Ismail Rahman, Julius Nugroho, Elisa Wally, Herman Remetwa, Marthen Kabiay, Ketut G. Suartana, Basa T Rumahorbo (2002). Plant diversity in lowland forests of the Yongsu area, Papua, Indonesia. RAP (Rapid Assessment Program) Bulletin of Biological, Assessment 25.A Biodiversity Assessment of Yongsu - Cyclops Mountains and the Southern Mamberamo Basin, Papua, Indonesia. Editor Stephen J. Richards and Suer Suryadi. Conservation International, Washington DC, USA.

Journals:

1. Dwi Haryanto, Tanjung, R.H.R, Konstantina Kameubun (2006). Pemanfaatan tumbuhan obat masyarakat Marind yang bermukim di taman nasional Wasur, Merauke. Jurnal Biologi Papua, Volume 1, nomor 2, hal 58-64, ISSN: 2086-3314 Oktober 2009.

2. Konstantina M.B. Kameubun, Eko Baroto Walujo (2004). Local knowledge of Marind tribe, Papua versus botanical saintific of tanaman wati (Piper methysticum Forst.). Sisipan Biodiversitas Journal ISSN: 1412-033X, Volume 5, Nomor 1, Januari 2004

\section{Presentations:}

1. Konstantina M.B Kameubun, Deonisia M.P Kameubun, Oliva M.A Kameubun, Yohanis Ngili (2012). Budaya suku Marind dan konservasi tanaman Wati (Piper methysticum Forst.) di Merauke Papua Selatan. Prossiding: Seminar Ilmiah SeEropa, Berkarya Untuk Indonesia. ISSN 9-772302690005. Vol I/no 1/2012. Wageningen, Netherland.

2. Tanjung, R.H.R, Dwi Haryanto, Konstantina Kameubun (2006). Inventory study on medicinal plants of Marind people at Wasur National Park, Merauke, Papua Province. Prossiding: 8 th New Guinea Biology Conference, September 26 th -28 th 2006. Papua New Guinea (PNG).

3. Konstantina M.B Kameubun (2002). Indigenous knowledge Wati plant by Marind ethnis. Seminar Pengelolaan Keanekaragaman Hayati Berdasarkan Indigenous Knowledge Etnik Papua. Organized by Program kerja sama Northern Territory University dengan FMIPA UNCEN. UNCEN, 23-24 Agustus 2002. 
Abstract and Posters:

1. Konstantina Maria Brigita Kameubun, Kathleen Prinz, Yohanis Ngili, Reiner Finkeldey, Michael M"uhlenberg (2012). Indigenous Knowledge for Classification and Utilisation of Wati (Piper Methysticum Forst.) in Marind Tribe of Merauke Regency, Southern Papua. Prossiding: "Resilience of agricultural systems against crisis" Tropentag, September 19-21, 2012, Goettingen.

2. Kameubun, Konstantina.M.B., and Michael Muehlenberg (2010). Ethnobotany of Piper spp and species diversity of the Piper plants in Papua. Prossiding: 1st International Biodiversity Conference on Sustainable Development in The Land of Papua, Jayapura 8-11 November 2010

3. Kameubun, K.M.B, Yance de Fretes and Michael Muehlenberg (2010). Tree richness and forest structure of the forests around Yongsu Dosoyo, Jayapura, Papua, Indonesia. Prossiding: "World Food System — A Contribution from Europe" Tropentag, September 14-16, 2010, Zurich, Switzerland.

4. Tanjung, R.H.R, Konstantina Kameubun, Suharno (2008). Diversity of Nepenthes species in Waena Jayapura, Papua. Prossiding: 9 th New Guinea Biology Conference, October 26 th -28 th 2007. Jayapura, Papua, Indonesia.

5. Agustina Maro, Konstantina Kameubun dan Maikel Simbiak (2007). Ethnobotany and inventarisation Daun Gatal (Urticaceae) in Ormu village, Jayapura, Papua. Prossiding: 9 th New Guinea Biology Conference, October 26 th -28 th 2007. Jayapura, Papua, Indonesia.

6. Jimmy G.M. Fitowin, Kosntantina Kameubun, Basa T. Rumahorbo (2006). Ethnobotanical study of Pra Kepey (Dianella nemorosa) conducted in Tablasupa village, Jayapura, Papua. Prossiding: 8 th New Guinea Biology Conference, September 26 th -28 th 2006. Papua New Guinea (PNG).

\section{Other publications:}

1. Kameubun, K.M.B; Rosania Rehiara, Frans Deminggus (2013). Etnobotani, koleksi dan analisis komponen dan komposisi kimia penyusun minyak atsiri serta uji sifat antibakteri Piper sp (Piper bumbu barapen) asal Wamena, Papua. Laporan Penelitian UNCEN- Hibah bersaing DIKTI.

2. Doloksaribu Florida, Jukwati, Kameubun, K.M.B (2013). Pengembangan model dan modul perkuliahan untuk meningkatkan keterampilan research thinking Brainstorming mahasiswa berlatar ilmu Kimia-Biologi dalam menggali sumber daya alam Papua. Laporan Penelitian UNCEN- Hibah bersaing DIKTI. 
3. Rosania Rehiara, Frans Deminggus, Kameubun, K.M.B (2013). Uji antibakteri metanol kultivar-kultivar tanaman Wati (Piper methysticum Forst.) asal Merauke, Papua. Laporan Penelitian UNCEN- Fundamental DIKTI

4. Kameubun, K.M.B. (2008). Inventarisasi dan etnobotani Piper spp di Kampung Yenwapnur Kabupaten Raja Ampat. Laporan Penelitian UNCEN, Kerjasama UNCEN- Unit Goettingen, German (2008).

5. Simbiak, M dan Kameubun, K.M.B. 2007. Keanekaragaman dan Pemanfaatan Piper spp (Sirih-sirihan) Masyarakat Adat di Cagar Alam Pegunungan Cycloop Jayapura, Papua. Laporan Penelitian Dosen Muda. Direktorat Jenderal Pendidikan Tinggi, Departemen Pendidikan Nasional

6. Kameubun, K.M.B, Lili Rusly Bekti dan Yohanis Ngili (2007). Eksplorasi dan Etnobotani Kultivar-kultivar Wati (Piper methysticum Forst.) antar kelompok suku Marind di Kabupaten Merauke. Laporan Penelitian UNCEN, Hibah bersaing DIKTI.

7. Tanjung, R.H.R, Konstantina Kameubun, Suharno (2005). Keragaman Nepenthes dan Begonia di Kampus UNCEN dan wilayah kelurahan Waena, Jayapura-Papua. Laporan Penelitian UNCEN, kerjasama UNCEN-UPNG (Unit Papua New Guinea).

\section{Professional Training/Certification}

1. Photography for Beginner. Organized by Indonesian Students Association Goettingen, Germany, $21^{\text {st }}-23^{\text {rd }}$ April 2011.

2. Microsatelite Marker (Genetic laboratorium). Organized by Forest Genetics and Forest Tree Breeding, Georg-August University of Goettingen, Germany

3. Penyusunan Bahan Ajar Online Dengan Animasi. Organized by FMIPA UNCEN dan Forum Kerjasama Sepuluh Universitas, Jayapura 26-30 Juni 2006.

4. Metodologi Pengabdian Kepada Masyarakat. Organized by Lembaga Pengabdian Kepada Masyarakat, Subdin Pendidikan Tinggi-Dinas Pendidikan dan Pengajaran Provinsi Papua. Jayapura, 2006.

5. Lokakarya, Pengembangan Strategi Dan Metode Pembelajaran Biologi Dasar. Organized by Program Peningkatan Relevansi Program Due-Like Batch III TPB Tahun 2005. Jayapura 24 September 2005.

6. Seminar Lokakarya, Kurikulum Berbasis Kompetensi (KBK). Organized by Program Studi Pendidikan Geografi Jurusan Pendidikan dan Ilmu Pengetahuan Sosial, Fakultas Keguruan dan Ilmu Pendidikan Universitas Cenderawasih. Jayapura 9-11 Mei 2005. 
7. Lokakarya, Penulisan Modul Mata Kuliah dan Artikel Pada Jurnal Ilmiah. Organized by Fakultas Keguruan Dan Ilmu Pendidikan Universitas Cenderawasih. Jayapura, 14-15 Februari 2005.

8. Lokakarya"Metode Penelitian Etnobiologi". Organized by Program Kerjasama Universitas Cenderawasih dengan George August University of Goettingen Germany- NTU. Jayapura 15 Mei 2004.

9. Lokakarya Taksonomi, Kemampuan Pelayanan Taksonomi Dan Kebutuhan Pengguna Dalam Informasi Taksonomi. Organized by Kelompok Kerja Inisiatif Nasional Taksonomi Indonesia, Kementerian Lingkungan Hidup, Yayasan Naturindo Bogor dan PUSLIT Biologi - LIPI, 13 Desember 2003.

10. International Workshop on Annonaceae. Organized by Bogor Agriculture University, Bogor, 2-8 September 2001

11. Rapid Assessment Program. A Biodiversity Assessment of Yongsu-Cyclops Montains and the Southern Mamberamo Basin, Papua, Indonesia 2000. Organized by Conservation International - Indonesia. Jayapura-Yongsu-the Southern Mamberamo Basin, Papua, Indonesia 2000.

12. Training, Research Design \& Proposal Writing. Organized by Conservation International - Indonesia. Jayapura-Yongsu Desoyo, 3-15 July 2000

13. Training, Basic Skill on Biodiversity Inventori. Organized by Conservation International Indonesia Program, Cipta Citra Lestari Indonesia Foundation. Jayapura, 6-25 September 1999.

\section{AWARDS, GRANTS, FELLOWSHIP, SCHOLARSHIP}

1. Directorate General of Higher Education (DGHE) of Indonesia. Two (2) times of Research Grant of Hibah Bersaing (2013)

2. Directorate General of Higher Education (DGHE) of Indonesia. Research Grant of Fundamental Research (2013)

3. Directorate General of Higher Education (DGHE) of Indonesia. Scholarship (2008-2012)

4. Directorate General of Higher Education (DGHE) of Indonesia. Research Grant Hibah Bersaing (2006)

5. Directorate General of Higher Education (DGHE) of Indonesia. Research Grant Dosen Muda (2006)

6. Papua Province Goverment, Papua. Scholarship (2001-2003)

7. WWF regional Papua. Grant research (1999)

8. Education Ministry of Indonesia. Scholarship (1998-2000) 


\section{LANGUAGES}

Foreign: $\quad$ English (Fluent), German (Basic speaking and understanding)

Indonesia (Kei)

\section{PERSONAL}

Nationality: Indonesianese

Gender: Female

RECREATIONAL INTERESTS Basketball, Badminton, Disco, Traveling

Goettingen, 8 November 2013

Konstantina Maria Brigita Kameubun 